\title{
The influence of construction materials on life-cycle energy use and carbon dioxide emissions of medium size commercial buildings
}

Nicolas Perez Fernandez

\author{
July 2008
}





\section{Acknowledgments}

Many thanks to the Primary Supervisor of this research project, Professor George Baird, who was always available to give valuable feedback and guidance. Many thanks to the Co-supervisor of this research project, Professor Andrew Buchanan, whose enthusiasm, interest and valuable feedback and guidance made this research project possible.

The author would like acknowledge the Department of Civil Engineering of the University of Canterbury, who provided financial assistance for this project, and the National Energy Research Institute who provided additional financial assistance.

The author is also very thankful to the many other people who made this study possible, through their particular interest in the work and their willingness to provide helpful information and support. I would especially like to thank those who took the time to assist in this research: Andrew Alcorn from the School of Architecture of Victoria University, Patrick Arnold from the eCube Building Workshop, Stephen John and Tobias Smith from the Department of Civil Engineering of University of Canterbury, Morten Gjerde from the School of Architecture of Victoria University, Barbara Nebel and Simon Love from Forest Research, Phil Schumacher and Ross Davidson from Davis and Langdon, Nick Courtney from Courtney Architects, Mathew Gray from Powell Fenwick, Duan Zhao and Yue Jia from the School of Architecture of Victoria University, Huantian Xiao from Steel Construction New Zealand, and Sam Curtis from the School of Architecture of Victoria University.

Finally, I would like to make a special acknowledgement to my wife, Francisca whose love, company and constant support gave me the strength to pursue this research to what I hope is a worthwhile conclusion.

I dedicate this thesis to my Wife and to my new born son, Renato. 


\section{Preface}

This thesis was submitted in fulfilment of the requirements for the degree of Master of Building Science at the School of Architecture, Victoria University of Wellington.

Author:

Nicolas Perez Fernandez

School of Architecture

Victoria University of Wellington

Email: nperezarq@gmail.com

Primary Supervisor:

Dr. George Baird

Professor of Building Science

School of Architecture

Victoria University of Wellington

Email: george.baird@vuw.ac.nz

Co-supervisor:

Dr Andrew Buchanan

Professor of Timber Structure

University of Canterbury

College of Engineering

Email: Andy.Buchanan@canterbury.ac.nz 


\section{Table of contents}

1 INTRODUCTION:

1.1 Buildings' environmental implications___ 4

1.1.1 New Zealand___ 5

1.2 Buildings' materials _ 5

1.2.1 Life-cycle assessment___ 6

1.3 Problem statement__ 7

1.4 Scope__ 7

1.5 Research questions: __ 8

1.6 Key definitions: _ 9

1.7 Research overview___ 11

2 LITERATURE REVIEW: _ 13

2.1 Office buildings' life-cycle energy consumption and $\mathrm{CO}_{2}$ emissions components _ 14

2.2 Operating energy consumption and $\mathrm{CO}_{2}$ emissions 15

2.3 Embodied energy and embodied $\mathrm{CO}_{2}$ emissions 17

2.3.1 Initial embodied energy and initial embodied $\mathrm{CO}_{2}$ emissions __ 17

2.3.1.1 Comparisons of concrete, timber and steel case studies ___ 19

2.3.2 Summary of initial embodied energy and initial embodied $\mathrm{CO}_{2}$ emissions __ 20

2.3.3 Recurrent embodied energy and recurrent embodied $\mathrm{CO}_{2}$ emissions accounted for in buildings 21

2.4 Structure and finishes embodied energy and embodied $\mathrm{CO}_{2}$ emissions 23

2.4.1 Structure and finishes embodied energy in a concrete, steel and timber building ___ 24

2.5 Demolition energy consumption and demolition $\mathrm{CO}_{2}$ emissions _ 26

2.6 Embodied energy and $\mathrm{CO}_{2}$ emissions in 'low-energy' buildings__ 27

2.7 Assessment of the differences between concrete, steel and timber buildings _ 28 
3.1 Building design _ 32

3.1.1 Alternative buildings __ 34

3.2 Building description:__ 35

3.2.1 Concrete building:__ 38

3.2.2 Steel building: __ 39

3.2.3 Timber and Timber-Plus buildings: ___ 41

3.2.4 Timber building finishes____ 42

3.2.5 Common finishes used in a Timber-plus building ___ 43

3.3 Assessment of buildings' operating energy consumption and $\mathrm{CO}_{2}$ emissions: __ 45

3.3.1 Simulation method: _ 47

3.3.1.1 HVAC_48 48

3.3.1.2 Schedule __ 48

3.3.1.3 Buildings thermal envelope description ___ 49

3.3.2 Floor areas for simulation __ 51

3.3.3 Energy sources and $\mathrm{CO}_{2}$ factors___ 51

3.4 Assessment of buildings' embodied energy and embodied $\mathrm{CO}_{2}$ emissions _ 53

3.4.1 LCA scope in this research __ 53

3.4.2 Measurement of quantities __ 54

3.4.2.1 Recurrent embodied energy __ 55

3.5 Embodied energy and embodied $\mathrm{CO}_{2}$ data used__ 56

3.5.1 Overview of the differences between the Alcorn and the GaBi data ___ 57

3.5.1.1 Country/region related differences___ 57

3.5.1.2 Differences in inventory analysis __ 57

3.5.1.3 Impact assessment categories __ 58

3.5.1.4 Negative $\mathrm{CO}_{2}$ coefficients for timber in Alcorn and not in $\mathrm{GaBi}$ ___ 58

3.6 Summary of methodology _ 59

4 RESULTS_ 61

4.1 Life-cycle energy consumption 62

4.1.1 Operating energy___ 62

4.1.1.1 Operating energy consumption benchmarks___ 63

4.1.1.2 Operating energy segregated in end-uses: ___ 66

4.1.1.3 Heating and cooling end-uses ___ 69

4.1.1.4 Comparison between the concrete and timber buildings as examples of a high and low thermal mass buildings respectively ___ 71

4.1.1.5 Life-cycle operating energy use ___ 73

4.1.2 Embodied energy __ 74

4.1.2.1 Ranking of building's total embodied energy ___ 76

4.1.2.2 Buildings components' initial embodied energy___ 78

4.1.3 Total life-cycle energy consumption __ 80

4.1.3.1 Ranking of buildings' life-cycle energy use ___ 81 
4.2.1 Operating $\mathrm{CO}_{2}$ emissions ___ 84

4.2.1.1 Operating $\mathrm{CO}_{2}$ emissions segregated into end-uses____ 86

4.2.1.2 Life-cycle operating $\mathrm{CO}_{2}$ emissions____ 88

4.2.2 Embodied $\mathrm{CO}_{2}$ emissions ___ 89

4.2.2.1 Ranking of buildings' total embodied $\mathrm{CO}_{2}$

4.2.2.2 The total embodied $\mathrm{CO}_{2}$ emissions of building components ___ 91

4.2.3 Total Life-Cycle $\mathrm{CO}_{2}$ Emissions ___ 95

4.2.3.1 Ranking of buildings' life-cycle $\mathrm{CO}_{2}$ emissions ___ 96

4.2.3.2 Summary of the life-cycle $\mathrm{CO}_{2}$ emissions ___ 99

5 DISCUSSION_ 101

5.1 Life-cycle operating energy consumption and $\mathrm{CO}_{2}$ emissions _ 102

5.1.1 Operating energy consumption end-uses ___ 103

5.1.2 Operating $\mathrm{CO}_{2}$ emission end-uses __ 104

5.2 Embodied energy and $\mathrm{CO}_{2}$ emissions _ 106

5.2.1 GaBi total embodied energy and $\mathrm{CO}_{2}$ emissions _ 106

5.2.2 Alcorn total embodied energy and $\mathrm{CO}_{2}$ emissions __ 108

5.2.3 Total embodied energy and $\mathrm{CO}_{2}$ emissions summary of the two different sets of coefficients_ 109

5.3 Buildings component's total embodied energy and total embodied $\mathrm{CO}_{2}$ emissions ___ 110

5.3.1 Change in building components to reduce the total embodied energy and $\mathrm{CO}_{2} \ldots 112$

5.4 Total life-cycle energy consumption and $\mathrm{CO}_{2}$ emissions___ 118

5.4.1 Alcorn life-cycle energy consumption and $\mathrm{CO}_{2}$ emissions 120

5.4.2 GaBi life-cycle energy consumption and $\mathrm{CO}_{2}$ emissions _ـ 120

5.4.3 Summary of the life-cycle energy consumption and $\mathrm{CO}_{2}$ emissions ___ 121

6 CONCLUSIONS_ 124

6.1 Future research 132

REFERENCES _ 134

APPENDIXES: $\quad 139$

A. BACKGROUND. $\quad 139$

A.1 Initial embodied energy and $\mathrm{CO}_{2}$ emissions__ 139

A.2 Total initial embodied energy subdivided by components: 140

A.3 Recurring embodied energy and $\mathrm{CO}_{2} \ldots 141$

B. METHODOLOGY___ 142

B.1 Operating energy__ 142 
B.2 Recurrent energy

B.3 Embodied energy___ 144

C. RESULTS 146

C.1 Operating energy consumption 146

C.2 Comparison between the concrete and timber buildings as examples of a high and low thermal mass buildings respectively _ـ 147

C.3 Operating $\mathrm{CO}_{2}$ emissions _ 151

D. DISCUSSION 152

D.1 Total Life-Cycle Energy Consumption and $\mathrm{CO}_{2}$ emissions _ 152 


\section{List of Tables:}

Table 2.1: Summary of operational energy and $\mathrm{CO}_{2}$ emissions of the buildings analysed by the papers in this literature review 16

Table 2.2: Summary of total initial embodied energy for each of the cases in the literature review. 18

Table 2.3: Summary of total initial embodied $\mathrm{CO}_{2}$ emissions from cases in the literature review. 19

Table 2.4: Summary of recurring energy and $\mathrm{CO}_{2}$ emissions of the buildings analysed in the previous section.

Table 2.5: summary of initial embodied energy subdivided by structural and non-structural components, data from cases in the previous section. 23

Table 2.6: The U.S, Advisory Council on historic preservation energy use in demolition (Cole \& Kernan, 1996).

Table 2.7: Assumption of energy in operation reduction and its weight in life-cycle energy use 27

Table 3.1: Simulation input values 47

Table 3.2: Schedule for operating energy simulation 48

Table 3.3: Calculation of the Net Usable Area for the analysis of results 51

Table 3.4: Concrete building schedule from Quantity Surveyor 54

Table 3.5: Calculation scheme for operating and embodied energy and $\mathrm{CO}_{2}$ emissions, as used in this thesis. 59

Table 4.1: Operating energy annual results 63

Table 4.2: Property Council of New Zealand, 2000 Energy Use Index. 64

Table 4.3: Office buildings energy end-use distributions in New Zealand (Bishop, 1992). 67

Table 4.4: Office buildings energy end-use distribution in the UK (CIBSE, 2006) 67

Table 4.5: Concrete and timber buildings' total design cooling requirement and total design heat loss. 71 Table 4.6: Energy consumed in operations, annual and 60 year life-cycle consumption in GJ 73 Table 4.7: Total embodied energy segregated into initial and recurrent embodied energy using coefficients of embodied energy from two different sources (Gabi software and Alcorn (2003)). 76

Table 4.8: Buildings' items in the schedule of materials organised into five main buildings components. 78 Table 4.9: Total 60 year life-cycle energy use, including 60 years of operating energy consumption, total embodied energy (initial embodied and recurrent embodied energy) using embodied energy coefficients based on the $\mathrm{GaBi}$ and the Alcorn databases. 80

Table 4.10: Annual energy use and $\mathrm{CO}_{2}$ emissions in operations 85

Table 4.11: Annual and life-cycle operating $\mathrm{CO}_{2}$ emissions 88 Table 4.12: Total embodied $\mathrm{CO}_{2}$ emissions segregated into initial and recurrent embodied $\mathrm{CO}_{2}$ emissions using data for embodied $\mathrm{CO}_{2}$ from two different sources: the $\mathrm{GaBi}$ and the Alcorn (2003) databases. 89 Table 4.13: Total 60 year life-cycle $\mathrm{CO}_{2}$ emissions, including 60 years of $\mathrm{CO}_{2}$ emissions in operation, and total embodied energy (initial embodied $\mathrm{CO}_{2}$ emissions plus recurrent embodied $\mathrm{CO}_{2}$ emissions) using embodied $\mathrm{CO}_{2}$ coefficients based on the $\mathrm{GaBi}$ and Alcorn databases. 95 Table 5.1: Annual and life-cycle (60 year) operating energy consumption and operating $\mathrm{CO}_{2}$ emissions _ 102 Table 5.2: Embodied energy and $\mathrm{CO}_{2}$ emissions using $\mathrm{GaBi}$ coefficients 106 Table 5.3: Embodied energy and $\mathrm{CO}_{2}$ emissions using Alcorn coefficients. 108 
Table 5.4: Shows for the concrete, steel and timber-plus buildings, the buildings components that remain original and those that will be replaced by timber-plus building components. 112

Table 6.1: Case study buildings, annual operating energy. 126

Table 6.2: Case study buildings, annual operating $\mathrm{CO}_{2}$ emissions. 127

Table 6.3: Case study buildings, total embodied energy. 127

Table 6.4: Case study buildings, total embodied $\mathrm{CO}_{2}$ emissions. 128

Table 6.5: Comparison of embodied energy and life-cycle energy consumption 128

Table 6.6: Comparison of embodied $\mathrm{CO}_{2}$ and life-cycle $\mathrm{CO}_{2}$ emissions. 129

Table A.1: Case study final embodied energy by square meter (Treloar, Fay, llozor, \& Love, 2001). 139

Table A.2: Case study for quantities analysis (Suzuki \& Oka, 1998). 139

Table A.3: Energy intensity of construction (MJ / 1000 yen) and $\mathrm{CO}_{2}$ intensity of construction ( $\mathrm{kg} / 1000$ yen) (Suzuki \& Oka, 1998). 139

Table A.4: Summary of total initial embodied energy (Cole \& Kernana, 1996). 140

Table A.5: Case study building embodied energy results (GJ), by elements (Treloar, Fay, llozor, \& Love, 2001). 140

Table A.6: Summary of recurring embodied energy (wood structure) (Cole \& Kernana, 1996). 141

Table B.1: Shows the office areas envelope walls configuration including thickness and R/values of the concrete, steel, timber and timber-plus buildings. 143

Table B.2: Shows the schedule of buildings materials life spans organized by three sources. 143

Table B.3: Concrete building schedule of building materials suggested by the Quantitative Surveyor and then the specific alternative assigned from Alcorn (2003). 144

Table B.4: Comparison of the Alcorn and the GaBi data on embodied energy and embodied $\mathrm{CO}_{2}$ emissions of 27 buildings materials. 145

Table C.1: Operational energy segregated in consumption components. 146

Table C.2: Operating $\mathrm{CO}_{2}$ emissions segregated into end-uses 151

Table D.1: Life-cycle energy consumption and $\mathrm{CO}_{2}$ emissions using Alcorn coefficients 152

Table D.2: Life-cycle energy consumption and $\mathrm{CO}_{2}$ emissions using $\mathrm{GaBi}$ coefficients 153 


\section{List of Figures:}

Figure 3-1: Perspective view of the laboratory building of the School of Biological Science. 32

Figure 3-2: Level 4 - floor plan of the School of Biological Science building and Zoology building with atrium in between, connecting both buildings. 33

Figure 3-3: Plan of the simplified layout used in the concrete, steel, timber and timber-plus buildings. 34

Figure 3-4: North-east façades perspective view of the alternative concrete building North façade. 36

Figure 3-5: South-west façades perspective view of the alternative concrete building. 37

Figure 3-6: Structural floor plan of the laboratory building including the atrium structure (not included in the concrete building alternative version). 38

Figure 3-7: Steel building, North-east and South-west perspective views. 39

Figure 3-8: Sketches of the layout of the steel building structure compared with the layout of the concrete structure. 40

Figure 3-9: Structural slice through one floor of the timber and timber-plus building. 41

Figure 3-10: Timber building, North-east and South-west perspective views. 42

Figure 3-11: Timber-plus building, North-east and South-west perspective views. 43

Figure 3-12: 'Common finishes' of the concrete, steel and timber buildings, compared with the internal finishes of the timber-plus building. 44

Figure 3-13: Definitive plan used and cross section trough ventilation chimneys 45

Figure 4-1: Annual operational energy segregated into end-uses for the concrete, steel, timber and timberplus buildings. 66

Figure 4-2: Annual energy consumption for heating and cooling for the concrete, steel, timber and timber-plus building. 69

Figure 4-3: Initial and recurrent embodied energy for the concrete, steel, timber and timber-plus buildings are presented in two parallel graphs, showing the results produced using the GaBi and the Alcorn database. _ 74 Figure 4-4: Total embodied energy segregated into five major building components (foundations, structure, envelope, interior finishes and windows and louvers) for the concrete, steel, timber and timber-plus buildings (using the GaBi database). 78

Figure 4-5: Total embodied energy segregated into five major building components for the concrete, steel, timber and timber-plus buildings (using the Alcorn database). 79

Figure 4-6: Total life-cycle energy consumption; results produced using the GaBi database. 81

Figure 4-7: Total life-cycle energy consumption using the Alcorn database. 82

Figure 4-8: Annual operating $\mathrm{CO}_{2}$ emissions divided into end-uses for the concrete, steel, timber and timberplus buildings. 86

Figure 4-9: Initial and recurrent embodied $\mathrm{CO}_{2}$ emissions produced in separated graphs using the $\mathrm{GaBi}$ and Alcorn databases. 90

Figure 4-10: Total embodied $\mathrm{CO}_{2}$ segregated into five major building components (foundations, structure, envelope, interior finishes, and windows and louvers) for the four buildings (using the GaBi database).

Figure 4-11: Total embodied $\mathrm{CO}_{2}$ segregated into five major building components for the concrete, steel, timber and timber-plus buildings (using the Alcorn database). 93

Figure 4-12: Life-cycle $\mathrm{CO}_{2}$ emissions using the $\mathrm{GaBi}$ database for the calculation of initial and recurrent embodied $\mathrm{CO}_{2}$ emissions. 97 
Figure 4-13: Life-cycle $\mathrm{CO}_{2}$ emissions using the Alcorn database to calculate the initial and recurrent embodied $\mathrm{CO}_{2}$ emissions. 98

Figure 5-1: Annual operational energy segregated into end-uses for the four buildings. 103

Figure 5-2: Percentages of energy consumption and $\mathrm{CO}_{2}$ emissions in end-uses. 104

Figure 5-3: Total embodied energy segregated into five major building components for the concrete, steel, timber and timber-plus buildings (using the Alcorn database) 110

Figure 5-4: Total embodied $\mathrm{CO}_{2}$ segregated into five major building components for the concrete, steel, timber and timber-plus buildings (using Alcorn coefficients) 111

Figure 5-5: Concrete, steel and timber buildings using timber components total embodied energy (Alcorn coefficients) 113

Figure 5-6: The total embodied energy of the initial cases compared against the total embodied energy of the cases with component replacement. 114

Figure 5-7: Total embodied $\mathrm{CO}_{2}$ of the concrete, steel and timber buildings that are using timber components (Alcorn coefficients). 115

Figure 5-8: The total embodied $\mathrm{CO}_{2}$ emissions of the initial cases compared against the total embodied $\mathrm{CO}_{2}$ emissions of the cases with component replacement. 116

Figure 5-9: Summary of the life-cycle energy consumption of the four buildings using Alcorn and GaBi coefficients for the initial and recurrent embodied energy calculation. 118

Figure 5-10: Summary of the life-cycle $\mathrm{CO}_{2}$ emissions of the four buildings using Alcorn and $\mathrm{GaBi}$ coefficients for initial and recurrent embodied $\mathrm{CO}_{2}$ calculation. 119

Figure C.1: Summer average week operative temperature of the concrete, steel and timber building (averaged) compared with outside Dry-Bulb temperature. 147

Figure C.2: Summer average week operative temperature in the concrete and timber building. 148

Figure C.3: Winter average week inside operative temperature of the concrete building compared with outside temperature. 149

Figure C.4: Winter average week operative temperature in the concrete and timber buildings. 150 


\section{Abstract}

This thesis studies the influence of construction materials on the life-cycle energy consumption and carbon dioxide $\left(\mathrm{CO}_{2}\right)$ emissions of medium sized low energy consumption commercial buildings.

When describing buildings by materials, there is a tendency to label them according to the main structural material used. However, the vast majority of commercial buildings use a large number of materials. Hence it is not clear which materials or combinations of materials can achieve the best performance, in terms of lifecycle energy use and $\mathrm{CO}_{2}$ emissions.

The buildings analysed here were based on an actual six-storey $4250 \mathrm{~m}^{2}$ (gross floor area) building, with a mixed-mode ventilation system, currently under construction at the University of Canterbury in Christchurch. While the actual building is being constructed in concrete, the author has designed two further versions in which the structures and finishes are predominantly steel or timber. Despite having different structural materials, large quantities of finishes materials are common to all three buildings; large glazed curtain walls and sun louvers, stairs balustrade and most of the offices internal finishes.

A fourth building was also produced in which all possible 'common finishes' of the timber building were replaced by timber components. This building is labelled as Timber-plus and was included to assess the difference of the three initial 'common finishes' buildings against a building that might be expected to have a low or even negative total embodied $\mathrm{CO}_{2}$ emission in structure and finishes.

In order to highlight the influence of materials, each building was designed to have a similar indoor climate with roughly the same amount of operational energy for heating and cooling over its full life.

Both energy use and $\mathrm{CO}_{2}$ emissions have been assessed over three main stages in the life (and potential environmental impact) of a building: initial production of the building materials (initial embodied energy and initial embodied $\mathrm{CO}_{2}$ emissions); operation of the building (mainly in terms of its energy use); and the refurbishment and maintenance of the building materials over the building's effective life (recurrent embodied energy and $\mathrm{CO}_{2}$ emissions).

Calculation of embodied energy and embodied $\mathrm{CO}_{2}$ emissions are based on materials' estimates undertaken by a Quantity Surveyor. DesignBuilder software was used to estimate whole life-cycle energy used and $\mathrm{CO}_{2}$ emitted in the operation of the buildings over a period of 60 years.

Two different methods for embodied energy and embodied $\mathrm{CO}_{2}$ calculation were applied to the four buildings. The first method was by multiplying the volume of each material in the schedule calculated by the Quantity Surveyor by the New Zealand specific coefficients of embodied energy and embodied $\mathrm{CO}_{2}$ produced by Andrew Alcorn (2003). The second method was analysing the same schedule of materials with GaBi professional LCA software. Materials' inventories in GaBi are average German industry data collected by PE Europe between 1996 and 2004 (Alcorn, 2003; Nebel \& Love, 2008). 
Abstract

The energy results of the thesis show that when using the Alcorn coefficients, the total embodied energy (initial plus recurrent embodied energy) averaged $23 \%$ and operating energy consumption averaged $77 \%$ of the total life-cycle energy consumption for the four buildings. Using the GaBi coefficients, total embodied energy averaged $19 \%$ and operating energy consumption averaged $81 \%$ of the total life-cycle energy consumption of the four buildings.

Using the Alcorn coefficients, the difference between the highest (steel building) and lowest (timber-plus building) life-cycle energy consumption represents a $22 \%$ increment of the highest over the lowest. Using the $\mathrm{GaBi}$ coefficients, the difference between the lowest (timber-plus building) and the highest (timber building) life-cycle energy consumption represents a 15\% increment of the highest over the lowest.

The $\mathrm{CO}_{2}$ results shows that when using the Alcorn coefficients, the total embodied $\mathrm{CO}_{2}$ emissions averaged $7 \%$ and operating $\mathrm{CO}_{2}$ emissions averaged $93 \%$. Using the $\mathrm{GaBi}$ coefficients, total embodied $\mathrm{CO}_{2}$ emissions averaged $16 \%$ and operating $\mathrm{CO}_{2}$ emissions averaged $84 \%$ of the life-cycle $\mathrm{CO}_{2}$ emissions of the four buildings.

Using the Alcorn coefficients, the difference between the highest (steel building) and lowest (timber-plus building) life-cycle $\mathrm{CO}_{2}$ emissions represents a $27 \%$ increment of the highest over the lower. Using the $\mathrm{GaBi}$ coefficients, the difference between the highest (timber building) and the lowest (timber-plus building) lifecycle $\mathrm{CO}_{2}$ emissions represents a $9 \%$ increment of the highest over the lowest.

While for the case of embodied energy the Alcorn results averaged $32 \%$ higher than the $\mathrm{GaBi}$, in the case of embodied $\mathrm{CO}_{2}$ the Alcorn results averaged $62 \%$ lower than the $\mathrm{GaBi}$. Major differences in the results produced when using the two different sets of embodied energy and $\mathrm{CO}_{2}$ coefficients are due mainly to their different approaches to the $\mathrm{CO}_{2}$ sequestration in timber materials. While the Alcorn coefficients account for the $\mathrm{CO}_{2}$ sequestration of timber materials, the $\mathrm{GaBi}$ coefficients do not. This is particularly noteworthy as the $\mathrm{CO}_{2}$ sequestration of timber has been neglected in previous research.

It was established that embodied energy can significantly influence the life-cycle energy consumption and $\mathrm{CO}_{2}$ emissions of contemporary low energy buildings. Using the Alcorn coefficients, the steel building embodied the equivalent of 27 years of operating energy consumption and 12 years of operating $\mathrm{CO}_{2}$ emissions. At the other end of the spectrum the timber-plus building embodied the equivalent of 11 years of operating energy consumption and has stored the equivalent of 3.6 years of operating $\mathrm{CO}_{2}$ emissions.

Using the $\mathrm{GaBi}$ coefficients, the steel building embodied the equivalent of 19 years of operating energy consumption and 14 years of operating $\mathrm{CO}_{2}$ emissions, while the timber-plus building embodied the equivalent of 8 years of operating energy consumption and 8 years of operating $\mathrm{CO}_{2}$ emissions.

These findings are of significance, for example, in the assessment and weighting of the embodied energy and embodied $\mathrm{CO}_{2}$ components of building sustainable rating tools. 
Abstract 
Introduction

\section{INTRODUCTION:}

The introductory chapter discusses the specific context in which this research project was undertaken and latent implications of the results found, leading on to the problem statement, including the objectives.

\subsection{Buildings' environmental implications}

The growing concentration of atmospheric carbon dioxide $\left(\mathrm{CO}_{2}\right)$ contributing to global climatic change, is a long-term and large-scale problem (Bernstein, Peter, Canziani, \& Huq, 2007; Houghton et al., 1998). Strategies to reduce this issue include reducing fossil fuel emissions and increasing carbon sinks (Borjesson \& Gustavsson 2000; Buchanan \& Honey, 1994; Gustavsson, Pingoud, \& Sathre, 2006).

Buildings have a significant impact on the environment, consuming $32 \%$ of the world's resources, including $12 \%$ of its water and up to $40 \%$ of its energy. Buildings are also responsible for $40 \%$ of the waste which ends up in the landfills and $40 \%$ of the greenhouse gas emissions (NZ Green Building Council, 2007; World Green Building Council, 2006).

All these impacts can be directly associated with each of the building's life stages that occur during its effective life - its construction, operation, maintenance, renovation, and so on.

Architects are being forced to radically re-appraise the nature of their role. Having traditionally thought of themselves as enhancing the environment, they must now consider seriously the potential environmental impacts of their activities and those of the building industry generally. There is an urgent need for information that will enable architects and the building industry in general to assess these environmental impacts. There is also a need for tools that will allow them to make an unbiased assessment of any negative effects of their activities on the wider environment and thus fulfil their professional responsibilities to both their clients and to the wider community.

This research will attempt to provide some of that information by exploring the influence of concrete, steel or wood as the main construction material for the sub-structure, super-structure and finishes of a six-storey commercial building, over a nominal 60 year life-cycle.

Considerable effort has already gone into addressing these issues for domestic scale buildings (Alcorn, 2008; Baird \& Chan, 1983; Lippke, Wilson, Perez-Garcia, Bowyer, \& Meil, 2004; Mithraratne \& Vale, 2004), which because of their greater numbers tend to be perceived as having the largest impact on a national scale. In addition, residential construction tends to be simpler than commercial construction, hence it is more readily classified and standardised, making analysis of energy and materials' impacts relatively straightforward.

Commercial-scale buildings, on the other hand, tend to be 'one-off' buildings with a wide range of functions, making them much more difficult to classify and analyse; and while their total numbers may be less than 
Introduction

residential buildings, they consume a significant proportion of most western nations' energy and materials resources.

\subsubsection{New Zealand}

The New Zealand Ministry of Economic Development reported in 2005 that commercial (11\%) and residential buildings (13\%) consumed 24\% (111 PJ) of the total National energy supply (New Zealand Energy Efficiency and Conservation Authority and the Ministry for the Environment, 2006).

The New Zealand Ministry for the Environment has also estimated that in total, over eight million tonnes of $\mathrm{CO}_{2}$ was emitted into the atmosphere in 2005 (New Zealand Energy Efficiency and Conservation Authority and the Ministry for the Environment, 2006). In addition, three million tonnes of construction and demolition debris was sent to landfills by New Zealand industries and households (Thornton \& New Zealand Ministry for the Environment, 2001).

The total $\mathrm{CO}_{2}$ emissions associated with the construction of buildings in New Zealand is over two million tonnes each year. This number is relatively lower than in many other countries because New Zealand generates about three quarters of its electricity from renewable hydro power. This directly reduces the amount of fossil fuel being burned (Buchanan, 2006).

\subsection{Buildings' materials}

In terms of energy consumption, much of the existing commercial building stock is made up of multi-storey, highly-glazed, thermally-lightweight developments that are totally dependent on non-renewable energy for heating, cooling and lighting.

In terms of materials, most commercial buildings tend to make extensive use of steel, glass and concrete, all of which can be energy-intensive to produce, via processes with the potential to have adverse environmental impacts and using resources that are in shortening supply. More recently, developments in wood technology have enabled timber to be utilised more extensively for the basic structure of medium-rise buildings and this is investigated in this thesis.

In this regard, it is worth noting the commercial rivalries that can exist between the purveyors of competing materials, each promoting the potential environmental advantages of their respective products - the thermal mass properties of concrete, the recycle-ability of steel, the renew-ability of wood, and so on - and the necessity for an independent academic researcher to remain detached from these influences.

While there is a tendency for commercial buildings to be labelled according to the main material used for their sub- and super-structures, the vast majority of buildings use a large number of materials. Hence it is often not clear which materials or combinations of materials can achieve the best environmental performance (in terms of life-cycle energy use and $\mathrm{CO}_{2}$ emissions, for example). Nevertheless this thesis will retain this labelling system (while conscious of its limitations), as it is current practice. 
Introduction

Studies have indicated that on average the structural components account for between 16 and 65\% of initial embodied energy (Aye, Bamford, Charters, \& Robinson, 1999; Cole \& Kernan, 1996; Oppenheim \& Treloar, 1995; Treloar, Fay, llozor, \& Love, 2001).

\subsubsection{Life-cycle assessment}

Buildings go through many stages throughout their useful life, none of which are particularly simple to analyse from an environmental point of view. From the initial conception to final recycling, re-use or demolition of a building, a whole range of processes must be taken into account. These include transportation to site, site erection and construction, lifetime use of the building, repairs, maintenance and refurbishment, demolition or dismantling it at the end of its life, transportation for reuse, and recycling or disposal (Cole \& Kernan, 1996; Eaton \& Amato, 1998). In short, a full Life Cycle Analysis (LCA) is required if one is to properly and thoroughly assess the environmental impact of a building.

As far as the selection of appropriate indicators of environmental impact is concerned, energy has long been the measurement of choice (Alcorn, 1998; Baird \& Chan, 1983; Baird \& Newsam, 1986; Stein, Stein, Buckley, \& Green, 1980). Operational energy use is relatively straightforward to assess. With international protocols (IFIAS, 1974) in place for the assessment of the embodied energy of materials (which tend to be country-specific), embodied energy calculations have been the subject of considerable study, particularly following the various 'energy crises' in the latter part of the twentieth century.

More recently, it has been suggested that $\mathrm{CO}_{2}$ emissions may be a more meaningful single indicator of overall global environmental impact. In many cases it is feasible to calculate $\mathrm{CO}_{2}$ emissions from energy data, though again this tends to be country-specific, depending on the energy mix and industrial base of the region and chemical releases of $\mathrm{CO}_{2}$.

In this study, both energy use and $\mathrm{CO}_{2}$ emissions have been assessed using the following six main stages in the life (and potential environmental impact) of a building:

- Initial production of the building materials

- Construction of the building

- Operation of the building (mainly in terms of its energy use)

- Refurbishment and maintenance of the building materials over the building's effective life

- Demolition of the building

- Disposal of the building materials at end of life

The focus of this research will be on the initial production of the building materials, operation of the building and refurbishment, and maintenance of the building materials over the building's effective life. 
Introduction

\subsection{Problem statement}

The aim is to determine the influence of construction materials on the life-cycle energy use and $\mathrm{CO}_{2}$ emissions of medium sized commercial buildings. A secondary aim is to identify if the use of different sets of embodied energy and $\mathrm{CO}_{2}$ coefficients does influence the outcome and how.

\subsection{Scope}

An LCA is an analytical methodology that assesses the environmental performance of a building by taking a system perspective over the whole life-cycle, from cradle to grave (Nebel, 2007; Zsuzsa \& Nebel, 2006). Normally an LCA involves various environmental assessments such as emissions, wastes and resources used from all of the buildings life stages from initial conception to final recycling or disposal. In this study, the scope of the assessment is reduced to energy use and $\mathrm{CO}_{2}$ emissions, in the following three main stages in the life (and potential environmental impact) of a building:

- Initial production of the building materials

- Operation of the building

- Maintenance of the building materials over the building's effective life

Other stages such as the construction of the building, and its demolition and disposal are not included because these are much more difficult to assess, and in the case of demolition and disposal previous studies agree that these contributes a relatively small amount to their respective totals life cycle energy consumption and life-cycle $\mathrm{CO}_{2}$ emissions (Cole \& Kernan, 1996; Suzuki \& Oka, 1998). 
Introduction

\subsection{Research questions:}

This thesis will answer the following questions:

1. Can concrete, steel, timber and timber-plus buildings be designed to have (similar) low operating energy consumption?

2. What is the influence of construction materials on operating $\mathrm{CO}_{2}$ emissions?

3. What is the influence of construction materials on the embodied energy in a building?

4. What is the influence of construction materials on embodied $\mathrm{CO}_{2}$ emissions?

5. What is the influence of construction materials on the relative proportion of embodied energy to total life-cycle energy consumption?

6. What is the influence of construction materials on the relative proportion of embodied $\mathrm{CO}_{2}$ emissions to total life-cycle $\mathrm{CO}_{2}$ emissions?

7. How does the choice of finishing materials affect the life-cycle energy use and $\mathrm{CO}_{2}$ emissions?

8. How does the use of different sets of embodied energy and embodied $\mathrm{CO}_{2}$ coefficients influence the answer to all previous questions? 
Introduction

\subsection{Key definitions:}

1. Life-cycle assessment (LCA): Is a methodology used to assess the environmental performance of a building by accounting for the whole life-cycle on a wide range of environmental issues - not just concentrating on issues such as embodied energy and embodied $\mathrm{CO}_{2}$ emissions, but also issues such as climate change, fossil fuel depletion, water pollution, mineral extraction and waste disposal are recognised and analysed.

2. Life-Cycle Inventory ( $\mathrm{LCl})$ : The use of a $\mathrm{LCl}$ is fundamental to undertake a LCA. It is the database of all relevant building material's inputs and outputs of energy and mass flow, as well as data on emissions to air, water and land.

3. Embodied energy: Is the energy consumed during the process of manufacturing materials. The boundaries of the process are from the raw material extraction until the final stage of the manufacturing process (from cradle to gate). Sometimes in this thesis embodied energy is labelled as initial embodied energy.

4. Embodied $\mathrm{CO}_{2}$ emissions: In this thesis, embodied $\mathrm{CO}_{2}$ emissions encompass all the $\mathrm{CO}_{2}$ emitted during the process of the materials' manufacture. $\mathrm{CO}_{2}$ might be released from the generation of electricity in which the production mix involves fossil fuels, and also from the use of carbonaceous materials utilised in cement production. Sometimes in this thesis embodied $\mathrm{CO}_{2}$ emissions are labelled as initial embodied $\mathrm{CO}_{2}$ emissions.

5. Recurrent embodied energy and recurrent embodied $\mathrm{CO}_{2}$ emissions: These are the embodied energy and embodied $\mathrm{CO}_{2}$ emissions of the materials added to the buildings by replacement, due to maintenance undertaken during the 60 years of effective life. In this thesis recurrent embodied energy and recurrent embodied $\mathrm{CO}_{2}$ emissions do not account for refurbishment, only maintenance.

6. Total embodied energy: In this thesis it is the sum of the initial embodied energy and recurrent embodied energy.

7. Total embodied $\mathrm{CO}_{2}$ emissions: In this thesis it is the sum of the initial embodied $\mathrm{CO}_{2}$ emissions and recurrent embodied $\mathrm{CO}_{2}$ emissions.

8. Operating energy consumption: Is the energy consumed by the HVAC to heat, cool and light the interior spaces and to power equipment and other services in the building. It varies considerably with building use patterns, climate and season and the efficiency of the buildings and its systems. In New Zealand, the energy use is normally electricity for cooling, lighting and equipment, and gas is normally used for heating and domestic hot water.

9. Operating $\mathrm{CO}_{2}$ emissions: Is the conversion of the operating energy into $\mathrm{CO}_{2}$ emissions by the use of New Zealand-specific $\mathrm{CO}_{2}$ factors for energy sources such as electricity, gas, LPG, etc. 
Introduction

10. Life-cycle energy consumption: Is the building's energy consumption incurred during the construction, use and removal of the building. Life-cycle energy consumption in this thesis is calculated by adding the operating energy consumption and total embodied energy. Total embodied energy was calculated by adding the initial embodied energy and the recurrent embodied energy.

11. Life-cycle $\mathrm{CO}_{2}$ emissions: Is the building's $\mathrm{CO}_{2}$ emissions incurred during the production, use and removal of the building. Life-cycle $\mathrm{CO}_{2}$ emissions in this thesis are calculated adding the same life stages as in life-cycle energy consumption.

12. Demolition energy: Demolition energy is the energy use to demolish buildings, the subsequent transport and the disposing of the building's waste materials at the end of its effective life.

13. Sequestered $\mathrm{CO}_{2}$ : Growing trees removes carbon from the atmosphere and this is expressed as $\mathrm{CO}_{2}$ emissions which have not occurred because the carbon is 'locked up' in the tree and subsequently in timber materials. Negative embodied $\mathrm{CO}_{2}$ emissions in timber materials mean that the emissions corresponding to the raw material extraction and the manufacturing do not exceed the amount of $\mathrm{CO}_{2}$ removed from the atmosphere.

14. $\mathrm{CO}_{2}$ equivalent: In some $\mathrm{LCl}$ databases $\mathrm{CO}_{2}$ data considers all greenhouse gases including methane, CFCs and HCFCs, with the results converted into tonnes of $\mathrm{CO}_{2}$ equivalent emissions.

15. Cradle to gate: Means that the assessment of the material included in the $\mathrm{LCl}$ database includes all phases from raw material extraction to the end of the manufacturing process (until the manufacturing site gates). No transportation from the manufacturing site to the construction site and no end of life assumptions are added to the materials assessment. 
Introduction

\subsection{Research overview}

This thesis is divided into six main chapters, with the current introduction section providing the specific context in which this research project was undertaken, leading up to the problem statement and the objectives.

Chapter 2 reviews and discusses literature regarding the different life stages of building's life-cycle energy consumption and $\mathrm{CO}_{2}$ emissions. It presents the order of magnitudes between the energy consumption and $\mathrm{CO}_{2}$ emissions life stages that an office building incurred during its effective life-cycle.

Chapter 3 describes the methodology employed in this research to determine the life-cycle energy use and $\mathrm{CO}_{2}$ emissions of the case study buildings. To achieve this, the first part of this chapter describes the case study design with emphasis on the great care taken to ensure a realistic design of the four buildings used as case studies in the assessment. Chapter 3 will also provide the rationale and describe all the different variables involved in the calculation of all life stages analysed in this thesis. Emphasis will be placed on operating energy and $\mathrm{CO}_{2}$ emissions, initial embodied energy and $\mathrm{CO}_{2}$ emissions, and recurrent embodied energy and $\mathrm{CO}_{2}$ emissions.

Chapter 4 acquaints the reader with the results produced from the assessment of operating energy consumption and operating $\mathrm{CO}_{2}$ emissions, initial embodied energy and initial embodied $\mathrm{CO}_{2}$ emissions, and finally recurrent embodied energy and recurrent $\mathrm{CO}_{2}$ emissions. It presents the results regarding life-cycle energy consumption and life-cycle $\mathrm{CO}_{2}$ emissions separately.

Chapter 5 discusses the results found in this study and compares the different performances of each of the four case studies produced in this research against other published data.

Conclusions related to each of the research questions are presented in Chapter 6 . The chapter concludes by suggesting future implications and research avenues.

The Appendices found in the rear of this document provide additional information to support the rationale, assumptions and findings of this research project. Finally, the architectural drawings of the four case studies, the schedules of materials and the spread sheet with the calculations of embodied energy and embodied $\mathrm{CO}_{2}$ emissions are on an attached $\mathrm{CD}$. 
Introduction 


\section{Literature review:}

This chapter introduces the different components of building's life-cycle energy consumption and $\mathrm{CO}_{2}$ emissions. It will also present the order of magnitudes between each of those life-cycle components. The chapter is based on data from researches that have a main focus of study on the significance of embodied energy and embodied $\mathrm{CO}_{2}$ emissions in the total life energy consumption and $\mathrm{CO}_{2}$ emissions of an office building.

The first part of the chapter will be a review of office building's life-cycle energy consumption and $\mathrm{CO}_{2}$ emissions. Section 2.1 will summarise the life-cycle energy use and $\mathrm{CO}_{2}$ emissions components and will segregate them in order of influence. After all the life-cycle components are introduced, the following sections will present the data for the four most significant life-cycle components, being: initial embodied energy consumption and $\mathrm{CO}_{2}$ emissions, recurrent embodied energy consumption and $\mathrm{CO}_{2}$ emissions, operating energy consumption and $\mathrm{CO}_{2}$ emissions, and finally demolition energy consumption and $\mathrm{CO}_{2}$ emissions.

Section 2.2 presents the summary of operating energy consumption and $\mathrm{CO}_{2}$ emissions. A proper benchmark of office buildings' operating energy consumption is given in Chapter 4 when the results are presented. Section 2.3 will introduce the embodied energy and embodied $\mathrm{CO}_{2}$ emissions. As part of Section 2.3, embodied energy and embodied $\mathrm{CO}_{2}$ emissions are segregated into initial embodied energy and initial $\mathrm{CO}_{2}$ emissions and recurrent embodied energy and recurrent embodied $\mathrm{CO}_{2}$ emissions. Section 2.4 will show the results of buildings total embodied energy and total embodied $\mathrm{CO}_{2}$ emissions disaggregated into structure and finishes buildings components. Section 2.5 will introduce demolition energy and $\mathrm{CO}_{2}$ emissions as the last of the life cycle components in a building's life cycle.

It is also included in Sections 2.2, 2.3, 2.4, 2.5, the data from researches that have studied the same type of building's life cycle component, but in buildings built using concrete, steel and timber as the material used for the structure and in most of the finishes. This data is then finally summarised in Section 2.7.

Finally Section 2.6 presents different researches on where the life-cycle energy consumption and life-cycle $\mathrm{CO}_{2}$ emissions are studied in 'low energy' consumption buildings. 


\subsection{Office buildings' life-cycle energy consumption and $\mathrm{CO}_{2}$ emissions components}

This thesis' main focus is on the building's energy consumption and $\mathrm{CO}_{2}$ emissions incurred during the production, use and removal of a commercial building. Cole and Kernan (1996) suggest distinguishing between the following four distinct categories of a building's life-cycle energy consumption.

- The energy to initially produce the building (Initial embodied energy).

- The recurring embodied energy required to refurbish and maintain the building over its effective life.

- The operational energy, which is the energy use in the operation of the building, for example the energy use to condition the building (heating, cooling and ventilation), light the interior space and to power the equipment and other services.

- Energy to demolish and dispose of the building at the end of its effective life.

Eaton and Amato (1998) suggest a slightly more detailed sequence of life stages:

- Transportation to site.

- Site erection and construction.

- Life-time of the building or structure.

- Repairs.

- Maintenance and refurbishment.

- Demolition or dismantling of the structure at the end of its life.

- Transportation for reuse.

- Recycling or disposal.

From all of the building's life stages, energy and $\mathrm{CO}_{2}$ emissions of construction and demolition phases are normally neglected and not accounted into the life-cycle energy use and $\mathrm{CO}_{2}$ emissions of buildings (Aye et al., 1999; Cole \& Kernan, 1996; Oppenheim \& Treloar, 1995; Page, 2006; Treloar et al., 2001).

By the other hand from all different environmental burdens, the researches commonly found are carried out for just a selection of environmental impacts. These are typically energy use and in some cases $\mathrm{CO}_{2}$ emissions (Eaton \& Amato, 1998, pp. 1-2; Gustavsson, Pingoud, \& Sathre, 2006; Lippke et al., 2004; Page, 2006).

The following sections will present the data found, mainly regarding initial and recurrent embodied energy and initial and recurrent $\mathrm{CO}_{2}$ emissions, operating energy and operating $\mathrm{CO}_{2}$ emissions, and finally demolition energy and demolition $\mathrm{CO}_{2}$ emissions. 


\subsection{Operating energy consumption and $\mathrm{CO}_{2}$ emissions}

Operational energy of buildings is the energy required to condition (heat, cool and ventilate) and light the interior spaces and to power equipment and other services. It varies considerably with building use patterns, climate and season, and the efficiency of the buildings and its systems (Cole \& Kernan, 1996)

Energy use in operations is by far the largest component of the life-cycle energy use. It is far larger than the construction energy, initial embodied energy, recurrent embodied energy and demolition energy all added together (Aye et al., 1999; Cole \& Kernan, 1996; Oppenheim \& Treloar, 1995; Page, 2006; Suzuki \& Oka, 1998).

Cole and Kernan (1996) conclude that for a building designed following conventional energy performance standards operational energy will be the largest component of the life-cycle energy consumption. The study states that only as the energy efficiency of the buildings improve, the amount of energy required to produce them - embodied energy - will represent an increasing component of the life-cycle energy consumption (Cole \& Kernan, 1996).

Page (2006) briefly ranked the energy use components of life-cycle energy use of the buildings studied in that research. He said that in terms of energy consumption, the operation of office buildings is ranked first and contributes to $82 \%$ of the life-cycle energy consumption, while construction work contributes only $15 \%$. For the single storey health building studied in his study over a 50 year life period, if construction contributes $15 \%$ of the energy consumption, embodied energy accounts for between $7 \%$ and $9 \%$ of the life-cycle energy use (Page, 2006).

Table 2.1 shows the summary of operational energy and $\mathrm{CO}_{2}$ emissions of the buildings analysed by the papers in this literature review. It can be seen that for office buildings, their operating energy range is from 266 to $454 \mathrm{kWh} / \mathrm{m}^{2}$ per year.

It is important to mention that there could be a different ranking of life-cycle energy components found in more energy efficient buildings. In (Oppenheim \& Treloar, 1995), in a two storey low energy building: the initial embodied energy was calculated to be $5.5 \mathrm{GJ} / \mathrm{m}^{2}$ of gross floor area (GFA) and it was estimated to be equal to between 21 to 37 years of operational energy (Oppenheim \& Treloar, 1995).

Suzuki and Oka (1998) studied the energy consumption and $\mathrm{CO}_{2}$ emission operations of ten office buildings in Japan, and the data of the annual electric power rate of each (A-J) building from 1987 to 1993 was obtained by a survey of monthly power bills of electric rates for each building. The average annual energy consumption was determined to be $1.21 \mathrm{GJ} / \mathrm{m}^{2}\left(336 \mathrm{kWhlm}{ }^{2}\right)$ and the average annual $\mathrm{CO}_{2}$ emission was 87 $\mathrm{Kg} / \mathrm{m}^{2}$.

Further in Chapter 4 of this thesis, a summary of New Zealand office buildings' operating energy consumption will be given in order to have a benchmark to compare the results found. Data given in this section is obtained from researches that look at the energy consumption and in some cases the $\mathrm{CO}_{2}$ 
emissions of various office buildings' life stages. Data presented in this section can not be used as a benchmark for operating energy consumption of office buildings, to look into this in more detail, the reader will need to read Chapter 4, Section 4.1.1.1, 'Operating energy consumption benchmarks'.

\begin{tabular}{|c|c|c|c|c|c|c|c|}
\hline \multirow[t]{3}{*}{ Case } & \multicolumn{4}{|c|}{ Building Characteristics } & \multicolumn{2}{|c|}{ energy consumption } & \multirow{3}{*}{ Ref } \\
\hline & Size $\left(m^{2}\right)$ & Storeys & Structure & Location & Total & & \\
\hline & & & & & $\overline{\mathrm{kWh} / \mathrm{m}^{2} \cdot \mathrm{yr}}$ & & \\
\hline Out-patient & 1,641 & 1 & Concrete & New Zealand & 187.40 & 2006 & (G) \\
\hline Out-patient & 1,641 & 1 & Timber & New Zealand & 194.13 & 2006 & (G) \\
\hline Out-patient & 1,641 & 1 & Steel & New Zealand & 187.59 & 2006 & (G) \\
\hline Gym & 680 & 1 & Concrete & New Zealand & 44.73 & 2006 & (G) \\
\hline Gym & 680 & 1 & Timber & New Zealand & 45.27 & 2006 & (G) \\
\hline Gym & 680 & 1 & Steel & New Zealand & 45.27 & 2006 & (G) \\
\hline 10 cases & (Average) & & & & & & \\
\hline Offices & 4,321 & 7 Aver & _- & Japan & 336 & 1997 & (E) \\
\hline & & & & In Canada & & & \\
\hline Office & 4,620 & 3 & Timber & Vancouver & 266.41 & 1995 & (C) \\
\hline Office & 4,620 & 3 & Steel & Vancouver & 266.41 & 1995 & (C) \\
\hline Office & 4,620 & 3 & Concrete & Vancouver & 266.41 & 1995 & (C) \\
\hline Office & 4,620 & 3 & Timber & Toronto & 454.48 & 1995 & (C) \\
\hline Office & 4,620 & 3 & Steel & Toronto & 454.48 & 1995 & (C) \\
\hline Office & 4,620 & 3 & Concrete & Toronto & 454.48 & 1995 & (C) \\
\hline
\end{tabular}

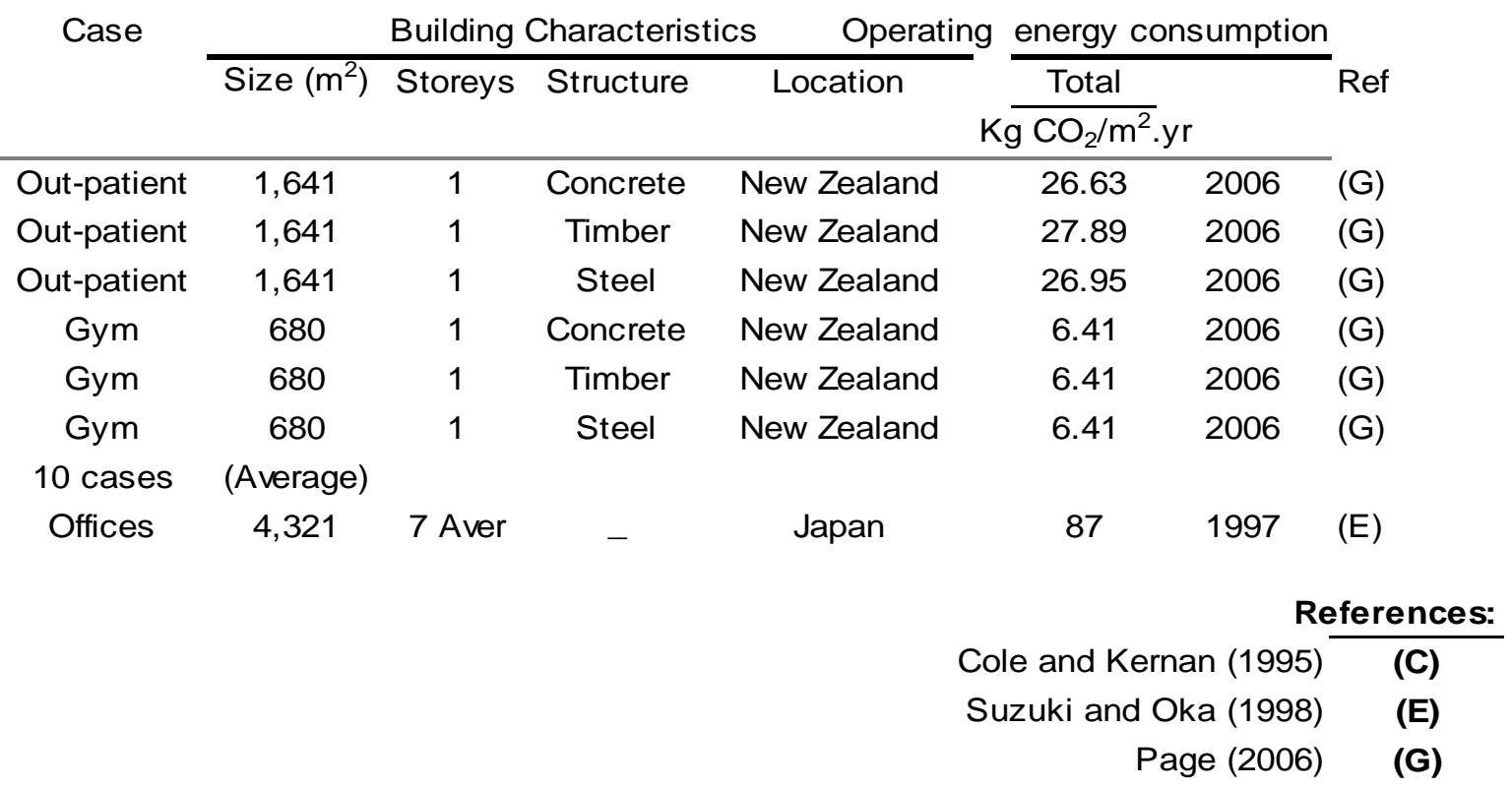

Table 2.1: Summary of operational energy and $\mathrm{CO}_{2}$ emissions of the buildings analysed by the papers in this literature review 


\subsection{Embodied energy and embodied $\mathrm{CO}_{2}$ emissions}

Embodied energy is the energy consumed in all activities necessary to support a process, and comprises of both direct and indirect components (Baird \& Chan, 1983).

In building construction, direct energy includes building assembly and indirect energy includes the energy embodied in building materials and products (Treloar et al., 2001). As it was said in Cole and Kernan (1996), "normally embodied energy typically describes only the energy to initially produce a building and does not include the energy associated with maintaining, repairing and replacing material and components over the life of a building, hence the importance of using the designation initial".

In addition to the embodied energy, some processes in the production of building materials release $\mathrm{CO}_{2}$, mainly due to the use of fossil fuel in the electricity mix used as energy in the production of the materials or for the use of carbonaceous materials. There is some research done that accounts for embodied $\mathrm{CO}_{2}$ in building materials', but this is much more infrequent than research on embodied energy (Nebel, 2007; Page, 2006). A description of the inventories of materials' environmental burdens used in this research for results production is given in Chapter 3 .

\subsubsection{Initial embodied energy and initial embodied $\mathrm{CO}_{2}$ emissions}

Initial embodied energy and initial embodied $\mathrm{CO}_{2}$ emissions are the energy and $\mathrm{CO}_{2}$ embodied in the materials used to initially build the building; it is the embodied energy and $\mathrm{CO}_{2}$ emissions of the building at the beginning of its first year of operative life. The data presented in this section does not account for the energy directly consumed and the $\mathrm{CO}_{2}$ directly emitted during the construction process of the buildings.

Table 2.2 presents a summary of several different published studies done on office buildings' embodied energy. The data is presented comparing the building characteristics against the initial embodied energy. For each building type, the embodied energy is presented differentiating the buildings characteristic and the initial embodied energy. Based on this table it can be said that typically the initial embodied energy of office buildings ranges from 3.4 to $18.4 \mathrm{GJ} / \mathrm{m}^{2}$ and the average initial embodied energy in this table is $7.9 \mathrm{GJ} / \mathrm{m}^{2}$.

Aye et al (1999) investigate the effect of the building aspect ratio (proportion between the frontage and the depth of a building) and the number of floors on the initial embodied energy of new office buildings in Melbourne, Australia. The elements of the building used in the calculations of the initial embodied energy are the floors, walls and roof. The results found that a single storey building $\left(2000 \mathrm{~m}^{2}\right)$ in Melbourne, excluding finishes, has an initial embodied energy of $2.25 \mathrm{GJ} / \mathrm{m}^{2}$. The research also found that the initial figure was reduced to between $1.5 \mathrm{GJ} / \mathrm{m}^{2}$ to $1.6 \mathrm{GJ} / \mathrm{m}^{2}$ for a three-storey building, across the range of aspect ratios investigated in this research (Aye et al., 1999). 


\begin{tabular}{|c|c|c|c|c|c|c|c|}
\hline \multirow[t]{3}{*}{ Case } & \multicolumn{4}{|c|}{ Building Characteristics } & \multicolumn{3}{|c|}{ itial embodied energy } \\
\hline & \multirow[t]{2}{*}{ Size $\left(m^{2}\right)$} & \multirow[t]{2}{*}{ Storeys } & \multirow[t]{2}{*}{ structure } & \multirow[t]{2}{*}{ Location } & Total & Year & Ref \\
\hline & & & & & \multicolumn{2}{|c|}{$\mathrm{GJ} / \mathrm{m}^{2}$} & \\
\hline office & 8,568 & 5 & Concrete & New Zealand & 6.5 & 1992 & (A) \\
\hline office & 8,568 & 5 & Steel & New Zealand & 7.8 & 1992 & (A) \\
\hline office & 2,400 & 3 & Concrete & New Zealand & 4.8 & 1992 & (A) \\
\hline office & 2,400 & 3 & Timber & New Zealand & 3.4 & 1992 & (A) \\
\hline office & Ave & $3-8$ & Timber & New Zealand & 3.7 & 1994 & (B) \\
\hline office & Ave & $3-8$ & Steel & New Zealand & 6.6 & 1994 & (B) \\
\hline office & Ave & $3-8$ & Concrete & New Zealand & 5.6 & 1994 & (B) \\
\hline office & 4,620 & 3 & Timber & Canada & 4.3 & 1995 & (C) \\
\hline office & 4,620 & 3 & Steel & Canada & 4.9 & 1995 & (C) \\
\hline office & 4,620 & 3 & Concrete & Canada & 4.5 & 1995 & (C) \\
\hline office & 69,622 & 3 & Concrete & Australia & 10.7 & 2001 & (D) \\
\hline office & 326,766 & 7 & Concrete & Australia & 11.9 & 2001 & (D) \\
\hline office & 1,879 & 8 & Concrete & Japan & 6.5 & 1997 & (E) \\
\hline office & 22,982 & 10 & Steel & Japan & 13.0 & 1997 & (E) \\
\hline office & 1,730 & 2 & Concrete & Australia & 5.5 & 1996 & (F) \\
\hline Out-patient & 1,641 & 1 & Concrete & New Zealand & 3.1 & 2006 & (G) \\
\hline Out-patient & 1,641 & 1 & Timber & New Zealand & 2.2 & 2006 & (G) \\
\hline \multirow[t]{9}{*}{ Out-patient } & 1,641 & 1 & Steel & New Zealand & 2.7 & 2006 & (G) \\
\hline & & & & \multicolumn{4}{|c|}{ References (Ref): } \\
\hline & & & & \multicolumn{3}{|c|}{ Honey and Buchanan (1992) } & $(\mathrm{A})$ \\
\hline & & & & \multicolumn{3}{|c|}{ Buchanan and Honey (1994) } & (B) \\
\hline & & & & \multicolumn{3}{|c|}{ Cole and Kernan (1995) } & (C) \\
\hline & & & & \multicolumn{3}{|c|}{ Treloar et al (2001) } & (D) \\
\hline & & & & \multicolumn{3}{|c|}{ Suzuki and Oka (1998) } & $(\mathrm{E})$ \\
\hline & & & & \multicolumn{3}{|c|}{ Oppenheim and Treloar (1996) } & (F) \\
\hline & & & & \multicolumn{3}{|c|}{ Page (2006) } & (G) \\
\hline
\end{tabular}

Table 2.2: Summary of total initial embodied energy for each of the cases in the literature review.

Treloar et al (2001) studied the relationship between embodied energy and building height for commercial buildings. Five case studies were selected on the basis of the relevant data available. Table A.1 in (Appendix A.1) present the building's data, such as number of storeys, gross floor area, total embodied energy and total embodied energy divided by the square for each of the buildings in this research. Embodied energy coefficients for building materials used in this research was determined by a hybrid analysis method, which integrated an input-output analysis and processed analysis data within the input-output framework (Treloar et al., 2001).

The results range from $10.7 \mathrm{GJ} / \mathrm{m}^{2}$ in a 3 storey building to $18.4 \mathrm{GJ} / \mathrm{m}^{2}$ in a 52 storey building. Of particular interest for this thesis, due to the analysis of 6 storey buildings, is the $11.9 \mathrm{GJ} / \mathrm{m}^{2}$ in a 7 storey building. Oppenheim and Treloar (1995) studied a low energy consumption building, the Energy Research and Development Corporation (ERDC) in Canberra. It is a two storey $1,730 \mathrm{~m}^{2}$ office building, constructed of reinforced concrete footing and slabs, steel columns and steel roof framing, and clad in brick veneer and fibre-cement sheet walls with aluminium framed double glass windows. The building contains a number of energy consumption minimising features included in the embodied energy calculation, such as special wide walls studs for insulation, wall and ceiling insulation, double glassing and a light shelf. The total initial 
embodied energy in the first 14 elements was calculated to be $9,440 \mathrm{GJ}$, or $5.5 \mathrm{GJ} / \mathrm{m}^{2}$ of GFA (gross floor area), and it was estimated to be equal to between 21 from 37 years of operational energy (Oppenheim \& Treloar, 1995).

Table 2.3 shows the summary of the results produced in the only two researches where both embodied energy and embodied $\mathrm{CO}_{2}$ were studied.

\begin{tabular}{|c|c|c|c|c|c|c|c|}
\hline Case & & \multicolumn{3}{|c|}{ Building Characteristics } & \multicolumn{3}{|c|}{ Initial embodied $\mathrm{CO}_{2}$} \\
\hline & \multirow{2}{*}{ Size $\left(m^{2}\right)$} & \multirow{2}{*}{ Storeys } & \multirow[t]{2}{*}{ structure } & \multirow{2}{*}{ Location } & Total & Year & Ref \\
\hline & & & & & $\mathrm{kg} / \mathrm{m}^{2}$ & & \\
\hline Office & 1,879 & 8 & Concrete & Japan & 650 & 1997 & (E) \\
\hline Office & 22,982 & 10 & Steel & Japan & 1,100 & 1997 & (E) \\
\hline Out-patient & 1,641 & 1 & Concrete & New Zealand & 369 & 2006 & (G) \\
\hline Out-patient & 1,641 & 1 & Timber & New Zealand & 149 & 2006 & (G) \\
\hline \multirow[t]{3}{*}{ Out-patient } & 1,641 & 1 & Steel & New Zealand & 253 & 2006 & (G) \\
\hline & & & & & \multicolumn{3}{|c|}{ References: } \\
\hline & & & & & and $\mathrm{OK}$ & (1998) & $(\mathrm{E})$ \\
\hline
\end{tabular}

Table 2.3: Summary of total initial embodied $\mathrm{CO}_{2}$ emissions from cases in the literature review.

Suzuki et al. (1998) quantify the total amount of energy consumption and $\mathrm{CO}_{2}$ emissions of office buildings in Japan. In this study, a method for estimating the life-cycle energy consumption and $\mathrm{CO}_{2}$ emissions of office buildings is proposed by using the construction price index from 1985 Input/Output (I/O) tables of Japan (Suzuki \& Oka, 1998). When looking at results produced using I/O tables Treolar et al. (2001) stated that these are representative of "national average cases but it is unreliable mainly due to assumptions regarding tariffs". Table A.2 (Appendix A.1) shows a description of floor area, number of stories and structural system used by each of the ten case studies in this research.

The study found that the energy required to construct $1 \mathrm{~m}^{2}$ of floor area varied from 6.5 to $13 \mathrm{GJ} / \mathrm{m}^{2}$ with an average value of $8.95 \mathrm{GJ} / \mathrm{m}^{2}$. A total emission of $\mathrm{CO}_{2}$ by the construction of office buildings was seen to vary from 650 to $1100 \mathrm{~kg} / \mathrm{m}^{2}$ with an average value of $790 \mathrm{~kg} / \mathrm{m}^{2}$ (Suzuki \& Oka, 1998). Table A.3 (Appendix A.1) introduces some of the values that are given as results in the $1 / O$ table and presents the level of data available for the energy and $\mathrm{CO}_{2}$ intensity of construction phases.

\subsubsection{Comparisons of concrete, timber and steel case studies}

The first six New Zealand cases referred to in Table 2.2 (Honey \& Buchanan (1992), and Buchanan \& Honey (1994)) are from a two storey $2,400 \mathrm{~m}^{2}$ timber and steel structure, and a five storey $8,568 \mathrm{~m}^{2}$ concrete and steel structure. These cases offer a comparative timber, steel and concrete structural system of embodied energy that would be applicable to typical 5-8 storey commercial buildings. By assuming the same nonstructural embodied energy per $\mathrm{m}^{2}$, the total embodied energy would be $3.70 \mathrm{GJ} / \mathrm{m}^{2}$ for the timber building, $5.60 \mathrm{GJ} / \mathrm{m}^{2}$ for the concrete building and $6.60 \mathrm{GJ} / \mathrm{m}^{2}$ for the steel building.

The three cases in Canada are part of the research undertaken by Cole and Kernan (1995) in which a $4,620 \mathrm{~m}^{2}$ three storey generic office building is redesigned utilising either timber, steel or concrete as the 
material used mainly in the structural systems (finishing materials remain the same for all cases). The results of that research show that the total initial embodied energy is $4.26 \mathrm{GJ} / \mathrm{m}^{2}, 4.86 \mathrm{GJ} / \mathrm{m}^{2}$ and $4.52 \mathrm{GJ} / \mathrm{m}^{2}$ for the timber, steel and concrete building respectively. Steel is 1.14 times greater than Concrete, and concrete is 1.06 times greater than the wood structure (Cole \& Kernan, 1996).

The out-patient building in Table 2.3 is part of a research conducted in New Zealand in 2006. A recently constructed building was selected and the structural systems were re-designed, to an extent that was 'practical and reasonable', in timber, concrete and steel. The building chosen was a health building (Outpatient) with a floor area of $1640 \mathrm{~m}^{2}$ in a single storey. The layout consists of over 35 consultation and service rooms and an educational area attached to the back of the building (Page, 2006). The results of that research show that total initial embodied energy is $3.1 \mathrm{GJ} / \mathrm{m}^{2}, 2.7 \mathrm{GJ} / \mathrm{m}^{2}$ and $2.2 \mathrm{GJ} / \mathrm{m}^{2}$ for the concrete, steel and timber building respectively (Page, 2006).

When looking at total embodied $\mathrm{CO}_{2}$ emissions, the results of that research were $369 \mathrm{Kg} / \mathrm{m}^{2}, 253 \mathrm{Kg} / \mathrm{m}^{2}$ and $149 \mathrm{Kg} / \mathrm{m}^{2}$ for the concrete, steel and timber building respectively. Note that this is a small single storey building and that not all materials and fittings have been included in the alternative designs.

\subsubsection{Summary of initial embodied energy and initial embodied $\mathrm{CO}_{2}$ emissions}

As a summary of the most relevant data in Table 2.2 and 2.3, it can be said that in Cole and Kernan (1996), the initial embodied energy of office buildings ranges from 4 to $12 \mathrm{GJ} / \mathrm{m}^{2}$. In Oppenheim and Treloar (1995), the initial embodied energy was calculated to be $5.5 \mathrm{GJ} / \mathrm{m}^{2}$ of gross floor area. Finally, in Suzuki and Oka (1998), where 10 office buildings were studied in Japan, the initial embodied energy varied from 6.5 to 13 $\mathrm{GJ} / \mathrm{m}^{2}$ with an average value of $8.95 \mathrm{GJ} / \mathrm{m}^{2}$. When looking at initial embodied $\mathrm{CO}_{2}$ emissions, the most significant figures come from Suzuki and Oka (1998) where it was suggested that the total emissions of $\mathrm{CO}_{2}$ from the construction of office buildings (construction emissions and initial embodied emissions) was seen to vary from 650 to $1100 \mathrm{~kg} / \mathrm{m}^{2}$, with an average value of $790 \mathrm{~kg} / \mathrm{m}^{2}$ (Suzuki \& Oka, 1998). 


\subsubsection{Recurrent embodied energy and recurrent embodied $\mathrm{CO}_{2}$ emissions accounted for in buildings}

Recurrent embodied energy is the energy required to refurbish and maintain a building over its effective life. Cole and Kernan (1995) found that recurring embodied energy is as relevant as initial embodied energy. For a building with a 50 year effective life and conventional energy standards in Canada, 1995, the recurring embodied energy is approximately the same as the initial embodied energy.

The research found that for a life-cycle of 50 years, the recurring embodied energy of the buildings studied is between 6.5 and $6.8 \mathrm{GJ} / \mathrm{m}^{2}$, representing $5-10 \%$ of the office buildings life-cycle energy consumption (Cole \& Kernan, 1996). The summary of the initial and recurrent embodied energy plus operational energy for one of the case studies in that research can be seen in Table A.4 (Appendix A.2).

Table 2.4 shows a summary of recurring energy and $\mathrm{CO}_{2}$ emissions of the buildings analysed in this thesis.

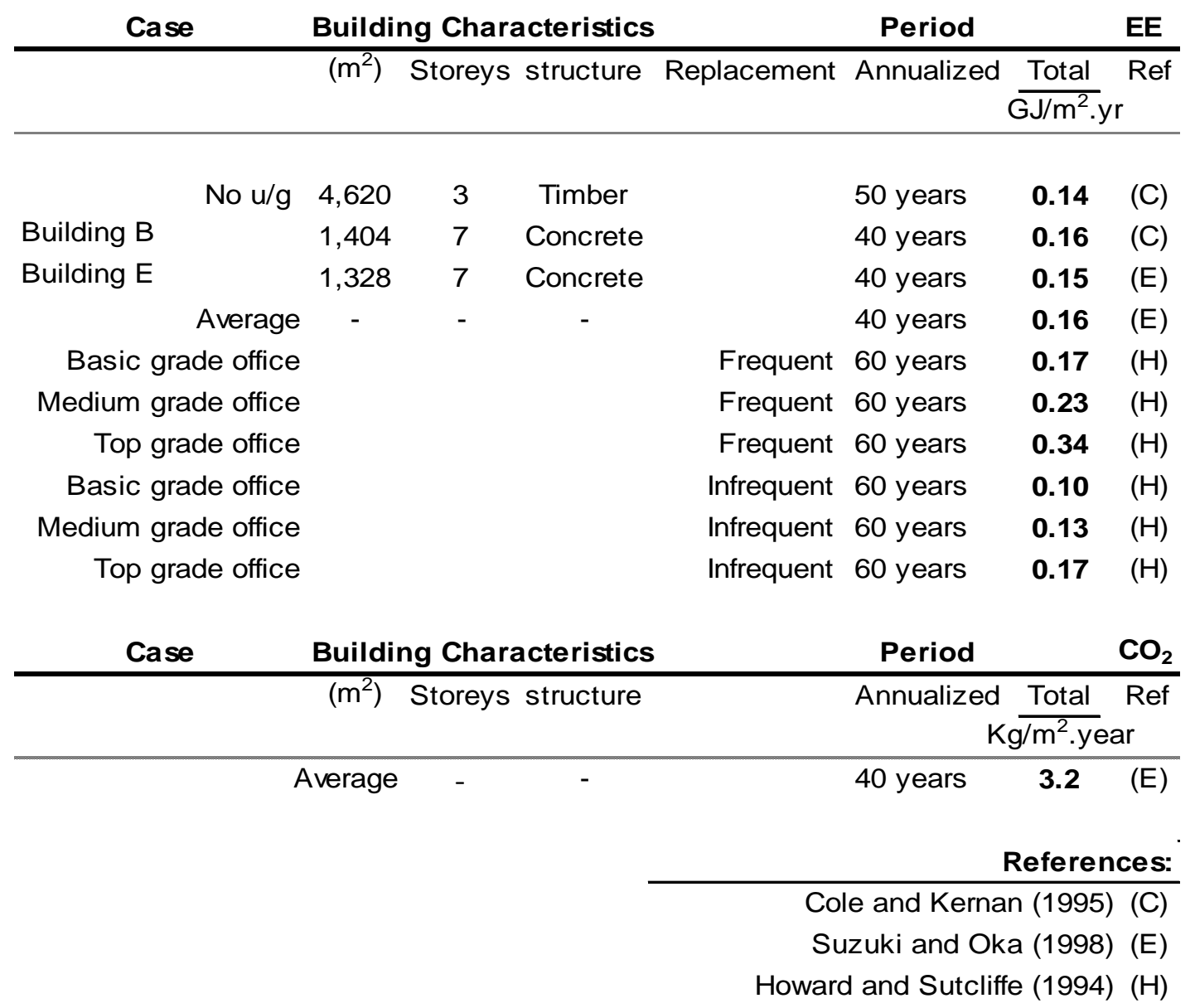

Table 2.4: Summary of recurring energy and $\mathrm{CO}_{2}$ emissions of the buildings analysed in the previous section.

The figures suggested by Howard and Sutcliffe (1994) in table 2.4 are for recurrent embodied energy figures associated with a basic, medium and top graded office fit-out as: internal partitions and doors, floor, wall and ceiling finishes, and mechanical and electrical services. It can also be suggested from Howard and Sutcliffe's (1994) study that recurrent embodied energy might be greater than that associated with initial embodied energy. 
In Suzuki and Oka (1998) the life of the building was set at 40 years. The expected life duration for each of the building materials were hypothetically fixed. The minimum recurring embodied energy consumption in total renovation work was $1.0 \mathrm{GJ} / \mathrm{m}^{2}$ and the maximum was $2.6 \mathrm{GJ} / \mathrm{m}^{2}$. The recurring embodied energy in the renovation work in average was $1.54 \mathrm{GJ} / \mathrm{m}^{2}$ and the average recurring embodied $\mathrm{CO}_{2}$ emission annualised from a 40 year building life was $3.2 \mathrm{Kg} / \mathrm{m}^{2}$ (Suzuki \& Oka, 1998). 


\subsection{Structure and finishes embodied energy and embodied $\mathrm{CO}_{2}$ emissions}

This section groups the data from researches where the initial embodied energy has been broken up into buildings' elements. Breaking up is mainly into structural and finishing elements, but other segregations are also presented depending mostly upon the author's preferences and background. Table 2.5 shows the summary of total initial embodied energy subdivided by structural and non-structural components. There is no information available about embodied $\mathrm{CO}_{2}$ emissions segregated in buildings' components.

\begin{tabular}{|c|c|c|c|c|c|c|c|c|}
\hline & \multicolumn{3}{|c|}{ Building Characteristics } & \multicolumn{5}{|c|}{ Embodied energy } \\
\hline \multirow[t]{2}{*}{ Size $\left(m^{2}\right)$} & \multirow[t]{2}{*}{ Storeys } & \multirow[t]{2}{*}{ structure } & \multirow{2}{*}{$\frac{\text { Structure }}{\mathrm{GJ} / \mathrm{m}^{2}}$} & \multicolumn{3}{|c|}{ Non-structure } & \multirow{2}{*}{$\frac{\text { Total }}{\mathrm{GJ} / \mathrm{m}^{2}}$} & \multirow[t]{2}{*}{ Ref } \\
\hline & & & & $\%$ & $\mathrm{GJ} / \mathrm{m}^{2}$ & $\%$ & & \\
\hline 8,568 & 5 & Concrete & 3.84 & 59 & 2.62 & 41 & 6.46 & (A) \\
\hline 8,568 & 5 & Steel & 5.00 & 65 & 2.75 & 35 & 7.75 & (A) \\
\hline 2,400 & 3 & Concrete & 2.31 & 49 & 2.44 & 51 & 4.75 & (A) \\
\hline 2,400 & 3 & Timber & 1.05 & 31 & 2.3 & 69 & 3.35 & (A) \\
\hline Ave & $3-8$ & Timber & 1.50 & 41 & 2.2 & 59 & 3.7 & (B) \\
\hline Ave & $3-8$ & Steel & 4.40 & 67 & 2.2 & 33 & 6.6 & (B) \\
\hline Ave & $3-8$ & Concrete & 3.40 & 61 & 2.2 & 39 & 5.6 & (B) \\
\hline 4,620 & 3 & Timber & 0.92 & 20 & 3.62 & 80 & 4.54 & (C) \\
\hline 4,620 & 3 & Steel & 1.48 & 29 & 3.65 & 71 & 5.13 & (C) \\
\hline 4,620 & 3 & Concrete & 1.17 & 24 & 3.62 & 76 & 4.79 & (C) \\
\hline 4,620 & 3 & Timber & 0.67 & 16 & 3.6 & 84 & 4.26 & (C) \\
\hline 4,620 & 3 & Steel & 1.22 & 25 & 3.63 & 75 & 4.86 & (C) \\
\hline 4,620 & 3 & Concrete & 0.93 & 21 & 3.58 & 79 & 4.52 & (C) \\
\hline 69,622 & 3 & Concrete & 5.00 & 47 & 5.70 & 53 & 10.7 & (D) \\
\hline 326,766 & 7 & Concrete & 7.00 & 59 & 4.90 & 41 & 11.9 & (D) \\
\hline 754,537 & 15 & Concrete & 9.90 & 61 & 6.20 & 39 & 16.1 & (D) \\
\hline $1,787,073$ & 42 & Concrete / Steel & 11.70 & 65 & 6.30 & 35 & 18 & (D) \\
\hline $2,388,535$ & 52 & Concrete / Steel & 11.60 & 63 & 6.80 & 37 & 18.4 & (D) \\
\hline 2,000 & 2 & - & 2.25 & 37 & 3.77 & 63 & 6.02 & (G) \\
\hline 2,000 & 3 & - & 1.60 & 30 & 3.77 & 70 & 5.37 & (G) \\
\hline 1,730 & 2 & Concrete & 2.20 & 40 & 3.30 & 60 & 5.5 & (F) \\
\hline \multirow[t]{7}{*}{ Average } & & & 3.77 & 43 & 3.77 & 57 & $\begin{array}{l}7.54 \\
\text { Refere }\end{array}$ & nces: \\
\hline & & & & \multirow{4}{*}{\multicolumn{4}{|c|}{$\begin{array}{l}\text { Honey and Buchanan (1992) } \\
\text { Buchanan and Honey (1994) } \\
\text { Cole and Kernan (1995) }\end{array}$}} & $(A)$ \\
\hline & & & & & & & & (B) \\
\hline & & & & & & & & (C) \\
\hline & & & & & & & & (D) \\
\hline & & & & \multirow{2}{*}{\multicolumn{4}{|c|}{$\begin{array}{r}\text { Oppenheim and Treloar (1996) } \\
\text { Aye et al (2000) }\end{array}$}} & $(F)$ \\
\hline & & & & & & & & (G) \\
\hline
\end{tabular}

Table 2.5: summary of initial embodied energy subdivided by structural and non-structural components, data from cases in the previous section.

As can be seen in Table 2.5, structural initial embodied energy accounts for an average of $43 \%$ of the initial embodied energy; non-structural embodied energy, including finishing materials, accounts for the remaining $57 \%$ of total embodied energy.

Non structural embodied energy is normally the single largest component of the initial embodied energy of an office building. Structure normally lasts the full life of the building without requiring replacement or major repairs. Finishes, on the other hand, despite not being a large component of the initial embodied energy, 
normally dominate the recurring embodied energy (Aye et al., 1999; Cole \& Kernan, 1996; Oppenheim \& Treloar, 1995; Treloar et al., 2001).

In Treloar et al. (2001), the total embodied energy was broken down into the following individual components: foundations, structure, internal and external enclosures, and finishes. Table A.5 (Appendix A.2) explains the different groups of elements in all of the case studies, and the individual elements that are contained in the main group of elements. The results show that the embodied energy of structural elements is indeed associated with building height. Other elements such as windows, roof and finishes seem to vary irrespective of building height. Structure ranges from $64 \%$ to $90 \%$ of the initial embodied energy. Finishes range from $3 \%$ to $8 \%$ (Treloar et al., 2001).

In the analysis of the two storey, $1,730 \mathrm{~m}^{2}$ office building in Oppenheim and Treloar (1995), the total embodied energy was broken down into individual components, which were classified into the 14 major components as follows: roof, windows, upper floors, substructure, external walls, floor finishes, ceiling finishes, wall finishes, staircase, columns, internal screen, internal walls, external doors and internal doors. The results show that the roof contains $25 \%$ and windows contain $20 \%$ of the embodied energy of the first 14 elements. The finishing elements, when added together, make up 15.5\% of the total embodied energy and the remaining $39.5 \%$ is comprised mainly in the substructure, external walls, staircases and columns (Oppenheim \& Treloar, 1995).

The most significant individual component was the window frames, which contained 7.33 tons of aluminium. A typical square meter window unit would embody around $3.43 \mathrm{GJ}$ where in comparison, a square metre of insulated brick veneer wall would embody around $1.8 \mathrm{GJ}$. The energy efficient features of this 'low energy' building have a low impact on the total embodied energy. This energy efficient features added only $6.8 \%$ of the embodied energy of the building (totalling $0.38 \mathrm{GJ} / \mathrm{m}^{2}$ ) (Oppenheim \& Treloar, 1995).

\subsubsection{Structure and finishes embodied energy in a concrete, steel and timber building}

In Cole et al. (1996), initial embodied energy of the proposed timber, steel and concrete buildings is broken up into the following: site work, structure, envelope, finishes, services and construction of the building. Table A.6 (Appendix A.3) shows the summary of the initial embodied energy by components of the wood, steel and concrete buildings (Cole \& Kernan, 1996).

The research states that the choice of building envelope is invariably linked with the structural system. That combination of building envelope and structural system represents $48.6,54.1$ and $50.7 \%$ of the total embodied energy of the timber, steel and concrete structures respectively (Cole \& Kernan, 1996). But when envelope and structural systems are segregated, envelope represents the largest single component of the total initial embodied energy. Envelope represents between $26 \%$ and $30 \%$ of the total embodied energy and structural systems represent $15.7,25.2$ and $20.6 \%$ of the total initial embodied energy for the wood, steel 
and concrete framed buildings respectively. The internal finishes consume between $12 \%$ and $15 \%$ of the initial total embodied energy. Finally, the research includes the initial embodied energy of services, being between $20 \%$ and $25 \%$ of the total embodied energy (Cole \& Kernan, 1996).

Over a buildings life-cycle of 50 years, the initial embodied energy of the structure represents a relatively small portion of its life-cycle embodied energy (less than 5\%). As a consequence, the distinction between structures made of concrete, steel and timber is less marked (Cole \& Kernan, 1996, p. 317). 


\subsection{Demolition energy consumption and demolition $\mathrm{CO}_{2}$ emissions}

Demolition energy is the energy used to demolish buildings and the subsequent transport and disposal of the building's waste materials at the end of its effective life. There is limited information published and it is a process difficult to assess as it is based on the prediction of demolition practice some 50 years, or more, in the future. It can also be difficult to assume an increase in efficiency of demolition and reutilisation of materials during this period of time (Cole \& Kernan, 1996).

Table 2.6 presents data published in Cole and Kernan (1995). It is not clear what parts of the demolition process are included in these figures, for example, does this include just dismantling or does it include transportation?. The study suggests that demolition energy should represent approximately $1 \%-3 \%$ of the initial embodied energy (Cole \& Kernan, 1996).

\begin{tabular}{ll|l|l|} 
& \multicolumn{1}{l}{ Timber } & \multicolumn{1}{l}{ Steel } & \multicolumn{1}{l}{ Concrete } \\
\hline For a $5000 \mathrm{M}^{2}$ building & $27.1 \mathrm{MJ} / \mathrm{m}^{2}$ & $81.7 \mathrm{MJ} / \mathrm{m}^{2}$ & $136.2 \mathrm{MJ} / \mathrm{m}^{2}$ \\
\hline
\end{tabular}

Table 2.6: The U.S, Advisory Council on historic preservation energy use in demolition (Cole \& Kernan, 1996).

Suzuki and Oka (1998) suggest that energy consumption is $0.49 \mathrm{GJ} / \mathrm{m}^{2}$ and $\mathrm{CO}_{2}$ emissions are $36 \mathrm{~kg} / \mathrm{CO}_{2}$ from the demolition of a reinforced concrete office building. Both studies in this section agree that energy consumption and $\mathrm{CO}_{2}$ emissions from the demolition work contributes a relatively small amount to their respective totals (Cole \& Kernan, 1996; Suzuki \& Oka, 1998). 


\subsection{Embodied energy and $\mathrm{CO}_{2}$ emissions in 'Iow-energy' buildings}

As was stated in Section 2.2, for buildings that comply with conventional energy performance standards, operating energy is by far the largest component of the life-cycle energy use. It is normally larger than the construction energy, initial embodied energy, recurrent embodied energy and demolition energy combined (Aye et al., 1999; Cole \& Kernan, 1996; Oppenheim \& Treloar, 1995; Page, 2006; Suzuki \& Oka, 1998). In Cole and Kernan (1995) for example, operating energy represents between $80 \%$ to $90 \%$ of the life-cycle energy use. The figures vary depending mainly on the climate where the building is placed.

Due to the relatively small incidence of embodied energy into the buildings life-cycle energy consumption, there is a lack of interest in this particular field of research. The following paragraph published in (Oppenheim \& Treloar, 1995) discusses the state of the research related to the influence of embodied energy into the life-cycle energy use of buildings:

"In both Australia and overseas, it appears that the field of embodied energy analysis is generally still only of academic interest. There is little interest in the market place for undertaking of these calculations and the design changes that would follow from the results produced. Additionally, no country yet has embodied energy regulations. Accurate knowledge is hard to find, and it is rare to find calculations done during the design process".

Nevertheless, as was observed in Cole and Kernan (1995), when more efficient energy standards are applied, buildings' embodied energy and recurrent energy became more significant. Further to this matter, (Treloar et al., 2001) state that: "several studies have shown that for office buildings, embodied energy can be quite significant, especially for energy efficient design in temperate climate". Oppenheim and Teloar (1995) found for one case, a 'low energy' building, that the embodied energy represents between 21. and 37 years of operational energy.

Table 2.7 presents the final amount of energy use in operations within the life-cycle energy consumption. Two consecutive percentages of energy in operations reduction ( $50 \%$ and $75 \%$ reduction) are assumed for a typical building life of 50 years.

1995 Canadian standard of energy use (50 years)

Assuming 50\% reduction of operational energy

Assuming $75 \%$ reduction of operational energy

\begin{tabular}{|c|c|}
\hline Vancouver & Toronto \\
\hline $80 \%$ & $90 \%$ \\
\hline $70 \%$ & $80 \%$ \\
\hline $55 \%$ & $65 \%$ \\
\hline
\end{tabular}

Table 2.7: Assumption of energy in operation reduction and its weight in life-cycle energy use

For a conventional building, operating energy represented approximately $80 \%$ of the life-cycle energy consumption in Vancouver and $90 \%$ in Toronto. When operational energy was reduced by $75 \%$, this would represent $55 \%$ of the life-cycle energy consumption in Vancouver and $65 \%$ in Toronto (with underground parking) (Cole \& Kernan, 1996, p. 314). In this research it is stated that if operational energy is reduced to 
below $50 \%$ of current usage, embodied energy will become a more influential factor. When operational energy has been reduced, the emphasis should then be directed at reducing a building's embodied energy (Cole \& Kernan, 1996).

\subsection{Assessment of the differences between concrete, steel and timber buildings}

Cole and Kernan (1996) analysed three buildings with a structural system built of timber, steel and concrete respectively and that comply with the proposed Canadian 1995 National Energy Code. The research found that the differences in operational energy between a wood, steel and concrete framed building is negligible.

Regarding the insensitivity between the structural options energy use performance, Cole and Kernan (1996) states that office buildings tend to be internal load-dominated, and their operating energy less dependent on the thermal characteristic of the building. It is also suggested that the major influence on operating energy resulting in differences between a wood, steel or concrete structural frame would be the change in thermal mass. However, the alternative designs have common interior finishes and concrete toppings on the floors. These are typically the most dominant factors affecting the effective thermal mass of the building, rather than the underlying structure (Cole \& Kernan, 1996).

Page (2006) on the other hand, found that initial and recurrent energy was lower for the timber design than the other two materials; and initial and recurrent embodied $\mathrm{CO}_{2}$ emissions of timber were two to three times lower than for the steel or concrete building. However, when the effect of operating energy consumption is added to the comparison the picture changes, with the timber design now the highest user of energy and steel the lowest producer of $\mathrm{CO}_{2}$ with an overall difference between the three designs of only about $3 \%$.

When looking at embodied energy, Cole and Kernan (1995) found that the difference between the initial and recurrent embodied energy of a concrete, steel and timber framed building, designed to have similar performance, can be significant. On the other hand, it was also found that the use of concrete in foundations, undergrounds and floor toppings, normally tempers that distinction. For example when underground parking is added to the comparison this increases the structural embodied energy to $38 \%, 21 \%$ and $25 \%$ for the wood, steel and concrete structure respectively (Cole \& Kernan, 1996). But structural systems are rarely built from a single material type; normally structural systems involve a series of different materials in assembly choice and even in secondary and non-structural elements (Cole \& Kernan, 1996; Page, 2006).

Regarding this matter, Page (2006) states: "Each design used mainly one material for the structural system, however as the report notes, designers tend in practice to mix materials, based on their experience of what has been cost effective in the past. Also, the aesthetics, 'prestige', and environmental impact of the building are often of importance to the owner, and this will influence the choice of materials"(Page, 2006). 
As said before, finishes are indeed of a different material than those used in the structures, and normally involve a large range of different materials. It can be suggested that finishes involve materiality that work relatively well in all concrete, steel and timber structural systems. 
Literature review 


\section{Methodology}

As stated in the introduction, the aim of this thesis is to determine the influence of construction materials on the life-cycle energy use and $\mathrm{CO}_{2}$ emissions of medium sized commercial buildings. To achieve that aim, four commercial buildings were designed, in which the materials for the structures and finishes are predominantly concrete, steel or timber (the fourth building is a variation of the timber building). All the conclusions in this thesis are products of the analysis and discussion of the results produced by the assessment undertaken on each of these four buildings. As will be explained in this chapter, the assessment undertaken on each building is based upon what is commonly known as a Life-cycle assessment. However, in this thesis not all life stages were studied and only some environmental burdens were considered.

In the following section, the great care taken to ensure realistic design of the four buildings used as the case studies in this assessment will be described. This is a great strength of this thesis, in that the process of design of the four buildings was supervised by architects, civil engineers and building scientists. Due to these factors, it is possible to say that all four buildings in this thesis are a fair representation of New Zealand design and construction practices.

It is not only the aim of this chapter to introduce the case studies and assessment method used in this research, but also to introduce all variables in the results and discussions chapter. The research flows from methodology into results, with the former chapter providing the data necessary to understand all results.

Section 3.1 will describe the process of simplification of the initial laboratory building used to produce this research and the final alternative office building used as a case study. Section 3.2 will describe each of the four case studies produced for analysis in this thesis. It contains a description of the structural system and the finished materials used in the concrete, steel, timber and timber-plus buildings.

Section 3.3 will describe the method used to assess the buildings' operating energy and $\mathrm{CO}_{2}$ emissions. This section consists mainly of the description of the method used in the operating energy simulations. Describing the HVAC system uses the schedules for simulation and a detailed description of the buildings' thermal envelope. Finally, in Section 3.3, the $\mathrm{CO}_{2}$ factors for the conversion into $\mathrm{CO}_{2}$ emissions of the gas and electricity consumed during the operations of the buildings in this research will be introduced.

Section 3.4 will start introducing the scope of LCA and from that, will introduce which of the life stages and environmental burdens will be studied in this thesis. Section 3.4 will also describe the method of calculation of buildings' embodied energy and embodied $\mathrm{CO}_{2}$ emissions. It includes the quantities of materials measurement and the production of the maintenance schedule for recurrent energy calculation.

Finally Section 3.5 introduces the two databases of buildings' materials embodied energy and $\mathrm{CO}_{2}$ emissions used in this research. Special care will be given in the explanation of the differences between both databases and to introduce how these differences will determine the two different sets of embodied energy and embodied $\mathrm{CO}_{2}$ emissions results. 


\subsection{Building design}

This section introduces the development of the case studies on the buildings. It will introduce the original building used as a model from which the concrete, steel, timber and timber-plus buildings were produced.

The buildings analysed in this research are based on an actual building, a new six-storey, $4250 \mathrm{~m}^{2}$ (gross floor area) laboratory for the School of Biological Sciences at the University of Canterbury in Christchurch. It was designed by local architects (Courtney Architects) with reinforced concrete as the main material for structure, envelope walls, floors and roof slabs. Figure 3.1: Shows a perspective view.

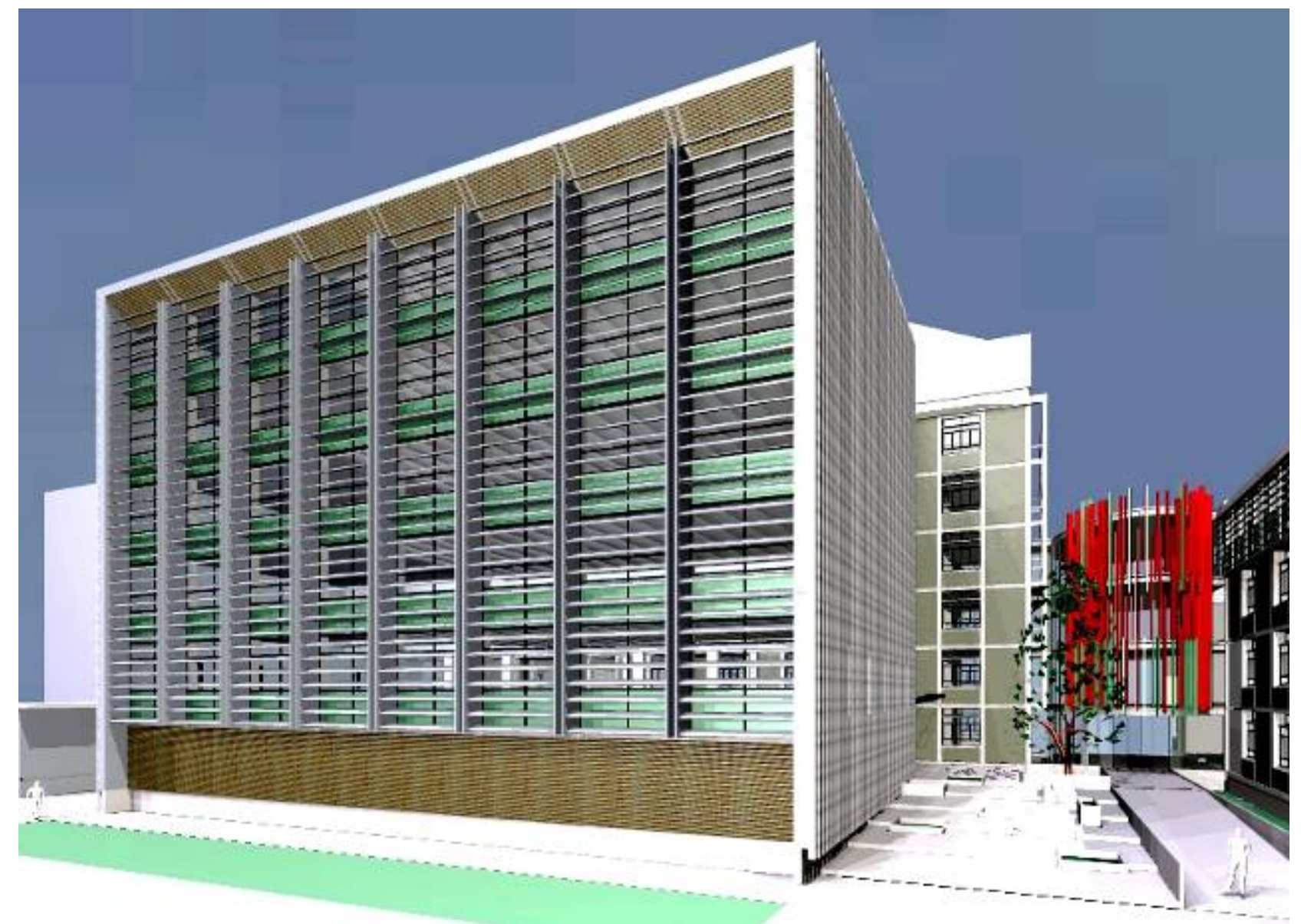

Figure 3-1: Perspective view of the laboratory building of the School of Biological Science.

It can be seen that the front façade is a glass curtain wall shaded by horizontal external aluminium louvres. The laboratory building is surrounded by other buildings at the University of Canterbury, specifically the Zoology building, which shares a large covered atrium (not visible in this image). The laboratory building is part of a much bigger complex of buildings.

Figure 3.2 shows the Level 4 floor plan of the building, including the North façade of the adjacent Zoology building and the atrium between both buildings. It is possible to see three main buildings attached to each other. First is the laboratory building (rectangle area at the left of Figure 2), second is the atrium (middle rectangle) with the stairs, lift and corridors, and finally the Zoology building (the long rectangle at the right in 
Figure 3.2). The complexity of the layout of the laboratory building of the School of Biological Science can be seen. This complexity is because, as this is designed as a laboratory, each floor requires a programme in which various cubicles enclose different facilities such as: microscopy, incubators, wet room, freezers, and fridges. Opposite the cubicles are the research labs, placed close to the North façade (curtain wall) and subdivided into wider rooms.

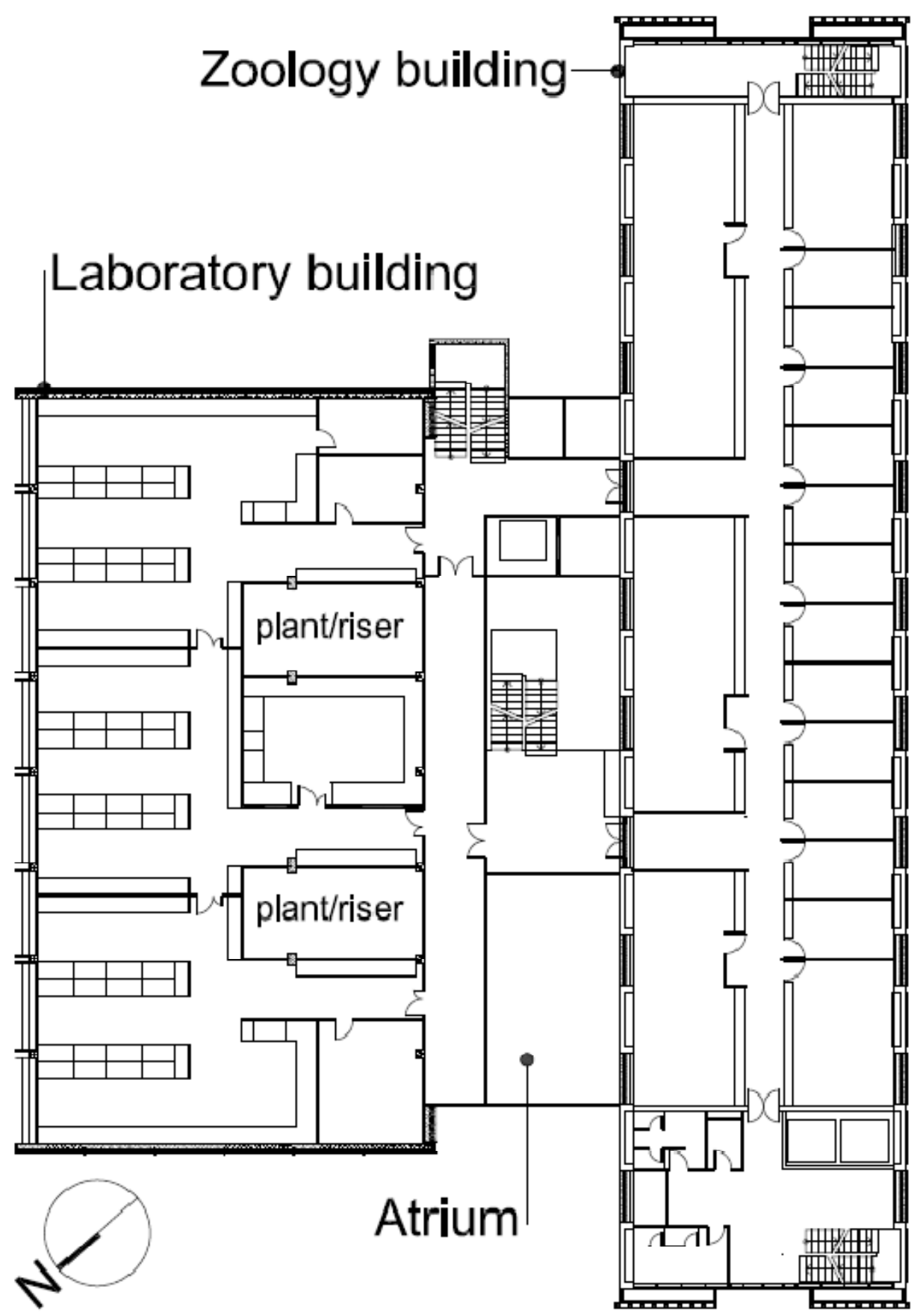

Figure 3-2: Level 4 - floor plan of the School of Biological Science building and Zoology building with atrium in between, connecting both buildings.

The presence of 'plant/riser duct' is also significant; these are two enclosed void areas closed to the South façade. Each void is approximately $8 \mathrm{~m}$ by $4 \mathrm{~m}$ and the length of these is placed transversally to the laboratory building. Finally, the presence of the atrium area between the laboratory building and the existing 
School of Zoology is important in this drawing. This atrium contains all the corridors, stairs and services areas (lift and bathrooms) of the laboratory building, and connections with the zoology building.

\subsubsection{Alternative buildings}

The initial laboratory (concrete) building was used by the author to produce architectural and structural drawings for four further versions in which the structures and finishes are predominantly concrete, steel or timber. Figure 3.3 shows the simplified plan section used for the fourth case study produced in this research.
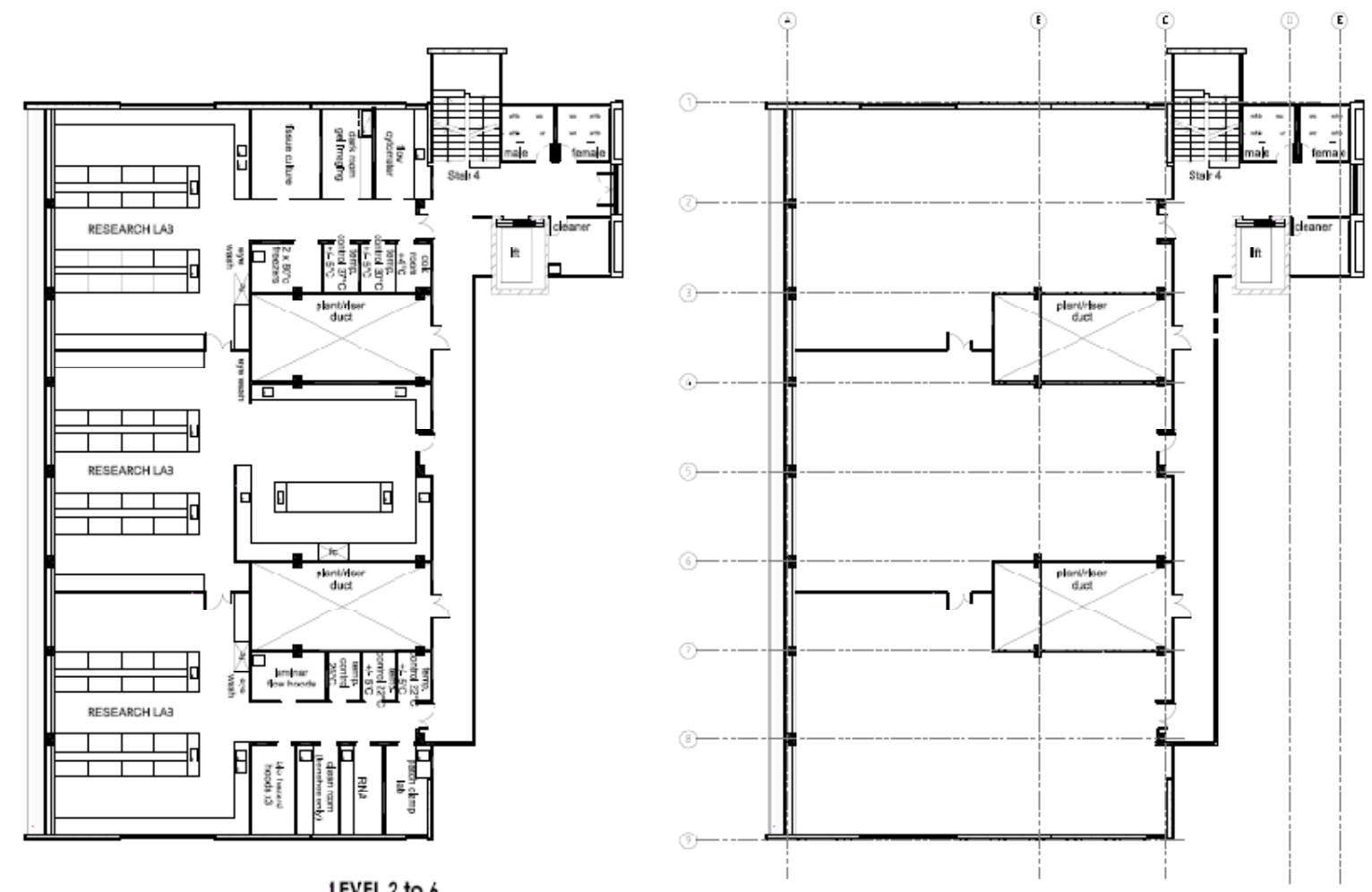

LEVEL 2 to 6

Figure 3-3: Plan of the simplified layout used in the concrete, steel, timber and timber-plus buildings.

The case studies were designed as stand-alone buildings, keeping the same original orientation but not including the zoology building and the atrium connecting both buildings. The original building is approximately $40 \mathrm{~m}$ by $20 \mathrm{~m}$ in plan with one set of stairs and one elevator. The four case studies are based on the same simplified version of the initial laboratory building. This is shown in Figure 3.3 where the standalone laboratory building is compared with the plan of the alternative concrete building. The part of the atrium that contains the stairs, lift, bathrooms and corridors, remains attached to the alternative building. 
This project uses four case study buildings:

Concrete building

Steel building

Timber building

Timber-plus building

All four alternative buildings are designed as the same simple commercial building with open plan floor spaces rather than the complex laboratory building layout shown in Figures 3.2 and 3.3. The concrete building has the same reinforced concrete structure and the same cladding as the real building, but openplan commercial floor areas. The steel and timber buildings use structural steel and structural timber as the main materials for structure and many of the finishes. For the steel and timber buildings, one of the objectives was to use as much of the target material as reasonably possible, both in the structure and finishes. In order to maintain 'common practice', many interior and exterior finishes materials are common to the concrete, steel and timber designs. For example, windows, curtain walls in the North and South façade, sun louvres in the North façade, roof cladding and internal finishes such as most of the linings and ceilings are the same for all three initial case studies.

A fourth building was produced, in which all possible 'common finishes' were replaced by timber components. This was done for the timber building and has been labelled as Timber-plus. It was included to assess the influence of using timber for the 'common finishes' which might be expected to have a lower total embodied energy and embodied $\mathrm{CO}_{2}$ emission. This will help to assess the influence of finishes in the lifecycle energy use and life-cycle $\mathrm{CO}_{2}$ emissions.

\subsection{Building description:}

This section introduces in detail the concrete, steel, timber and timber-plus buildings. Firstly it will introduce the common architectural design of all four buildings and then it will approach individual differences between all four buildings. For each of the four buildings this section will introduce the structural configuration and the finished material.

In all four case studies the buildings' envelope walls are the same at the East, and at the West ends all four have solid walls with only two narrow windows, one vertical (South corner) and one horizontal window centred in the façade. The North façade is a curtain wall made of double glazed windows framed in aluminium mullions and transoms. The aluminium louvres outside the curtain wall cover all the façade from the ground floor up to the roof 'soffit'. The North façade construction is the same for the concrete, steel and timber buildings. For the timber-plus building the North façade double glazed windows have composite timber-aluminium frames. The timber choice was imported Canadian cedar, which was also used for mullion and transom and in all parallel louvres outside the curtain wall. Louvres outside the North façade cover the same area as in the concrete, steel and timber buildings and are supported in a cedar timber structure. 
The South side has an external corridor that connects the offices with the stairs, lift and toilet service area (see Figure 3.5). Corridors are enclosed between a light wall (South façade of internal offices) and a single glass aluminium framed curtain wall (South façade of building). The south façade curtain wall is the same for the concrete, steel and timber buildings but different for the timber-plus building where the single glazed curtain wall is framed in cedar joinery. Figure 3.4 shows the North-east façades perspective view of the alternative concrete building.

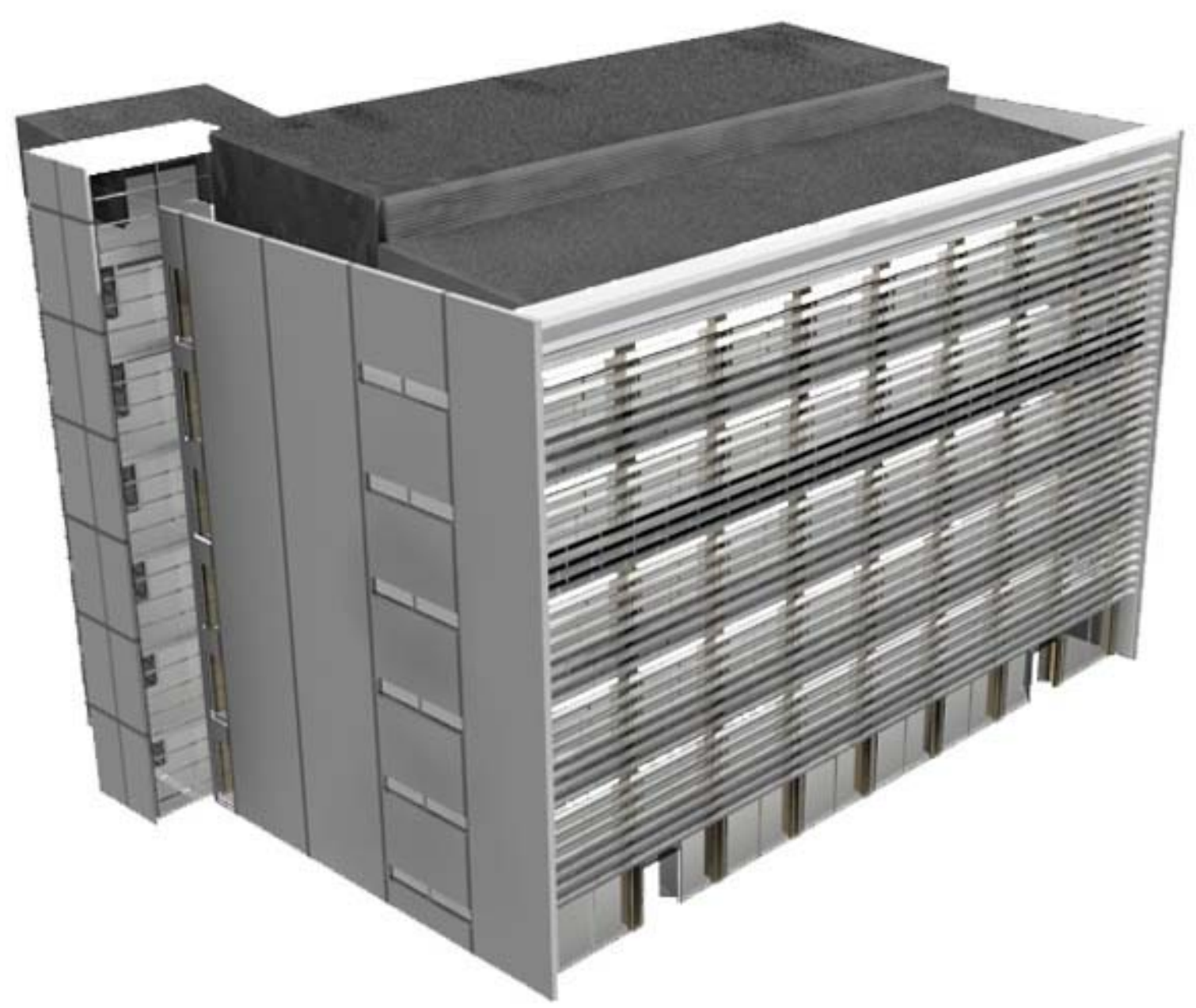

Figure 3-4: North-east façades perspective view of the alternative concrete building North façade.

The overall architectural design is the same in all four buildings but built in different materials and using different building techniques. Figure 3.4 shows the North-east perspective view of the concrete building where it is possible to identify the layout of the North facing curtain wall behind the parallel louvres. Also visible are the seven structural columns from the ground floor up to roof slab. The East facing wall is the same as the West facing wall and it is possible to see the stairwell coming out of the service area in the South end of the East facing wall. The stepped shape of the roof is due to the plant room, which increases the roof heights on the south side. Inside the plant room, chimneys exhaust the air from the offices when these are being naturally ventilated. The roof top plant room has a combination of profiled metal cladding and operable aluminium louvers attached to the walls, which will allow the heat to be expelled when not required. Figure 3.5 shows the South-west façades perspective view of the alternative concrete building. 


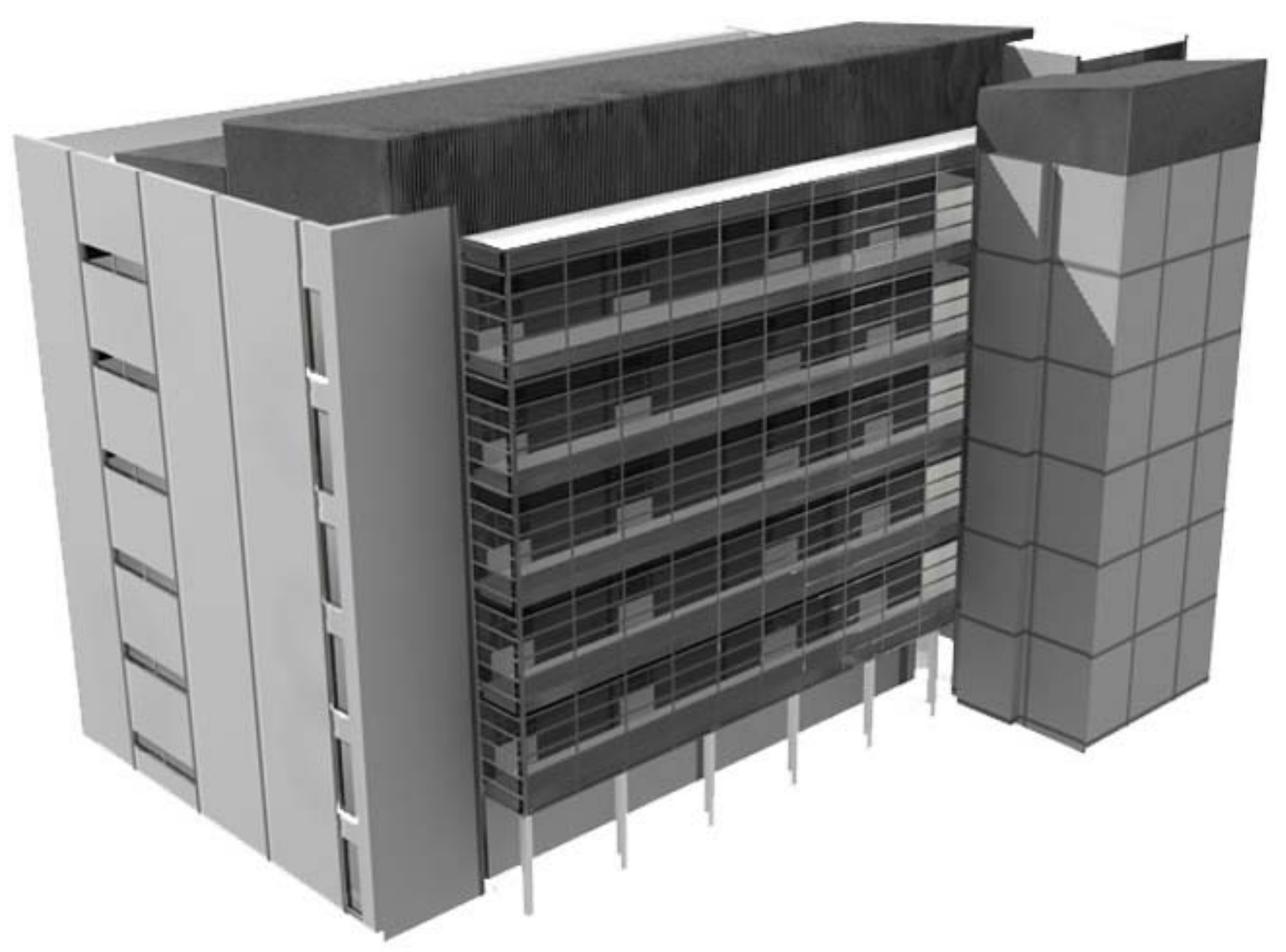

Figure 3-5: South-west façades perspective view of the alternative concrete building.

It can be seen in Figure 3.5 that the South-facing corridors are covered in a single glass curtain wall. This corridor connects the service area in the East end with each of the three office areas inside the main body of the offices. The service area envelope wall is made of reinforced concrete and has steel sheet profiles as roof cladding. The South facing envelope wall runs inside the corridors enclosing the main body of offices. 


\subsubsection{Concrete building:}

The concrete building is a reinforced concrete column and beam structure. The building is raised floor by floor with shear concrete walls at each end of the building. Rectangular columns and beams form a frame on the North and South faces. Internal beams are supported on one internal row of columns spanning approximately $12 \mathrm{~m}$ from the North edge and $6 \mathrm{~m}$ from the South edge. These support the long span precast floor unit (see Figure 3.6).

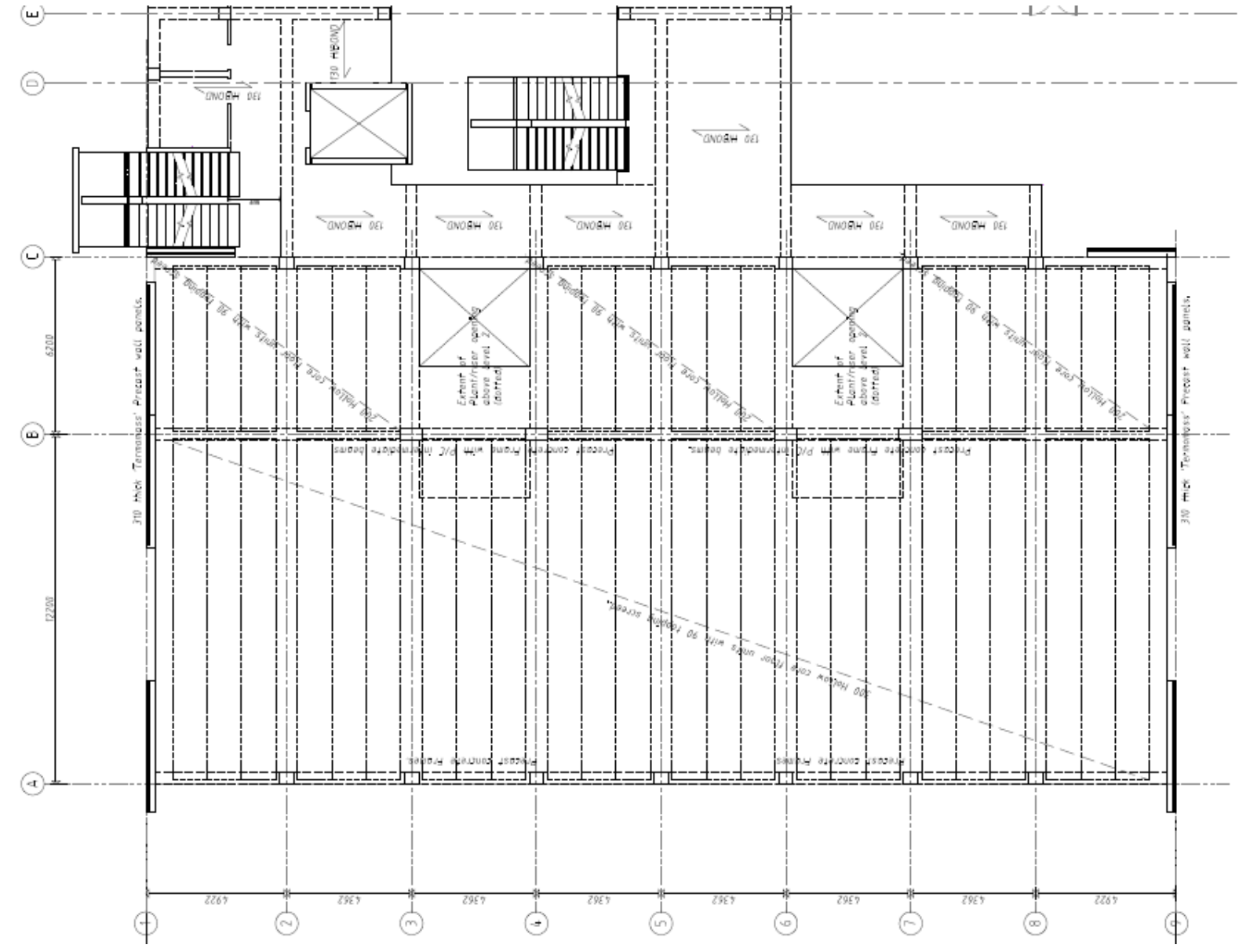

Figure 3-6: Structural floor plan of the laboratory building including the atrium structure (not included in the concrete building alternative version).

The floors are precast 'hollowcore' floor slabs supported by the frame beams. The thickness of the hollowcore slabs range from $200-300 \mathrm{~mm}$ plus $75 \mathrm{~mm}$ reinforced concrete topping. Two openings for vertical chimneys are left in all floors. The roof is formed using the same precast units as the upper floors, complete with topping system. Over this structure a lightweight timber and steel framed roof is built with metal roofing. The roof plant room is constructed from timber and steel and is clad in the same material as the roof.

The East wall, West wall and part of the South façade are made of $310 \mathrm{~mm}$ thick 'Thermomass', which is a composite wall with $60 \mathrm{~mm}$ concrete on the exterior, $50 \mathrm{~mm}$ of extruded polyurethane insulation in the core, 
and $200 \mathrm{~mm}$ of exposed reinforced concrete in the interior of the building. The service area walls are $200 \mathrm{~mm}$ reinforced concrete walls (CTC Composite technologies corporation, 2008). The light weight walls on the south face of the offices and the walls to the ventilation chimneys are timber framed walls containing $90 \mathrm{~mm}$ thick fibreglass insulation and a $25 \mathrm{~mm}$ air cavity for the exterior walls. For internal finishes, the timber framed walls are lined with Gib plasterboard. Acoustic insulation is required between partitions of the main body of offices. Generally, a plaster acoustic tiled ceiling is used in all office areas. The solid concrete exposed walls have a clear sealer applied; plasterboard walls have a paint finish and all precast concrete walls have an external finish.

\subsubsection{Steel building:}

Figure 3.7 shows the North-east and South-west perspective views of the steel building. The steel building consists of a concrete slab supported on steel beams and columns. Both internal and external walls are nonstructural elements, being a light weight steel stud wall supported between floors. This is the only design in which the East and West end envelope walls are not part of the structural system. As described in section 3.3 (Building Description) both curtain walls in the North and South façade are the same as in the concrete and timber buildings.
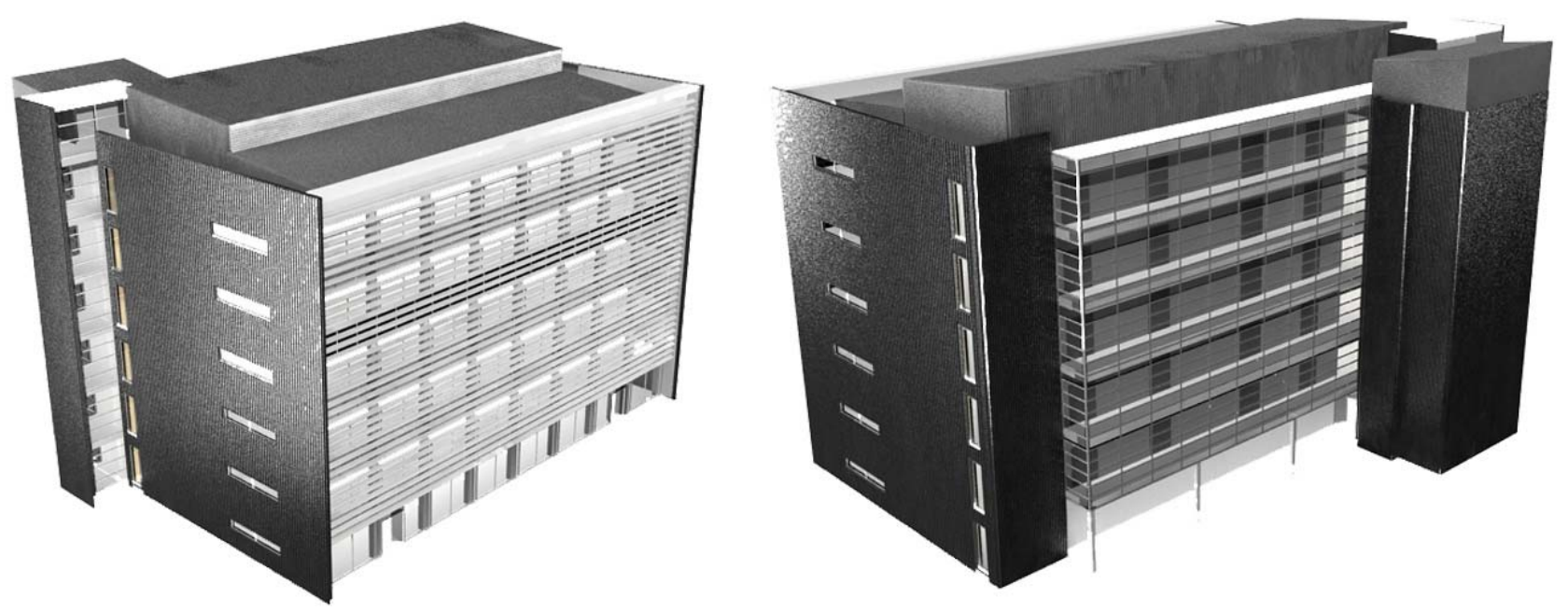

Figure 3-7: Steel building, North-east and South-west perspective views.

Structurally the steel building is a column and beam steel structure braced by Eccentrically Braced Frames (EBFs). The structural layout is shown in Figure 3.8; there are three frames of columns and beams running along the building, one at each long edge and one internal frame. Transverse secondary beams connect the three longitudinal frames. The floors are braced by EBFs. There are two frames in the longitudinal direction located at the perimeter of the building. There are four frames in the transverse direction inside the building, located beside the chimney voids.

The floors and roof slab use the Comflor system, where a $0.9 \mathrm{~mm}$ corrugated galvanized steel sheet supported by the structural beams, is topped by $150 \mathrm{~mm}$ of reinforced concrete with a total floor depth, floor plus beam, of typically $610 \mathrm{~mm}$. The roof slab is formed using the same Comflor system complete with concrete topping and a $75 \mathrm{~mm}$ thick fibreglass insulation layer below the steel deck. Over this structure a 
steel framed roof is built with metal roofing. The roof plant room is constructed of steel frames and is clad in the same material as the roof. Figure 3.8 shows one of the sketches provided by Steel Construction New Zealand (Xiao \& Fussell, personal communication, September 6, 2007). This sketch gives the proposed layout of the steel structure recommended for the simplified steel building.

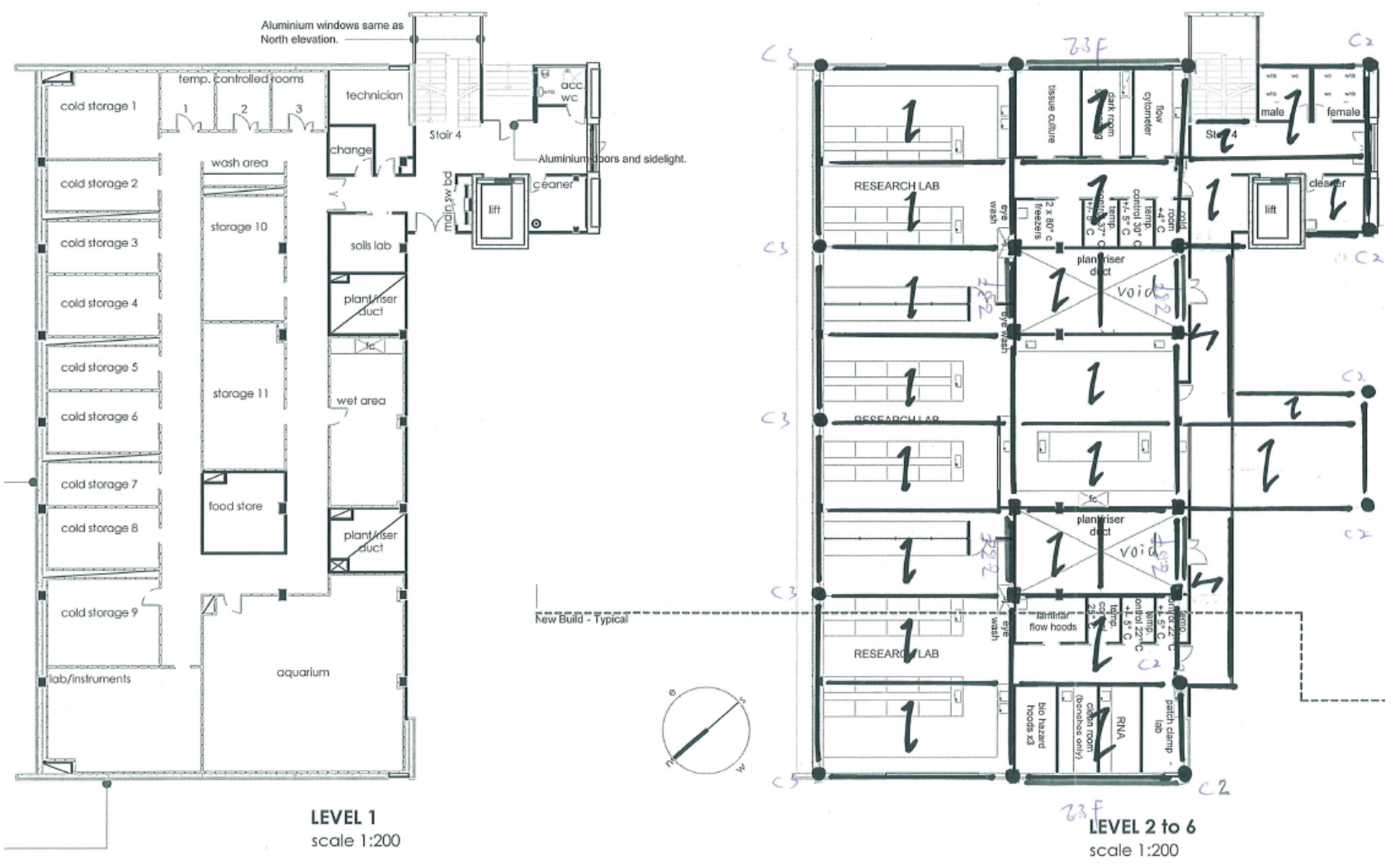

Figure 3-8: Sketches of the layout of the steel building structure compared with the layout of the concrete structure.

The envelope walls at each end of the building and around the service shaft have been assumed to be nonstructural elements. Walls on the East and South faces are supported between floor slabs, so that the heavy steel structure is exposed inside the building, and hence not able to act as a thermal bridge. The envelope walls in the East, West and South façades (enclosing the main body of offices) are framed in lightweight galvanized steel studs and contain $90 \mathrm{~mm}$ fibreglass insulation. These have a $30 \mathrm{~mm}$ air cavity for ventilation and the cladding is painted steel sheet profile.

Internal partitions are framed in lightweight galvanized steel studs with Gib lining materials, and they contain $90 \mathrm{~mm}$ fibreglass insulation. Acoustic insulation is required between partitions of the main body of offices. Generally, a plaster acoustic tiled ceiling is used in all office areas, and all plasterboard is painted 


\subsubsection{Timber and Timber-Plus buildings:}

The timber and timber-plus buildings are constructed from a new post-tensioned structural timber system being developed at the University of Canterbury (Buchanan, Deam, Fragiacomo, Pampanin, \& Palermo, 2008; Paleremo, Pampanin, Fragiacomo, Buchanan, \& Deam, 2006; Smith, Pampanin, Fragiacomo, \& Buchanan, 2008). The structural timber columns, beams and shear walls are prefabricated from laminated veneer lumber (LVL), and assembled on site with post-tensioned connections. The beams, columns and walls are fabricated from multiple layers of $63 \mathrm{~mm} L V L$ glued together into large prefabricated components. Most beams and columns have a cross section of approximately $400 \times 600 \mathrm{~mm}$. Earthquake resistance and wind resistance is provided by moment-resisting frames in the longitudinal direction and cantilever shear walls in the transverse direction. The moment-resisting frames have post-tensioned beams supported between continuous solid timber columns which are not post-tensioned. The cantilever shear walls have vertical post-tensioning tendons and some yielding steel bars as energy dissipaters at the base.

Figure 3.9 shows a structural slice through one floor of the timber and timber-plus buildings. The columns in the North and South frames and in the centre row can be clearly seen. The centre columns sit on the long edges of the voids. Structural shear walls are visible in the East and West faces and also the module of the prefabricated floor system. Light weight timber framed walls are placed in the spaces between the structural shear walls. All the columns are located in the same position and have similar sizes to the columns in the concrete building.

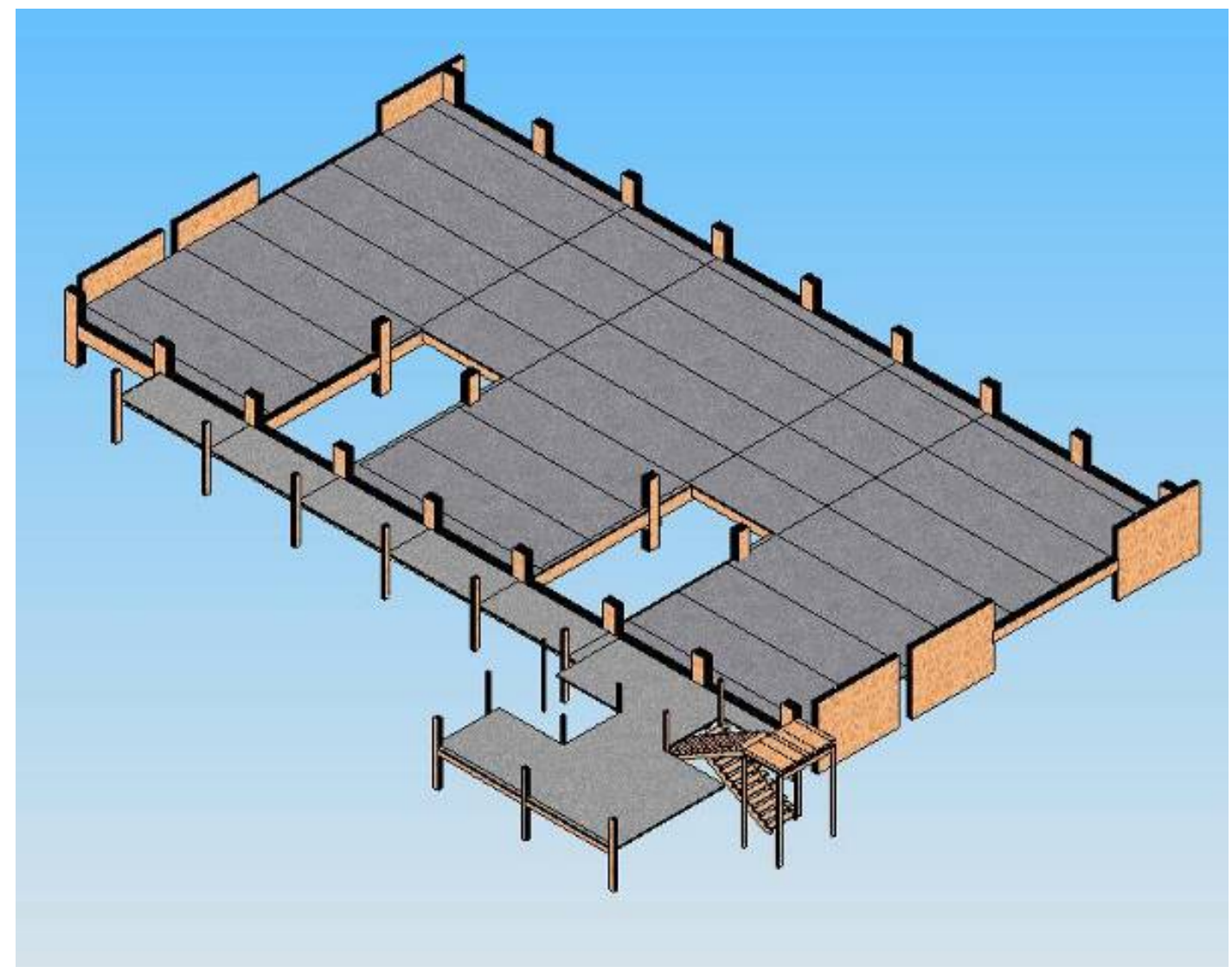

Figure 3-9: Structural slice through one floor of the timber and timber-plus building. 
The structural system that supports the flooring has been altered slightly from that of the original concrete structure, in order to reduce the maximum span from $12 \mathrm{~m}$ to $9 \mathrm{~m}$, as shown in Figure 3.9. The upper floors and the roof slabs are timber-concrete composite slabs built using prefabricated structural plywood and LVL decking supported on four internal structural timber gravity beams and the end walls. The plywood decking supports a $60 \mathrm{~mm}$ thick reinforced concrete composite topping, fixed to the LVL joists by notches and embedded coach screws. The roof slab contains a $75 \mathrm{~mm}$ thick fibreglass layer.

The structural LVL walls in this design are designed as coupled rocking walls. They are located within the East and West envelope walls, so must be considered as potential thermal bridges. The light weight envelope walls are framed in timber studs with $90 \mathrm{~mm}$ fibreglass insulation. The envelope walls (structural walls or light weight walls) have a $25 \mathrm{~mm}$ air cavity for ventilation under the exterior cladding sheet. The light weight envelope walls and the internal partitions are framed in timber studs with 90mm fibreglass insulation and Gib internal linings.

\subsubsection{Timber building finishes}

Figure 3.10 shows the North-east and South-west façade perspective view of the timber building. The North and South curtain walls, external louvres in North façade, roof and plant room claddings, and windows in the East and West façade are the same as in the concrete and steel buildings.
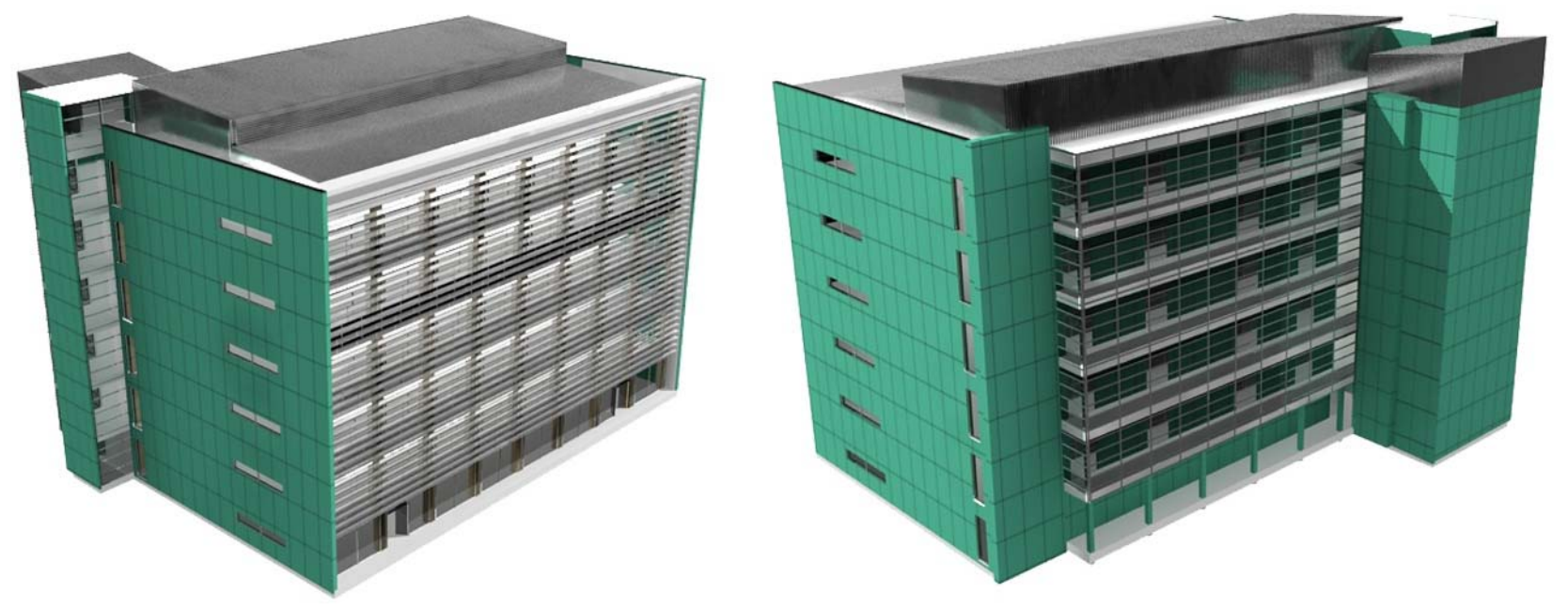

Figure 3-10: Timber building, North-east and South-west perspective views.

The light weight envelope walls in the East, West and South façades (including service area envelope walls), are framed in timber studs with $90 \mathrm{~mm}$ fibreglass insulation. These walls have a $25 \mathrm{~mm}$ air cavity for ventilation built with $25 \mathrm{~mm}$ timber battens under fibre cement sheets used as external cladding. Internal finishes are timber framed walls lined with Gib plasterboard. Acoustic insulation is required between partitions of the main body of offices. Generally, a plaster acoustic tiled ceiling is used in all office areas. 


\subsubsection{Common finishes used in a Timber-plus building}

As explained in Section 3.2.1 (Alternative Buildings), in the timber-plus building, all possible 'common finishes' of the timber building were replaced by timber components in order to maximise the use of wood. Figure 3.11 shows the North-east and South-west perspective views of the timber-plus building. In the timber-plus building all aluminium window frames were replaced by timber (cedar) frames and composite aluminium-cedar frames in the case of operable windows. Timber louvres in the north façade are another important replacement, with the original aluminium windows replaced by cedar louvres supported in a cedar structure with steel connections.

The light weight envelope walls in the East, West and South façades (including service area envelope walls), are framed in timber studs with $90 \mathrm{~mm}$ fibreglass insulation. These walls have a $25 \mathrm{~mm}$ air cavity for ventilation built with $25 \mathrm{~mm}$ timber battens under Radiata pine weatherboards (TDA's flatline board systems, see drawings in attached $C D$ ). Internal linings are MDF (painted) for service and corridor areas, and solid finger jointed timber boards inside the offices. The partitions between the main offices are solid timber walls made of five solid timber layers of Radiata pine with a final thickness of $105 \mathrm{~mm}$. MDF panels with a decorative hardwood veneer are used for ceilings in all office areas.
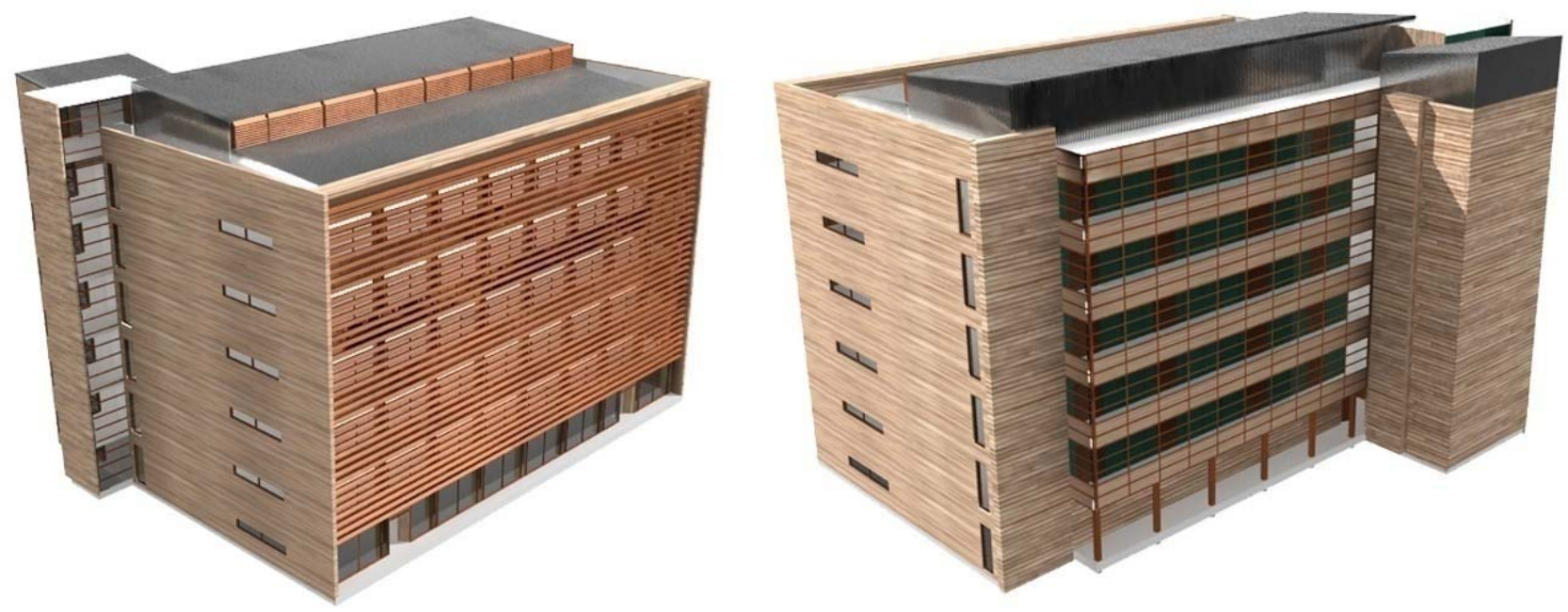

Figure 3-11: Timber-plus building, North-east and South-west perspective views.

Architectural drawings of the steel, timber and timber-plus buildings are provided as complementary material in a $C D$ attached to this thesis. Structural details and external finishes of the concrete building are provided in the original drawings provided by the University of Canterbury consultants for the laboratory building.

Figure 3.12 shows an interior view of the two different types of finish materials used in the office buildings. The left image represents the very common type of office interior finishes used in the concrete, steel and timber buildings. The right image is the internal view of an office in the timber-plus building. Carpet was applied to both types of finishes, but can potentially be replaced by timber floor (Parquet) in the timber-plus 
building. These images graphically represent what, in this thesis, is understood as 'common practice' finishes and the variation of this, using timber in the case of the right hand image.
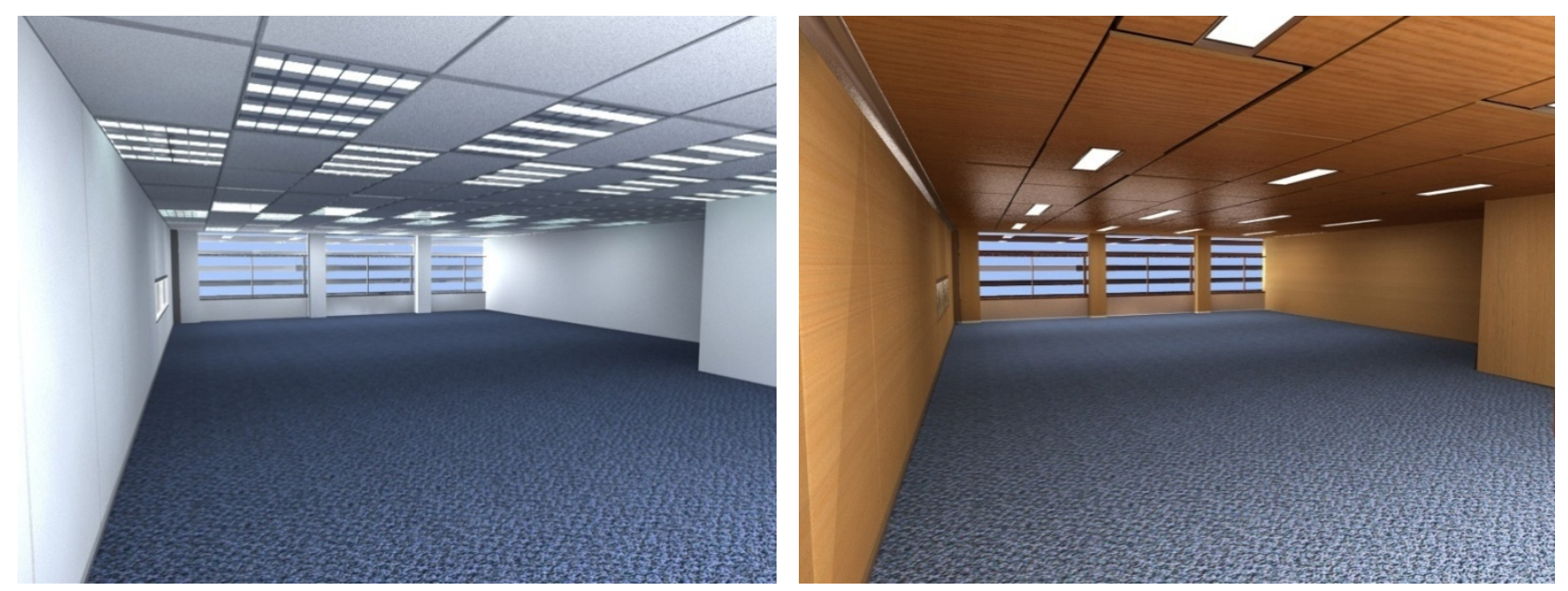

Figure 3-12: 'Common finishes' of the concrete, steel and timber buildings, compared with the internal finishes of the timber-plus building. 


\subsection{Assessment of buildings' operating energy consumption and $\mathrm{CO}_{2}$ emissions:}

This section presents the data setup used in the operating energy simulation process and in the operating $\mathrm{CO}_{2}$ emissions assessment. It mainly describes the thermal envelope configuration of the four buildings, the description of the HVAC system used, the lighting system, the schedule for simulations and the $\mathrm{CO}_{2}$ factors used for energy generation as electricity and LPG. It also introduces secondary data as buildings floor plan to help understand the format used for results analysis.

Figure 3.13 shows the final plan used for the concrete, steel, timber and timber-plus buildings. It also shows a transversal cross section trough the ventilation chimneys. As it can be seen, the floor is subdivided into four zones; three offices and one corridor and services area on the South side.
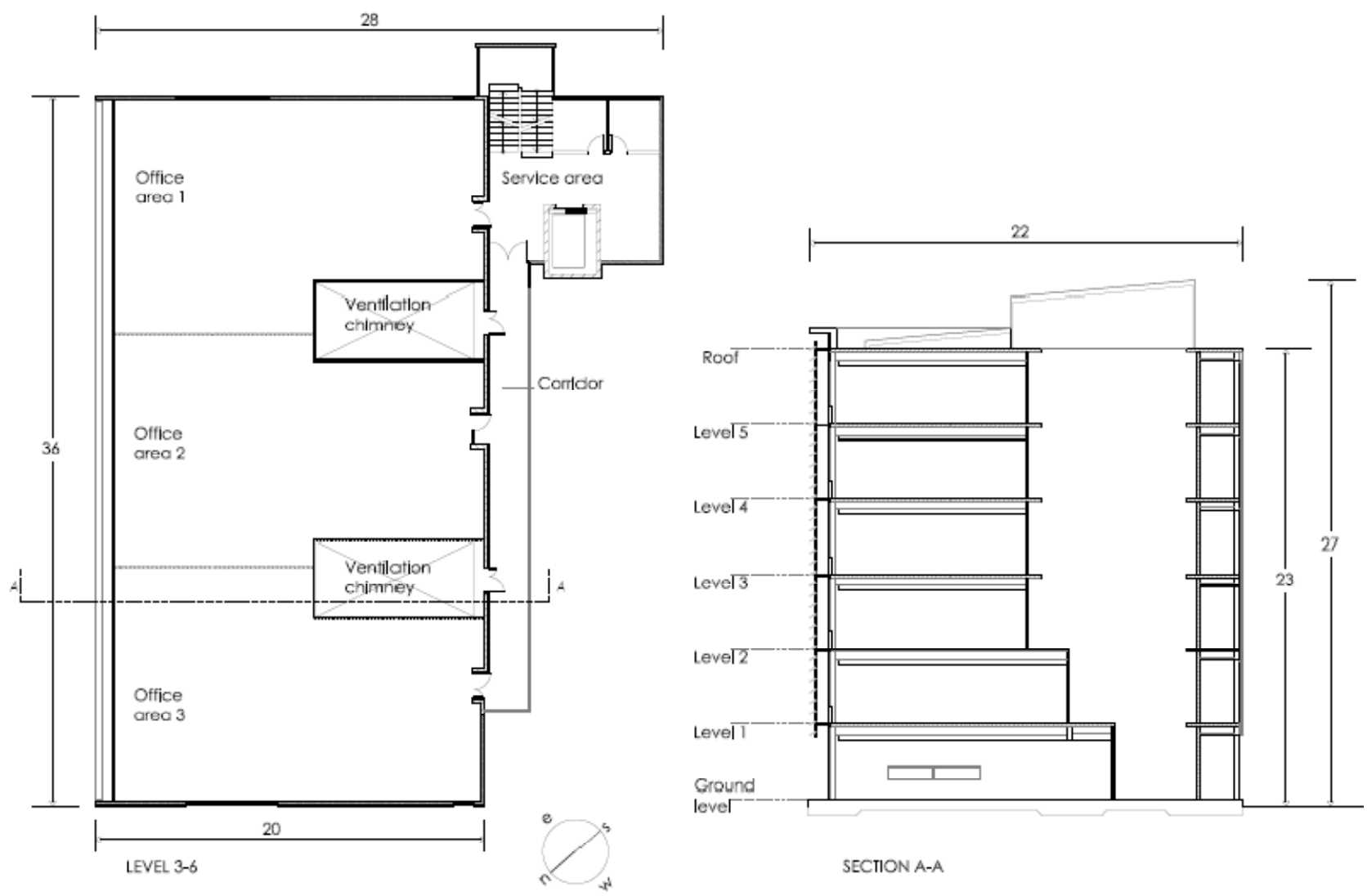

Figure 3-13: Definitive plan used and cross section trough ventilation chimneys

An energy performance simulation was undertaken to assess the operating energy consumption of each building. The four buildings were all designed to have similar operating energy consumptions. This required different designs for the construction of the envelope walls, thermal mass, and heating and cooling equipment in each of the four buildings. With similar operational energy consumptions, differences in the final environmental performance of the four buildings will highlight any differences in the embodied and recurrent energy and $\mathrm{CO}_{2}$ emissions in the materials used in each building. 
The energy simulation was initially undertaken for the concrete building using DesignBuilder software (DesignBuilder Software, 2008). That energy consumption was then used as a benchmark energy target for the steel, timber and timber-plus buildings. Subsequent energy simulations were undertaken with the alternative buildings, aiming to reach the benchmark set by the concrete building. Finally, once the benchmark was reached, simulations were carried out to assess the small differences between the energy performances of each of the four buildings; these are explained in Chapter 4.

For operating energy modelling, only the office zones have HVAC control. The corridors and service areas have windows that open manually, set for natural ventilation. Two large ventilation chimneys (section A-A in Figure 3.13) were included in the initial concrete design for the laboratory building, and these are retained in the four alternative designs used in this project. The ventilation chimneys continue through all floors from ground level up to the plant room on the roof slab. They are used for natural ventilation with louvres that open automatically, set to be opened above $22^{\circ} \mathrm{C}$ up to $26^{\circ} \mathrm{C}$. Chimneys expel the air to the plant room in the roof and from these, through openable louvres, to the exterior. When the louver openings are closed, the air conditioning keeps the temperature at $26^{\circ} \mathrm{C}$ until $6 \mathrm{pm}$ during week days (see Table 3.2 for the schedule used in simulation). 


\subsubsection{Simulation method:}

To understand the simulation process, this section will introduce the input data that goes into the software for simulation, the description of the HVAC system used, the lighting system, thermal envelope configuration of the four buildings and the schedule used for simulations. For the conversion of energy into $\mathrm{CO}_{2}$ emissions this section will introduce the $\mathrm{CO}_{2}$ factors used in New Zealand for electricity and LPG.

The laboratory building was initially designed to have a low energy consumption and to perform better than the minimum requirements of New Zealand Standard NZS 4243 Energy Efficiency - Large Buildings (NZS, 1996). Subsequently, all four buildings in this research had performed similarly in terms of energy consumption (close to $85 \mathrm{kWh} / \mathrm{m}^{2} . \mathrm{yr}$ ). This is particularly important because several previous researchers have found that when the energy efficiency of building is code-compliant, the effects of construction materials and embodied energy are negligible (Cole \& Kernan, 1996; Page, 2006; Sartori \& Hestnes, 2007; Suzuki \& Oka, 1998).

For the simulation carried out in this study, a Wellington based engineering company was involved to supervise the simulation process. The company was eCubed Building service engineering and building science Workshop Ltd whose expertise is in assessing architectural designs. Many of the inputs are default data based on NZS 4243 , but some data is from the DesignBuilder software library database and other sources such as the New Zealand Green Building Council and eCubed Building Workshop Ltd, were also used as inputs (Arnold, personal communication, 15, June, 2007), (NZ Green Building Council, 2007, 2008; Standards Association of New, 1985; Standards New Zealand, 1997).

Table 3.1 summarises the input data used for energy consumption simulation. It contains the value of each input, the units and also identifies the source from which this data was obtained. All inputs in Table 3.1 are common to the concrete, steel, timber and timber-plus buildings.

\begin{tabular}{|c|c|c|c|}
\hline Data & Value & Unit & Source \\
\hline Metabolic Rate & 0.9 & Met & Ashrae comfort tool \\
\hline Occupancy & 0.1 & People/m² & NZS:4243 \\
\hline Plug Load (Office Equipment) & 8 & $\mathrm{~W} / \mathrm{m}^{2}$ & NZS:4243 \\
\hline Heating set point & 22 & Celsius & e Cubed \\
\hline Natural ventilation & 24 & Celsius & e Cubed \\
\hline Cooling set point & 26 & Celsius & e Cubed \\
\hline Min. fresh air & 8 & I/s - person & NZS:1330 \\
\hline Lifts & 4 & $\mathrm{kWh} / \mathrm{m}^{2}$ & NZGBC \\
\hline Infiltration & 0.25 & $\mathrm{ACH}^{*}$ & NZGBC \\
\hline DHW & 4 & $\mathrm{kWh} / \mathrm{m}^{2}$ & NZGBC \\
\hline Office lighting & 400 & Lux & AS/NZS 1680.1:2006 \\
\hline Office lighting power density & 13.6 & $\mathrm{~W} / \mathrm{m}^{2}$ & DesignBuilder \\
\hline Corridos and service areas Lighting & 100 & Lux & AS/NZS 1680.1:2006 \\
\hline
\end{tabular}

Table 3.1: Simulation input values 
Due to the large amount of energy consumed for lighting and office equipment, the simulation input data for lighting in Table 3.1 is particularly important. For lighting, Table 3.1 presents the amount of light (400 Lux in office areas) and the power density $\left(13.6 \mathrm{~W} / \mathrm{m}^{2}\right)$, which in this case is the electricity that the equipment consumed to produce 400 Lux of light. Plug loads are all the energy office equipment uses during office hours, which are set in DesignBuilder as $8 \mathrm{~W} / \mathrm{m}^{2}$ of office area. Only the energy consumption of heating and cooling are expected to vary between buildings. In other words, lighting, DHW, lifts and plug loads have been set as having the same energy consumption in all four buildings in this research. The following section describes the HVAC system used by the buildings in simulation. Metabolic rate, occupancy and infiltration will also be explained because of their direct influence on the HVAC energy consumption.

\subsubsection{HVAC}

The HVAC system used in simulation was chosen from many default possibilities in DesignBuilder. From all default alternatives the system used was hot water radiators for perimeter heating and mixed-mode between natural ventilation and mechanical HVAC. This system was the only alternative in DesignBuilder that mixed natural ventilation and mechanical cooling.

In Table 3.1 in Section 3.4.1 (Simulation methods), the set points for heating, natural ventilation and cooling are presented. The HVAC system operates when the inside temperature is below $22^{\circ} \mathrm{C}$ and above $26^{\circ} \mathrm{C}$. Between $22^{\circ} \mathrm{C}$ and $26^{\circ} \mathrm{C}$ the building works under a natural ventilation mode with no heating or cooling. The building's design includes two internal ventilation chimneys that, under natural ventilation mode, are set in simulation to exhaust the air coming into the buildings through openable windows in the curtain wall of the North façade. Above $26^{\circ} \mathrm{C}$, air conditioning keeps the temperature constant.

\subsubsection{Schedule}

All four buildings were simulated as typical office buildings using schedules for simulation based on NZS 4243. Three schedules were developed to determine the percentage of loads for items such as occupancy, plugs and lighting, and HVAC operation.

12-8am 8-11am 11-6pm 6-10pm 10-12am

1 Occupancy

\begin{tabular}{|r|r|r|r|r|r|}
\hline Week & $0 \%$ & $95 \%$ & $95 \%$ & $5 \%$ & $0 \%$ \\
\hline Saturday & $0 \%$ & $10 \%$ & $5 \%$ & $0 \%$ & $0 \%$ \\
\hline Sunday & $0 \%$ & $5 \%$ & $5 \%$ & $0 \%$ & $0 \%$ \\
\hline
\end{tabular}

2 Plug and Lighting

\begin{tabular}{|r|r|r|r|r|r|}
\hline Week & $5 \%$ & $90 \%$ & $90 \%$ & $30 \%$ & $5 \%$ \\
\hline Saturday & $5 \%$ & $30 \%$ & $15 \%$ & $5 \%$ & $5 \%$ \\
\hline Sunday & $5 \%$ & $5 \%$ & $5 \%$ & $5 \%$ & $5 \%$ \\
\hline
\end{tabular}

3 Operation HVAC Typical NZ office

\begin{tabular}{|r|r|r|r|r|r|}
\hline (Mon - Sat) Week & $0 \%$ & $100 \%$ & $100 \%$ & $0 \%$ & $0 \%$ \\
\hline Sunday & $0 \%$ & $0 \%$ & $0 \%$ & $0 \%$ & $0 \%$ \\
\hline
\end{tabular}

Table 3.2: Schedule for operating energy simulation 
As it can be seen in Table 3.2, the buildings' climate is controlled during week days from 8am until $6 \mathrm{pm}$ and on Saturdays from 8am until 11am, with no occupancy on a Sunday. The HVAC runs from Monday until Saturday at $100 \%$ of the assigned relevant heating or cooling load from $8 \mathrm{am}$ until $6 \mathrm{pm}$, and for the rest of the time, including all of Sunday, is set as $0 \%$ until Monday $8 \mathrm{am}$.

\subsubsection{Buildings thermal envelope description}

The construction and heat losses of each of the walls involved in the envelope of the main body of offices are shown for the concrete, steel, timber and timber-plus buildings in Table B.1 (Appendix B.1). This information is of importance because (as stated in Section 3.4) only the office areas use HVAC (mixed with natural ventilation) so there is significant energy consumption required to keep a comfortable range of temperature inside those areas, with heat losses through walls having a particularly large impact.

Table B.1 (Appendix B.1) shows the construction of the office area envelope walls, including wall thickness, $R$-values and the percentage of the section of each wall configuration type within the total wall, for the concrete, steel, timber and timber-plus buildings. Total walls R-values calculations were calculated by the software used for simulations (DesignBuilder).

In Table B.1, a significant difference between the concrete building (with high thermal mass) and the three other buildings represented (steel, timber and timber-plus) (with lower thermal mass) is that the concrete building has an increased wall thickness in the East and West facades (thermomass) than those of the steel, timber or timber-plus buildings. Despite its much greater thickness, the R-values are lower for the concrete building than for the others. The wall description in all four buildings is segregated into cavity walls and structural walls.

All light weight envelope walls in the steel, timber and timber-plus buildings, including the South façade internal wall of the concrete building, have $90 \mathrm{~mm}$ thick fibreglass insulation. There was no variation in insulation thickness between the buildings, so the final R-value differences between light weight walls is due to the influence of different linings, claddings and air cavity thickness. For example, the timber-plus building normally has higher R-values than the timber building, due to timber external claddings and interior linings. When looking at lightweight walls in any of the four buildings, the cavity is the section of the wall that contains insulation between the internal linings and the external air cavity under the cladding, and the structure is the section of the wall that contains the studs and nogs (blocking); together, cavity and structure act as a thermal bridge. In the case of the steel building, the part of the wall structure acting as a thermal bridge is only the web of the cold-rolled steel channel used as studs. On the other hand, in a timber frame wall, the area acting as a thermal bridge is the complete timber stud width. Nevertheless, thermal conductivity is much higher in steel $(45.3 \mathrm{~W} / \mathrm{mK})$ than in timber $(0.11 \mathrm{~W} / \mathrm{mK})$, so the incidence of the small portion of steel in a steel framed wall is as significant as a much larger portion of wood in a timber framed wall (ASHRAE American Society of Heating, 2005). 
Because of the high thermal conductivity of steel, the main structural system of the steel building was left inside the offices and not within envelope walls, so it will not drastically increase the heat losses. On the other hand, in the concrete, timber and timber-plus buildings, as explained in Section 3.3, the structural systems are rather similar and the shear walls are part of the structural system. This means that in the East and West façades, the structural walls are part of the envelope walls, somewhat decreasing the total Rvalue. In the concrete building there is a layer of extruded polyurethane in the core of the structural walls but in the timber and timber-plus buildings no extra insulation has been added to the shear walls. The influence of structural components on the thermal envelope is the main reason why all four buildings cannot have the same R-value even when the same insulation is used.

Due to the amount of concrete in the concrete building, this is expected to behave as a high mass building, storing and exchanging heat, and keeping the temperature more constant than in any of the remaining three buildings in this research. The effect of thermal mass can not be appreciated when looking at $R$-values of the concrete building against the steel, timber or timber-plus buildings. The three latter are lightweight buildings, but all contain concrete topping in the floor. In the case of the steel building, the concrete floors are $150 \mathrm{~mm}$ thick and in the case of the timber and timber-plus the concrete topping is only $60 \mathrm{~mm}$. Due to significant differences in the amount of concrete in the floors of the concrete, steel, timber and timber-plus buildings, simulations were undertaken using a carpet covering the floor of all buildings. Carpet is expected to lower the influence of concrete as a thermal mass and will moderate the influence of a thermal mass on the heating and cooling energy consumption.

As was previously explained, the concrete building has a continuous layer of extruded polyurethane in its entire envelope and the steel building has all envelope walls running outside the structure. Only the timber structure has the structural shear walls acting as thermal bridges within the envelope walls. Finally, between the timber and timber-plus buildings, the latter has solid wood partitions and linings exposed to the offices' interior. Solid wood acts as a thermal mass. Due to this, the final heating and cooling energy consumption of the timber-plus building should be lower than in the timber building (Bellamy \& Mackenzie, 2007). 


\subsubsection{Floor areas for simulation}

In the analysis of the results this research used the Net Usable Area. The ventilation system occupies a large area of space within the building; the large vertical void areas used as chimneys connected to a plant room on the roof, were taken out of the gross floor area for the calculation of the Net Usable Area. Table 3.3 shows the initial gross floor area (calculated inside the envelope walls) and then segregates it into the floor area allocated in the ventilation chimneys and plant room, offices and corridors' floor area. Finally, Table 3.3 shows the Net Usable Area that was calculated adding the office floor area to the corridors' floor area.

\begin{tabular}{|c|c|}
\hline Gross floor area & $4,247 \mathrm{~m}^{2}$ \\
\hline Chimneys and plant room & $711 \mathrm{~m}^{2}$ \\
\hline Offices & $2,745 \mathrm{~m}^{2}$ \\
\hline Corridors & $792 \mathrm{~m}^{2}$ \\
\hline Net Usable Area (Offices + Corridors): & $3,536 \mathrm{~m}^{2}$ \\
\hline
\end{tabular}

Table 3.3: Calculation of the Net Usable Area for the analysis of results

Initially, the Net Usable Area was used for the calculation of the operating energy consumption intensity per square metre. This allows for the calculation of the intensity per square metre, of operating energy consumption and $\mathrm{CO}_{2}$ emissions. Subsequently, in order to have a single result for life-cycle energy consumption and $\mathrm{CO}_{2}$ emissions per square metre, the initial and recurrent embodied energy and initial and recurrent embodied $\mathrm{CO}_{2}$ emissions were subdivided also by Net Usable Area. All results regarding the intensity of either energy or $\mathrm{CO}_{2}$ emissions per square metre are presented as Net Usable Area.

\subsubsection{Energy sources and $\mathrm{CO}_{2}$ factors}

To determine the $\mathrm{CO}_{2}$ emissions of the energy sources used in this thesis, it was necessary to identify a reliable source of data specific to New Zealand. The New Zealand business council for sustainable development (NZBCSD) provides an "Emissions calculator" which provides $\mathrm{CO}_{2}$ factors for several different activities in New Zealand, including energy sources as Petrol, Diesel, LPG, Gas, Coal and Electricity production (New Zealand Business Council for Sustainable Development, 2008). It is necessary to clarify that the $\mathrm{CO}_{2}$ factors of electricity and LPG finally used in this thesis account only for $\mathrm{CO}_{2}$ and no other green house gases are accounted. In other words, factors of $\mathrm{CO}_{2}$ used for electricity and LPG are $\mathrm{CO}_{2}$ and not $\mathrm{CO}_{2}$ equivalent values.

The emissions calculator produced by NZBCSD uses international emissions factors that have been peer reviewed and represent a solid basis to calculate most of the emissions inventory. However, some energy production is different between countries. For some of the above mentioned processes, New Zealand has unique characteristics, such as a high proportion of electricity generation using renewable hydro resources. The NZBCSD have consequently integrated some New Zealand specific emission factors, particularly for electricity production. The factor suggested by NZBCSD has been additionally refined by organisations such as the New Zealand Energy Efficiency and Conservation Authority (EECA) and Landcare Research, yet this 
factor "has no official status and official electricity emissions factors are still under development for Government policy mechanisms such as projects and NGAs" (New Zealand Business Council for Sustainable Development, 2008).

In this thesis natural gas is the fuel used for the heating system and domestic hot water, and electricity is used for cooling, lighting and office equipment energy. Once the outcomes of the simulations were produced, results showed the annual fuel consumption broken into natural gas and electricity. The coefficients of $\mathrm{CO}_{2}$ emissions are different for electricity and natural gas. The coefficient suggested by NZBCSD for new buildings is 0.000450 tonnes of $\mathrm{CO}_{2}$ emitted for a GJ of electricity. "This electricity emissions factor estimates the emissions intensity of the expected mix of new generation over the next five years. This number represents a grid factor and does not reflect physical (or contractual) supply in all cases" (New Zealand Business Council for Sustainable Development, 2008).

When looking at the gas coefficient, since there is no reticulated gas in Christchurch and the use of LPG (shipped in) is the fuel substitution of Natural Gas, the coefficient of LPG is suggested as 0.0604 tonnes of $\mathrm{CO}_{2}$ emitted by $\mathrm{GJ}$ of energy produced. This is an important factor in calculation because having the same total energy use in the different buildings might imply that different proportions of gas and electricity were used. Subsequently having the same total energy use in the operation may not imply having the same $\mathrm{CO}_{2}$ emissions since LPG has a much higher $\mathrm{CO}_{2}$ coefficient than electricity. 


\subsection{Assessment of buildings' embodied energy and embodied $\mathrm{CO}_{2}$ emissions}

This section introduces the scope of the assessment undertaken for the materials used in each of the buildings. Following that is an introduction on the methodology used for the quantity of materials calculation and the schedule for materials replacement of the concrete, steel, timber and timber-plus buildings. Quantities of materials are necessary to calculate the initial embodied energy and initial embodied $\mathrm{CO}_{2}$ emissions in the materials used to initially build the buildings. The schedule of materials replacement is necessary to calculate the embodied energy and embodied $\mathrm{CO}_{2}$ of the material added to the buildings through maintenance; this is recognised in this thesis as recurrent embodied energy and recurrent embodied $\mathrm{CO}_{2}$ emissions. Finally this section will introduce the data of embodied energy and embodied $\mathrm{CO}_{2}$ coefficients used in this thesis.

\subsubsection{LCA scope in this research}

Buildings go through many stages throughout their useful life, none of which are particularly simple to analyse from an environmental point of view. From their initial conception to final recycling, re-use or demolition, a whole range of processes must be taken into account. These include "transportation to site, site erection and construction, life time use of building or structure, repairs, maintenance and refurbishment, demolition or dismantling at end of life, transportation for reuse, and recycling or disposal" (Cole \& Kernan, 1996; Eaton \& Amato, 1998). In short, a full LCA is required if one is to properly and thoroughly assess the environmental impact of a building.

An LCA is an analytical methodology which provides a suitable tool for assessing the environmental performance of a building by taking a systematic perspective over its whole life-cycle, from cradle to grave (Nebel, 2007; Zsuzsa \& Nebel, 2006). The explanation of the LCA methodology is established on the International standards of series ISO 14040. According to Ortiz et al. (2007) LCA consists of four distinct analytical steps: a definition of the goal and scope, producing the Life Cycle Inventory ( $\mathrm{LCl})$, assessing the impact and interpreting the results.

Normally an LCA involves various environmental assessments such as emissions, wastes and resources used. In this study, the scope of the assessment is reduced to energy use and $\mathrm{CO}_{2}$ emissions. For the life stages of a building, between initial conception and final recycling or disposal, the scope of this assessment is reduced to the following three main stages in the life (and potential environmental impact) of a building:

- Initial production of the building materials.

- Operation of the building.

- Maintenance of the building materials over the building's effective life.

Other stages such as construction of the building, demolition and disposal are much more difficult to assess and in the case of demolition and disposal these are difficult to predict so many years in advance. By the other hand regarding the four analytical steps that Ortiz et al. (2007) suggest, particular emphasis will be 
placed on the influence of the $\mathrm{LCl}$ used in the assessment of the impact and in the final interpretation of the results.

\subsubsection{Measurement of quantities}

In order to calculate the energy in the initial production of all materials involved in the buildings, the drawings of the structure and architecture of the four buildings were submitted to a quantity surveyor (Davis Langdon) for measurement of material quantities, along with cost estimates. They were asked to measure the quantities of eleven construction materials: concrete, reinforcing steel, structural steel, other steel, glass, timber, aluminium, plasterboard, paint, particleboard/fibreboard and insulation. Subsequently each of these main materials was subdivided into specific items (e.g. timber was subdivided into plywood, LVL, sawn timber, MDF and imported cedar). Table 3.4 shows the outline of the schedule of materials produced by the quantity surveyor for the concrete building.

Building component Buildings Sub-component

\begin{tabular}{|c|c|c|c|}
\hline 1 & Foundations: & \begin{tabular}{|l} 
Beam Foundations \\
Raft Foundations
\end{tabular} & $\begin{array}{l}\text { - Concrete, reinforcing Steel } \\
\text { - Concrete, reinforcing Steel }\end{array}$ \\
\hline & Ground Floor Slabs: & & - Concrete, reinforcing Steel \\
\hline 3 & Suspended floors: & & - Concrete, reinforcing Steel \\
\hline 4 & Structure: & \begin{tabular}{|l|} 
Portals \\
Columns \\
Beams \\
Walls
\end{tabular} & $\begin{array}{l}\text { - Structural Steel } \\
\text { - Concrete, reinforcing Steel } \\
\text { - Concrete, reinforcing Steel } \\
\text { - Concrete, reinforcing Steel }\end{array}$ \\
\hline 5 & Stairs: & \begin{tabular}{|l} 
Stairs \\
Balustrading
\end{tabular} & $\begin{array}{l}\text { - Concrete, reinforcing Steel } \\
\text { - Glass }\end{array}$ \\
\hline 6 & Roof: & $\begin{array}{l}\text { Plant Room } \\
\text { Roof } \\
\text { Spouting \& downpipes }\end{array}$ & $\begin{array}{l}\text { - Other Steel, timber } \\
\text { - Other Steel, timber } \\
\text { - Other Steel }\end{array}$ \\
\hline 7 & Exterior walls: & $\begin{array}{l}\text { Exterior Wall Framing } \\
\text { Soffit Framing } \\
\text { Exotec fibrecement walls \& soffits } \\
\text { Walls - R2.6 } \\
\text { Walls - } 13 \text { Standard } \\
\text { Polystyrene }\end{array}$ & $\begin{array}{l}\text { - Timber } \\
\text { - Timber } \\
\text { - Particleboard/fibreboard, paint } \\
\text { - Insulation } \\
\text { - Plasterboard } \\
\text { - Insulation }\end{array}$ \\
\hline 8 & Windows: & $\begin{array}{l}\text { Windows } \\
\text { Window reveals }\end{array}$ & $\begin{array}{l}\text { - Glass, aluminium } \\
\text { - Timber }\end{array}$ \\
\hline 9 & Doors: & & - Glass, timber, paint, aluminium \\
\hline 10 & Interior wall: & $\begin{array}{l}\text { Interior Wall Framing } \\
\text { Walls - } 13 \text { Standard } \\
\text { Walls - } 13 \text { Fyreline } \\
\text { Walls - acoustic } \\
\end{array}$ & $\begin{array}{l}\text { - Timber } \\
\text { - Plasterboard, paint } \\
\text { - Plasterboard, paint } \\
\text { - Insulation } \\
\end{array}$ \\
\hline 11 & Ceiling offices: & \begin{tabular}{|l} 
Ceilings \\
Mineral fibre ceiling tiles
\end{tabular} & $\begin{array}{l}\text { - Insulation } \\
\text { - Particleboard/fibreboard }\end{array}$ \\
\hline 12 & Louvers: & Louvres & - Aluminium \\
\hline
\end{tabular}

Table 3.4: Concrete building schedule from Quantity Surveyor

In Table 3.4 the schedule of materials of the concrete building is organised into three columns. The first column on the left includes 12 building components which are then subdivided into 29 sub-components. Subcomponents range from one to six per building component. Finally, each sub-component has one to four different materials. 
The 12 building components and 29 sub-components are the same for the concrete, steel, timber and timber-plus buildings. Only the materials used in each sub-component vary between buildings. Table B.2 (Appendix B.2) shows for each of the eleven materials in the Quantitative Surveyor Schedule, the alternative chosen for the concrete building from the list of materials in Alcorn (2003), embodied energy and the embodied $\mathrm{CO}_{2}$ coefficients of buildings materials.

For most of the materials in the schedule produced by the quantity surveyor, a total weight in tonnes was assigned (except in the case of paint where only the area was assigned). Once the schedule of quantities of materials was produced, the calculation of the initial embodied energy, in other words the embodied energy and $\mathrm{CO}_{2}$ of the materials included in the construction of the building (at the beginning of year 1 of its lifecycle) is a straight forward process when Alcorn (2003) coefficients are used. The embodied energy and embodied $\mathrm{CO}_{2}$ emissions calculation sheet of each building is presented in the attached $\mathrm{CD}$ where the multiplication of the tonnes of buildings materials by the coefficients of embodied energy and embodied $\mathrm{CO}_{2}$ published in Alcorn (2003) and (Alcorn, personal communication, March 13, 2008), can be seen.

\subsubsection{Recurrent embodied energy}

A schedule of material life spans, and resulting maintenance energy developed by SCION research (Love, personal communication, April 8, 2008) was used to estimate recurrent energy and $\mathrm{CO}_{2}$ emissions of the buildings (involves the embodied energy and $\mathrm{CO}_{2}$ emissions of all the materials used in the maintenance and refurbishment of buildings during its 60 year life-cycle). Table B.3 (Appendix B.3) shows the schedule of buildings materials life spans organised into the three sources that were used to obtain that information. Having this data available, the schedules of maintenance were produced for the concrete, steel, timber and timber-plus buildings. Subsequently, the calculation of embodied energy and embodied $\mathrm{CO}_{2}$ emissions of the materials incorporated by maintenance was calculated; this is recognised in this research as the recurrent embodied energy and recurrent embodied $\mathrm{CO}_{2}$.

It is important to mention that structural components and insulation are expected to last the entire lifespan of the building, which is 60 years. It is assumed that any replacements needed will be with an identical material to the original. As it was explained before, the functional unit in the building life-cycle is 60 years, this means for example that when a material needs to be replaced at 8 years, the number of replacements will be 6.5 or if it needs to be replaced at 50 years, the number of replacements will be 0.2 . Figures in Table B. 3 are all relevant to the buildings. Where the exact material is not given, the closest approximation is used. In some cases more than one value is given for a single material, in which case the 'Life Cycle Assessment of a New Zealand house' figure is used, as it is calculated from many studies. 


\subsection{Embodied energy and embodied $\mathrm{CO}_{2}$ data used}

As explained in Section 3.4.1 (LCA scope in this research), the production of the LCl is fundamental to undertake a LCA and this involves collecting data for each material (unit process) regarding all relevant inputs and outputs of energy and mass flow, as well as data on emissions to air, water and land. Today there are some LCl databases available from industrialised countries for LCA, these are: CML, DEAM TM, Ecoinvent Data, GaBi 4 professional, IO-database for Denmark 1999, SimaPro database, the Boustead Model 5.0 and US Life-cycle inventory database (Ortiz, Castells, \& Sonnemann, 2007).

Particularly in the case of New Zealand, the Centre for Building Performance Research at Victoria University of Wellington (Alcorn 2003) undertook the most significant and comprehensive LCl-related work on building production in New Zealand. This database compiled the embodied energy and $\mathrm{CO}_{2}$ emissions of approximately 60 building products using a mixture of industry, input-output, and statistical data (Nebel, 2007).

With produced LCI or LCl-related databases available, various LCA tools have been developed and are available for use in environmental assessment for items such as buildings or buildings components. These tools are: GaBi (Germany), SimaPro (Nederlands), TEAM (France) and LCAiT (Sweden) (Ortiz et al., 2007). Of particular importance to this research is the GaBi software tool for LCA studies; this tool was developed at the University of Stuttgart and the consultancy PE Europe $\mathrm{GmbH}$. Part of the software is a database for buildings materials, based on average German industry data collected by PE Europe between 1996 and 2004.

This initial plan of this research was to produce a 'compacted' LCA assessing only the three main life stages mentioned before in the concrete, steel, timber and timber-plus building, applying the New Zealand-specific data (Alcorn 2003). A parallel research emerged after the four buildings were produced and the operating energy assessment was done. This parallel research was carried out by Scion Research and was requested by the New Zealand Ministry of Agriculture and Forestry (MAF). The MAF research produced a complete LCA of the concrete, steel, timber and timber-plus buildings produced by the author of this thesis using the same operating energy assessment. To produce the LCA, the tool used by Scion Research was the GaBi 4.2 professional LCA tool.

Using the schedule of materials produced by the quantity surveyor, both the author of this thesis and Scion Research calculated the initial and recurrent embodied energy and the initial and recurrent embodied $\mathrm{CO}_{2}$ emissions of the four buildings by using Alcorn (2003) in the case of the author of this thesis and $\mathrm{GaBi}$ professional LCA tool in the case of Scion Research. Finally Scion Research provided the author of this thesis with the results of those assessments produced using the GaBi professional LCA tool. Due to this, the results chapter will present the data of initial and recurrent energy and initial and recurrent $\mathrm{CO}_{2}$ segregated between the Alcorn and the GaBi result. These parallel sets of results provide an opportunity to evaluate the influence of the LCl database used into the final LCA outcome. It is also important is to assess the difference in results produced by New Zealand-specific data and overseas data. 


\subsubsection{Overview of the differences between the Alcorn and the GaBi data}

There are two researches that compare the data in Alcorn (2003) against other overseas data. The most significant is by Szalay and Nebel (2006), which is a direct comparison of the Alcorn (2003) data with various overseas data including the GaBi and Nebel (2007) which analysed one case study using Alcorn (2003), $\mathrm{GaBi}$ and Ecoinvent data. Those two reports found that New Zealand data is in a range between 20 and $350 \%$ of the overseas data with no general trend of New Zealand data being lower or higher than overseas data.

Table B.4 (Appendixes B.3) shows a table produced by Szalay and Nebel (2006) with the comparison of the Alcorn and the $\mathrm{GaBi}$ data on embodied energy and embodied $\mathrm{CO}_{2}$ emissions of 27 buildings materials. As it can be seen some buildings materials, such as aluminium and timber in the New Zealand data are lower, but for others such as cement, gypsum board or steel, the results are higher (Szalay \& Nebel, 2006).

\subsubsection{Country/region related differences}

Country-specific differences are mainly due to different fuel types and electricity production mixes, and the transport distances. In New Zealand $62 \%$ of electricity is generated by hydro power while the German electricity mix (used in $\mathrm{GaBi}$ ) is dominated by nuclear power, lignite and hard coal with hydro power accounting for only $4 \%$ (Szalay \& Nebel, 2006).

An example of the influence of different energy mixes on the data created is in the production of aluminium. The process of electrolysis required to produce aluminium involves high amounts of electricity. The energy and emissions related to a high use of hydro power, for electricity production, are generally less than if fossil fuels are dominant in the mix.

Transport distances are also different in the two databases. Particularly in New Zealand, a number of raw materials have to be shipped to New Zealand from overseas. Subsequently the transport-related emissions and energy requirements results are higher for New Zealand than for Germany (Szalay \& Nebel, 2006).

\subsubsection{Differences in inventory analysis}

Alcorn has sourced data using information obtained from individual manufacturers; the method used is recognised as hybrid analysis, which is a combination of process analysis and economical I/O analysis. When the acquisition of further data provided by industrial organisations and individual companies is condensed, additional I/O coefficients, based on economic values, were used (Alcorn, 2008; Szalay \& Nebel, 2006).

The GaBi data is from a far more sophisticated analysis mostly based on a detailed process analysis. The inputs to manufacture of each material, including sourcing raw materials for all the constituent components of each material, are assessed. The inventory data is average industry data for a given region or country. 
Many system boundaries of data are often different between the two databases. For Polyvinyl chloride (PVC), for example, Alcorn includes the process of extrusion, while the GaBi data ends at the granulate stage. Another significant difference is in the ratio of recycling scrap and virgin steel mix in metal production. For copper values for example, the Alcorn data relates to virgin copper, while in $\mathrm{GaBi}$ a ratio of $40 \%$ recycling scrap and 60\% virgin is used respectively (Szalay \& Nebel, 2006).

\subsubsection{Impact assessment categories}

There is different scope between the environmental impacts assessed by Alcorn and GaBi. Alcorn assesses the embodied energy and embodied $\mathrm{CO}_{2}$ emissions. $\mathrm{GaBi}$, on the other hand, utilises a more complete inventory of environmental impacts, such as embodied energy, global warming, acidification, eutrophication, ozone depletion, photo-oxidant formation, as well as human toxicity and ecotoxicity (Zsuzsa \& Nebel, 2006). This research is limited to embodied energy and embodied $\mathrm{CO}_{2}$. In $\mathrm{GaBi}$ the embodied energy is split into renewable (hydro, solar, geothermal, biomass) and non-renewable (fossil, nuclear) resources, while in Alcorn only the total energy figures are presented. On the other hand, the Alcorn $\mathrm{CO}_{2}$ data is obtained directly from the fossil fuel component of the embodied energy, adding chemical emissions where necessary (cement production). The $\mathrm{GaBi} \mathrm{CO}_{2}$ data considers all greenhouse gases, including methane, $\mathrm{CFCs}$ and $\mathrm{HCFCs}$, with the results converted into tonnes of $\mathrm{CO}_{2}$ equivalent emissions.

\subsubsection{Negative $\mathrm{CO}_{2}$ coefficients for timber in Alcorn and not in $\mathrm{GaBi}$ :}

Trees remove $\mathrm{CO}_{2}$ from the atmosphere. In other words, trees sequester carbon from the atmosphere; this is expressed as $\mathrm{CO}_{2}$ emissions which have not occurred because the carbon is 'locked up' in the tree and subsequently in timber materials. Negative embodied $\mathrm{CO}_{2}$ emissions in timber materials mean that the emissions corresponding to the raw material extraction and the manufacturing do not exceed the amount of $\mathrm{CO}_{2}$ removed from the atmosphere.

This approach is valid as long as the analysis goes 'from cradle to gate'. This is because the end of the life assumption will determine whether the $\mathrm{CO}_{2}$ remains locked in the timber material or is released into the atmosphere. The carbon sequestration is extended if the wood is reused or sent to landfill, on the other hand, with the combustion of wood, carbon is released back into the atmosphere (Micales \& Skog, 1997; Szalay \& Nebel, 2006).

Alcorn provides negative $\mathrm{CO}_{2}$ for timber products while $\mathrm{CO}_{2}$ sequestration is not taken into account in $\mathrm{GaBi}$. This is because it is common practice in New Zealand to send demolition timber to landfill, while the GaBi assumption is that all timber will be used as biomass and burned for energy production. Nevertheless, GaBi includes the biomass combustion energy input into the timber materials' embodied energy values, while Alcorn assumes that $100 \%$ of the carbon will be retained in wood materials; research suggests that $0-3 \%$ of the carbon from wood will be released as landfill gas (Micales \& Skog, 1997). 


\subsection{Summary of methodology}

In order to determine the influence of construction materials on the life cycle energy use and $\mathrm{CO}_{2}$ emissions of medium sized commercial buildings a comparison between four buildings was undertaken in this research. All the relevant data for the achievement of the objective stated was introduce in Chapter 3. The design of the four case study and the subsequent assessment of the life cycle energy consumption and $\mathrm{CO}_{2}$ emissions of each of the four buildings was also described. Finally the two different databases with the embodied energy and embodied $\mathrm{CO}_{2}$ emissions of buildings materials were introduced, and compared.

Table 3.5 below shows the calculation scheme for operating and embodied energy and $\mathrm{CO}_{2}$ emissions, as used in this thesis.

\begin{tabular}{|c|c|c|c|c|c|}
\hline \multicolumn{3}{|c|}{ Energy (GJ) } & \multicolumn{3}{|c|}{$\mathrm{CO}_{2}$ emissions $\left(\mathrm{t} \mathrm{CO}_{2}\right)$} \\
\hline Annual operational energy & \multicolumn{2}{|c|}{ a } & Annual operating $\mathrm{CO}_{2}$ emissions & \multicolumn{2}{|l|}{$\mathrm{a}$} \\
\hline Life-cycle operational energy & \multicolumn{2}{|c|}{$b=60 . a$} & Life-cycle operational $\mathrm{CO}_{2}$ emissions & \multicolumn{2}{|c|}{$b=60 . a$} \\
\hline & Alcorn & GaBi & & Alcorn & GaBi \\
\hline Initial embodied energy & C & d & Initial embodied $\mathrm{CO}_{2}$ emissions & C & d \\
\hline Recurrient embodied energy & e & $f$ & Recurrent embodied $\mathrm{CO}_{2}$ emissions & e & $f$ \\
\hline Total embodied energy & $g=c+e$ & $h=d+f$ & Total embodied $\mathrm{CO}_{2}$ emissions & $g=c+e$ & $h=d+f$ \\
\hline Life-cycle energy consumption & $i=b+g$ & $j=b+h$ & Life-cycle $\mathrm{CO}_{2}$ emissions & $i=b+g$ & $j=b+h$ \\
\hline
\end{tabular}

Table 3.5: Calculation scheme for operating and embodied energy and $\mathrm{CO}_{2}$ emissions, as used in this thesis.

This table is designed to clarify the calculation process need for the concrete, steel, timber and timber-plus buildings. It is separated into energy and $\mathrm{CO}_{2}$ emissions, and for calculations of embodied energy and embodied $\mathrm{CO}_{2}$ emissions, the results are separated into the results produced using the Alcorn and the $\mathrm{GaBi}$ database. Finally when the data required in Table 3.5 is completed for each building, the comparison and analysis of the data will drive the approach to the objectives in this thesis.

The calculation of the life cycle energy use and $\mathrm{CO}_{2}$ emissions undertaken in this thesis is a variation of the Life Cycle Assessment method suggested in the ISO standard 14040. First as can be seen in table 3.5 that not all the components of the life cycle energy use and $\mathrm{CO}_{2}$ emissions are included in the scheme of environmental impacts used in this thesis. The energy use and the $\mathrm{CO}_{2}$ emitted in the construction of the buildings and finally the demolition of them is not accounted, neither is the impact of transportation of the materials to the building site. It also necessary to clarify that the accounting of operating energy in this thesis is as delivered energy (i.e. electricity and reticulated gas). Conversely, embodied energy estimates are based on embodied energy coefficients from Alcorn and Gabi which are based in primary energy sources. Finally the ISO standard 14040 specify that many other environmental impacts (i.e. Ozone depletion, water acidification) needs to be added to the energy and green house gases assessment. 
Methodology 


\section{RESULTS}

This chapter presents the results produced in this thesis, clearly separated into energy and $\mathrm{CO}_{2}$ sections. Both life-cycle energy consumption and $\mathrm{CO}_{2}$ emissions introduce the operations first and the embodied energy or $\mathrm{CO}_{2}$ second.

As explained in Section 3.4 (Assessment of Building's embodied energy and embodied $\mathrm{CO}_{2}$ emissions), the four buildings were all designed to have similar operating energy consumption. With similar operational energy consumption, the differences in the final environmental performance of the four buildings will highlight any differences in the embodied and recurrent energy and $\mathrm{CO}_{2}$ emissions in the materials used in each building.

The energy simulation was initially undertaken for the concrete building. That measurement of energy consumption was then used as a benchmark energy target for the steel, timber and timber-plus buildings. Subsequent energy simulations were undertaken with the alternative buildings, aiming to reach the benchmark set by the concrete building. Finally, once the benchmark was reached, simulations were carried out to assess the small differences between the energy performances of each of the four buildings; these are explained in this chapter.

Buildings' architectural drawings were finished after the operating energy benchmark was reached. All drawings were produced after all the buildings were tested in the energy simulation software to be configured to achieve similar operating energy consumption. Structure, on the other hand was produced in parallel by the University of Canterbury for the concrete, timber and timber-plus buildings and by Steel Construction New Zealand for the steel building. The drawings for the structure and architecture of the three buildings were submitted to a quantity surveyor (Davis Langdon) for measurement of material quantities, along with cost estimates. A schedule of material life spans and resulting maintenance energy developed by SCION research was used to estimate recurrent energy and $\mathrm{CO}_{2}$ emissions of the buildings (this involved the embodied energy and $\mathrm{CO}_{2}$ emissions of all the materials used in the maintenance and refurbishment of each building during its 60 year life-cycle).

In Section 34.1 (LCA scope in this research) the scope of the LCA undertaken in this research was described. Using the schedule of materials produced by the quantity surveyor, both the author of this thesis and Scion Research calculated the initial and recurrent embodied energy and the initial and recurrent embodied $\mathrm{CO}_{2}$ emissions of the four buildings by using Alcorn (2003) (in the case of the author of this thesis) and the GaBi professional LCA tool (in the case of Scion Research). Finally Scion Research provided the author of this thesis with the results of those assessments produced by using the GaBi professional LCA tool. From this, this chapter will present the data of initial and recurrent energy and initial and recurrent $\mathrm{CO}_{2}$, segregated between the Alcorn and the GaBi results.

Chapter 4 is divided into two main sections: 4.1 , Life-cycle energy consumption and 4.2 , Life-cycle $\mathrm{CO}_{2}$ emissions. 
Section 4.1 is subdivided into three sub-sections: 4.1.1, 4.1.2 and 4.1.3. Sub-section 4.1.1 is about operating energy and involves the analysis of the results of operating energy consumption from the software simulation, operating energy segregated in end-uses, and the 60 year life-cycle operating energy consumption of a building. Sub-section 4.1.2 is about embodied energy involving the four buildings total embodied energy and the buildings components' total embodied energy. Sub-section 4.1.3 is about the four buildings' total life-cycle energy consumption, including operating and total embodied energy.

Section 4.2 (Life-cycle $\mathrm{CO}_{2}$ emissions) is subdivided in three sub-sections: 4.2.1, 4.2.2, 4.2.3. Sub-section 4.2.1 is about operating $\mathrm{CO}_{2}$ emissions, where the operating $\mathrm{CO}_{2}$ emissions are segregated into end-uses and the 60 year life-cycle operating $\mathrm{CO}_{2}$ emissions. Sub-section 4.2.2 is about embodied $\mathrm{CO}_{2}$ emissions. This involves the four buildings' total embodied $\mathrm{CO}_{2}$ emissions and the buildings components' total embodied $\mathrm{CO}_{2}$ emissions. Sub-section 4.2 .3 is about the four buildings' total life-cycle $\mathrm{CO}_{2}$ emissions, including operating and total embodied $\mathrm{CO}_{2}$ emissions.

\subsection{Life-cycle energy consumption}

Life-cycle energy consumption is calculated by adding operating energy consumption and total embodied energy. Total embodied energy was calculated by adding the initial embodied energy and the recurrent embodied energy; the energy for the buildings' on-site construction is not included in embodied energy. Other life stages of the building not included in this calculation are the transportation of materials from the manufacturing site to the construction site and, the demolition and building's disposal energy at the end of its life-cycle. Nevertheless previous research studies agree that energy consumption in the demolition and disposal work contributes a relatively small amount to the life-cycle energy consumption (Cole \& Kernan, 1996; Suzuki \& Oka, 1998).

\subsubsection{Operating energy}

This section describes the outcomes produced by the energy consumption simulations, and studies the influence of those operational energy consumption differences on the life-cycle energy consumption. Table 4.1 shows the total annual energy consumption in the operations of the concrete, steel, timber and timberplus buildings. The data is disaggregated into electricity and gas, and the total final consumption is divided by the gross floor area (measured inside external walls). As can be seen, the total annual energy consumed in the operation of the four buildings is fairly similar. The biggest difference is between the concrete and the timber building and accounts for a total of $52 \mathrm{GJ}$, representing a 5\% difference.

When operating energy consumed is divided by the building's gross floor area, the concrete building uses 84 $\mathrm{kWh} / \mathrm{m}^{2}$.yr followed by the steel and the timber-plus buildings, both using $86 \mathrm{kWh} / \mathrm{m}^{2} . \mathrm{yr}$, and the timber building, using $88 \mathrm{kWh} / \mathrm{m}^{2}$.yr. The difference between the concrete building (lowest operating energy consumption) and the timber building (largest operating energy consumption) is about $4 \mathrm{kWh} / \mathrm{m}^{2} . \mathrm{yr}$. 
Total annual energy use in operation

kWh

GJ

Difference against

lowest consumption

$\%$ GJ

1 Concrete building

\begin{tabular}{|l|c||c|}
\hline Total electricity & $241,171 \mathrm{kWh}$ & $868 \mathrm{GJ}$ \\
\hline Total Gas & $55,764 \mathrm{kWh}$ & $201 \mathrm{GJ}$ \\
\hline Total energy use: & $\mathbf{2 9 6 , 9 3 5} \mathbf{~ k W h}$ & $\mathbf{1 , 0 6 9} \mathbf{~ G J}$ \\
\hline Total energy use $/ \mathrm{m}^{2}$ : & $\mathbf{8 4} \mathrm{kWh} / \mathrm{m}^{2}$ \\
$\mathbf{n n}$ & $\mathbf{0 . 3 0} \mathbf{~ G J} / \mathrm{m}^{2}$ \\
\hline
\end{tabular}

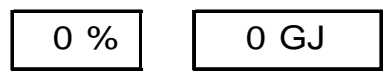

2 Steel building

\begin{tabular}{|c|c|c|}
\hline Total electricity & $245,999 \mathrm{kWh}$ & $886 \mathrm{GJ}$ \\
\hline Total Gas & $56,365 \mathrm{kWh}$ & $203 \mathrm{GJ}$ \\
\hline Total energy use: & 302,363 kWh & 1,089 GJ \\
\hline Total energy use/m ${ }^{2}$ : & $86 \mathrm{kWh} / \mathrm{m}^{2}$ & $0.31 \mathrm{GJ} / \mathrm{m}^{2}$ \\
\hline
\end{tabular}

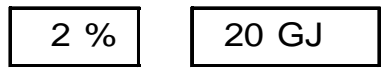

3 Timber building

\begin{tabular}{|c|c|c|}
\hline Total electricity & $257,433 \mathrm{kWh}$ & $927 \mathrm{GJ}$ \\
\hline Total Gas & $53,934 \mathrm{kWh}$ & $194 \mathrm{GJ}$ \\
\hline Total energy use: & 311,367 kWh & $1,121 \mathrm{GJ}$ \\
\hline Total energy use/m ${ }^{2}$ : & $88 \mathrm{kWh} / \mathrm{m}^{2}$ & $0.32 \mathrm{GJ} / \mathrm{m}^{2}$ \\
\hline
\end{tabular}

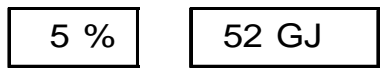

4 Timber-Plus building

\begin{tabular}{|c|c|c|}
\hline Total electricity & $247,271 \mathrm{kWh}$ & $890 \mathrm{GJ}$ \\
\hline Total Gas & $57,470 \mathrm{kWh}$ & 207 GJ \\
\hline Total energy use: & $304,740 \mathrm{kWh}$ & 1,097 GJ \\
\hline Total energy use/m ${ }^{2}$ : & $86 \mathrm{kWh} / \mathrm{m}^{2}$ & $0.31 \mathrm{GJ} / \mathrm{m}^{2}$ \\
\hline
\end{tabular}

Net usable area:

$3,536 \mathrm{~m}^{2}$

Table 4.1: Operating energy annual results

Electricity accounts for roughly $85 \%$ of the total energy consumed, with gas accounting for the remaining $15 \%$. This is because gas is used only for heating and domestic hot water while electricity is used for cooling, lighting, room electricity and miscellaneous systems (mainly the lift).

\subsubsection{Operating energy consumption benchmarks}

Several researchers have studied the energy consumption of commercial buildings in New Zealand. As a result of those studies, benchmarks of energy consumption in office buildings in New Zealand have been produced. The following section will present a summary of those studies. The aim of this section is to compare the results of these studies with the results produced by energy simulations undertaken in each of the four buildings in this thesis.

As was explained in Chapter 3, the buildings in this research aim for low energy consumption. The benchmarks that follow will help to 'position' all four buildings in this research and confirm that these are in 
fact low energy consumption buildings. These summaries are organised chronologically (oldest to newest), so the last study presented will set the most contemporary benchmark.

- Standards New Zealand (NZS) 4220:1982 "Code of practice for energy conservation in nonresidential buildings":

This standard set energy consumption targets for New Zealand's existing and new buildings. The target for office buildings is: existing buildings $200 \mathrm{kWh} / \mathrm{m}^{2}$.yr and new buildings $100 \mathrm{kWh} / \mathrm{m}^{2} . \mathrm{yr}$.

\section{- Property Council of New Zealand:}

The Property Council of New Zealand, in 2000, published a report named: Energy consumption benchmarks: an analysis of the energy expenses incurred by New Zealand CBD office buildings (Property Council of New Zealand, 2000). This study was undertaken between 1998 and 1999, to asses the cost and level of energy consumption in commercial CBD office buildings throughout New Zealand. The survey obtained the annual energy consumption statistics of 35 CBD office buildings encompassing approx $410,000 \mathrm{~m}^{2}$ of Net Lettable Area (the gross area less common areas and ancillary spaces).

The main findings are as follows:

- Total energy consumption ranged from less than $150 \mathrm{kWh} / \mathrm{m}^{2} . \mathrm{yr}$ to almost $450 \mathrm{kWh} / \mathrm{m}^{2} . \mathrm{yr}$.

- The combined average (gas and electricity) was $268.94 \mathrm{kWh} / \mathrm{m}^{2} . \mathrm{yr}$.

- The average level of gas consumption was $84.28 \mathrm{kWh} / \mathrm{m}^{2} . \mathrm{yr}$.

- The average level of electricity consumption was $222.12 \mathrm{kWh} / \mathrm{m}^{2} . \mathrm{yr}$.

Finally the study produced an energy performance indicator called the Energy Use Index (EUI) which provides a reference for buildings' energy consumption (in $\mathrm{kWh} / \mathrm{m}^{2}$.yr of NLA) of several building occupancy types. Table 4.2 shows the EUI values for office buildings with different indoor climate control systems.

\begin{tabular}{r|r|r|r|} 
Office building & \multicolumn{1}{l}{ Low } & \multicolumn{1}{l}{ Typical } & \multicolumn{1}{l}{ high } \\
\cline { 2 - 4 } With HVAC & $200 \mathrm{kWh} / \mathrm{m}^{2} \cdot \mathrm{yr}$ & $280 \mathrm{kWh} / \mathrm{m}^{2} \cdot \mathrm{yr}$ & $400 \mathrm{kWh} / \mathrm{m}^{2} \cdot \mathrm{yr}$ \\
\cline { 2 - 4 } Natural ventilated & $100 \mathrm{kWh} / \mathrm{m}^{2} \cdot \mathrm{yr}$ & $210 \mathrm{kWh} / \mathrm{m}^{2} \cdot \mathrm{yr}$ & $300 \mathrm{kWh} / \mathrm{m}^{2} \cdot \mathrm{yr}$ \\
\cline { 3 - 5 } Tenant electricity only & $60 \mathrm{kWh} / \mathrm{m}^{2} \cdot \mathrm{yr}$ & $150 \mathrm{kWh} / \mathrm{m}^{2} \cdot \mathrm{yr}$ & $200 \mathrm{kWh} / \mathrm{m}^{2} \cdot \mathrm{yr}$ \\
\cline { 3 - 5 } & &
\end{tabular}

Table 4.2: Property Council of New Zealand, 2000 Energy Use Index.

- NZ Green Building Council:

The NZGBC it is the newest energy use target in New Zealand Green Star (NZ sustainability rating tool). Green Star was launched in 2007 and rates the 'sustainability' of new and refurbished office buildings in New Zealand. It is a conditional requirement for obtaining a NZ Green Star, indicating that the base building design achieved an energy use figure of $120 \mathrm{kWh} / \mathrm{m}^{2} . \mathrm{yr}$ or less using the modelling method in NZS 4243/4218 (NZ Green Building Council, 2008).

- Summary of energy consumption benchmarks:

The predicted average energy consumption of the concrete, steel, timber and timber-plus buildings analysed in this thesis is $86 \mathrm{kWh} / \mathrm{m}^{2}$.yr. There is a tendency in simulations that the outcomes produced are lower than 


\section{Results}

the audited energy consumption during occupancy. It is not the aim of this thesis to identify the reasons for the gap between the predicted and audited outcomes, however, a figure of $84-86 \mathrm{kWh} / \mathrm{m}^{2} . \mathrm{yr}$ is well below the Standards New Zealand (NZS) 4220:1982, Property Council of New Zealand and the NZ Green Building Council benchmarks. 


\subsubsection{Operating energy segregated in end-uses:}

Table C.1 (Appendix C.1) shows the annual total energy consumed in operation broken down into five enduses for the concrete, steel, timber and timber-plus buildings.

The five end-uses mentioned in Table C.1 are:

- Room electricity - incorporating the plug loads from office equipment $\left(9 \mathrm{~W} / \mathrm{m}^{2}\right)$.

- Lighting - incorporating the lighting of offices $\left(13.6 \mathrm{~W} / \mathrm{m}^{2}\right)$, corridors and service areas $\left(3.4 \mathrm{~W} / \mathrm{m}^{2}\right)$.

- System miscellaneous includes mainly the lift/elevator $\left(4 \mathrm{kWh} / \mathrm{m}^{2}\right)$.

- Domestic hot water (simulated as $4 \mathrm{kWh} / \mathrm{m}^{2}$ ).

- Heating

- Cooling

From all five end-uses, heating and cooling consumption vary the most between each of the four buildings in this research; the other end-uses do not vary significantly between buildings (there is a negligible variation in room electricity).

It can be said that the energy consumed in room electricity, lighting, system miscellaneous and domestic hot water is not driven by buildings materials. The energy consumption in those items might be driven by the architectural design of the buildings and the performance of the systems and equipment used. This is important, because when looking at Table C.1, the building materials can only influence the energy use of heating and cooling operations, which is only $25 \%$ to $27 \%$ of the total energy consumption in operations of the buildings. Figure 4.1 shows, for the concrete, steel, timber and timber-plus buildings, the proportion breakdown of the end-uses energy consumption.

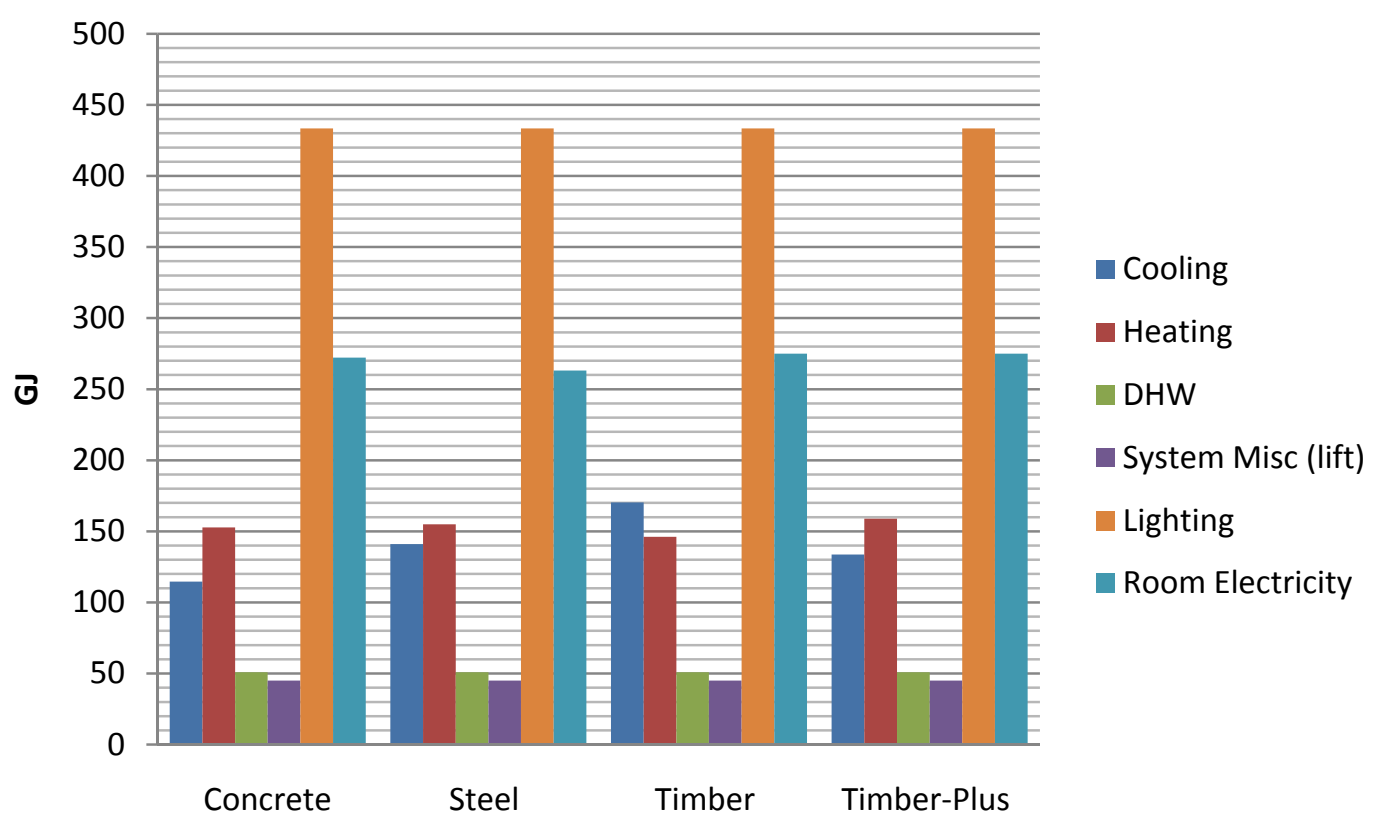

Figure 4-1: Annual operational energy segregated into end-uses for the concrete, steel, timber and timber-plus buildings.

It can be seen that for all buildings, lighting energy consumption $(120,403 \mathrm{kWh} / \mathrm{yr})$ is by far the largest energy end-use accounting for roughly $40 \%$ of the total energy consumption. Other end-uses are room 
electricity $(75,610 \mathrm{kWh} / \mathrm{yr})$, accounting for $25 \%$ of the total energy consumption, then cooling, ranging from $11 \%(31,831 \mathrm{kWh} / \mathrm{yr})$ in the concrete building to $15 \%(47,304 \mathrm{kWh} / \mathrm{yr})$ in the timber building, and heating accounting for $12 \%$ to $13 \%$ (average $41,822 \mathrm{kWh} / \mathrm{yr}$ ) for all buildings. Domestic hot water $(14,146 \mathrm{kWh} / \mathrm{yr}$ ) and system miscellaneous $(12,509 \mathrm{kWh} / \mathrm{yr})$ account for $4 \%$ to $5 \%$ each. Heating and cooling, added together, range from $25 \%$ in the concrete building $(47,268 \mathrm{kWh} / \mathrm{yr})$ to $28 \%$ in the timber building $(87,911$ $\mathrm{kWh} / \mathrm{yr}$ ), this is roughly the same proportion as room electricity. Lighting alone is larger than both cooling and heating energy consumption added together. The specific values of energy consumption produce under energy performance simulation of all end-uses in the buildings are presented in Table C.1 in (Appendix C).

Table 4.3 presents the distribution of energy end-uses from BETARG for New Zealand office buildings, published in "Energy Use Indices" (Bishop, 1992).

\begin{tabular}{|c|l|c|cccccc|}
\hline Country & Source & Total & Lighting & Heating & Cooling & $\begin{array}{c}\text { HVAC } \\
\text { Aux. }\end{array}$ & $\begin{array}{c}\text { Hot } \\
\text { Water }\end{array}$ & Other \\
\hline N.Z. & $\begin{array}{l}\text { BETARG } \\
\text { (Large, base) }\end{array}$ & 130 & 49 & 49 & 7 & - & 3 & 21 \\
N.Z. & $\begin{array}{l}\text { BETARG } \\
\text { (Small, base) }\end{array}$ & 130 & 49 & 67 & 3 & - & 3 & 4 \\
\hline
\end{tabular}

Table 4.3: Office buildings energy end-use distributions in New Zealand (Bishop, 1992).

Table 4.4 presents detailed office building end-use benchmarks from energy efficiency in buildings, CIBSE Guide F (CIBSE, 2006). The table is from the UK and there is considerable climatic bias to the energy enduse estimates. For example, UK data (CIBSE) shows consistently higher amounts of heating energy than in NZ.

\begin{tabular}{|c|c|c|c|c|c|c|}
\hline \multirow[t]{3}{*}{ System } & \multicolumn{6}{|c|}{ Delivered energy for stated office types $/ \mathrm{kWh} / \mathrm{m}^{2 \star} \mathrm{yr}$} \\
\hline & \multicolumn{2}{|l|}{ Type 2} & \multicolumn{2}{|l|}{ Type 3} & \multicolumn{2}{|l|}{ Type 4} \\
\hline & $\begin{array}{l}\text { Good } \\
\text { practice }\end{array}$ & Typical & $\begin{array}{l}\text { Good } \\
\text { practice }\end{array}$ & Typical & $\begin{array}{c}\text { Good } \\
\text { practice }\end{array}$ & Typical \\
\hline $\begin{array}{l}\text { Gas/oil heating } \\
\text { and hot water }\end{array}$ & 79 & 151 & 97 & 178 & 107 & 201 \\
\hline Catering gas & 0 & 0 & 0 & 0 & 7 & 9 \\
\hline cooling & 1 & 2 & 14 & 31 & 21 & 41 \\
\hline Fans, pump and controls & 4 & 8 & 30 & 60 & 36 & 67 \\
\hline Humidification & 0 & 0 & 8 & 18 & 12 & 23 \\
\hline Lighting & 22 & 38 & 27 & 54 & 29 & 60 \\
\hline Office equipment & 20 & 27 & 23 & 31 & 23 & 32 \\
\hline Catering electricity & 3 & 5 & 5 & 6 & 13 & 15 \\
\hline Other electricity & 4 & 5 & 7 & 8 & 13 & 15 \\
\hline computer room & 0 & 0 & 14 & 18 & 87 & 105 \\
\hline Total gas or oil & 79 & 151 & 97 & 178 & 114 & 210 \\
\hline Total electricity & 54 & 85 & 128 & 226 & 234 & 358 \\
\hline
\end{tabular}

Note: Type 2 : open plan naturally ventilated; Type 3: 'standard' air conditioned;

Type 4: 'prestige' air conditioned

Table 4.4: Office buildings energy end-use distribution in the UK (CIBSE, 2006) 
As can be seen in Table 4.3, for an office building in New Zealand, $49 \mathrm{kWh} / \mathrm{m}^{2} . \mathrm{yr}$ would be used in lighting. For a naturally ventilated building in the UK, lighting ranges between 22 and $38 \mathrm{kWh} / \mathrm{m}^{2} . \mathrm{yr}$ and for a building with 'standard' air conditioned the range is between 27 and $54 \mathrm{kWh} / \mathrm{m}^{2} . \mathrm{yr}$. Buildings analysed in this thesis used $34 \mathrm{kWh} / \mathrm{m}^{2}$.yr for lighting), which is similar to the consumption for lighting for New Zealand offices, and a typical open plan naturally ventilated or a good practice 'standard' or 'prestige' air conditioned office building in the UK.

When looking at heating energy consumption, New Zealand buildings range from 49 to $67 \mathrm{kWh} / \mathrm{m}^{2} . \mathrm{yr}$ and UK buildings range from $79 \mathrm{kWh} / \mathrm{m}^{2} . \mathrm{yr}$ in an open plan naturally ventilated office building to $201 \mathrm{kWh} / \mathrm{m}^{2} . \mathrm{yr}$ in a 'prestige' air conditioned office building. Both the New Zealand and UK benchmarks are larger than the 12 $\mathrm{kWh} / \mathrm{m}^{2}$.yr used in the buildings simulated in this thesis.

Cooling takes up 3 to $7 \mathrm{kWh} / \mathrm{m}^{2}$.yr for the New Zealand buildings and ranges from $14 \mathrm{kWh} / \mathrm{m}^{2}$.yr in a good practice 'standard' air conditioned building to $41 \mathrm{kWh} / \mathrm{m}^{2} . \mathrm{yr}$ in a common practice 'prestige' air conditioned building in the UK. Buildings simulated in this thesis average $11 \mathrm{kWh} / \mathrm{m}^{2} . \mathrm{yr}$ of energy consumption in cooling, which is higher than the $7 \mathrm{kWh} / \mathrm{m}^{2}$.yr consumed in a New Zealand building, but similar to the cooling consumption of a good practice 'standard' air conditioned building in the UK.

These end-uses benchmarks are used as validation of the outcomes produced by the energy simulations undertaken on all buildings in this thesis. Since there is no data for office buildings specifically in Christchurch, some differences in the benchmarks might be produced, especially for heating energy consumption, where both New Zealand and the UK had a higher consumption than the buildings simulated in this thesis. This might be because the numbers for New Zealand Buildings published in Table 4.3 are produced in the BETARG (NZ). "Although the BETARG target may seem low, when compared to actual measured energy use indices, they represent an attempt to quantify "best practice" in building design and management" (Bishop, 1992). On the other hand, lighting and cooling energy consumption produced in simulation were similar to both New Zealand's and the UK's benchmarks. 


\subsubsection{Heating and cooling end-uses}

Figure 4.2 shows, for the concrete, steel, timber and timber-plus buildings, the proportion of annual energy used in cooling and heating expressed in GJ.

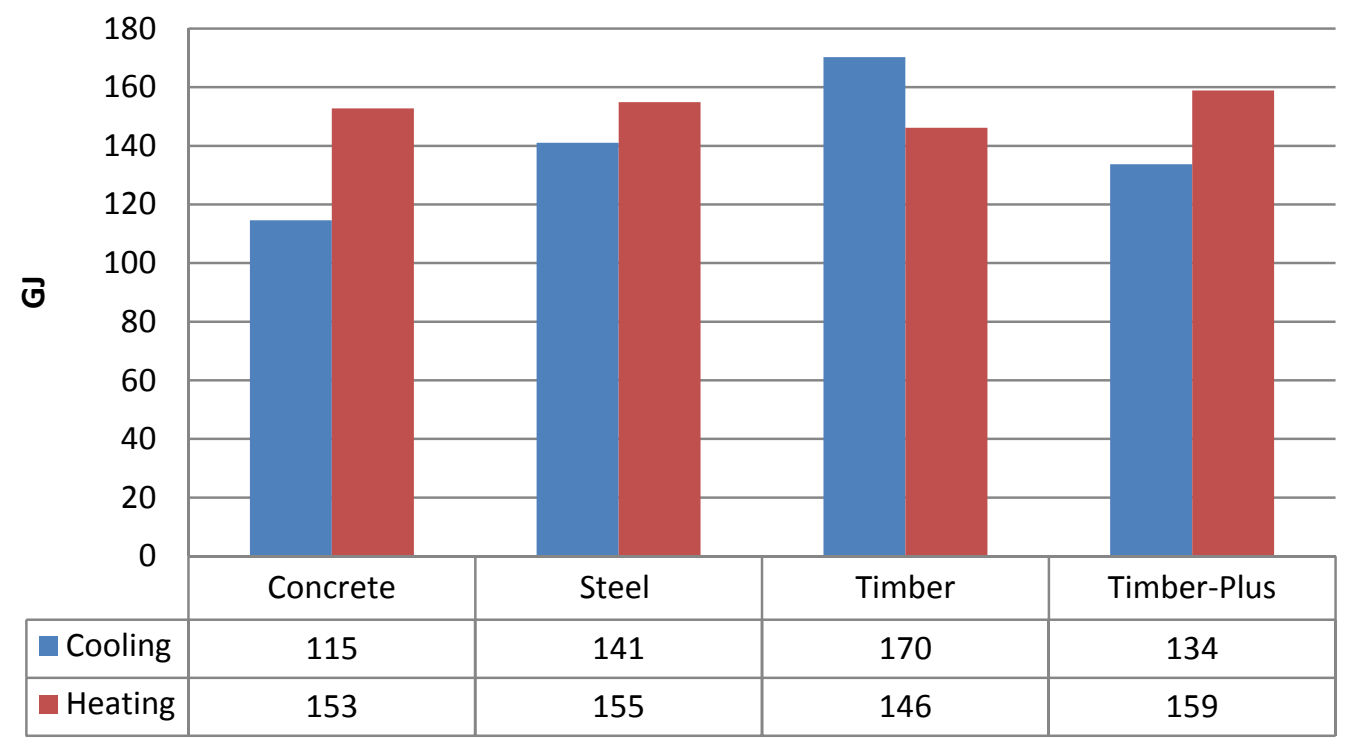

Figure 4-2: Annual energy consumption for heating and cooling for the concrete, steel, timber and timber-plus building.

As it was said before, heating and cooling are the only two end-uses that vary regarded building materials. Cooling energy consumption varies significantly between each of the four buildings, while heating energy consumption remains fairly stable with only small variations between buildings. Cooling energy use ranges from $115 \mathrm{GJ} / \mathrm{yr}$ to $170 \mathrm{GJ} / \mathrm{yr}$ (55 GJ/yr range), while the heating energy use ranges from $146 \mathrm{GJ} / \mathrm{yr}$ to 159 $\mathrm{GJ} / \mathrm{yr}$ (13 GJ/yr range). Only in the timber building is the trend inverted with the largest energy consumption for cooling (170 GJ/yr) and the lowest (146 GJ/yr) for heating.

One reason for these differences is in the implications of structural elements used in the envelope walls. As explained in Section 3.4.1.2 (Building's thermal envelope description), the main structural system of the steel building was left inside the offices so that it wouldn't drastically increase the heat losses. On the other hand, in the concrete, timber and timber-plus buildings the structural systems are rather similar and the shear walls are part of the structural system. In the concrete building there is a layer of extruded polyurethane in the core of the structural walls but in the timber and timber-plus buildings no extra insulation has been added to the shear walls. The influence of structural components in the thermal envelope acts as thermal bridges and increases the heat losses through the wall.

The second and most important reason for the differences in the building's energy consumption of cooling and heating is due to the influence of thermal mass. Of the four buildings analysed in this thesis, the timber building contains the lowest amount of concrete in the building construction materials and subsequently has the higher cooling load and the shortest heating load. There is only a $60 \mathrm{~mm}$ thick layer of reinforced concrete as part of the composite plywood-concrete suspended floors. In comparison, the concrete building has a 


\section{Results}

suspended floor, which is a $300 \mathrm{~mm}$ hollow core concrete slab with $100 \mathrm{~mm}$ concrete toping, and subsequently has the shortest cooling load and the second shortest heating load.

The influence of structural components acting as thermal bridges and the differences in the amount of thermal mass are responsible for the different performance in cooling and heating energy consumptions of the concrete, steel, timber and timber-plus buildings. When looking at Figure 4.2, it is possible to say that for office buildings in Christchurch, when volumes of concrete are involved in the building, the energy use for heating increases and the energy use for cooling reduces. In order to asses the influence of thermal mass, the following section will further study the comparison between the concrete and timber buildings as cases representative of a high and low mass building respectively. 


\subsubsection{Comparison between the concrete and timber buildings as examples of a high and low thermal mass buildings respectively}

As explained in previously, the timber building is the building that contains the smallest amount of concrete acting as a thermal mass. On the other hand the concrete building represents the opposite, being the building with the largest amount of concrete acting as a thermal mass. In order to illustrate the influence of a thermal mass, this section will present the results of a comparison of the graph produced during the operating energy simulation process for the timber and the concrete buildings, where internal operative temperatures are presented during the Winter and Summer average weeks.

Graphs of this comparison are presented in Appendix C.2; these compare the internal operative temperature of the concrete building and the outside Dry-Bulb temperature in Figure C.1 and C.3. The concrete building is then compared with the timber building in figure C.2 and C.4. Inside operative temperature is the average between the internal radiant temperature and the internal air temperature. For the concrete and the timber buildings, their operative temperature was taken from the building's fourth level offices zone.

Table 4.5 shows, for the concrete and the timber buildings, the total design cooling requirement and the total design heat loss. This data is used to estimate the size of the heating and cooling equipment required for each building.

\begin{tabular}{cll|} 
Concrete building: & $\begin{array}{l}\text { Total design cooling requirement } \\
\text { Total design heating requirement }\end{array}$ & $164.87 \mathrm{~kW}$ \\
& & $140.85 \mathrm{~kW}$ \\
Timber building: & Total design cooling requirement & $208.95 \mathrm{~kW}$ \\
& Total design heating requirement & $136.14 \mathrm{~kW}$ \\
\hline
\end{tabular}

Table 4.5: Concrete and timber buildings' total design cooling requirement and total design heat loss.

As can be seen, the total design heat losses are fairly similar between the concrete and the timber buildings. The difference is larger in the total design cooling load requirement, as the required load is $44 \mathrm{~kW}$ larger for the timber building.

As can be seen in figure C.1; the highest temperature during the average summer week was $30^{\circ} \mathrm{C}$ at $2 \mathrm{pm}$ on the $16^{\text {th }}$ of January and the lowest temperature was $9^{\circ} \mathrm{C}$ at 5 am on the $17^{\text {th }}$ of January. The operative temperature inside the buildings remains stable within roughly $2^{\circ} \mathrm{C}$, with an average maximum of $27.5^{\circ} \mathrm{C}$ and minimum of $25.3^{\circ} \mathrm{C}$. It can be seen in figure C. 3 that for average weeks in winter outside temperatures vary up to $13^{\circ} \mathrm{C}$ between day and night. The highest temperature during the week was $14^{\circ} \mathrm{C}$ at midday on the $9^{\text {th }}$ of July and the lowest temperature was $-1.9^{\circ} \mathrm{C}$ at 6 am on the $4^{\text {th }}$ of July. The operative temperature inside the buildings remains stable, within roughly $5^{\circ} \mathrm{C}$, from an average maximum of $22.7^{\circ} \mathrm{C}$ and a minimum of $17.6^{\circ} \mathrm{C}$.

As in Figure C.2, in Figure C.4 the concrete building (solid line) has a smaller variation between the lower temperature at night and the highest temperature during the afternoon than the timber building. Both 
buildings heating systems work at 100\% from 8 am until 6 pm. Particularly in figure C.4 (summer) both buildings reach $26^{\circ} \mathrm{C}$ (cooling set point) at around the same time during the day ( $8 \mathrm{am}$ ) and run at a constant of $26^{\circ} \mathrm{C}$ until $6 \mathrm{pm}$. The design cooling requirement in the concrete building is $165 \mathrm{~kW}$ and in the timber building it is $209 \mathrm{~kW}$. Despite the fact that the buildings use air conditioning for roughly the same time period during the day, the concrete building uses $44 \mathrm{~kW}$ less to keep the temperature constant at $26^{\circ} \mathrm{C}$.

The total design heating requirement in the concrete building is $141 \mathrm{~kW}$ and in the timber building is $136 \mathrm{~kW}$. It can be seen in Figure C.2 that during office hours, when heating is working at full capacity, the timber building increases the internal operative temperature further than the concrete building, despite having a $5 \mathrm{~kW}$ lower total design heat loss. Based on Figures C.2 and C.4, it can be said that the most significant effect of thermal mass is that this absorbs the excessive heat produce inside the building. This is beneficial in summer because the building absorbs part of the heat inside the building, which helps to decrease the total design cooling requirement. In winter the same effect produce an increment on the total design heat loss. The timber building performs better in winter, but because of the absence of thermal mass, suffers from overheating in summer. This manifests itself in a much higher total design cooling requirement which makes the overall performance drop compared to the high mass building. 


\subsubsection{Life-cycle operating energy use}

Table 4.6 shows, for the concrete, steel, timber and timber-plus buildings, the annual energy use in operation multiplied by a 60 year life-cycle. The life-cycle energy consumption is presented in $\mathrm{GJ}$ and the total is then divided by the building's Net Usable Area.

Annual energy consumed in operation

kWh

1 Concrete building

\begin{tabular}{|l|r|}
\hline Total energy use: & $296,935 \mathrm{kWh} / \mathrm{yr}$ \\
\hline Total energy use $/ \mathrm{m}^{2}:$ & $84 \mathrm{kWh} / \mathrm{m}^{2} \cdot \mathrm{yr}$ \\
\hline
\end{tabular}

2 Steel building

\begin{tabular}{|l|r|}
\hline Total energy use: & $302,363 \mathrm{kWh} / \mathrm{yr}$ \\
\hline Total energy use $/ \mathrm{m}^{2}:$ & $86 \mathrm{kWh} / \mathrm{m}^{2} . \mathrm{yr}$ \\
\hline
\end{tabular}

3 Timber building

\begin{tabular}{|l|r|}
\hline Total energy use: & $311,367 \mathrm{kWh} / \mathrm{yr}$ \\
\hline Total energy use $/ \mathrm{m}^{2}:$ & $88 \mathrm{kWh} / \mathrm{m}^{2} \cdot \mathrm{yr}$ \\
\hline
\end{tabular}

4 Timber-Plus building

\begin{tabular}{|l|r|}
\hline Total energy use: & $304,740 \mathrm{kWh} / \mathrm{yr}$ \\
\hline Total energy use $/ \mathrm{m}^{2}:$ & $86 \mathrm{kWh} / \mathrm{m}^{2} . \mathrm{yr}$ \\
\hline
\end{tabular}

\begin{tabular}{|c|}
\hline $1,069 \mathrm{GJ} / \mathrm{yr}$ \\
\hline $0.30 \mathrm{GJ} / \mathrm{m}^{2} \cdot \mathrm{yr}$ \\
\hline
\end{tabular}

GJ

\begin{tabular}{|l|}
\hline $1,089 \mathrm{GJ} / \mathrm{yr}$ \\
\hline $0.31 \mathrm{GJ} / \mathrm{m}^{2} \cdot \mathrm{yr}$ \\
\hline
\end{tabular}

\begin{tabular}{|l|}
\hline $1,121 \mathrm{GJ} / \mathrm{yr}$ \\
\hline $0.32 \mathrm{GJ} / \mathrm{m}^{2} \cdot \mathrm{yr}$ \\
\hline
\end{tabular}

\begin{tabular}{|l|}
\hline $1,097 \mathrm{GJ} / \mathrm{yr}$ \\
\hline $0.31 \mathrm{GJ} / \mathrm{m}^{2} \cdot \mathrm{yr}$ \\
\hline
\end{tabular}

60 year life-cycle

GJ

\begin{tabular}{|c|}
\hline $64,138 \mathrm{GJ}$ \\
\hline $18.1 \mathrm{GJ} / \mathrm{m}^{2}$
\end{tabular}

\begin{tabular}{|c|}
\hline $65,310 \mathrm{GJ}$ \\
\hline $18.5 \mathrm{GJ} / \mathrm{m}^{2}$ \\
\hline
\end{tabular}

\begin{tabular}{|c|}
\hline $67,255 \mathrm{GJ}$ \\
\hline $19.0 \mathrm{GJ} / \mathrm{m}^{2}$ \\
\hline
\end{tabular}

\begin{tabular}{|c|}
\hline $65,824 \mathrm{GJ}$ \\
\hline $18.6 \mathrm{GJ} / \mathrm{m}^{2}$ \\
\hline
\end{tabular}

Net Usable Area:

$3,536 \mathrm{~m}^{2}$

Table 4.6: Energy consumed in operations, annual and 60 year life-cycle consumption in GJ

As can be seen, the concrete building has the lowest life-cycle operational energy consumption (64,138 GJ). Next is the steel building which is $1.8 \%(1,172 \mathrm{GJ})$ higher, then the timber-plus building which is $2.6 \%(1,686$ GJ) higher and finally the timber building which has a $4.8 \%$ (3,117 GJ) higher life-cycle energy consumption in operations than the concrete building. Life-cycle operational energy consumption is very similar between the steel and the timber-plus building; the timber-plus building has an energy consumption only $0.8 \%$ (514 GJ) higher than the steel building. The 60 year life-cycle operational energy consumption difference between the concrete building (lowest consumption) and the timber building (highest consumption) is $3,117 \mathrm{GJ}$.

As it was explained in Section 4.1.1.3 (Heating and cooling end-uses), the difference between operational energy consumption is due to the influence of structural components within envelope walls acting as thermal bridges, but mostly due to the amount of concrete (acting as a thermal mass) used in the building. The difference in the consumption between the timber and timber-plus buildings is due to the influence of solid wood in the partitions, external walls and ceiling acting as a thermal mass - storing and exchanging heat (Bellamy \& Mackenzie, 2007). 


\subsubsection{Embodied energy}

As explained in Section 3.5.2.1 (LCA scope in this research), the initial plan of this research was to analyse the initial and recurrent embodied energy of the concrete, steel, timber and timber-plus building applying the New Zealand-specific data (Alcorn 2003). A parallel research emerged, carried out by Scion Research. The Scion research produced a complete LCA of the concrete, steel, timber and timber-plus buildings but using the GaBi 4.2 professional LCA tool. Due to this, this section will present the data of the initial and recurrent embodied energy and initial and recurrent $\mathrm{CO}_{2}$ emissions segregated between the results produced using the Alcorn and the GaBi databases. These parallel sets of results provide the opportunity to evaluate the influence of the LCl database used in the final LCA outcome. Also important is assessing the differences in the results produce by New Zealand-specific data and overseas data.

Figure 4.3 shows two different graphs: one contains the results produced using the GaBi database (on the left) and the other the results produced using the Alcorn Database (on the right). Results in both graphs show the initial and recurrent embodied energy together in single column for the concrete, steel, timber and timber-plus buildings.
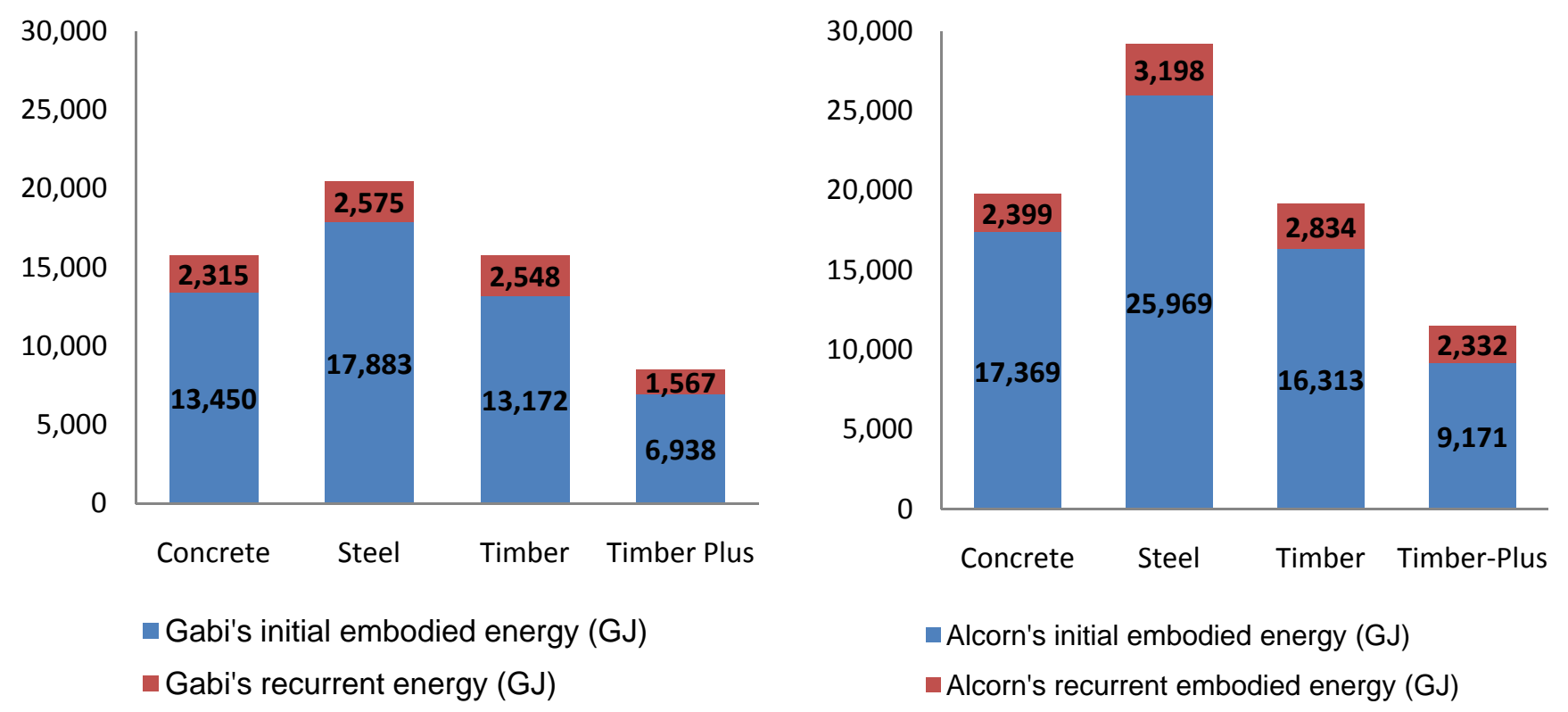

Figure 4-3: Initial and recurrent embodied energy for the concrete, steel, timber and timber-plus buildings are presented in two parallel graphs, showing the results produced using the GaBi and the Alcorn database.

There are significant differences between total embodied energy results based on the two sets of coefficients. In all cases, results produced using Alcorn are on average 32\% higher than results produced using GaBi:

- For the concrete building Alcorn is $25 \%$ higher than $\mathrm{GaBi}$.

- For the steel building Alcorn is $43 \%$ higher than GaBi.

- For the timber building, Alcorn is $22 \%$ higher than GaBi. 
- $\quad$ For the timber-plus building, Alcorn is 36\% higher than GaBi.

As explained in Chapter 3, section 3.5.2.1(LCA scope in this research) Szalay and Nebel (2006) and Nebel (2007) found that Alcorn data is in a range between $20 \%$ and $350 \%$ of the overseas data (GaBi included) with no general trend for Alcorn data to be lower or higher than overseas data. When looking at the GaBi and the Alcorn databases together, it can be seen that some buildings materials such as aluminium and timber, in the New Zealand data, are lower, and for others such as cement, gypsum board or steel the results are higher (See Table B.4 in Appendix B). Nevertheless this thesis found that results produced using the GaBi database are considerably lower than the results produced using the Alcorn database for all four buildings analysed.

The main reasons for differences in the GaBi and the Alcorn database, provided in the researches of both Szalay and Nebel (2006) and Nebel (2007). are organised into the following three headings:

- Country/region related differences

- Differences in inventory analysis

- Impact assessment categories

Detailed descriptions of these differences can be found in Chapter 3 Section 3.5.2.1 nevertheless the differences most closely related to embodied energy are the transport distances under 'Country/region related differences' and the difference in system boundaries of data under 'Differences in inventory analysis'. Transport distances are one reason for the differences, particularly in New Zealand where a number of raw materials have to be shipped from overseas. Subsequently the transport-related energy requirements results are higher for New Zealand than for Germany. Differences in system boundaries of data are often different between the two databases; one significant difference is in the ratio of recycling scrap and virgin steel mix in metal production. For copper values for example, the Alcorn data relates to virgin copper, while in the GaBi a ratio of $40 \%$ of recycling scrap and $60 \%$ virgin is used respectively (Szalay \& Nebel, 2006). 


\subsubsection{Ranking of building's total embodied energy}

Table 4.7 shows, for the concrete, steel, timber and timber-plus buildings, the total embodied energy resulting from the addition of the initial embodied energy and the recurrent embodied energy for a life-cycle of 60 years.

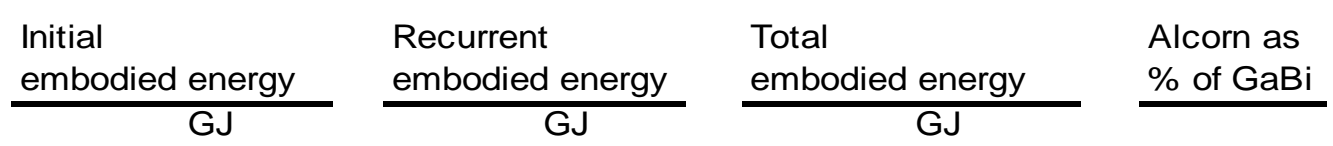

\section{Concrete building}

\begin{tabular}{|c|c|c|c|c|c|c|c|}
\hline \multirow[t]{2}{*}{ Gabi } & $13,450 \mathrm{GJ}$ & \multirow[t]{2}{*}{$85 \%$} & $2,315 \mathrm{GJ}$ & \multirow[t]{2}{*}{$15 \%$} & 15,765 GJ & \multirow{2}{*}{\multicolumn{2}{|c|}{$100 \%$}} \\
\hline & $3.80 \mathrm{GJ} / \mathrm{m}^{2}$ & & $0.65 \mathrm{GJ} / \mathrm{m}^{2}$ & & $4.46 \mathrm{GJ} / \mathrm{m}^{2}$ & & \\
\hline \multirow[t]{2}{*}{ Alcorn } & $17,369 \mathrm{GJ}$ & \multirow[t]{2}{*}{$88 \%$} & 2,399 GJ & \multirow[t]{2}{*}{$12 \%$} & 19,768 GJ & \multirow[t]{2}{*}{$100 \%$} & \multirow[t]{2}{*}{$125 \%$} \\
\hline & $4.91 \mathrm{GJ} / \mathrm{m}^{2}$ & & $0.68 \mathrm{GJ} / \mathrm{m}^{2}$ & & $5.59 \mathrm{GJ} / \mathrm{m}^{2}$ & & \\
\hline
\end{tabular}

2 Steel building

\begin{tabular}{|c|c|c|c|c|c|c|c|}
\hline \multirow[t]{2}{*}{ Gabi } & $17,883 \mathrm{GJ}$ & \multirow[t]{2}{*}{$87 \%$} & $2,575 \mathrm{GJ}$ & \multirow[t]{2}{*}{$13 \%$} & 20,457 GJ & \multirow{2}{*}{\multicolumn{2}{|c|}{$100 \%$}} \\
\hline & $5.06 \mathrm{GJ} / \mathrm{m}^{2}$ & & $0.73 \mathrm{GJ} / \mathrm{m}^{2}$ & & $5.79 \mathrm{GJ} / \mathrm{m}^{2}$ & & \\
\hline \multirow[t]{2}{*}{ Alcorn } & $25,969 \mathrm{GJ}$ & \multirow[t]{2}{*}{$89 \%$} & $3,198 \mathrm{GJ}$ & \multirow[t]{2}{*}{$11 \%$} & $29,167 \mathrm{GJ}$ & \multirow[t]{2}{*}{$100 \%$} & \multirow[t]{2}{*}{$143 \%$} \\
\hline & $7.34 \mathrm{GJ} / \mathrm{m}^{2}$ & & $0.90 \mathrm{GJ} / \mathrm{m}^{2}$ & & $8.25 \mathrm{GJ} / \mathrm{m}^{2}$ & & \\
\hline
\end{tabular}

3 Timber building

\begin{tabular}{|c|c|c|c|c|c|c|c|}
\hline \multirow[t]{2}{*}{ Gabi } & 13,172 GJ & \multirow[t]{2}{*}{$83 \%$} & $2,728 \mathrm{GJ}$ & \multirow[t]{2}{*}{$17 \%$} & $15,900 \mathrm{GJ}$ & \multirow{2}{*}{\multicolumn{2}{|c|}{$100 \%$}} \\
\hline & $3.73 \mathrm{GJ} / \mathrm{m}^{2}$ & & $0.77 \mathrm{GJ} / \mathrm{m}^{2}$ & & $4.50 \mathrm{GJ} / \mathrm{m}^{2}$ & & \\
\hline \multirow[t]{2}{*}{ Alcorn } & $16,313 \mathrm{GJ}$ & \multirow[t]{2}{*}{$84 \%$} & $3,163 \mathrm{GJ}$ & \multirow[t]{2}{*}{$16 \%$} & $19,476 \mathrm{GJ}$ & \multirow[t]{2}{*}{$100 \%$} & \multirow[t]{2}{*}{$122 \%$} \\
\hline & $4.61 \mathrm{GJ} / \mathrm{m}^{2}$ & & $0.89 \mathrm{GJ} / \mathrm{m}^{2}$ & & $5.51 \mathrm{GJ} / \mathrm{m}^{2}$ & & \\
\hline
\end{tabular}

4 Timber-Plus building

\begin{tabular}{|c|c|c|c|c|c|c|c|}
\hline \multirow{2}{*}{ Gabi } & $6,938 \mathrm{GJ}$ & \multirow[t]{2}{*}{$80 \%$} & $1,747 \mathrm{GJ}$ & \multirow[t]{2}{*}{$20 \%$} & 8,685 GJ & \multirow{2}{*}{\multicolumn{2}{|c|}{$100 \%$}} \\
\hline & $1.96 \mathrm{GJ} / \mathrm{m}^{2}$ & & $0.49 \mathrm{GJ} / \mathrm{m}^{2}$ & & $2.46 \mathrm{GJ} / \mathrm{m}^{2}$ & & \\
\hline \multirow[t]{2}{*}{ Alcorn } & $9,171 \mathrm{GJ}$ & \multirow[t]{2}{*}{$78 \%$} & 2,661 GJ & \multirow[t]{2}{*}{$22 \%$} & 11,832 GJ & \multirow[t]{2}{*}{$100 \%$} & \multirow[t]{2}{*}{$136 \%$} \\
\hline & $2.59 \mathrm{GJ} / \mathrm{m}^{2}$ & & $0.75 \mathrm{GJ} / \mathrm{m}^{2}$ & & $3.35 \mathrm{GJ} / \mathrm{m}^{2}$ & & \\
\hline
\end{tabular}

Net Usable Area: $3,536 \mathrm{~m}^{2}$

Table 4.7: Total embodied energy segregated into initial and recurrent embodied energy using coefficients of embodied energy from two different sources (Gabi software and Alcorn (2003)).

For both $\mathrm{GaBi}$ and Alcorn results, initial embodied energy represents $84-85 \%$ and recurrent embodied energy the remaining $16-15 \%$. When looking at buildings' total embodied energy with $\mathrm{GaBi}$, the timber-plus building has the lowest total embodied energy $(8,686 \mathrm{GJ})$, and followed by the concrete building which is $7,080 \mathrm{GJ}$ higher than the timber-plus building, the timber building is next at 7,215 GJ higher and finally the steel building at $11,772 \mathrm{GJ}$ higher than the timber-plus building.

When looking at the results gathered using Alcorn data, the trend changes slightly. The lowest total embodied energy is also the timber-plus building with $11,832 \mathrm{GJ}$. The timber building is next at 7,643 GJ higher than the timber-plus building, followed by the concrete building which is $7936 \mathrm{GJ}$ higher, and again 
the highest total embodied energy is in the steel building, being $17,335 \mathrm{GJ}$ higher than the timber-plus building.

The differences in the trend between the results produced using GaBi's or Alcorn's data are in the concrete and timber buildings. With GaBi's data, the total embodied energy is $1 \%$ higher for the timber building compared to the concrete building. With Alcorn's data, the total embodied energy is $2 \%$ higher for the concrete building compared to the timber building. There is more embodied energy in material here in New Zealand (Alcorn) than the materials produced in Germany (GaBi). This might be due to the more energy efficient building material manufacturing process in Germany.

The following section will analyse the initial embodied energy, but segregated in buildings components. The aim is to assess which component has the highest embodied energy and then assess the influence of each component on the total building's initial embodied energy. 


\subsubsection{Buildings components' initial embodied energy}

Table 4.8 shows, in the left column, the original 12 items into which the quantity surveyor (QS) organised the schedules of materials for each of the buildings. These are either very small items such as doors or very large ones such as structure. A list of all the materials involved in each of the 12 items was calculated by the QS. The left column shows five major building components. Each of these five components incorporates between two and three of the QS's items.

\section{QS Items}

\begin{tabular}{|l|}
\hline 1) Foundations \\
2) Ground Floor Slabs \\
\hline 3) Suspended floors \\
4) Structure: \\
5) Stairs \\
\hline 6) Roof \\
7) Exterior walls \\
\hline 8) Doors \\
9) Interior wall \\
10) Ceiling \\
\hline 11) Louvers \\
12) Windows \\
\hline
\end{tabular}

\section{Building component}
1) Foundation
2) Structural system
3) Envelope
4) Interior finishes
5) Windows and louvers

Table 4.8: Buildings' items in the schedule of materials organised into five main buildings components.

Figure 4.4 shows, for the concrete, steel, timber and timber-plus buildings (using the GaBi database), the total embodied energy for each of the five buildings components.

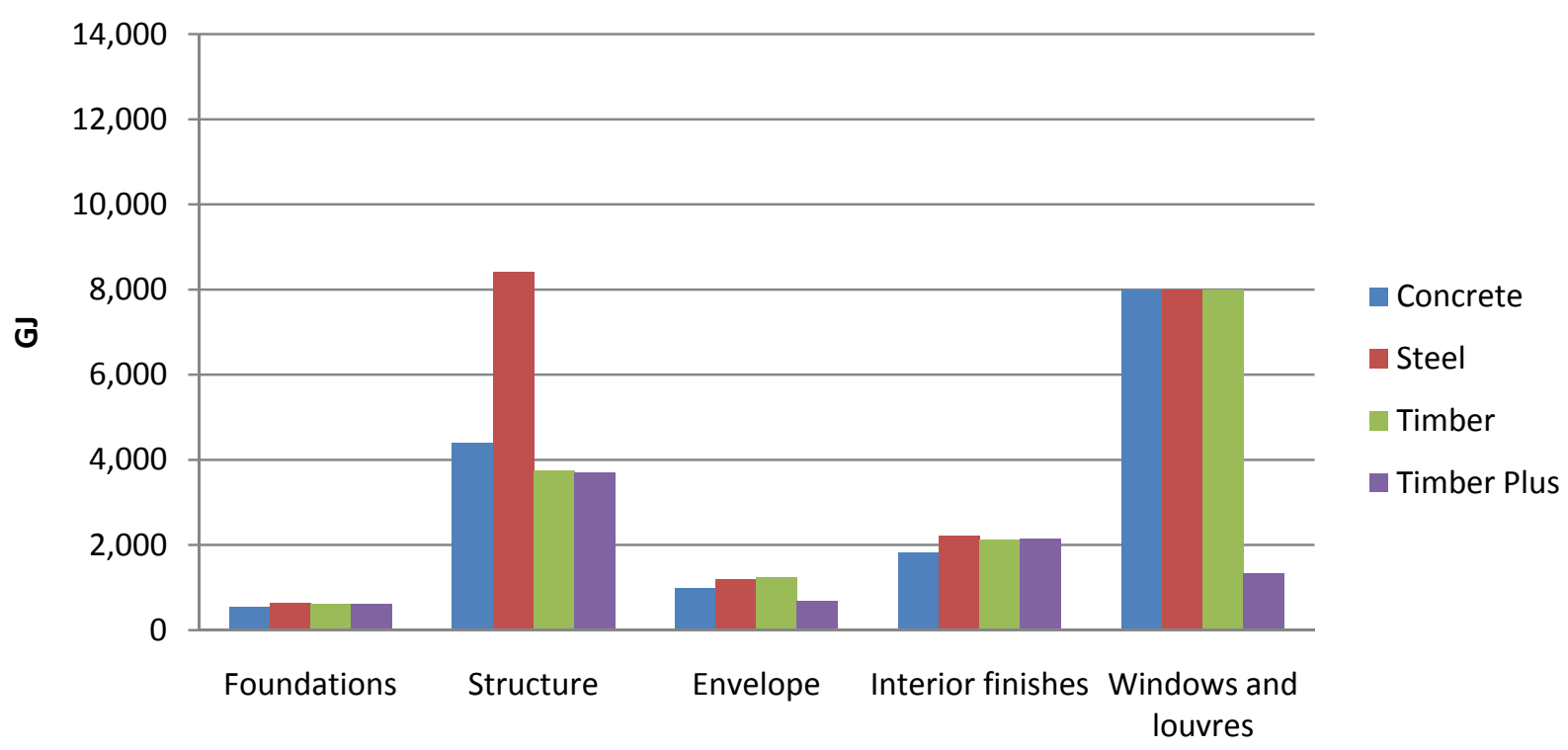

Figure 4-4: Total embodied energy segregated into five major building components (foundations, structure, envelope, interior finishes and windows and louvers) for the concrete, steel, timber and timber-plus buildings (using the GaBi database). 
The highest embodied energy contribution (roughly $50 \%$ of initial embodied energy) is from windows and louvers (7,995 GJ); only in the case of the timber-plus building $(1,347 \mathrm{GJ})$ is the embodied energy in that component significantly lower than in the concrete, steel and timber buildings. As was explained in the methodology chapter, the concrete, steel and timber buildings use the same window and louver systems. However, in the timber-plus building the louvers were changed from aluminium to cedar. The manufacture of aluminium is an energy intensive process, particularly the process of electrolysis required to produce it, which involves high amounts of electricity with a subsequent high coefficient for both embodied energy and embodied $\mathrm{CO}_{2}$ emissions (Alcorn, 2003; Szalay \& Nebel, 2006). This graph demonstrates how the simple replacement of aluminium influences the initial embodied energy outcome.

The second most embodied energy intensive component is the structural system. This is roughly $30 \%$ of the initial embodied energy for the concrete, timber and timber-plus building (ranging from 3,708 to 4,406 GJ). The trend is drastically different for the steel building $(8,415 \mathrm{GJ})$ where the structural system is almost $50 \%$ of the initial embodied energy. Interior finishes account for roughly $10 \%$ of all cases (ranging from 1,833 to $2,222 \mathrm{GJ}$ ), envelopes account for roughly $7 \%$ (ranging from 688 to 1,246 GJ) and foundations account for $5 \%$ (with an average of $604 \mathrm{GJ}$ ).

Figure 4.5 shows, for the concrete, steel, timber and timber-plus buildings (using the Alcorn database), the total embodied energy of each of the five buildings components. The trend is very similar to that presented in the graph with the results using the $\mathrm{GaBi}$ database, but with more energy involved in each of the components. Again windows and louvers are the most energy intensive building component (10,174 GJ). There is the same energy reduction in the windows and louvers component for the timber-plus building $(1,784 \mathrm{GJ})$. Also in this graph, the steel building structural system $(12,856 \mathrm{GJ})$ is the most energy intensive component of all components in Figure 4.4 and 4.5.

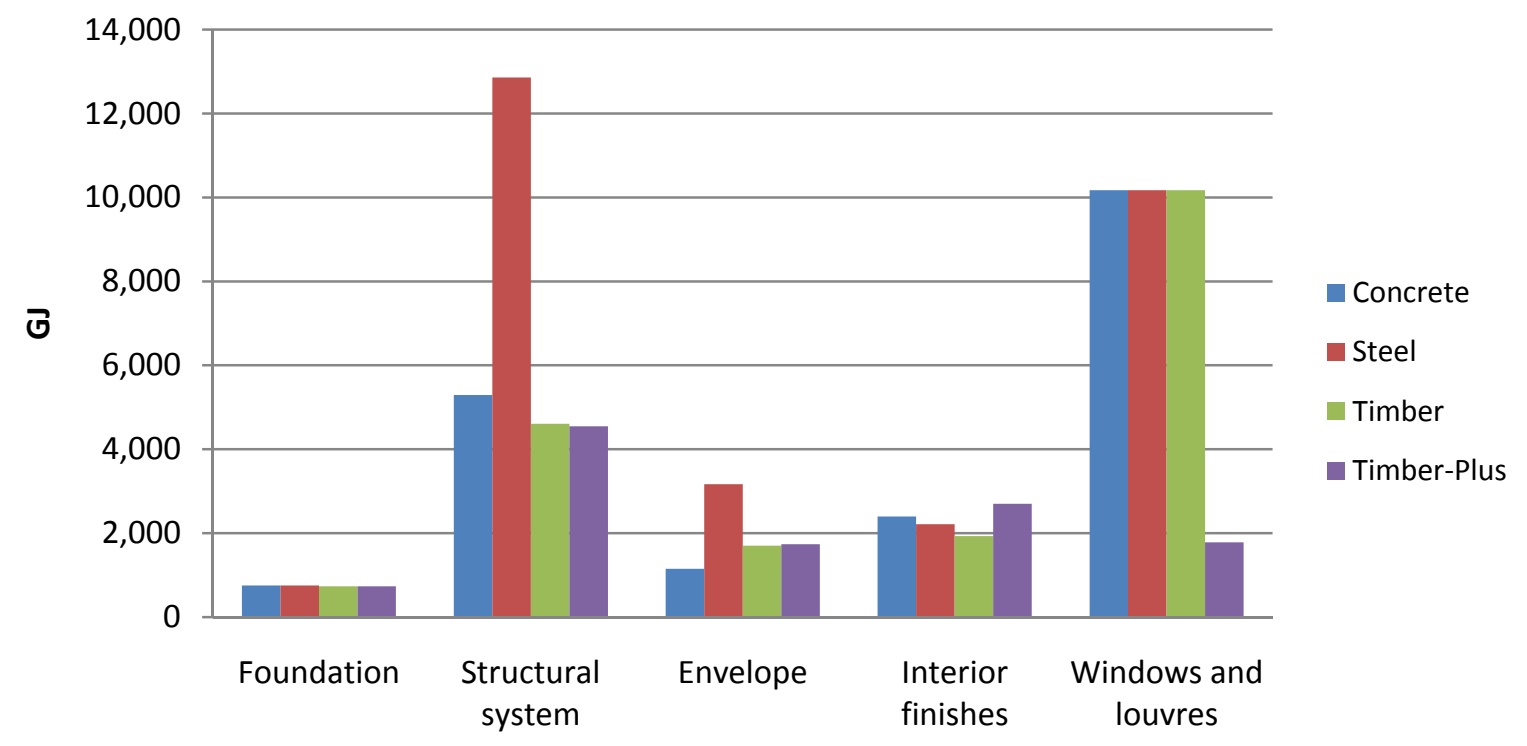

Figure 4-5: Total embodied energy segregated into five major building components for the concrete, steel, timber and timber-plus buildings (using the Alcorn database). 


\subsubsection{Total life-cycle energy consumption}

This section adds the operating energy consumption to the total embodied energy to obtain a total figure. Table 4.9 shows the 60 year life-cycle energy consumption for the concrete, steel, timber and timber-plus buildings. The life-cycle energy consumption in GJ accounts for the building's 60 years of operational energy, the initial embodied energy and the 60 years of recurrent embodied energy. Each building has two results for life-cycle energy use. This is because, for initial and recurrent embodied energy results were produced using both the $\mathrm{GaBi}$ and the Alcorn databases for embodied energy coefficients.

\begin{tabular}{|c|c|c|}
\hline Operational energy & Embodied energy & Life-cycle energy \\
\hline 60 years operations & $\begin{array}{l}\text { Initial embodied energy plus } \\
\text { recurrent embodied energy }\end{array}$ & $\begin{array}{l}\text { Operational energy plus } \\
\text { total embodied energy }\end{array}$ \\
\hline
\end{tabular}

1 Concrete building

\begin{tabular}{|c|c|c|c|c|c|c|}
\hline 64,138 GJ & \multirow[t]{2}{*}{$80 \%$} & \multirow[t]{2}{*}{ Gabi } & 15,765 GJ & \multirow[t]{2}{*}{$20 \%$} & 79,903 GJ & \multirow[t]{2}{*}{$100 \%$} \\
\hline $18.1 \mathrm{GJ} / \mathrm{m}^{2}$ & & & $4.5 \mathrm{GJ} / \mathrm{m}^{2}$ & & $22.6 \mathrm{GJ} / \mathrm{m}^{2}$ & \\
\hline & \multirow[t]{2}{*}{$76 \%$} & \multirow[t]{2}{*}{ Alcorn } & 19,768 GJ & \multirow[t]{2}{*}{$24 \%$} & $83,906 \mathrm{GJ}$ & \multirow[t]{2}{*}{$100 \%$} \\
\hline & & & $5.6 \mathrm{GJ} / \mathrm{m}^{2}$ & & $23.7 \mathrm{GJ} / \mathrm{m}^{2}$ & \\
\hline
\end{tabular}

2 Steel building

\begin{tabular}{|c|c|c|c|c|c|c|}
\hline $65,310 \mathrm{GJ}$ & \multirow[t]{2}{*}{$76 \%$} & \multirow[t]{2}{*}{ Gabi } & 20,457 GJ & \multirow[t]{2}{*}{$24 \%$} & 85,768 GJ & \multirow[t]{2}{*}{$100 \%$} \\
\hline $18.5 \mathrm{GJ} / \mathrm{m}^{2}$ & & & $5.8 \mathrm{GJ} / \mathrm{m}^{2}$ & & $24.3 \mathrm{GJ} / \mathrm{m}^{2}$ & \\
\hline & \multirow[t]{2}{*}{$69 \%$} & \multirow[t]{2}{*}{ Alcorn } & $29,167 \mathrm{GJ}$ & \multirow[t]{2}{*}{$31 \%$} & $94,478 \mathrm{GJ}$ & \multirow[t]{2}{*}{$100 \%$} \\
\hline & & & $8.2 \mathrm{GJ} / \mathrm{m}^{2}$ & & $26.7 \mathrm{GJ} / \mathrm{m}^{2}$ & \\
\hline
\end{tabular}

3 Timber building

\begin{tabular}{|c|c|c|c|c|c|c|}
\hline $67,255 \mathrm{GJ}$ & \multirow[t]{2}{*}{$81 \%$} & \multirow[t]{2}{*}{ Gabi } & $15,900 \mathrm{GJ}$ & \multirow[t]{2}{*}{$19 \%$} & 83,155 GJ & \multirow[t]{2}{*}{$100 \%$} \\
\hline $19.0 \mathrm{GJ} / \mathrm{m}^{2}$ & & & $4.5 \mathrm{GJ} / \mathrm{m}^{2}$ & & $23.5 \mathrm{GJ} / \mathrm{m}^{2}$ & \\
\hline & \multirow[t]{2}{*}{$78 \%$} & \multirow[t]{2}{*}{ Alcorn } & 19,476 GJ & \multirow[t]{2}{*}{$22 \%$} & $86,731 \mathrm{GJ}$ & \multirow[t]{2}{*}{$100 \%$} \\
\hline & & & $5.5 \mathrm{GJ} / \mathrm{m}^{2}$ & & $24.5 \mathrm{GJ} / \mathrm{m}^{2}$ & \\
\hline
\end{tabular}

4 Timber-Plus building

\begin{tabular}{|c|c|c|c|c|c|c|}
\hline 65,824 GJ & \multirow[t]{2}{*}{$88 \%$} & \multirow[t]{2}{*}{ Gabi } & $8,685 \mathrm{GJ}$ & \multirow[t]{2}{*}{$12 \%$} & $74,509 \mathrm{GJ}$ & \multirow[t]{2}{*}{$100 \%$} \\
\hline $18.6 \mathrm{GJ} / \mathrm{m}^{2}$ & & & $2.5 \mathrm{GJ} / \mathrm{m}^{2}$ & & $21.1 \mathrm{GJ} / \mathrm{m}^{2}$ & \\
\hline & \multirow[t]{2}{*}{$85 \%$} & \multirow[t]{2}{*}{ Alcorn } & $11,832 \mathrm{GJ}$ & \multirow[t]{2}{*}{$15 \%$} & $77,656 \mathrm{GJ}$ & \multirow[t]{2}{*}{$100 \%$} \\
\hline & & & $3.3 \mathrm{GJ} / \mathrm{m}^{2}$ & & $22.0 \mathrm{GJ} / \mathrm{m}^{2}$ & \\
\hline
\end{tabular}

Net Usable Area:

$3,536 \mathrm{~m}^{2}$

Table 4.9: Total 60 year life-cycle energy use, including 60 years of operating energy consumption, total embodied energy (initial embodied and recurrent embodied energy) using embodied energy coefficients based on the GaBi and the Alcorn databases.

When using the GaBi database, 60 years of operating energy ranges from $76 \%$ of the total life-cycle energy consumption in the steel building $(65,310 \mathrm{GJ})$ to $89 \%$ in the timber-plus building $(65,824 \mathrm{GJ})$. The initial embodied energy ranges from $9 \%$ of the life-cycle energy consumption in the timber-plus building $(6,938 \mathrm{GJ})$ 
to $21 \%$ in the steel building (17,883 GJ). Finally, recurrent embodied energy accounts for $3 \%$ of the total lifecycle energy consumption in the buildings $(2,315-2,728 \mathrm{GJ})$, except for the timber-plus where recurrent embodied energy accounts for only $2 \%(1,747 \mathrm{GJ})$.

When using the Alcorn database, the trends remains the same. The 60 years of operating energy consumption ranges from $69 \%$ of the total life-cycle energy consumption in the steel building to $85 \%$ in the timber-plus building. The initial embodied energy ranges from $12 \%$ of the life-cycle energy use in the timberplus building $(9,171 \mathrm{GJ})$ to $27 \%$ in the steel building (25,969 GJ). Finally, recurrent embodied energy accounts for $3 \%(2,399-3,198 \mathrm{GJ})$ of the total life-cycle energy use in all cases.

\subsubsection{Ranking of buildings' life-cycle energy use}

When looking at the total life-cycle energy use of the concrete, steel, timber and timber-plus buildings, using both the $\mathrm{GaBi}$ and the Alcorn databases, the trend is the same. The timber-plus building has the lowest lifecycle energy consumption with a total of $74,329 \mathrm{GJ}$ when using the GaBi database and 77,327 GJ when the Alcorn database is used. The concrete building follows the timber-plus with 5,394 GJ more total energy consumption than the timber-plus building when using the GaBi database and 6,250 GJ when using the Alcorn database. Next is the timber building with 8,646 GJ more life-cycle energy consumption when the GaBi database is used and 9,075 GJ higher when the Alcorn database is used. The highest life-cycle energy consumption is for the steel building, consuming 11,256 GJ more energy than the timber-plus building when the $\mathrm{GaBi}$ database is used and $16,822 \mathrm{GJ}$ more when the Alcorn database is used.

Figure 4.6 shows, for the concrete, steel, timber and timber-plus buildings, the life-cycle operating energy consumption, initial embodied energy, recurrent embodied energy and finally the total life-cycle energy consumption. Initial and recurrent energy in this graph was calculated using the GaBi database and operating energy was calculated by energy performance simulations using DesignBuilder software (DesignBuilder Software, 2008).

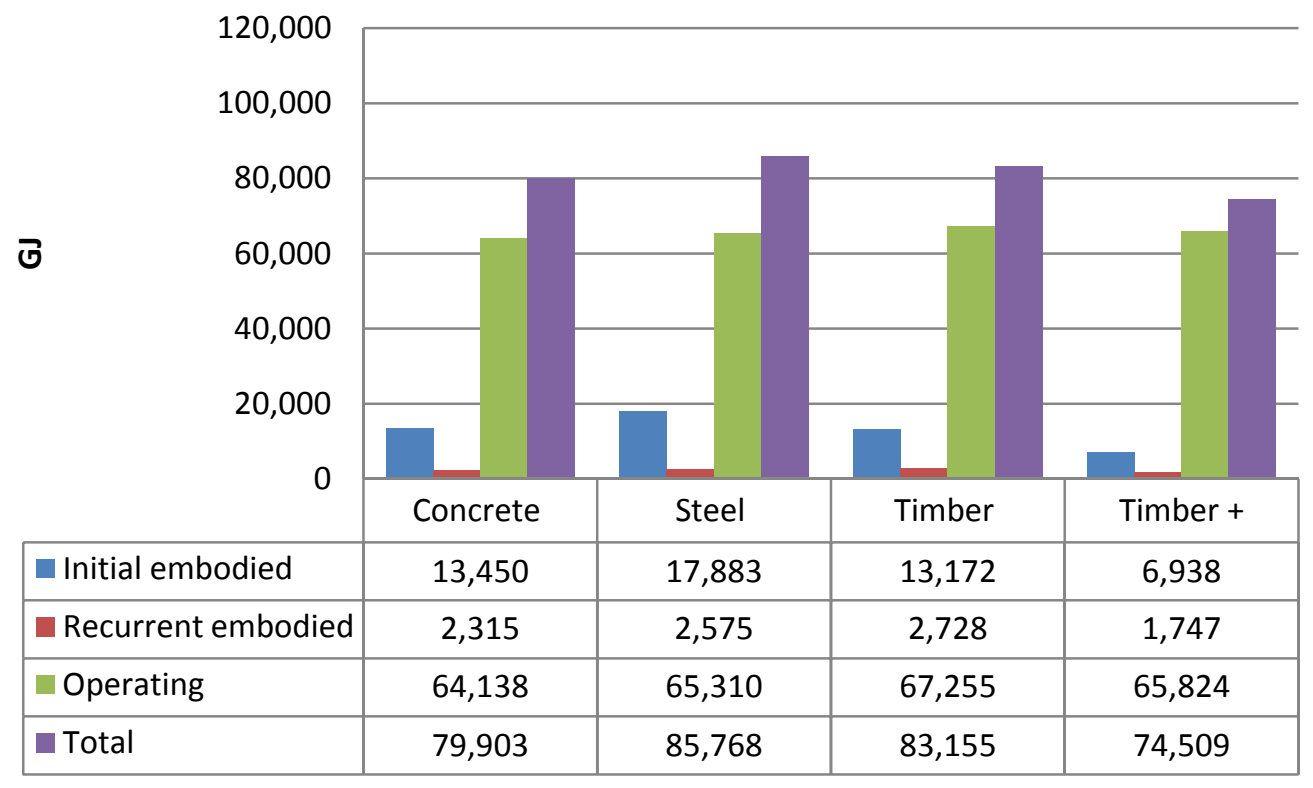

Figure 4-6: Total life-cycle energy consumption; results produced using the GaBi database. 
Operating energy consumption averages $82 \%$ of the total life-cycle energy consumption for all buildings. Initial and recurrent embodied energy added together account for the remaining $18 \%$ of the life-cycle energy use. There is a total difference between the lowest life-cycle energy consumption (timber-plus building) and the highest (steel building) of $11,439 \mathrm{GJ}$ and this represents a $15 \%$ energy increment in total in the life-cycle energy consumption of the steel building. The difference between the timber-plus and the concrete building (next lowest life-cycle energy consumption after timber-plus building) is 5,394 GJ, representing a $7 \%$ difference in life-cycle energy consumption; between the concrete and timber building it is 3,252 GJ, representing a 4\% difference; and between the timber and steel building the difference is $2,613 \mathrm{GJ}$, representing $4 \%$ difference.

Figure 4.7 shows, for the concrete, steel, timber and timber-plus buildings, the operating energy consumption, initial embodied energy, recurrent embodied energy and finally the total life-cycle energy consumption. Initial and recurrent embodied energy in this graph were produced using the Alcorn database.

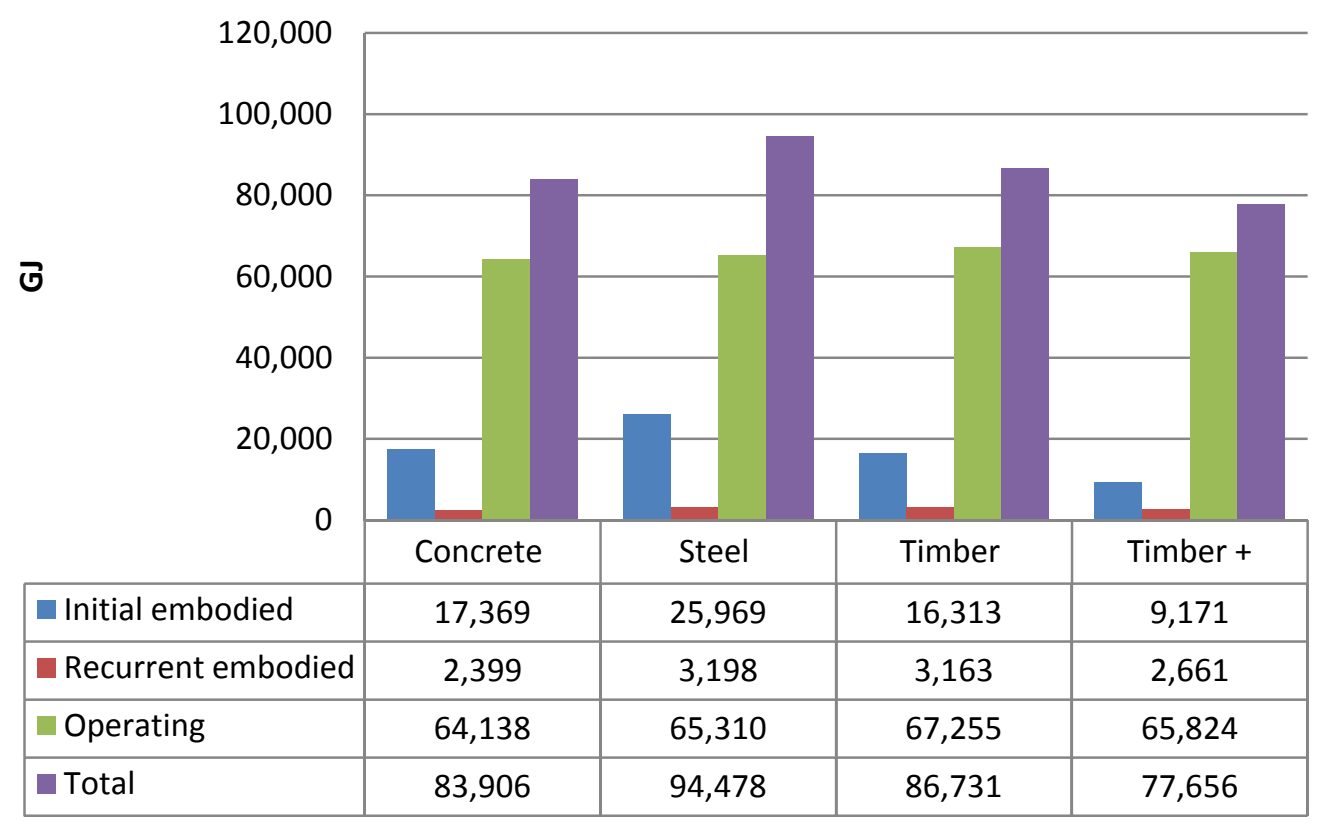

Figure 4-7: Total life-cycle energy consumption using the Alcorn database.

Operating energy in this graph averages $77 \%$ of the total life-cycle energy use for all buildings. Initial and recurrent embodied energy together account for the remaining $23 \%$ of the life-cycle energy use. There is a difference between the lowest total life-cycle energy consumption (timber-plus building) and the highest (steel building) of $17,150 \mathrm{GJ}$ and this represents a $22 \%$ energy increment in the steel building's life-cycle energy use. The difference between the timber-plus and the concrete building (next lowest life-cycle energy consumption after timber-plus building) is $6,250 \mathrm{GJ}$, representing a $9 \%$ difference in life-cycle energy consumption; between the concrete and timber building the difference is $2,825 \mathrm{GJ}$, representing a $3 \%$ difference; and between the timber and steel building the difference is $7,747 \mathrm{GJ}$, representing a $10 \%$ difference.

Depending on the choice of the database used for calculating of the initial embodied energy and the recurrent embodied energy change, the proportions of the components of the total life-cycle energy use of 


\section{Results}

the buildings change significantly. When the GaBi database is used, total embodied energy is approximately a fifth of the total life-cycle energy use and it is equivalent to 14 years of operating energy. When the Alcorn database is used, total embodied energy is approximately a quarter of the total life-cycle energy use and is equivalent to 18 years of operating energy. 


\subsection{Life-cycle $\mathrm{CO}_{2}$ emissions}

As explained in the introduction to Chapter 4, this chapter is divided into two main sections: 4.1, Life-cycle energy consumption and 4.2, Life-cycle $\mathrm{CO}_{2}$ emissions. The following section will present the results produced for operating $\mathrm{CO}_{2}$ emissions, embodied $\mathrm{CO}_{2}$ emissions and finally the life-cycle $\mathrm{CO}_{2}$ emissions in a similar sequence to Section 4.1.

Operational $\mathrm{CO}_{2}$ emissions are calculated directly from the operational energy figures, using relevant coefficients of $\mathrm{CO}_{2}$ emissions for electricity and LPG introduced in Chapter 3, Section 3.5.2.1 (LCA scope in this research). For embodied $\mathrm{CO}_{2}$ emissions, the parallel sets of results produced using the $\mathrm{GaBi}$ and the Alcorn database will be retained.

\subsubsection{Operating $\mathrm{CO}_{2}$ emissions}

As it was explained in Chapter 3, Section 3.3.3 (Energy sources and $\mathrm{CO}_{2}$ factors), specific New Zealand data was used for $\mathrm{CO}_{2}$ emissions of the energy sources. The $\mathrm{CO}_{2}$ factor for electricity and LPG was taken from the "Emissions calculator" of the New Zealand Business Council for Sustainable Development (NZBCSD).

The data in this section is broken into $\mathrm{CO}_{2}$ emissions due to electricity and gas (LPG), and the total final consumption is divided by the gross floor area (measured inside the external walls). The $\mathrm{CO}_{2}$ factors provided by the NZBCSD were multiplied by the energy values produced in the operating energy simulation process. For electricity the factor used was 0.000450 tonnes of $\mathrm{CO}_{2}$ per $\mathrm{kWh}$ (New Zealand Business Council for Sustainable Development, 2008). For gas, this was replaced by LPG and the factor of this is suggested as 0.0604 tones of $\mathrm{CO}_{2}$ emitted by GJ of energy produced. The $\mathrm{CO}_{2}$ emission in the transport of LPG is not accounted for in that factor (New Zealand Business Council for Sustainable Development, 2008).

Table 4.10 shows, for the concrete, steel, timber and timber-plus building, the annual operating $\mathrm{CO}_{2}$ emissions (tonnes/yr) resulting from the annual operating energy use. As with operating energy consumption, annual operating $\mathrm{CO}_{2}$ emissions are fairly similar for all four buildings. The lowest emission is for the concrete building emitting 121 tonnes of $\mathrm{CO}_{2} / \mathrm{yr}$. The steel building emits 2 more tonnes of $\mathrm{CO}_{2}(2 \%)$ than the concrete building; the timber-plus building emits 1 more tonne of $\mathrm{CO}_{2}(0.7 \%)$ than the steel building; and the timber building emits 4 more tonnes of $\mathrm{CO}_{2}(3 \%)$ than the timber-plus building.

The difference in the total operating $\mathrm{CO}_{2}$ emissions between the lowest and the highest emissions (between the concrete and the timber building) amounts to a total of 7 tonnes of $\mathrm{CO}_{2} / \mathrm{yr}$ and represents a $6 \%$ difference. 
Energy in operations

Total Energy used
$\mathrm{CO}_{\mathbf{2}}$ emissions in operations

Total $\mathrm{CO}_{2}$ emitted

Tonnes / year

GJ Annual differences

$\% \quad$ Tonnes of $\mathrm{CO}_{2}$

1 Concrete building

\begin{tabular}{|l|c|c|}
\hline Total electricity & $868 \mathrm{GJ} / \mathrm{yr}$ & 109 Tonnes $/ \mathrm{yr}$ \\
\hline Total Gas & $201 \mathrm{GJ} / \mathrm{yr}$ & 12 Tonnes $/ \mathrm{yr}$ \\
\hline Total energy use: & $1,069 \mathrm{GJ} / \mathrm{yr}$ & 121 Tonnes $/ \mathrm{yr}$ \\
\hline Total energy use $/ \mathrm{m}^{2}:$ & $0.30 \mathrm{GJ} / \mathrm{m}^{2} . \mathrm{yr}$ \\
& & 0.034 Tonnes $/ \mathrm{m}^{2} . \mathrm{yr}$ \\
\hline
\end{tabular}

0

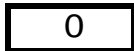

2 Steel building

\begin{tabular}{|l|c|c|}
\hline Total electricity & $886 \mathrm{GJ} / \mathrm{yr}$ & 111 Tonnes $/ \mathrm{yr}$ \\
\hline Total Gas & $203 \mathrm{GJ} / \mathrm{yr}$ & 12 Tonnes $/ \mathrm{yr}$ \\
\hline Total energy use: & $1,089 \mathrm{GJ} / \mathrm{yr}$ & 123 Tonnes $/ \mathrm{yr}$ \\
\hline Total energy use $/ \mathrm{m}^{2}:$ & $0.31 \mathrm{GJ} / \mathrm{m}^{2} . \mathrm{yr}$ & 0.035 Tonnes $/ \mathrm{m}^{2} . \mathrm{yr}$ \\
\hline
\end{tabular}

2

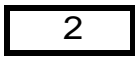

3 Timber building

\begin{tabular}{|l|c|}
\hline Total electricity & $927 \mathrm{GJ} / \mathrm{yr}$ \\
\hline Total Gas & $194 \mathrm{GJ} / \mathrm{yr}$ \\
\hline Total energy use: & $1,121 \mathrm{GJ} / \mathrm{yr}$ \\
\hline Total energy use $/ \mathrm{m}^{2}:$ & $0.32 \mathrm{GJ} / \mathrm{m}^{2} . \mathrm{yr}$ \\
\hline
\end{tabular}

\begin{tabular}{|c|}
\hline 116 Tonnes $/ \mathrm{yr}$ \\
\hline 12 Tonnes/yr \\
\hline 128 Tonnes $/ \mathrm{yr}$ \\
\hline 0.036 Tonnes $/ \mathrm{m}^{2} . \mathrm{yr}$ \\
\hline
\end{tabular}

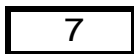

\section{Timber-Plus building}

\begin{tabular}{|l|c|}
\hline Total electricity & $890 \mathrm{GJ} / \mathrm{yr}$ \\
\hline Total Gas & $207 \mathrm{GJ} / \mathrm{yr}$ \\
\hline Total energy use: & $1,097 \mathrm{GJ} / \mathrm{yr}$ \\
\hline Total energy use $/ \mathrm{m}^{2}:$ & $0.31 \mathrm{GJ} / \mathrm{m}^{2} . \mathrm{yr}$ \\
\hline
\end{tabular}

\begin{tabular}{|c|}
\hline 111 Tonnes $/ \mathrm{yr}$ \\
\hline 12 Tonnes $/ \mathrm{yr}$ \\
\hline 124 Tonnes $/ \mathrm{yr}$ \\
\hline 0.035 Tonnes $/ \mathrm{m}^{2} . \mathrm{yr}$ \\
\hline
\end{tabular}

Net Usable Area:

$3,536 \mathrm{~m}^{2}$

Table 4.10: Annual energy use and $\mathrm{CO}_{2}$ emissions in operations

The timber-plus and the steel buildings have similar operating $\mathrm{CO}_{2}$ emissions. The steel building emits only 1 less tonne of $\mathrm{CO}_{2} / \mathrm{yr}$ than the timber-plus building. When operating energy is divided by the building's Net Usable Area, the differences between buildings become negligible. The concrete has the lowest value $(0,034$ tonnes of $\left.\mathrm{CO}_{2} / \mathrm{m}^{2} . \mathrm{yr}\right)$, then the steel and timber-plus buildings $\left(0.035\right.$ tonnes of $\left.\mathrm{CO}_{2} / \mathrm{m}^{2} . \mathrm{yr}\right)$ and finally the timber building $\left(0.36\right.$ tonnes of $\left.\mathrm{CO}_{2} / \mathrm{m}^{2} . \mathrm{yr}\right)$.

Electricity accounts for roughly $85 \%$ of the total energy consumed, with gas accounting for the remaining $15 \%$. When looking at $\mathrm{CO}_{2}$ emissions, electricity accounts for $90 \%$ and gas (LPG) for the remaining $10 \%$. 


\subsubsection{Operating $\mathrm{CO}_{2}$ emissions segregated into end-uses}

Table C.2 (Appendix C.3) shows, for the concrete, steel, timber and timber-plus buildings, the annual operating $\mathrm{CO}_{2}$ emissions broken into five end-uses (see Section 4.1.1.2 (operating energy segregated in end-uses)).

Similar to the results in operating energy, $\mathrm{CO}_{2}$ emissions from cooling account for the main variation between each of the four buildings. There is a 1 tonne of $\mathrm{CO}_{2}$ increase for heating in the timber-plus building (10 $\mathrm{CO}_{2}$ tonnes/yr) compared with the concrete, steel and timber buildings which create the same amount of emissions $\left(9 \mathrm{CO}_{2}\right.$ tonnes/yr) for heating.

The highest emissions are for lighting, being $54 \mathrm{CO}_{2}$ tonnes/yr for all buildings. Room electricity accounts for the second largest $\mathrm{CO}_{2}$ emissions $\left(34 \mathrm{CO}_{2}\right.$ tonnes/yr) in three of the buildings, while there is a 1 tonne of $\mathrm{CO}_{2}$ reduction in the room electricity of the steel building. Cooling $\mathrm{CO}_{2}$ emissions range from $14 \mathrm{CO}_{2}$ tonnes/yr in the concrete building to $21 \mathrm{CO}_{2}$ tonnes/yr in the timber building. As with operating energy consumption, the operating $\mathrm{CO}_{2}$ emissions are not radically different between the concrete, steel, timber and timber-plus buildings. The largest difference is $7 \mathrm{CO}_{2}$ tonnes/yr, but the average difference between buildings is $3 \mathrm{CO}_{2}$ tonnes/yr. Differences in emissions are mainly due to cooling performance; while heating and room electricity account for less energy consumption.

Figure 4.8 shows, for the concrete, steel, timber and timber-plus buildings, the $\mathrm{CO}_{2}$ emissions of the five end-uses.

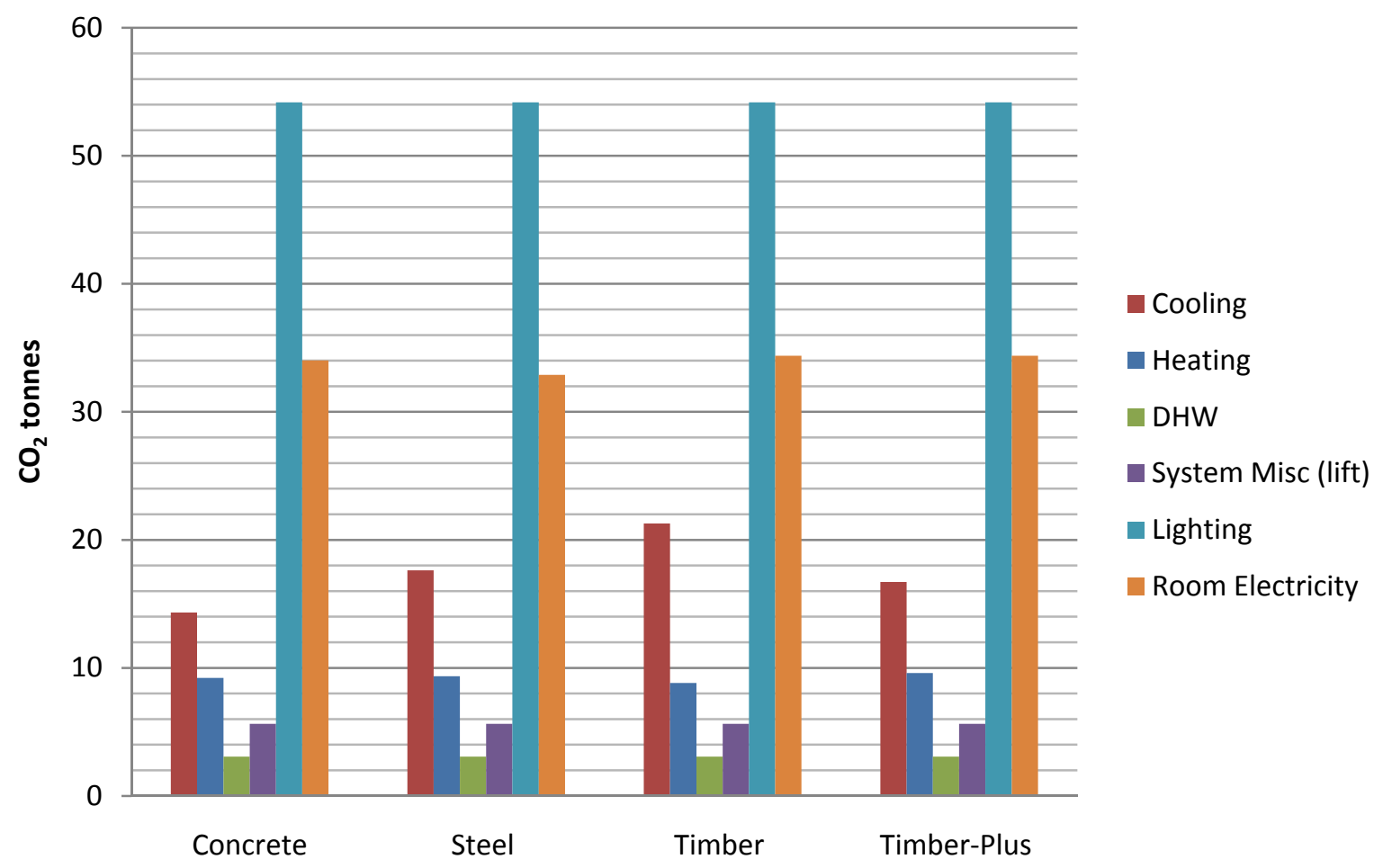

Figure 4-8: Annual operating $\mathrm{CO}_{2}$ emissions divided into end-uses for the concrete, steel, timber and timber-plus buildings. 
As said before, $\mathrm{CO}_{2}$ emissions from lighting (54 tonnes of $\mathrm{CO}_{2} / \mathrm{yr}$ ) have by far the highest end-uses $\mathrm{CO}_{2}$ emissions averaging $44 \%$ of the operating $\mathrm{CO}_{2}$ emissions. Room electricity (34 tonnes of $\mathrm{CO}_{2} / \mathrm{yr}$ ) accounts for an average of $28 \%$ of the operating $\mathrm{CO}_{2}$ emissions, cooling ( 17.5 tonnes of $\mathrm{CO}_{2} / \mathrm{yr}$ ) an average of $15 \%$, heating ( 9 tonnes of $\mathrm{CO}_{2} / \mathrm{yr}$ ) an average of $8 \%$, system miscellaneous ( 6 tonnes of $\mathrm{CO}_{2} / \mathrm{yr}$ ) an average of $5 \%$ and finally DHW (3 tonnes of $\mathrm{CO}_{2} / \mathrm{yr}$ ) with an average of $3 \%$.

When looking at energy consumption, cooling and heating represent $13 \%$ and $14 \%$ of the operating energy respectively. When looking at $\mathrm{CO}_{2}$ emissions, cooling represents $14 \%$ and heating only $7 \%$ of the operating $\mathrm{CO}_{2}$ emissions. This difference in operating energy when translated into $\mathrm{CO}_{2}$ emissions, is because cooling uses electricity and heating uses LPG. The $\mathrm{CO}_{2}$ factor for LPG is lower than the $\mathrm{CO}_{2}$ factor for electricity. Due to this difference, heating uses a similar amount of energy to cooling, but is much lower in $\mathrm{CO}_{2}$ emissions. 


\subsubsection{Life-cycle operating $\mathrm{CO}_{2}$ emissions}

Table 4.11 shows the annual operating $\mathrm{CO}_{2}$ emissions multiplied by a 60 year life-cycle for the four buildings. The life-cycle operating energy consumption is presented in $\mathrm{CO}_{2}$ tonnes and the total $\mathrm{CO}_{2}$ emissions are then divided by the buildings' gross floor area (measured inside external walls).

Total yearly $\mathrm{CO}_{2}$ emitted in operations

\section{$\mathrm{CO}_{2}$ Tonnes / year}

1 Concrete building

\begin{tabular}{|l|c|}
\hline Total electricity & 109 Tonnes/year \\
\hline Total Gas & 12 Tonnes/year \\
\hline Total $\mathrm{CO}_{2}$ emitted & 121 Tonnes/year \\
\hline Total $\mathrm{CO}_{2}$ emitted $/ \mathrm{m}^{2}$ & 0.03 Tonnes $/ \mathrm{m}^{2}$.year \\
\hline
\end{tabular}

2 Steel building

\begin{tabular}{|l|c|}
\hline Total electricity & 111 Tonnes/year \\
\hline Total Gas & 12 Tonnes/year \\
\hline Total $\mathrm{CO}_{2}$ emitted & 123 Tonnes/year \\
\hline Total $\mathrm{CO}_{2}$ emitted $/ \mathrm{m}^{2}$ & 0.03 Tonnes $/ \mathrm{m}^{2}$.year \\
\hline
\end{tabular}

3 Timber building

\begin{tabular}{|l|c|}
\hline Total electricity & 116 Tonnes/year \\
\hline Total Gas & 12 Tonnes/year \\
\hline Total $\mathrm{CO}_{2}$ emitted & 128 Tonnes/year \\
\hline Total $\mathrm{CO}_{2}$ emitted $/ \mathrm{m}^{2}$ & 0.04 Tonnes $/ \mathrm{m}^{2}$.year \\
\hline
\end{tabular}

4 Timber-Plus building

\begin{tabular}{|l|c|}
\hline Total electricity & 111 Tonnes/year \\
\hline Total Gas & 12 Tonnes/year \\
\hline Total $\mathrm{CO}_{2}$ emitted & 124 Tonnes/year \\
\hline Total $\mathrm{CO}_{2}$ emitted $/ \mathrm{m}^{2}$ & 0.03 Tonnes $/ \mathrm{m}^{2}$.year \\
\hline
\end{tabular}

Net Usable Area:
Total life cycle (60 years)

$$
\mathrm{CO}_{2} \text { tonnes }
$$

\begin{tabular}{|c|}
\hline 6,512 Tonnes \\
\hline 728 Tonnes \\
\hline 7,239 Tonnes \\
\hline 2.05 Tonnes $/ \mathrm{m}^{2}$ \\
\hline
\end{tabular}

\begin{tabular}{|c|}
\hline 6,642 Tonnes \\
\hline 735 Tonnes \\
\hline 7,377 Tonnes \\
\hline 2.09 Tonnes $/ \mathrm{m}^{2}$ \\
\hline
\end{tabular}

\begin{tabular}{|c|}
\hline 6,951 Tonnes \\
\hline 704 Tonnes \\
\hline 7,654 Tonnes \\
\hline 2.16 Tonnes $/ \mathrm{m}^{2}$ \\
\hline
\end{tabular}

\begin{tabular}{|c|}
\hline 6,676 Tonnes \\
\hline 750 Tonnes \\
\hline 7,426 Tonnes \\
\hline 2.10 Tonnes $/ \mathrm{m}^{2}$ \\
\hline
\end{tabular}

$3,536 \mathrm{~m}^{2}$

Table 4.11: Annual and life-cycle operating $\mathrm{CO}_{2}$ emissions

As can be seen, the pattern is the same as in life-cycle operating energy use (see Table 4.1). The concrete building has the lowest life-cycle operating $\mathrm{CO}_{2}$ emissions. Compared with the concrete building, the second lowest life-cycle operating $\mathrm{CO}_{2}$ emissions is the steel building which is higher by $1.9 \%$ (138 tonnes of $\mathrm{CO}_{2} / \mathrm{yr}$ ); third is the timber-plus building which is $2.6 \%$ (187 tonnes of $\mathrm{CO}_{2} / \mathrm{yr}$ ) higher than the concrete building and finally the timber building which is $5.7 \%$ (415 tonnes of $\mathrm{CO}_{2} / \mathrm{yr}$ ) higher than the life-cycle operating $\mathrm{CO}_{2}$ emissions of the concrete building. When the buildings' life-cycle operating emissions are compared to each other, there is $1.9 \%$ (138 tonnes of $\mathrm{CO}_{2} / \mathrm{yr}$ ) more operating $\mathrm{CO}_{2}$ emissions in the steel building compared with the concrete building, $0.7 \%$ (49 tonnes of $\mathrm{CO}_{2} / \mathrm{yr}$ ) more operating $\mathrm{CO}_{2}$ emissions in the timber-plus building compared with the steel building and finally $3.1 \%$ (228 tonnes of $\mathrm{CO}_{2} / \mathrm{yr}$ ) more operating $\mathrm{CO}_{2}$ emissions in the timber building compared with the timber plus-building.

There is a small difference in life-cycle operating $\mathrm{CO}_{2}$ emissions between the steel and the timber-plus buildings: the timber-plus building has $0.7 \%$ more life-cycle operating $\mathrm{CO}_{2}$ emissions than the steel building; 
this is $49 \mathrm{CO}_{2}$ tonnes of difference after 60 years of operations. The difference in the 60 year life-cycle operating $\mathrm{CO}_{2}$ emissions between the concrete and timber building is 415 tonnes of $\mathrm{CO}_{2}$.

\subsubsection{Embodied $\mathrm{CO}_{2}$ emissions}

As explained in Section 4.1.2 (Embodied energy), this research presents the data of initial and recurrent embodied energy and initial and recurrent $\mathrm{CO}_{2}$ emissions segregated between the results produced using the Alcorn and the GaBi databases. Table 4.12 shows for the concrete, steel, timber and timber-plus buildings, the total embodied $\mathrm{CO}_{2}$ resulting from the addition of the initial embodied $\mathrm{CO}_{2}$ and the 60 year recurrent embodied $\mathrm{CO}_{2}$.

$\begin{array}{llll}\begin{array}{l}\text { Initial } \\ \text { embodied } \mathrm{CO}_{2}\end{array} & \begin{array}{l}\text { Recurrent } \\ \text { embodied } \mathrm{CO}_{2}\end{array} & \begin{array}{l}\text { Total } \\ \text { embodied } \mathrm{CO}_{2}\end{array} & \begin{array}{l}\text { Alcorn as } \\ \text { \% of } \mathrm{GaBi}\end{array} \\ {_{2} \text { tonnes }} } & \mathrm{CO}_{2} \text { tonnes } & \frac{\mathrm{CO}_{2} \text { tonnes }}{2} & \end{array}$

\section{Concrete building}

\begin{tabular}{|c|c|c|c|c|c|c|c|}
\hline \multirow[t]{2}{*}{ GaBi } & 1,274 Tonnes & \multirow[t]{2}{*}{$88 \%$} & 177 Tonnes & \multirow[t]{2}{*}{$12 \%$} & 1,451 Tonnes & \multirow{2}{*}{\multicolumn{2}{|c|}{$100 \%$}} \\
\hline & $0.36 \mathrm{t} / \mathrm{m}^{2}$ & & $0.05 \mathrm{t} / \mathrm{m}^{2}$ & & $0.41 \mathrm{t} / \mathrm{m}^{2}$ & & \\
\hline \multirow[t]{2}{*}{ Alcorn } & 1,129 Tonnes & \multirow[t]{2}{*}{$91 \%$} & 116 Tonnes & \multirow[t]{2}{*}{$9 \%$} & 1,245 Tonnes & \multirow[t]{2}{*}{$100 \%$} & \multirow[t]{2}{*}{$86 \%$} \\
\hline & $0.32 \mathrm{t} / \mathrm{m}^{2}$ & & $0.03 \mathrm{t} / \mathrm{m}^{2}$ & & $0.35 \mathrm{t} / \mathrm{m}^{2}$ & & \\
\hline
\end{tabular}

2 Steel building

\begin{tabular}{|c|c|c|c|c|c|c|c|}
\hline \multirow[t]{2}{*}{ GaBi } & 1,525 Tonnes & \multirow[t]{2}{*}{$91 \%$} & 149 Tonnes & \multirow[t]{2}{*}{$9 \%$} & 1,674 Tonnes & \multirow{2}{*}{\multicolumn{2}{|c|}{$100 \%$}} \\
\hline & $0.4 \mathrm{t} / \mathrm{m}^{2}$ & & $0.04 \mathrm{t} / \mathrm{m}^{2}$ & & $0.47 \mathrm{t} / \mathrm{m}^{2}$ & & \\
\hline \multirow[t]{2}{*}{ Alcorn } & 1,325 Tonnes & \multirow[t]{2}{*}{$89 \%$} & 166 Tonnes & \multirow[t]{2}{*}{$11 \%$} & 1,491 Tonnes & \multirow[t]{2}{*}{$100 \%$} & \multirow[t]{2}{*}{$89 \%$} \\
\hline & $0.37 \mathrm{t} / \mathrm{m}^{2}$ & & $0.05 \mathrm{t} / \mathrm{m}^{2}$ & & $0.42 \mathrm{t} / \mathrm{m}^{2}$ & & \\
\hline
\end{tabular}

\section{Timber building}

\begin{tabular}{|c|c|c|c|c|c|c|c|}
\hline \multirow[t]{2}{*}{ GaBi } & 1,308 Tonnes & \multirow[t]{2}{*}{$86 \%$} & 220 Tonnes & \multirow[t]{2}{*}{$14 \%$} & 1,528 Tonnes & \multirow{2}{*}{\multicolumn{2}{|c|}{$100 \%$}} \\
\hline & $0.37 \mathrm{t} / \mathrm{m}^{2}$ & & $0.06 \mathrm{t} / \mathrm{m}^{2}$ & & $0.43 \mathrm{t} / \mathrm{m}^{2}$ & & \\
\hline \multirow[t]{2}{*}{ Alcorn } & 163 Tonnes & \multirow[t]{2}{*}{$67 \%$} & 82 Tonnes & \multirow[t]{2}{*}{$33 \%$} & 245 Tonnes & \multirow[t]{2}{*}{$100 \%$} & \multirow[t]{2}{*}{$16 \%$} \\
\hline & $0.05 \mathrm{t} / \mathrm{m}^{2}$ & & $0.02 \mathrm{t} / \mathrm{m}^{2}$ & & $0.07 \mathrm{t} / \mathrm{m}^{2}$ & & \\
\hline
\end{tabular}

4 Timber-Plus building

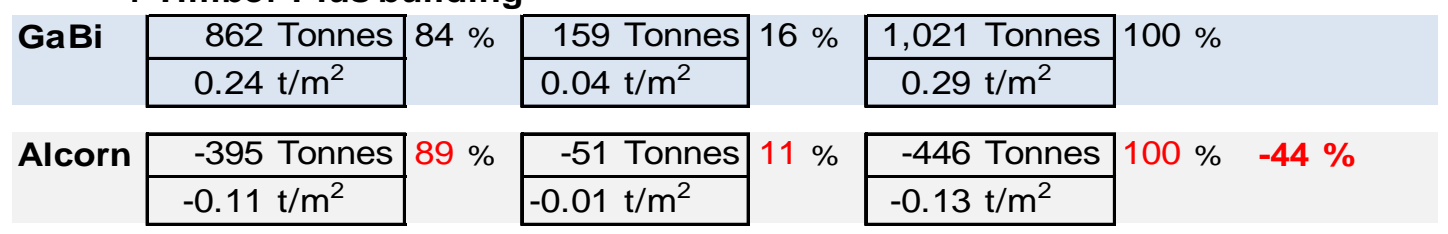

Net Usable Area: $3,536 \mathrm{~m}^{2}$

Table 4.12: Total embodied $\mathrm{CO}_{2}$ emissions segregated into initial and recurrent embodied $\mathrm{CO}_{2}$ emissions using data for embodied $\mathrm{CO}_{2}$ from two different sources: the $\mathrm{GaBi}$ and the Alcorn (2003) databases.

As explained in Section 4.1.2, two different methods were applied to calculate initial and recurrent embodied $\mathrm{CO}_{2}$.for the four buildings in this thesis. Using the schedule of materials produced by the QS, the first total embodied $\mathrm{CO}_{2}$ emissions calculation was done using the GaBi professional LCA tool. The second 
calculation was made by applying the sets of embodied $\mathrm{CO}_{2}$ coefficients developed in New Zealand by Andrew Alcorn (Alcorn, 2003; Nebel \& Love, 2008). In broad terms, GaBi uses average German industry data while Alcorn uses New Zealand specific data (Zsuzsa \& Nebel, 2006).

Figure 4.9 shows, for the concrete, steel, timber and timber-plus buildings, the initial and recurrent embodied $\mathrm{CO}_{2}$ placed together in a single column. Each building's total embodied $\mathrm{CO}_{2}$ is presented using the two different databases mentioned before.

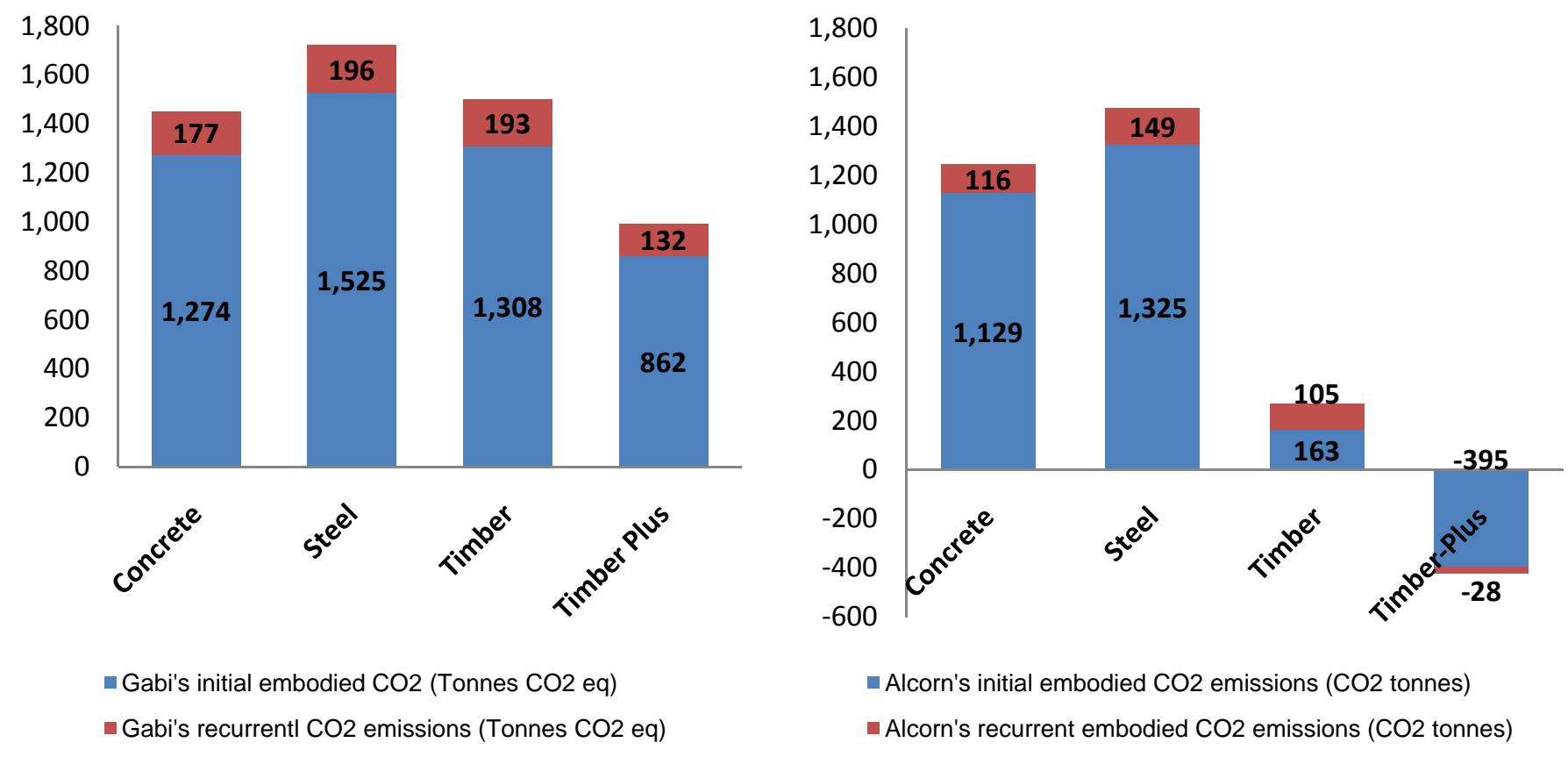

Figure 4-9: Initial and recurrent embodied $\mathrm{CO}_{2}$ emissions produced in separated graphs using the GaBi and Alcorn databases.

There are significant differences between the embodied $\mathrm{CO}_{2}$ results based on the two sets of coefficients. While with embodied energy the Alcorn results averaged $32 \%$ higher than the $\mathrm{GaBi}$, with embodied $\mathrm{CO}_{2}$ the Alcorn results averaged 62\% lower than the GaBi.

- For the concrete building Alcorn is $14 \%$ lower than GaBi.

- For the steel building Alcorn is $11 \%$ lower than GaBi.

- For the timber building Alcorn is $84 \%$ lower than GaBi.

- For the timber-plus building Alcorn is $144 \%$ lower than GaBi.

When looking at the total embodied $\mathrm{CO}_{2}$ emissions, the pattern of the results differs largely between the those produced using the $\mathrm{GaBi}$ database and those produced using the Alcorn database. There are some differences between the concrete and the steel buildings but when comparing the timber and timber-plus buildings differences became far more apparent. This difference is mainly due to the different methodologies that the two sets of coefficients use regarding $\mathrm{CO}_{2}$ sequestration of timber materials. In other words, Figure 4.9 represents two different ways of calculating embodied $\mathrm{CO}_{2}$ in timber products. 
Timber is not only used in the timber and timber-plus buildings; interior and exterior light-weight walls in the concrete buildings are framed in timber stud as well. There is no timber in the steel building. Timber components, when using $\mathrm{GaBi}$, add embodied $\mathrm{CO}_{2}$ to the building while when using Alcorn, timber components offset $\mathrm{CO}_{2}$ emitted by other non-timber components used in the building. Due to $\mathrm{CO}_{2}$ offsetting (when the Alcorn database is used), there is low total embodied $\mathrm{CO}_{2}$ in the timber building and a negative total embodied $\mathrm{CO}_{2}$ in the timber-plus building.

This different approach is particularly important in this thesis. As was explained in a research project undertaken by BRANZ - Timber in Government buildings: "Currently there is no international standardised methodology for dealing with storage of carbon (carbon sequestration) in timber for longer life products such as furniture and buildings" (Page, 2006). The same study argues that due to the lack of an international protocol on the validation and calculation of carbon storage, it is normally ignored.

By showing results produced using the two databases (Alcorn and $\mathrm{GaBi}$ ) this research shows the difference in the outcome produced and, more importantly, what the impact of timber $\mathrm{CO}_{2}$ sequestration is on the lifecycle $\mathrm{CO}_{2}$ emissions of each of the four buildings. $\mathrm{CO}_{2}$ sequestration and storage in timber products has normally been neglected in research. Section 4.2.2 will determine whether there is any overall environmental advantage in the accounting of $\mathrm{CO}_{2}$ storage of buildings components used in buildings.

\subsubsection{Ranking of buildings' total embodied $\mathrm{CO}_{2}$}

For results produced using the $\mathrm{GaBi}$ and the Alcorn databases, initial embodied $\mathrm{CO}_{2}$ emissions represent $87 \%$ and $84 \%$ of the total embodied $\mathrm{CO}_{2}$ emissions respectively. When looking at recurrent embodied $\mathrm{CO}_{2}$ emissions, in $\mathrm{GaBi}$ this accounts for $13 \%$ and in Alcorn for $16 \%$ of the total embodied $\mathrm{CO}_{2}$ emissions.

For buildings' total embodied $\mathrm{CO}_{2}$ emissions calculated using the $\mathrm{GaBi}$ database, the timber-plus building has the lowest total embodied $\mathrm{CO}_{2}\left(1,021 \mathrm{CO}_{2}\right.$ tonnes), followed by the concrete building which is $430 \mathrm{CO}_{2}$ tonnes larger. In the third place, at $507 \mathrm{CO}_{2}$ larger, is the timber building and finally the steel building at 654 $\mathrm{CO}_{2}$ tonnes higher. When looking at the results calculated using the Alcorn database, the trend radically changes. The lowest total embodied $\mathrm{CO}_{2}$ is also the timber-plus building with $-446 \mathrm{CO}_{2}$ tonnes. The timber building is next at $691 \mathrm{CO}_{2}$ tones higher, third is the concrete building, which is $1690 \mathrm{CO}_{2}$ tonnes higher than the timber-plus building, and like in the $\mathrm{GaBi}$ calculation, the highest total embodied $\mathrm{CO}_{2}$ is in the steel building, at $1937 \mathrm{CO}_{2}$ tonnes higher.

\subsubsection{The total embodied $\mathrm{CO}_{2}$ emissions of building components}

This section analyses the buildings' total embodied $\mathrm{CO}_{2}$ emissions segregated into building components. Components in Figure 4.10 and 4.11 were introduced in Section 4.1.2.2. There are five building components: foundations, structural system, envelope, interior finishes, and windows and louvers.

Figure 4.10 shows, for the concrete, steel, timber and timber-plus buildings (using the GaBi database), the total embodied $\mathrm{CO}_{2}$ for each of the five building components. 


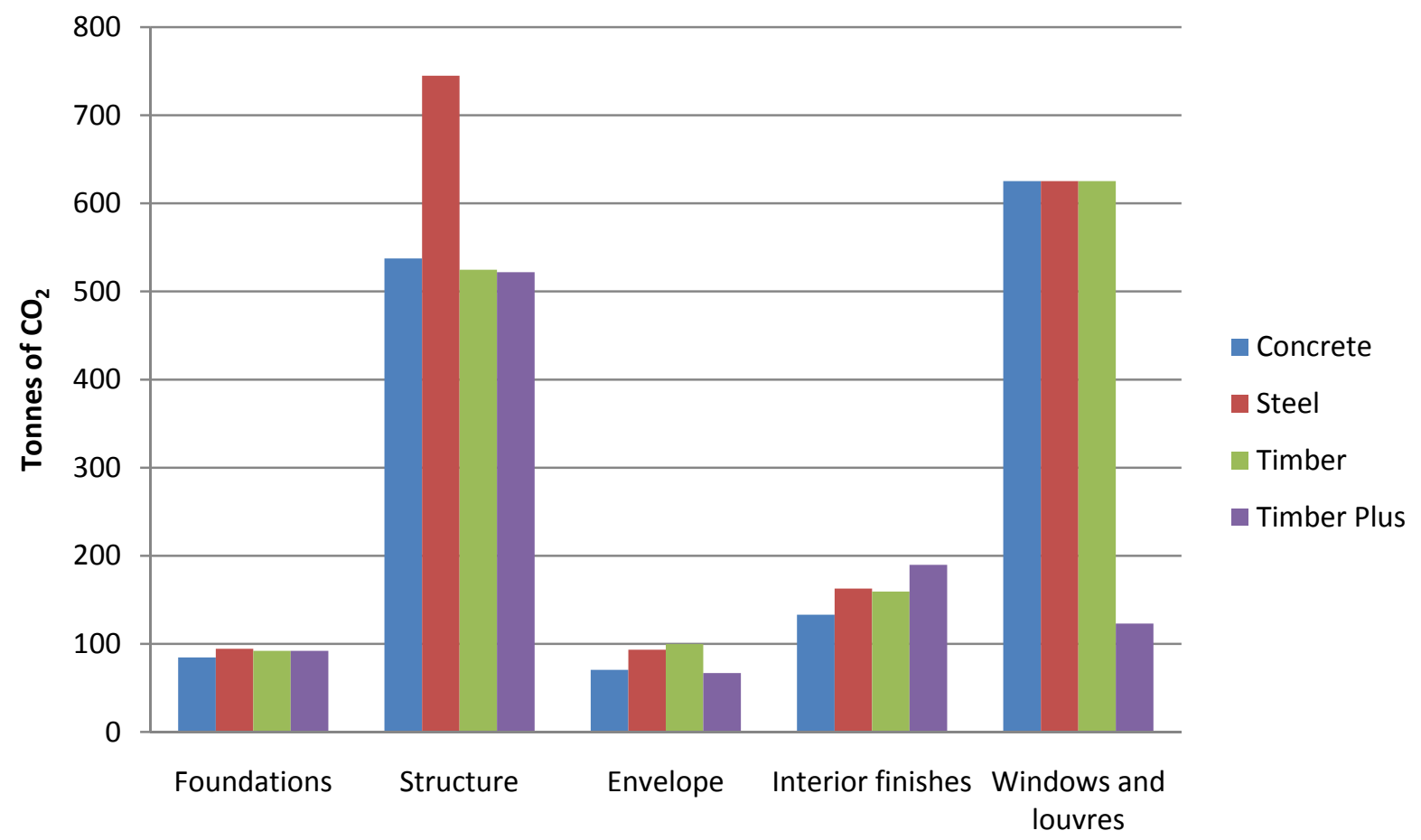

Figure 4-10: Total embodied $\mathrm{CO}_{2}$ segregated into five major building components (foundations, structure, envelope, interior finishes, and windows and louvers) for the four buildings (using the GaBi database).

It can be seen that on average windows and louvres ( $625 \mathrm{CO}_{2}$ tonnes) and structural systems (average of $528 \mathrm{CO}_{2}$ tonnes) each account for a high total of embodied $\mathrm{CO}_{2}$ emissions. The pattern changes particularly for windows and louvres in the timber-plus building and structural systems in the steel building. For the concrete, steel and timber buildings, windows and louvers average $625 \mathrm{CO}_{2}$ tonnes, in the timber-plus buildings (cedar louvers and windows frames) this accounts for only $123 \mathrm{CO}_{2}$ tonnes. On the other hand structural systems average in the concrete, timber and timber-plus buildings is $528 \mathrm{CO}_{2}$ tonnes, but in the steel building they account for $745 \mathrm{CO}_{2}$ tonnes.

The remaining three building components (foundations, envelope and interior finishes) had significantly lower total embodied $\mathrm{CO}_{2}$ emissions. The third largest initial $\mathrm{CO}_{2}$ emissions are for interior finishes, averaging 161 $\mathrm{CO}_{2}$ tonnes and ranging from $133 \mathrm{CO}_{2}$ tonnes in the concrete building to $190 \mathrm{CO}_{2}$ tonnes in the timber plus building. Foundations are responsible for the fourth largest total embodied $\mathrm{CO}_{2}$ emissions, averaging only 91 $\mathrm{CO}_{2}$ tonnes, a similar amount in all four buildings. The envelope is responsible for the lowest total embodied $\mathrm{CO}_{2}$ emissions, averaging $83 \mathrm{CO}_{2}$ tonnes and ranging from $67 \mathrm{CO}_{2}$ tonnes in the timber-plus building, to 100 $\mathrm{CO}_{2}$ tonnes in the timber building.

Figure 4.11 shows (using the Alcorn database) the total embodied energy of each of the five buildings components. It can be seen that the trend drastically changes compared with the trend seen before in Figure 4.10. There are some similarities in the patterns of building components such as the foundations and the windows and louvers, but this changes completely when looking at structural systems, envelope and interior 
finishes. This is not unexpected and is due to the influence of $\mathrm{CO}_{2}$ offsetting of timber materials within building components when the Alcorn database is used.

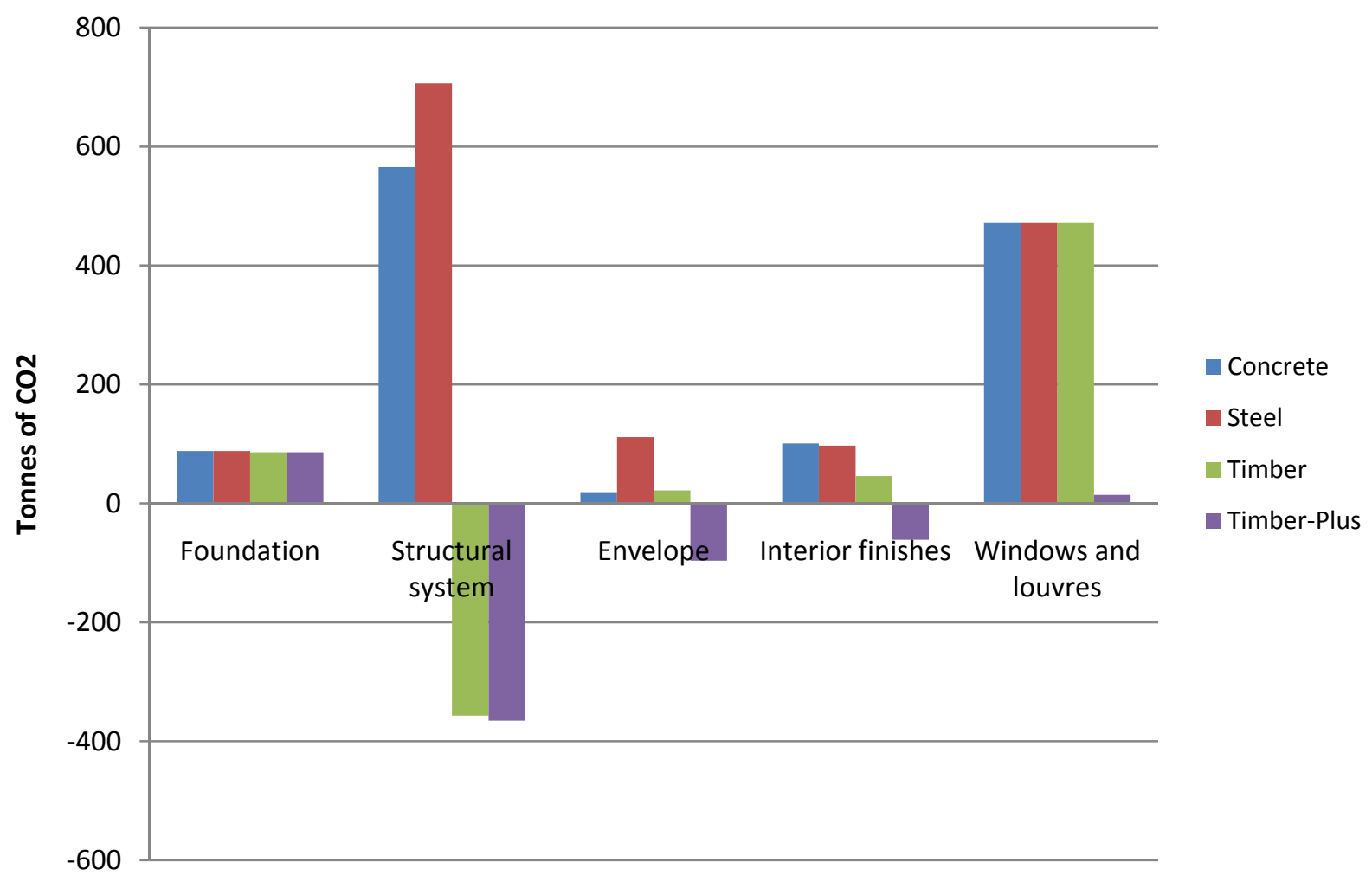

Figure 4-11: Total embodied $\mathrm{CO}_{2}$ segregated into five major building components for the concrete, steel, timber and timber-plus buildings (using the Alcorn database).

It can be seen that for all building components, structural systems are responsible for the highest and at the same time the lowest total embodied $\mathrm{CO}_{2}$ emissions. In the concrete and steel buildings, the structural systems account for 566 and $706 \mathrm{CO}_{2}$ tonnes respectively, and are the highest emissions compared to any other building components in Figure 4.11. On the other hand, the timber and timber-plus buildings have large negative total embodied $\mathrm{CO}_{2}$ emissions, being -357 and $-365 \mathrm{CO}_{2}$ tonnes respectively and accounting for the lowest emissions compared to any other building components in Figure 4.11.

As before, windows and louvers have a similar pattern in both Figure 4.10 and 4.11 and is the building component responsible for the second largest total embodied $\mathrm{CO}_{2}$ emissions. In Figure 4.11 this component averages $135 \mathrm{CO}_{2}$ tonnes less than in Figure 4.10 for the concrete, steel and timber buildings and $41 \mathrm{CO}_{2}$ tonnes less for the timber-plus building. As in Figure 4.10, in Figure 4.11 the remaining three building components (foundations, envelope and interior finishes) had significantly lower initial embodied $\mathrm{CO}_{2}$ emissions.

The third largest initial $\mathrm{CO}_{2}$ emissions are from interior finishes, with roughly the same $100 \mathrm{CO}_{2}$ tonnes as for the concrete and steel buildings. When looking at the timber building, this value is $46 \mathrm{CO}_{2}$ tonnes and in the timber-plus building this value is far lower, with a negative total embodied $\mathrm{CO}_{2}$ of $-96 \mathrm{CO}_{2}$ tonnes. As described in Chapter 3, all the other 3 buildings use lightweight partitions lined in Gypsum, but the timberplus building uses solid timber partitions and linings as interior wall finishes. This is why the value of this 
building component is negative compared with the same component in the other three buildings. In Figure 4.11 foundations are responsible for the fourth largest total embodied $\mathrm{CO}_{2}$ emissions, averaging only $87 \mathrm{CO}_{2}$ tonnes, which are similar in all four cases.

Similar than with Interior finishes the envelope is responsible for the lowest total embodied $\mathrm{CO}_{2}$ emissions. The timber used in the studs for the lightweight external walls and roof structure of the concrete and timber buildings offsets a large part of the $\mathrm{CO}_{2}$ emitted by the non-timber materials in that component. Both the concrete and the timber buildings account for roughly $20 \mathrm{CO}_{2}$ tonnes of total embodied emissions. The steel building accounts for $111 \mathrm{CO}_{2}$ tonnes due to the use of steel studs and steel corrugated cladding in the envelope (large embodied $\mathrm{CO}_{2}$ emissions for steel). The lowest of the envelope's total embodied $\mathrm{CO}_{2}$ emissions is in the timber-plus building with $-96 \mathrm{CO}_{2}$ tonnes due to the negative coefficient of the timber materials. 


\subsubsection{Total Life-Cycle $\mathrm{CO}_{2}$ Emissions}

This section adds the operating $\mathrm{CO}_{2}$ emissions to the total embodied $\mathrm{CO}_{2}$ emissions to get the total life-cycle $\mathrm{CO}_{2}$ emissions. Table 4.13 shows, for the concrete, steel, timber and timber-plus buildings, the 60 year life cycle $\mathrm{CO}_{2}$ emissions. The life-cycle $\mathrm{CO}_{2}$ emissions in $\mathrm{CO}_{2}$ tonnes accounts for the 60 year operational $\mathrm{CO}_{2}$ emissions, the initial embodied $\mathrm{CO}_{2}$ emissions and the 60 year recurrent embodied $\mathrm{CO}_{2}$ emissions. Each building has two results for the life-cycle $\mathrm{CO}_{2}$ emissions. This is because the initial and recurrent embodied $\mathrm{CO}_{2}$ emissions results were produced using both the $\mathrm{GaBi}$ and Alcorn databases.

\section{Operational $\mathrm{CO}_{2}$ emissions \\ 60 years operations \\ $\mathrm{CO}_{2}$ tonnes}

1 Concrete building

\begin{tabular}{|c|}
\hline 7,239 Tonnes \\
\hline $2.05 \mathrm{t} / \mathrm{m}^{2}$ \\
\hline
\end{tabular}

$85 \%$

2 Steel building

\begin{tabular}{|c|}
\hline 7,377 Tonnes \\
\hline $2.09 \mathrm{t} / \mathrm{m}^{2}$ \\
\hline
\end{tabular}

$83 \%$

4 Timber building

\begin{tabular}{|c|}
\hline 7,654 Tonnes \\
\hline $2.16 \mathrm{t} / \mathrm{m}^{2}$ \\
\hline
\end{tabular}

$97 \%$

Alcorn \begin{tabular}{c|}
245 Tonnes \\
\cline { 2 - 2 } \\
\hline
\end{tabular}

$3 \%$

Embodied $\mathrm{CO}_{2}$ emissions

Initial embodied $\mathrm{CO}_{2}$ plus

recurrent embodied $\mathrm{CO}_{2}$

$\mathrm{CO}_{2}$ tonnes
Life-cycle $\mathrm{CO}_{2}$ emissions

Operational $\mathrm{CO}_{2}$ plus

total embodied $\mathrm{CO}_{2}$

$\mathrm{CO}_{2}$ tonnes

\begin{tabular}{|c|c|c|c|c|}
\hline \multirow[t]{2}{*}{ Gabi } & 1,451 Tonnes & \multirow[t]{2}{*}{$17 \%$} & 8,690 Tonnes & \multirow[t]{2}{*}{$100 \%$} \\
\hline & $0.41 \mathrm{t} / \mathrm{m}^{2}$ & & $2.46 \mathrm{t} / \mathrm{m}^{2}$ & \\
\hline \multirow[t]{2}{*}{ Alcorn } & 1,245 Tonnes & \multirow[t]{2}{*}{$15 \%$} & 8,484 Tonnes & \multirow[t]{2}{*}{$100 \%$} \\
\hline & $0.35 \mathrm{t} / \mathrm{m}^{2}$ & & $2.40 \mathrm{t} / \mathrm{m}^{2}$ & \\
\hline
\end{tabular}

\begin{tabular}{|c|c|c|c|c|}
\hline \multirow[t]{2}{*}{ Gabi } & 1,674 Tonnes & \multirow[t]{2}{*}{$18 \%$} & 9,052 Tonnes & \multirow[t]{2}{*}{$100 \%$} \\
\hline & $0.47 \mathrm{t} / \mathrm{m}^{2}$ & & $2.56 \mathrm{t} / \mathrm{m}^{2}$ & \\
\hline \multirow[t]{2}{*}{ Alcorn } & 1,491 Tonnes & \multirow[t]{2}{*}{$17 \%$} & 8,868 Tonnes & \multirow[t]{2}{*}{$100 \%$} \\
\hline & $0.42 \mathrm{t} / \mathrm{m}^{2}$ & & $2.51 \mathrm{t} / \mathrm{m}^{2}$ & \\
\hline
\end{tabular}

\begin{tabular}{|c|c|c|c|c|}
\hline \multirow[t]{2}{*}{ Gabi } & 1,528 Tonnes & \multirow[t]{2}{*}{$17 \%$} & 9,182 Tonnes & \multirow[t]{2}{*}{$100 \%$} \\
\hline & $0.43 \mathrm{t} / \mathrm{m}^{2}$ & & $2.60 \mathrm{t} / \mathrm{m}^{2}$ & \\
\hline \multirow[t]{2}{*}{ Alcorn } & 245 Tonnes & \multirow[t]{2}{*}{$3 \%$} & 7,899 Tonnes & \multirow[t]{2}{*}{$100 \%$} \\
\hline & $0.07 \mathrm{t} / \mathrm{m}^{2}$ & & $2.23 \mathrm{t} / \mathrm{m}^{2}$ & \\
\hline
\end{tabular}

3 Timber-Plus building

\begin{tabular}{|c|}
\hline 7,426 Tonnes \\
\hline $2.10 \mathrm{t} / \mathrm{m}^{2}$ \\
\hline
\end{tabular}

$106 \%$

\begin{tabular}{|c|c|c|c|c|}
\hline \multirow[t]{2}{*}{ Gabi } & 1,021 Tonnes & \multirow[t]{2}{*}{$12 \%$} & 8,447 Tonnes & \multirow[t]{2}{*}{$100 \%$} \\
\hline & $0.29 \mathrm{t} / \mathrm{m}^{2}$ & & $2.39 \mathrm{t} / \mathrm{m}^{2}$ & \\
\hline \multirow{2}{*}{ Alcorn } & -446 Tonnes & \multirow[t]{2}{*}{$-6 \%$} & 6,980 Tonnes & \multirow[t]{2}{*}{$100 \%$} \\
\hline & $-0.13 \mathrm{t} / \mathrm{m} 2$ & & $1.97 \mathrm{t} / \mathrm{m} 2$ & \\
\hline
\end{tabular}

Net Usable Area:

$3,536 \mathrm{~m}^{2}$

Table 4.13: Total 60 year life-cycle $\mathrm{CO}_{2}$ emissions, including 60 years of $\mathrm{CO}_{2}$ emissions in operation, and total embodied energy (initial embodied $\mathrm{CO}_{2}$ emissions plus recurrent embodied $\mathrm{CO}_{2}$ emissions) using embodied $\mathrm{CO}_{2}$ coefficients based on the $\mathrm{GaBi}$ and Alcorn databases. 
When using the $\mathrm{GaBi}$ database, 60 years of operating $\mathrm{CO}_{2}$ emissions range from $83 \%$ of the total life-cycle $\mathrm{CO}_{2}$ emissions in the timber building $\left(7,654\right.$ tonnes of $\left.\mathrm{CO}_{2}\right)$ which has the highest life-cycle $\mathrm{CO}_{2}$ emissions to $88 \%$ in the timber-plus building $\left(7,426\right.$ tonnes of $\left.\mathrm{CO}_{2}\right)$ which has the lowest life-cycle $\mathrm{CO}_{2}$ emissions. The initial embodied $\mathrm{CO}_{2}$ emissions range from $14 \%$ of the total life cycle $\mathrm{CO}_{2}$ emissions in the timber building (1,308 tonnes of $\mathrm{CO}_{2}$ ) to $10 \%$ in the timber-plus building (862 tonnes of $\mathrm{CO}_{2}$ ). Finally, recurrent embodied $\mathrm{CO}_{2}$ emissions account for roughly $3 \%$ of the total life-cycle energy use for all cases (149-220 tonnes of $\mathrm{CO}_{2}$ ).

When using the Alcorn database, the trend changes, now the timber-plus building has the lowest life-cycle $\mathrm{CO}_{2}$ emissions and the steel building has the highest life-cycle $\mathrm{CO}_{2}$ emissions. The 60 years of operating $\mathrm{CO}_{2}$ emissions range from $83 \%$ in the steel building $\left(7,377\right.$ tonnes of $\left.\mathrm{CO}_{2}\right)$ to $106 \%$ in the timber-plus building $\left(7,426\right.$ tonnes of $\left.\mathrm{CO}_{2}\right)$. The initial embodied $\mathrm{CO}_{2}$ emissions range from $15 \%$ of the life-cycle $\mathrm{CO}_{2}$ emissions in the steel building $\left(1,325\right.$ tonnes of $\left.\mathrm{CO}_{2}\right)$ to $-5.7 \%$ in the timber-plus building (-395 tonnes of $\mathrm{CO}_{2}$ ), due to the negative initial embodied $\mathrm{CO}_{2}$ emissions. Recurrent embodied $\mathrm{CO}_{2}$ emissions range from $2 \%$ of the life-cycle $\mathrm{CO}_{2}$ emissions in the steel building (166 tonnes of $\mathrm{CO}_{2}$ ) to $-0.7 \%$ in the timber-plus building (-51 tonnes of $\mathrm{CO}_{2}$ ). All of the negative percentages in the timber-plus building are due to the negative embodied $\mathrm{CO}_{2}$ emissions.

\subsubsection{Ranking of buildings' life-cycle $\mathrm{CO}_{2}$ emissions}

In contrast to the life-cycle energy use, when looking at the total life-cycle $\mathrm{CO}_{2}$ emissions of the concrete, steel, timber and timber-plus buildings using both the $\mathrm{GaBi}$ and the Alcorn databases the trend changes between the two sets of results.

In results using the $\mathrm{GaBi}$ database, the timber-plus building has the lowest life-cycle $\mathrm{CO}_{2}$ emissions with a total of $8,447 \mathrm{CO}_{2}$ tonnes. The timber-plus building is followed by the concrete building with $244 \mathrm{CO}_{2}$ tonnes more. Next is the steel building with $605 \mathrm{CO}_{2}$ tonnes more. Finally the total highest $\mathrm{CO}_{2}$ emissions are for the timber building with $736 \mathrm{CO}_{2}$ tonnes more than the life-cycle $\mathrm{CO}_{2}$ emissions of the timber-plus building.

When the Alcorn database is used, the timber-plus building also has the shorter life-cycle $\mathrm{CO}_{2}$ emissions with $6,980 \mathrm{CO}_{2}$ tonnes. The timber-plus building is followed by the timber building with $919 \mathrm{CO}_{2}$ tonnes more. Next is the concrete building with $1,504 \mathrm{CO}_{2}$ tonnes more. The highest life-cycle emissions are in the steel building accounting for $1,888 \mathrm{CO}_{2}$ tonnes more than the life-cycle $\mathrm{CO}_{2}$ emissions of the timber-plus building.

In the results, using both coefficients, the timber-plus building has the lowest life-cycle $\mathrm{CO}_{2}$ emissions accounting for a total of $8,447 \mathrm{CO}_{2}$ tonnes when using the $\mathrm{GaBi}$ database coefficients and $6,980 \mathrm{CO}_{2}$ tonnes when Alcorn's coefficients are used. At the other end of the spectrum, using the GaBi database the highest emissions are for the timber building with $736 \mathrm{CO}_{2}$ tonnes more than the timber-plus building and using the Alcorn database, the largest life-cycle emissions are in the steel building accounting for $1,888 \mathrm{CO}_{2}$ tonnes more than the timber-plus building. 
Figure 4.12 shows, for the concrete, steel, timber and timber-plus buildings, the operating $\mathrm{CO}_{2}$ emissions, initial embodied $\mathrm{CO}_{2}$ emissions, recurrent embodied $\mathrm{CO}_{2}$ emissions and the total life-cycle $\mathrm{CO}_{2}$ emissions. Initial and recurrent $\mathrm{CO}_{2}$ emissions in this graph were produced using the $\mathrm{GaBi}$ database and operating energy was produced by energy performance simulations using Design Builder software.

Operating $\mathrm{CO}_{2}$ emissions in this graph represent $83 \%$ of the total life-cycle $\mathrm{CO}_{2}$ emissions for the concrete, steel and timber building and $88 \%$ for the timber-plus building. Initial and recurrent $\mathrm{CO}_{2}$ emissions account for the remaining $17 \%$ of the life-cycle $\mathrm{CO}_{2}$ emissions for the concrete, steel and timber buildings with $12 \%$ for the timber-plus building.

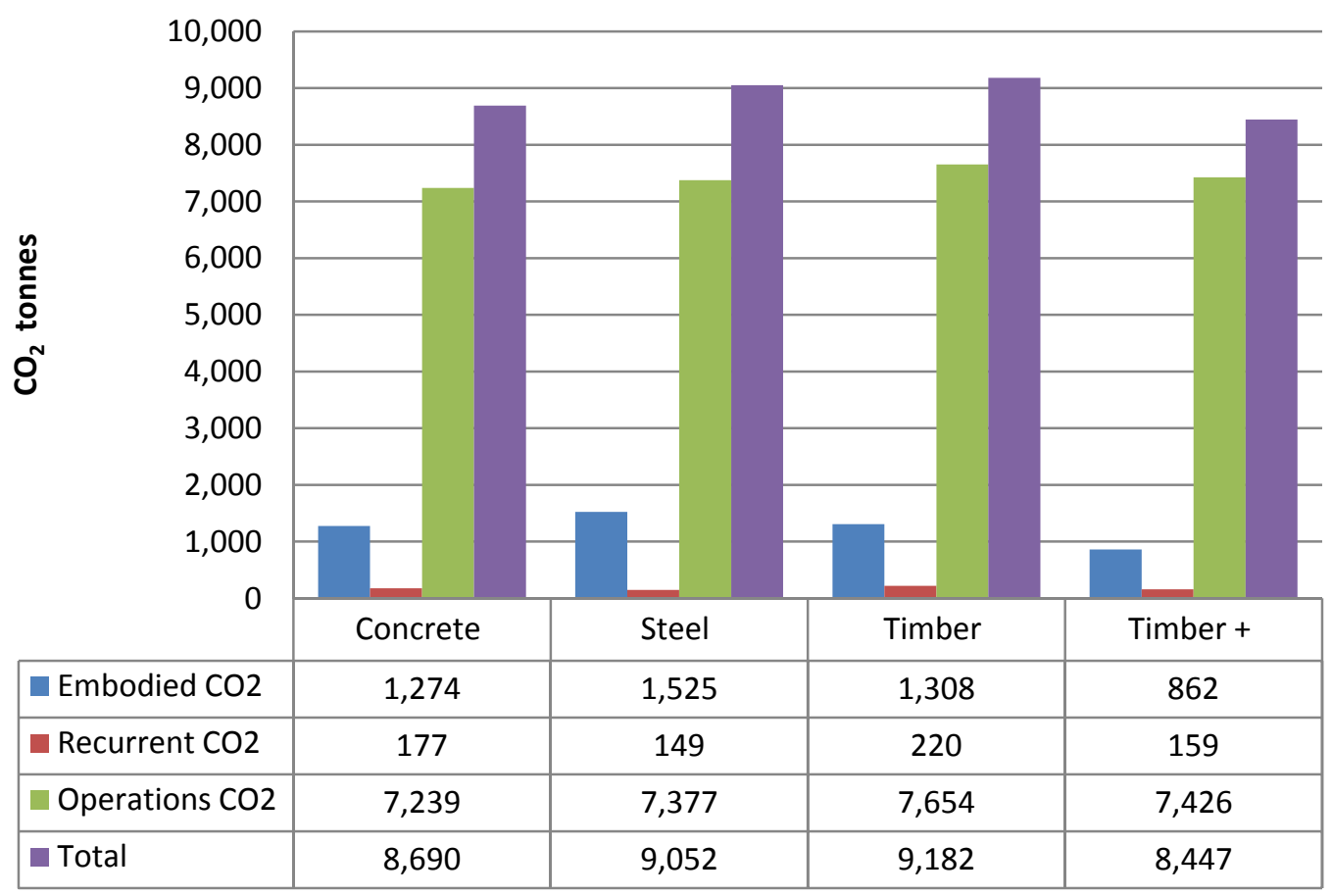

Figure 4-12: Life-cycle $\mathrm{CO}_{2}$ emissions using the $\mathrm{GaBi}$ database for the calculation of initial and recurrent embodied $\mathrm{CO}_{2}$ emissions.

There is a total difference between the lowest (timber-plus building) and the highest (timber building) lifecycle $\mathrm{CO}_{2}$ emission of $736 \mathrm{CO}_{2}$ tonnes and this represents a $9 \% \mathrm{CO}_{2}$ emissions increment of the timber building over the timber-plus building. Following the timber-plus building (lowest emissions) is the concrete building, then the steel building life-cycle $\mathrm{CO}_{2}$ emissions. Looking at the difference in life-cycle $\mathrm{CO}_{2}$ emissions, there are $244 \mathrm{CO}_{2}$ tonnes more in the concrete building compared with the timber-plus building, which represents a $3 \%$ increment in the life-cycle emissions of the concrete over the timber-plus building. Between the concrete building and the steel building there is a difference of $361 \mathrm{CO}_{2}$ tonnes, which represents a $4 \%$ increment in the steel building's life-cycle $\mathrm{CO}_{2}$ emissions. Finally, between the steel and the timber building there is a difference of $131 \mathrm{CO}_{2}$ tonnes representing a $1 \%$ increment of the life-cycle $\mathrm{CO}_{2}$ emissions of the timber building over the steel building. 
Figure 4.13 shows, for the concrete, steel, timber and timber-plus buildings, the operating $\mathrm{CO}_{2}$ emissions, initial embodied $\mathrm{CO}_{2}$ emissions, recurrent embodied $\mathrm{CO}_{2}$ emissions and the total life-cycle $\mathrm{CO}_{2}$ emissions. Initial and recurrent $\mathrm{CO}_{2}$ emissions in this graph were produced using the Alcorn database and operating energy was produced by energy performance simulations using Design Builder software. Operating $\mathrm{CO}_{2}$ emissions in this graph represent $86 \%$ of the total life-cycle $\mathrm{CO}_{2}$ emissions for the concrete and steel building, $94 \%$ for the timber building and $106 \%$ for the timber-plus building. Initial and recurrent $\mathrm{CO}_{2}$ emissions account for the remaining $14 \%$ of the total life-cycle $\mathrm{CO}_{2}$ emissions of the concrete and steel building, $6 \%$ for the timber building and $-6 \%$ for the timber-plus building.

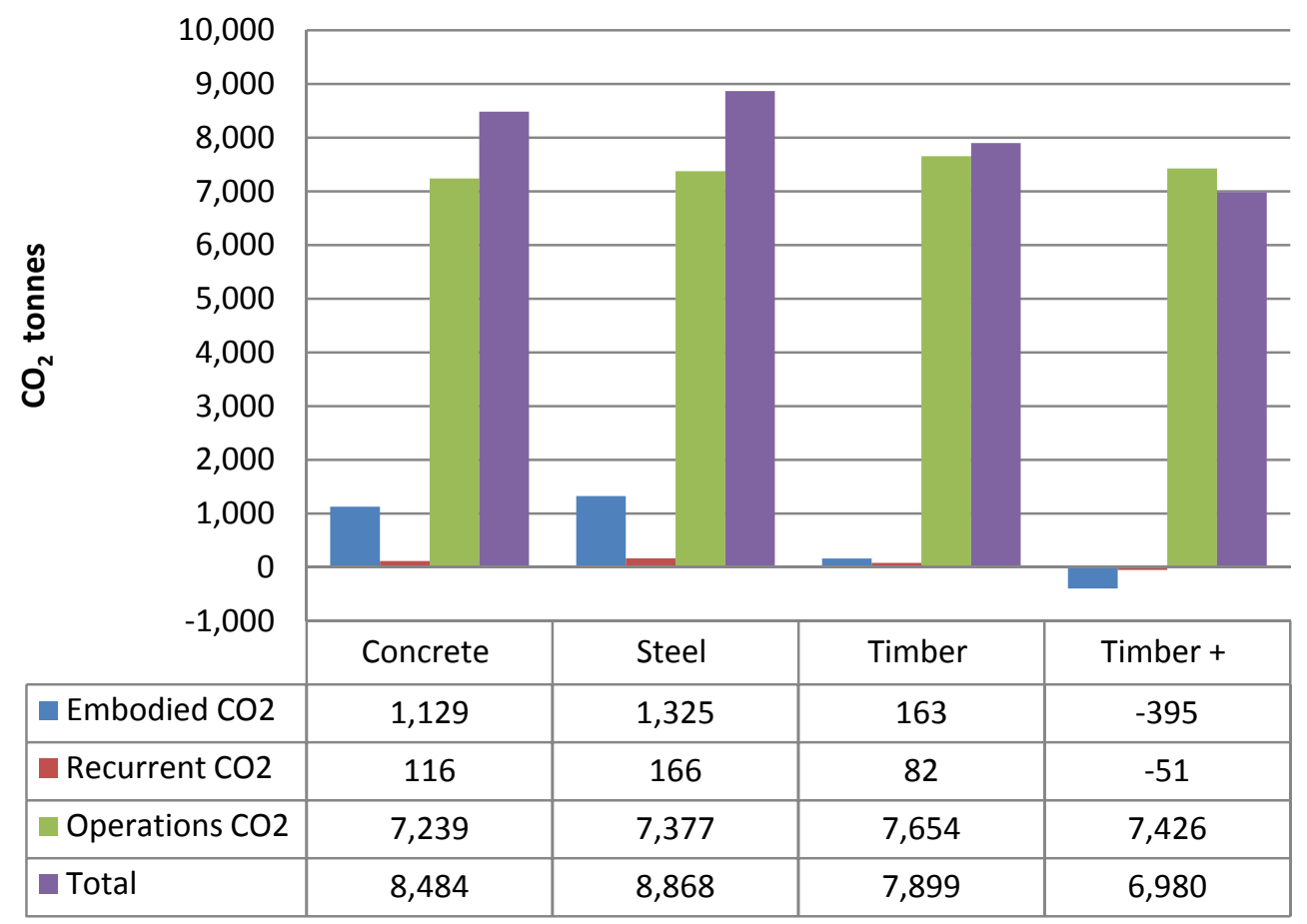

Figure 4-13: Life-cycle $\mathrm{CO}_{2}$ emissions using the Alcorn database to calculate the initial and recurrent embodied $\mathrm{CO}_{2}$ emissions.

There is a maximum difference between the lowest (timber-plus building) and highest (timber building) lifecycle $\mathrm{CO}_{2}$ emissions of $1,888 \mathrm{CO}_{2}$ tonnes and this represents a $27 \% \mathrm{CO}_{2}$ emissions increment in the steel building over the timber-plus building. Following the timber-plus building (which has the lowest life-cycle emissions) is the timber building, then the concrete building and finally the steel building. Looking at the differences in life-cycle $\mathrm{CO}_{2}$ emissions, there are $919 \mathrm{CO}_{2}$ tonnes more in the timber building compared with the timber-plus building, representing a 13\% increment. Between the timber and the concrete building there is a difference of $585 \mathrm{CO}_{2}$ tonnes, this represents a $7 \%$ life-cycle $\mathrm{CO}_{2}$ emissions increment of the concrete over the timber building. Lastly, between the concrete and the steel building there is a $385 \mathrm{CO}_{2}$ tonnes of difference, representing a $5 \%$ increment in the life-cycle $\mathrm{CO}_{2}$ emissions of the steel over the concrete building. 


\subsubsection{Summary of the life-cycle $\mathrm{CO}_{2}$ emissions}

When the method of calculation of the initial embodied $\mathrm{CO}_{2}$ emissions and the recurrent embodied $\mathrm{CO}_{2}$ emissions change, the proportion between components of the life-cycle $\mathrm{CO}_{2}$ emissions of the building change significantly. When the $\mathrm{GaBi}$ database is used, the maximum difference between life-cycle $\mathrm{CO}_{2}$ emissions is $780 \mathrm{CO}_{2}$ tonnes, while when the Alcorn database is used that difference is $1,888 \mathrm{CO}_{2}$ tonnes. This represents a large difference, since the results produced using the Aclorn database are 2.4 times the results produced using the GaBi database. Differences between the four cases are also moderated when the $\mathrm{GaBi}$ database is used, averaging $245 \mathrm{CO}_{2}$ tonnes compared with $630 \mathrm{CO}_{2}$ tonnes when the Alcorn database is used.

It can be said that when the $\mathrm{GaBi}$ database is used, the total embodied $\mathrm{CO}_{2}$ emissions is equivalent to a range of 8 years of operational $\mathrm{CO}_{2}$ emissions in the timber-plus building to 14 years in the steel building. On the other hand, when the Alcorn database is used, total embodied energy is equivalent to a range of 0 years of operational $\mathrm{CO}_{2}$ emissions in the timber-plus building, to 12 years in the steel building.

In Chapter 3, Section 3.5.1, a study of the differences between the two databases is given. These differences are placed into three groups: country/region related differences, differences in inventory analysis and differences in impact assessment categories. A research study assessing these differences (Szalay \& Nebel, 2006) found that there is no general trend for Alcorn data to be lower or higher than GaBi data. The same research stated that some building materials, such as aluminium and timber in the Alcorn data are lower, and others such as cement, gypsum board or steel are higher.

Nevertheless, by showing the results of total embodied $\mathrm{CO}_{2}$ emission produced using the two different databases, this thesis demonstrates that the impact of timber $\mathrm{CO}_{2}$ sequestration on the life-cycle $\mathrm{CO}_{2}$ is evident and makes a major difference to the outcome of the assessment when these two different databases are applied. Because timber is not only used in the timber and timber-plus buildings, but also in interior and exterior light-weight walls of the concrete building, timber components when using $\mathrm{GaBi}$, add embodied $\mathrm{CO}_{2}$ to the building, however, when using Alcorn, timber components offset $\mathrm{CO}_{2}$ emitted by other carbonaceous materials.

On the other hand, it is evident that finishing materials (such as aluminium) can add large volumes of embodied $\mathrm{CO}_{2}$ emissions to a building and that the simple replacement of this with timber (cedar) can make a big difference to the life-cycle $\mathrm{CO}_{2}$ emissions. Windows and louvres are the components that account for the largest total embodied $\mathrm{CO}_{2}$ emissions when the $\mathrm{GaBi}$ data was used, and the second largest total embodied $\mathrm{CO}_{2}$ emissions when the Alcorn database was used. Total embodied $\mathrm{CO}_{2}$ emissions of windows and louvers can be reduced by $70 \%$ if aluminium is replaced by cedar, for example. 
Results 


\section{Discussion}

This chapter discusses the results of the thesis, and compares the performance of each of the four case studies produced in this research against other published research studies. The rationale of this chapter is to combine the results for energy and $\mathrm{CO}_{2}$ emissions simultaneously. This combination condenses the large amount of data produced by this thesis to allow the achievement of clear conclusions.

This chapter is organised into five sections. Section 5.1 presents the results of the life-cycle operating energy consumption and operating $\mathrm{CO}_{2}$ emissions. Operating energy will be segregated into energy end-uses, and then the energy consumption and the $\mathrm{CO}_{2}$ emissions will be presented in an attempt to identify the influence of materials on the operating energy consumption and operating $\mathrm{CO}_{2}$ emissions.

Section 5.2 presents the total embodied energy and total embodied $\mathrm{CO}_{2}$ emissions in the concrete, steel, timber and timber-plus buildings. Data on embodied energy and embodied $\mathrm{CO}_{2}$ emissions is separated into the results produced using the $\mathrm{GaBi}$ database and those produced using the Alcorn database. Finally Section 5.2 will compare both sets of results.

Section 5.3 discuses the results produced when total embodied energy and total embodied $\mathrm{CO}_{2}$ emissions are segregated into major building components. Section 5.3 also discusses the influence of finishing materials on the total embodied energy and total embodied $\mathrm{CO}_{2}$ emissions of the four buildings. Following this is an assessment of how the replacement of finishing materials with high embodied energy and $\mathrm{CO}_{2}$ emissions, by materials with low embodied energy and $\mathrm{CO}_{2}$ emissions can drastically reduce the total embodied energy and total embodied $\mathrm{CO}_{2}$ emissions of buildings.

Section 5.4 discusses the total life-cycle energy consumption and $\mathrm{CO}_{2}$ emissions of each of the four case studies. Since embodied energy and embodied $\mathrm{CO}_{2}$ emissions are calculated using both the Alcorn and the $\mathrm{GaBi}$ databases, this section is separated into the results produced using each of the databases. Finally Section 5.4 will compare both sets of results.

To conclude the chapter a summary of the main findings will be presented. 


\subsection{Life-cycle operating energy consumption and $\mathrm{CO}_{2}$ emissions}

As was explained in Section 3.4, the four buildings were designed to have a similar operating energy consumption. This required different designs for envelope walls' construction, thermal mass, and heating and cooling equipment in each of the four buildings. Having similar operational energy consumption will highlight any difference in the embodied and recurrent energy and $\mathrm{CO}_{2}$ emissions in the materials used in each building. Section 5.1 presents the results of the life-cycle operating energy consumption and operating $\mathrm{CO}_{2}$ emissions. Table 5.1 shows, for the concrete, steel, timber and timber-plus buildings, the annual energy consumption in operation and the annual $\mathrm{CO}_{2}$ emissions in operation both multiplied by a 60 year life-cycle.

\section{Operating energy}

\begin{tabular}{|c|c|}
\hline Annual & $\begin{array}{r}\text { Life-cycle } \\
60 \text { years }\end{array}$ \\
\hline $\mathrm{kWh} / \mathrm{y}$ & GJ \\
\hline
\end{tabular}

\section{Operating $\mathrm{CO}_{2}$}

\begin{tabular}{lr} 
Annual & $\begin{array}{r}\text { Life-cycle } \\
60 \text { years }\end{array}$ \\
\hline $\mathrm{t} \mathrm{CO}_{2} / \mathrm{yr}$ & $\mathrm{CO}_{2}$ tonnes
\end{tabular}

1 Concrete building

\begin{tabular}{r|r|} 
Total electricity & 241,171 \\
Total Gas & 55,764 \\
\cline { 2 - 2 } Total energy use & $\mathbf{2 9 6 , 9 3 5}$ \\
\cline { 2 - 2 } & $\mathbf{8 4}$ \\
\hline Total energy use $/ \mathbf{m}^{2}$ & $\mathbf{1}$
\end{tabular}

\begin{tabular}{|c|c|}
\hline 868 & 52,093 \\
\hline 201 & 12,045 \\
\hline 1,069 & 64,138 \\
\hline 0.30 & 18.14 \\
\hline
\end{tabular}

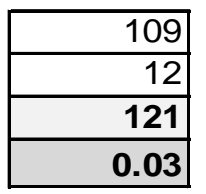

\begin{tabular}{|r|}
\hline 6,512 \\
\hline 728 \\
\hline $\mathbf{7 , 2 3 9}$ \\
\hline $\mathbf{2 . 0 5}$ \\
\hline
\end{tabular}

2 Steel building

\begin{tabular}{|c|c|c|c|c|c|}
\hline Total electricity & 245,999 & 886 & 53,136 & 111 & 6,642 \\
\hline Total Gas & 56,365 & 203 & 12,175 & 12 & 735 \\
\hline Total energy use: & 302,363 & 1,089 & 65,310 & 123 & 7,377 \\
\hline Total energy use $/ \mathrm{m}^{2}$ & 86 & 0.31 & 18.47 & 0.03 & 2.09 \\
\hline
\end{tabular}

3 Timber building

\begin{tabular}{|c|c|c|c|c|c|}
\hline Total electricity & 257,433 & 927 & 55,606 & 116 & 6,951 \\
\hline Total Gas & 53,934 & 194 & 11,650 & 12 & 704 \\
\hline Total energy use: & 311,367 & 1,121 & 67,255 & 128 & 7,654 \\
\hline Total energy use $/ \mathrm{m}^{2}$ & 88 & 0.32 & 19.02 & 0.04 & 2.16 \\
\hline
\end{tabular}

4 Timber-Plus building Total electricity Total Gas

Total energy use:

Total energy use/m ${ }^{2}$

\begin{tabular}{|r|}
\hline 247,271 \\
\hline 57,470 \\
\hline $\mathbf{3 0 4 , 7 4 0}$ \\
\hline $\mathbf{8 6}$ \\
\hline
\end{tabular}

\begin{tabular}{|r|}
\hline 890 \\
\hline 207 \\
\hline 1,097 \\
\hline 0.31 \\
\hline
\end{tabular}

\begin{tabular}{|r|}
\hline 53,410 \\
\hline 12,413 \\
\hline $\mathbf{6 5 , 8 2 4}$ \\
\hline $\mathbf{1 8 . 6 1}$ \\
\hline
\end{tabular}
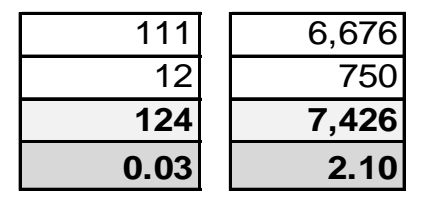

Net Usable Area:

$3,536 \quad \mathrm{~m}^{2}$

Table 5.1: Annual and life-cycle (60 year) operating energy consumption and operating $\mathrm{CO}_{2}$ emissions

As can be seen in Table 5.1, annual energy consumption in the operation of the concrete, steel, timber and timber-plus buildings, when they are designed to have similar operating energy consumption, is fairly similar 
but not equal. This finding is similar to what was found in Cole and Kernan (1996), where the research found that the differences in operational energy between wood, steel and concrete framed buildings are negligible.

The results of operating energy consumption range from $84 \mathrm{kWh} / \mathrm{m}^{2} . \mathrm{yr}$ in the concrete building to 88 $\mathrm{kWh} / \mathrm{m}^{2} \times \mathrm{yr}$ in the timber building. This range represents a small difference of $5 \%$ increment of the highest operating energy consumption over the lowest. Operating $\mathrm{CO}_{2}$ emissions range from $34.1 \mathrm{CO}_{2} \mathrm{Kg} / \mathrm{m}^{2} . \mathrm{yr}$ in the concrete building to $36.1 \mathrm{CO}_{2} \mathrm{Kg} / \mathrm{m}^{2} . \mathrm{yr}$ in the timber building. This difference represents a $6 \%$ increment of the highest $\mathrm{CO}_{2}$ emissions over the lowest.

Previous research has found that the operating $\mathrm{CO}_{2}$ emissions are proportional to the amount of energy consumed (Suzuki \& Oka, 1998). This thesis found an equivalence between operating energy consumption and operating $\mathrm{CO}_{2}$ emissions.

\subsubsection{Operating energy consumption end-uses}

Figure 5.1 shows, for the concrete, steel, timber and timber-plus buildings, the proportion breakdown of the end-uses energy consumption in GJ/yr.

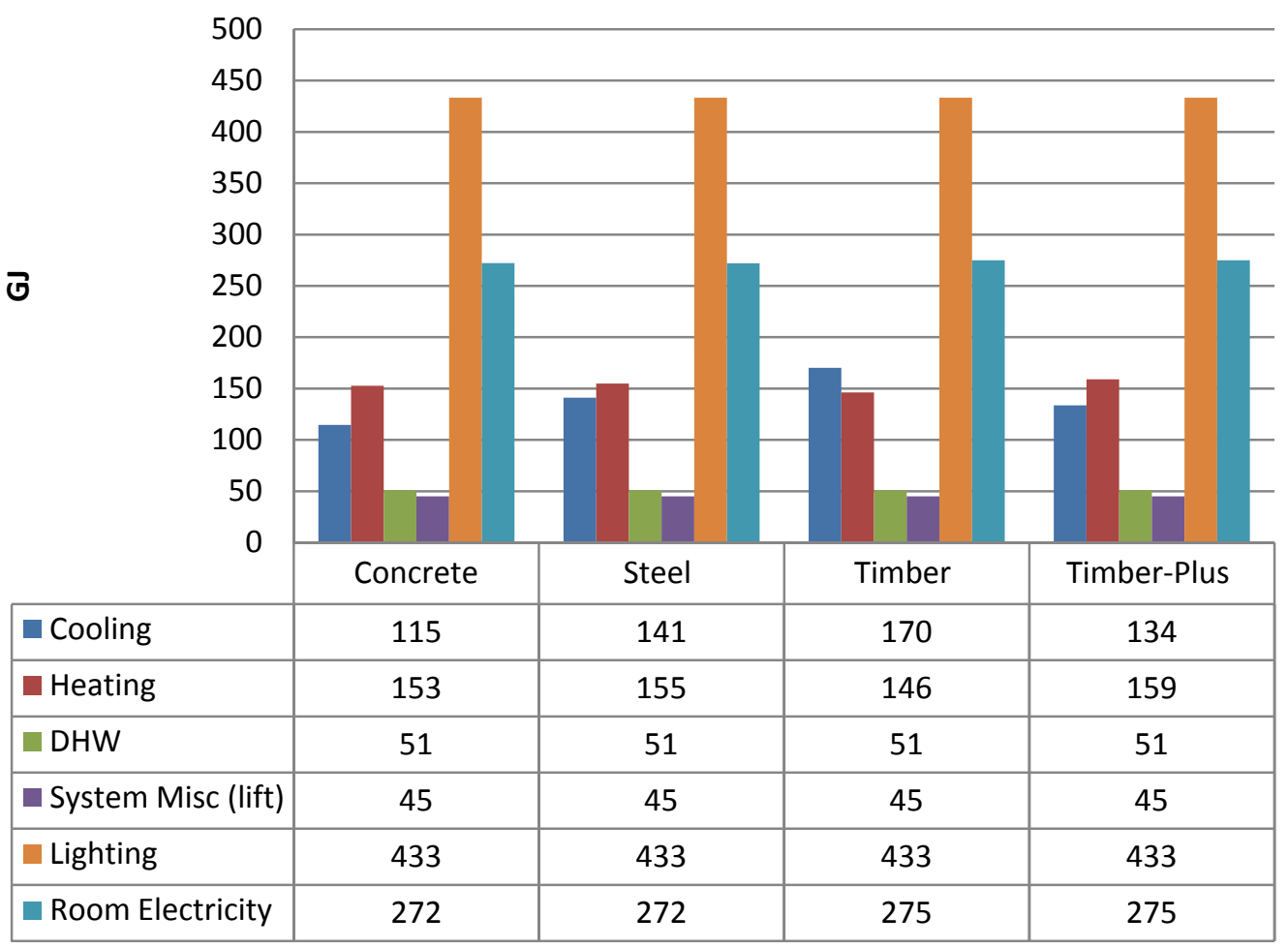

Figure 5-1: Annual operational energy segregated into end-uses for the four buildings.

For the four buildings analysed in this research, lighting energy consumption is by far the largest energy enduse, consuming $34 \mathrm{kWh} / \mathrm{m}^{2}$ and representing a $39 \%$ of the total annual operating energy consumption. Lighting is followed by room electricity with an energy consumption that ranges from $20.7 \mathrm{kWh} / \mathrm{m}^{2}$ in the steel building to $21.6 \mathrm{kWh} / \mathrm{m}^{2}$ in the timber and timber-plus building. This represents roughly $25 \%$ of the total 
annual operating energy consumption. The third highest end-use energy consumption is cooling, ranging from $9 \mathrm{kWh} / \mathrm{m}^{2}$ in the concrete building to $13.4 \mathrm{kWh} / \mathrm{m}^{2}$ in the timber building, representing roughly $13 \%$ of the total annual operating energy consumption. Heating accounts for the fourth highest end-use energy consumption, ranging from $11.5 \mathrm{kWh} / \mathrm{m}^{2}$ in the timber building to $12.5 \mathrm{kWh} / \mathrm{m}^{2}$ in the timber-plus building, representing $14 \%$ of the total annual operating energy consumption. The remaining end-uses are domestic hot water $(\mathrm{DWH})$ and system miscellaneous, together representing $7 \%$ of the total annual operating energy consumption.

\subsubsection{Operating $\mathrm{CO}_{2}$ emission end-uses}

When looking at end-uses' annual $\mathrm{CO}_{2}$ emissions, this end-uses represents fairly similar percentages to the percentages of end-uses' annual operating energy consumption.

Figure 5.2 shows both the percentage of energy consumption and $\mathrm{CO}_{2}$ emissions in the end-uses within the total operating energy consumption and $\mathrm{CO}_{2}$ emissions for the concrete, steel, timber and timber-plus buildings.

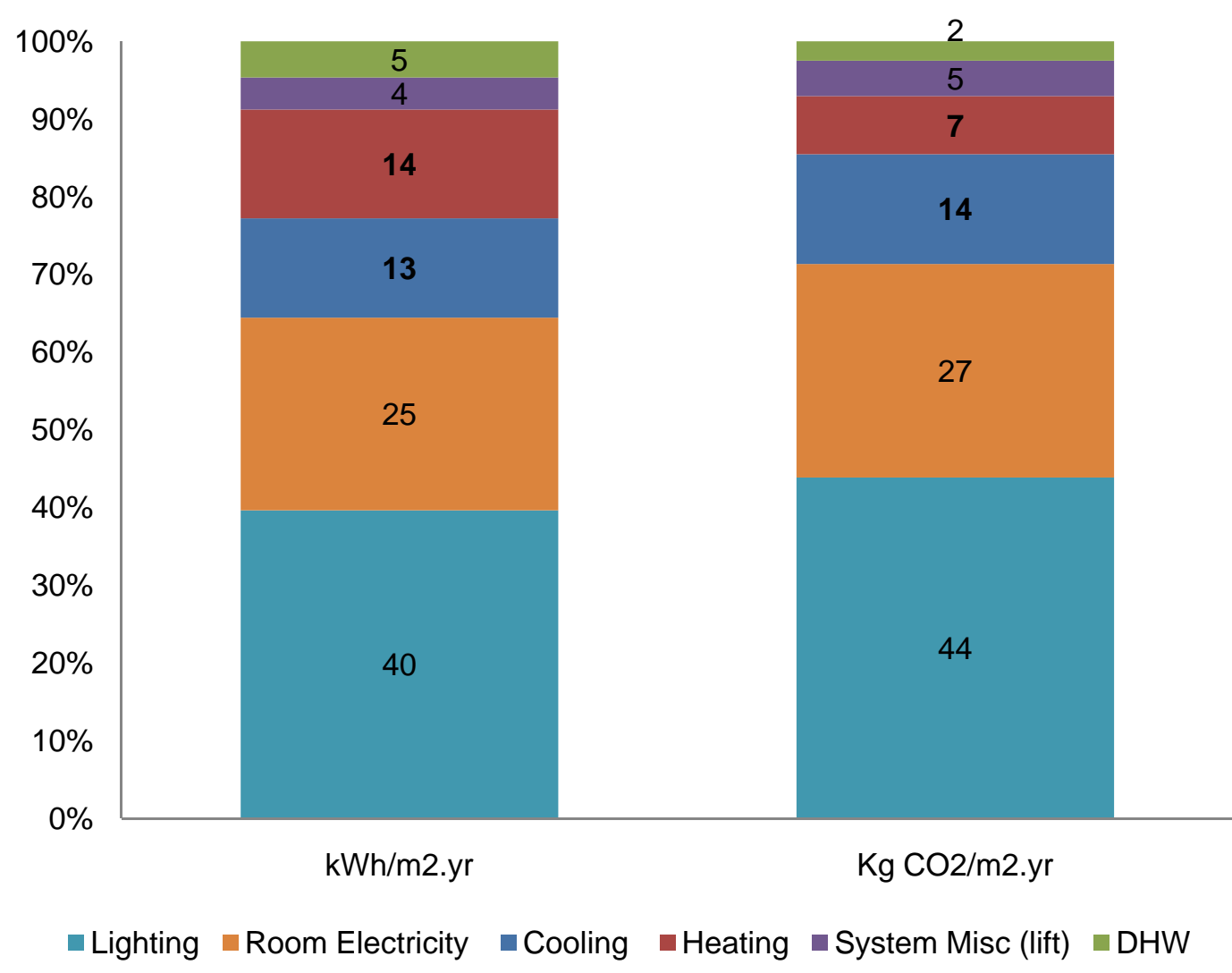

Figure 5-2: Percentages of energy consumption and $\mathrm{CO}_{2}$ emissions in end-uses.

Lighting accounts for the largest $\mathrm{CO}_{2}$ emissions $\left(15.3 \mathrm{CO}_{2} \mathrm{Kg} / \mathrm{m}^{2}\right)$ and represents $44 \%$ of the total annual operating energy consumption. Room electricity is next with $\mathrm{CO}_{2}$ emissions that range from $9.3 \mathrm{CO}_{2} \mathrm{Kg} / \mathrm{m}^{2}$ in the steel building to $9.7 \mathrm{CO}_{2} \mathrm{Kg} / \mathrm{m}^{2}$ in the timber and timber-plus building, representing roughly $27 \%$ of the total annual operating $\mathrm{CO}_{2}$ emissions. The third highest end-use $\mathrm{CO}_{2}$ emissions is from cooling, ranging from $4.1 \mathrm{CO}_{2} \mathrm{Kg} / \mathrm{m}^{2}$ in the concrete building to $6.0 \mathrm{CO}_{2} \mathrm{Kg} / \mathrm{m}^{2}$ in the timber building, representing roughly $13 \%$ of 
the total annual operating $\mathrm{CO}_{2}$ emissions. Heating is the fourth highest end-use $\mathrm{CO}_{2}$ emissions, ranging from $2.5 \mathrm{CO}_{2} \mathrm{Kg} / \mathrm{m}^{2}$ in the timber building to $2.7 \mathrm{CO}_{2} \mathrm{Kg} / \mathrm{m}^{2}$ in the timber-plus building, representing $14 \%$ of the total annual operating $\mathrm{CO}_{2}$ emissions. Finally system miscellaneous represents $5 \%$ and $\mathrm{DHW} 3 \%$ of the annual total operating $\mathrm{CO}_{2}$ emissions.

From all end-uses (energy consumption and $\mathrm{CO}_{2}$ emissions) in an office building, only cooling and heating energy consumption are influenced by buildings' construction materials. Buildings' cooling and heating energy consumption are mainly determined by the building's orientation, glassed areas, heat loss capacity of the thermal envelope and by the presence or absence of a thermal mass storing and exchanging heat inside the treated areas (Donn, 2001; Fullbrook \& Jackson, 2005; Papadopoulos \& Giama, 2007; Standards New Zealand, 1982).

From all the end-uses, a building's materials are related to the heat loss capacity of the thermal envelope and the presence of a thermal mass. The energy consumed and $\mathrm{CO}_{2}$ emissions relating to the remaining end-uses such as lighting and room electricity are not determined by the building's construction materials; these are normally associated with building's architectural design.

Using air conditioning and heating mixed with natural ventilation, cooling and heating together account for only $25 \%$ to $27 \%$ of the total energy consumption in operations and $22 \%$ of the operating $\mathrm{CO}_{2}$ emissions of an office building placed in the temperate climate of New Zealand. Different performances for cooling and heating energy consumptions of the concrete, steel, timber and timber-plus buildings are due to the influence of structural components within envelope walls acting as thermal bridges, but mostly due to the amount of concrete (acting as thermal mass) used in that the buildings. The difference in the consumption between the timber and timber-plus building is due to the influence of solid wood in the partitions, external walls and ceiling in the timber-plus building acting, as a thermal mass, storing and exchanging heat (Bellamy \& Mackenzie, 2007).

When comparing the results produced in this thesis, with the end-use benchmarks proposed in Section 4.1.1.2 (table 4.4 - 4.5) BETARG (NZ) and CIBSE Guide F (UK) (Bishop, 1992; CIBSE, 2006) it was found in this thesis that for heating energy consumption both the New Zealand (49 to $67 \mathrm{kWh} / \mathrm{m}^{2} . \mathrm{yr}$ ) and the UK (79 to $201 \mathrm{kWh} / \mathrm{m}^{2} . \mathrm{yr}$ ) benchmarks are larger than the $12 \mathrm{kWh} / \mathrm{m}^{2} . \mathrm{yr}$ used in the buildings simulated in this thesis. For cooling energy consumption the results produced in this thesis $\left(11 \mathrm{kWh} / \mathrm{m}^{2} . \mathrm{yr}\right)$ are higher than the New Zealand (3 to $7 \mathrm{kWh} / \mathrm{m}^{2}$.yr) benchmark but similar to the UK (14 to $41 \mathrm{kWh} / \mathrm{m}^{2}$.yr) benchmark.

The above differences are because the benchmarks are taken from much higher total energy consumption buildings, $130 \mathrm{kWh} / \mathrm{m}^{2} . \mathrm{yr}$ in the BETARG and 133 to $568 \mathrm{kWh} / \mathrm{m}^{2} . \mathrm{yr}$ in the CIBCE benchmark. Buildings designed in this thesis have an average operating energy consumption of $85 \mathrm{kWh} / \mathrm{m}^{2} . \mathrm{yr}$ and involve natural ventilation mixed with mechanical HVAC. Since the benchmarks previously presented are not radically different, they can be used to validate the results produced in this thesis. 


\subsection{Embodied energy and $\mathrm{CO}_{2}$ emissions}

This section presents the results of the calculation of total embodied energy and total embodied $\mathrm{CO}_{2}$ emissions of the concrete, steel, timber and timber-plus building. Total embodied energy is calculated by adding initial embodied energy and recurrent embodied energy together, with the same system used for total embodied $\mathrm{CO}_{2}$ emissions. Data of embodied energy and embodied $\mathrm{CO}_{2}$ emissions is separated into the results produce using the $\mathrm{GaBi}$ and the Alcorn databases.

\subsubsection{GaBi total embodied energy and $\mathrm{CO}_{2}$ emissions}

Table 5.2 shows, for the concrete, steel, timber and timber-plus building, the total embodied energy and total embodied $\mathrm{CO}_{2}$ emissions resulting from the addition of the initial embodied energy and initial embodied $\mathrm{CO}_{2}$ emissions plus the 60 years recurrent embodied energy and recurrent embodied $\mathrm{CO}_{2}$ emissions. Data of embodied energy and embodied $\mathrm{CO}_{2}$ emissions used in table 5.2 are from the $\mathrm{GaBi}$ database.

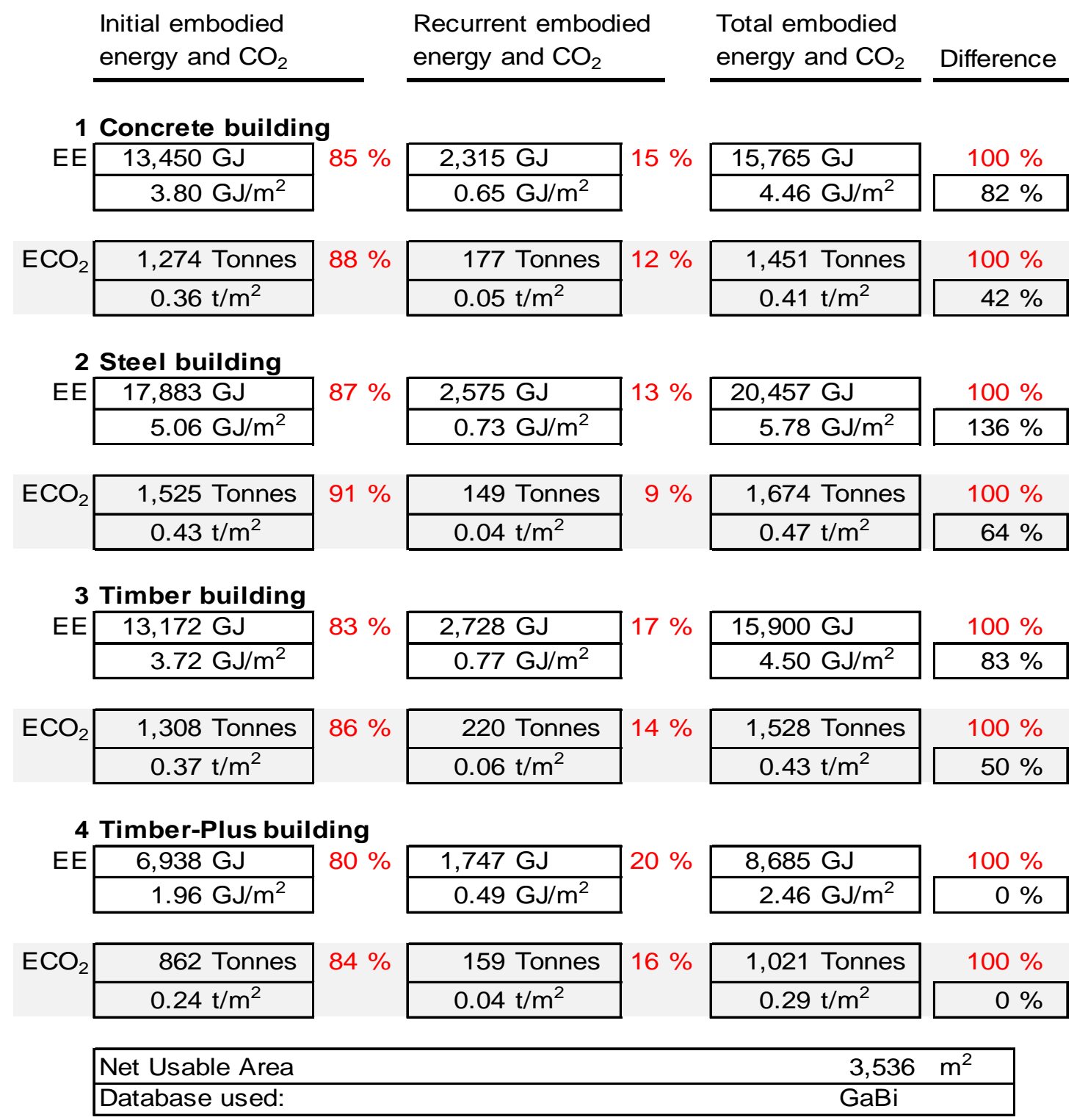

Table 5.2: Embodied energy and $\mathrm{CO}_{2}$ emissions using GaBi coefficients 
Percentages in the embodied energy (EE) and embodied $\mathrm{CO}_{2}\left(\mathrm{ECO}_{2}\right)$ rows represent the initial and recurrent embodied energy and $\mathrm{CO}_{2}$ emissions within the total embodied energy and $\mathrm{CO}_{2}$ emissions. The last column on the right side of the table shows the difference of each building's total embodied energy and $\mathrm{CO}_{2}$ against the building with the lowest outcome (Same in Table 5.3).

The results show that when $\mathrm{GaBi}$ is used for embodied energy calculation, the timber-plus building has the lowest total embodied energy with $2.46 \mathrm{GJ} / \mathrm{m}^{2}$. Differing from the Alcorn coefficients, with $\mathrm{GaBi}$, the concrete building is next lowest with $4.46 \mathrm{GJ} / \mathrm{m}^{2}$ and is followed by the timber building with $4.50 \mathrm{GJ} / \mathrm{m}^{2}$. The highest total embodied energy is in the steel building with $5.78 \mathrm{GJ} / \mathrm{m}^{2}$. The difference between the lowest and the highest total embodied energy is $3.32 \mathrm{GJ} / \mathrm{m}^{2}$.

Total embodied $\mathrm{CO}_{2}$ emissions follow a similar pattern to total embodied energy. The timber-plus building has the lowest total embodied $\mathrm{CO}_{2}$ emissions with $289 \mathrm{CO}_{2} \mathrm{Kg} / \mathrm{m}^{2}$. The concrete building is next with 410 $\mathrm{CO}_{2} \mathrm{Kg} / \mathrm{m}^{2}$, followed by the timber building with $432 \mathrm{CO}_{2} \mathrm{Kg} / \mathrm{m}^{2}$. Like with total embodied energy, the steel building has the largest total embodied $\mathrm{CO}_{2}$ emissions with $473 \mathrm{CO}_{2} \mathrm{Kg} / \mathrm{m}^{2}$. The difference between the lowest and highest $\mathrm{CO}_{2}$ emissions is $184 \mathrm{CO}_{2} \mathrm{Kg} / \mathrm{m}^{2}$. 


\subsubsection{Alcorn total embodied energy and $\mathrm{CO}_{2}$ emissions}

Table 5.3 shows. for the concrete, steel, timber and timber-plus building, the total embodied energy and total embodied $\mathrm{CO}_{2}$ emissions resulting from the addition of the initial embodied energy and initial embodied $\mathrm{CO}_{2}$ emissions, plus the 60 year recurrent embodied energy and recurrent embodied $\mathrm{CO}_{2}$ emissions. The data of the embodied energy and $\mathrm{CO}_{2}$ emissions used in Table 5.3 are from Alcorn (2003; personal communication, March 7, 2008).

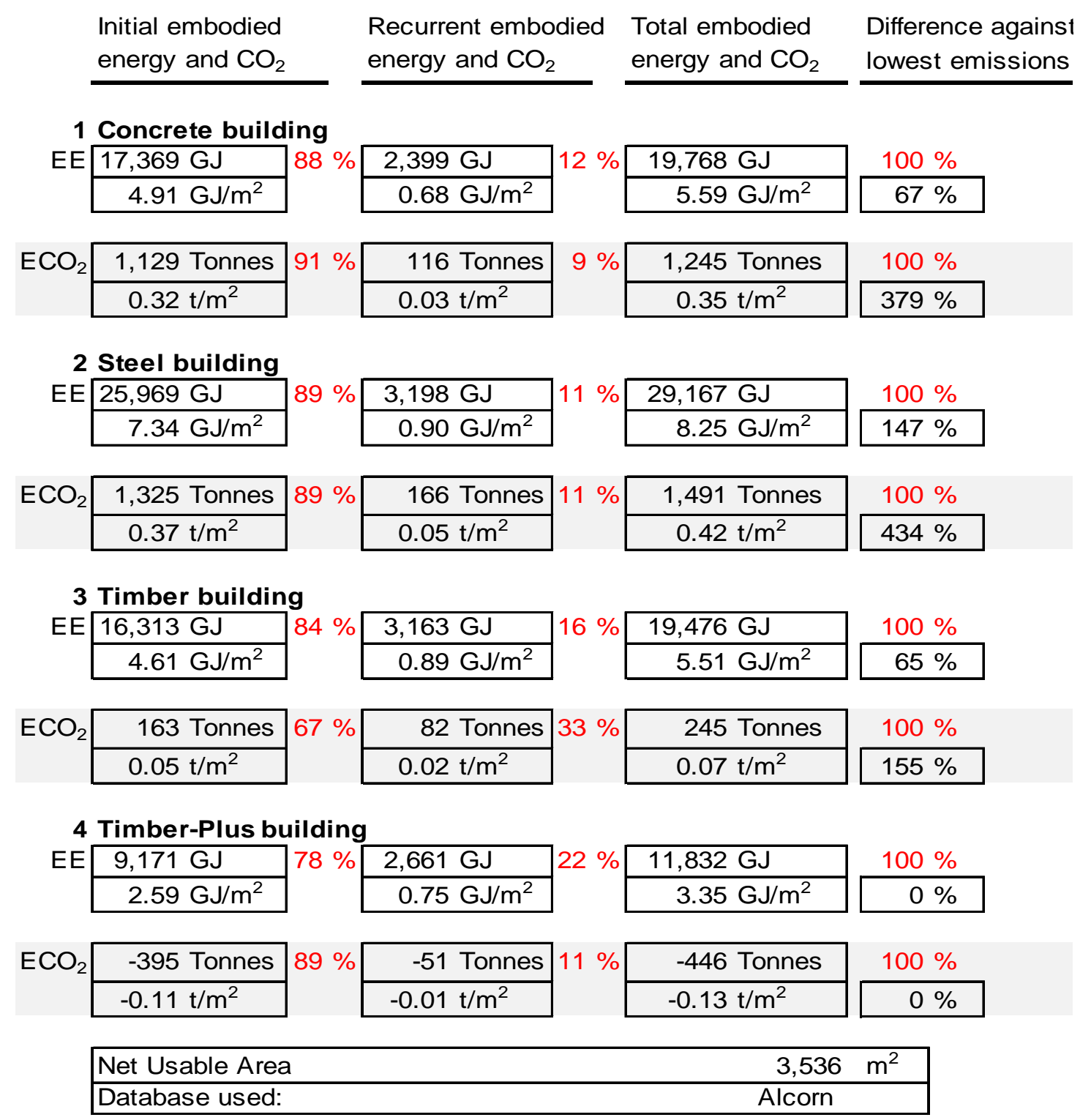

Table 5.3: Embodied energy and $\mathrm{CO}_{2}$ emissions using Alcorn coefficients.

When Alcorn is used as source of coefficients of embodied energy, the lowest total embodied energy is in the timber-plus building $\left(3.35 \mathrm{GJ} / \mathrm{m}^{2}\right)$. The timber building is next with $5.51 \mathrm{GJ} / \mathrm{m}^{2}$, followed by the concrete building with $5.59 \mathrm{GJ} / \mathrm{m}^{2}$. The highest total embodied energy is in the steel building with $8.25 \mathrm{GJ} / \mathrm{m}^{2}$. The difference between the lowest and the highest total embodied energy is $4.9 \mathrm{GJ} / \mathrm{m}^{2}$.

When looking at total embodied $\mathrm{CO}_{2}$ emissions, the differences between buildings are greater than with total embodied energy. The lowest total embodied $\mathrm{CO}_{2}$ is also the timber-plus building, with $-126 \mathrm{CO}_{2} \mathrm{Kg} / \mathrm{m}^{2}$. The 
timber building is next with $69 \mathrm{CO}_{2} \mathrm{Kg} / \mathrm{m}^{2}$, followed by the concrete building with $352 \mathrm{CO}_{2} \mathrm{Kg} / \mathrm{m}^{2}$. Like with total embodied energy, the highest total embodied $\mathrm{CO}_{2}$ emissions are in the steel building $\left(422 \mathrm{CO}_{2} \mathrm{Kg} / \mathrm{m}^{2}\right)$. The difference between the lowest and highest $\mathrm{CO}_{2}$ emissions is $548 \mathrm{CO}_{2} \mathrm{Kg} / \mathrm{m}^{2}$.

\subsubsection{Total embodied energy and $\mathrm{CO}_{2}$ emissions summary of the two different sets of coefficients}

On average, the results for embodied energy produced using the Alcorn database are higher than the results produced using the GaBi database, nevertheless both sets of results follow a similar pattern. In all cases, total embodied energy results produced using Alcorn are on average 32\% higher than results produced using $\mathrm{GaBi}$, with the with difference that range from $22 \%$ in the timber building to $43 \%$ in the steel building. The highest total embodied energy is approximately 2.4 times the total embodied energy of the timber-plus building, which has the lowest total embodied energy.

When looking at total embodied $\mathrm{CO}_{2}$ emissions there is not much similarity between the results produces by using the two different sets of coefficients. While with embodied energy Alcorn's results are on average 32\% higher than $\mathrm{GaBi}$, with embodied $\mathrm{CO}_{2}$ Alcorn's results are on average $62 \%$ lower than $\mathrm{GaBi}$.

With Alcorn coefficients the differences between building's total embodied energy are lower than the difference in building's total embodied $\mathrm{CO}_{2}$ emissions. By the other hand, with $\mathrm{GaBi}$ coefficients both embodied energy and embodied $\mathrm{CO}_{2}$ follow a similar pattern with moderated differences between buildings. Particularly with Alcorn coefficients embodied $\mathrm{CO}_{2}$ emissions, differences between buildings are significantly large. Due to negative coefficients of $\mathrm{CO}_{2}$ in timber materials, the total embodied $\mathrm{CO}_{2}$ of the timber-plus building for example is negative. Something similar happened with the timber building were if total embodied $\mathrm{CO}_{2}$ emission is positive, this is still exceptionally low compare with either the concrete or steel buildings.

It can be said that when the $\mathrm{CO}_{2}$ sequestered in timber materials is accounted, differences between buildings became significant; by the other hand when sequestration is not accounted differences are modest. For both embodied energy and $\mathrm{CO}_{2}$ emissions, the steel building is exceptionally large than any other buildings in this thesis.

For both GaBi and Alcorn results, initial embodied energy represents $84-85 \%$ and recurrent embodied energy the remaining $16-15 \%$ respectively. By the other hand, initial embodied $\mathrm{CO}_{2}$ emissions represent $87 \%$ and $84 \%$ of the total embodied $\mathrm{CO}_{2}$ emissions respectively. This is different that what was stated in Section 2.3.3 where Cole and Kernan (1995) found that for a building life of 50 years and conventional energy standards in Canada 1995 the recurring embodied energy is approximately the same as the initial embodied energy. Howard and Sutcliffe (1994) found that recurrent embodied energy might be greater than that associated with initial embodied energy.

Reasons for this discrepancy rely on the methodology use for recurrent embodied energy calculation used in this thesis. This was based in a schedule for material replacement based in materials life span (see Table B.2 in Appendix B.2). These replacements are for finishing materials and does not account for any structural 
components. Another important difference is that in Cole and Kernan (1995) and in Howard and Sutcliffe (1994), recurrent embodied energy involved refurbishment of the buildings due to change of usage or tenant. Refurbishment is not accounted in this thesis.

\subsection{Buildings component's total embodied energy and total embodied $\mathrm{CO}_{2}$ emissions}

Figure 5.3 shows the total embodied energy subdivided into five buildings components (foundations, structure, envelope, interior finishes, and windows and louvers) introduced before in Chapter 4 Section 4.1.2.2. Embodied energy calculations in this graph were produced using the Alcorn database.

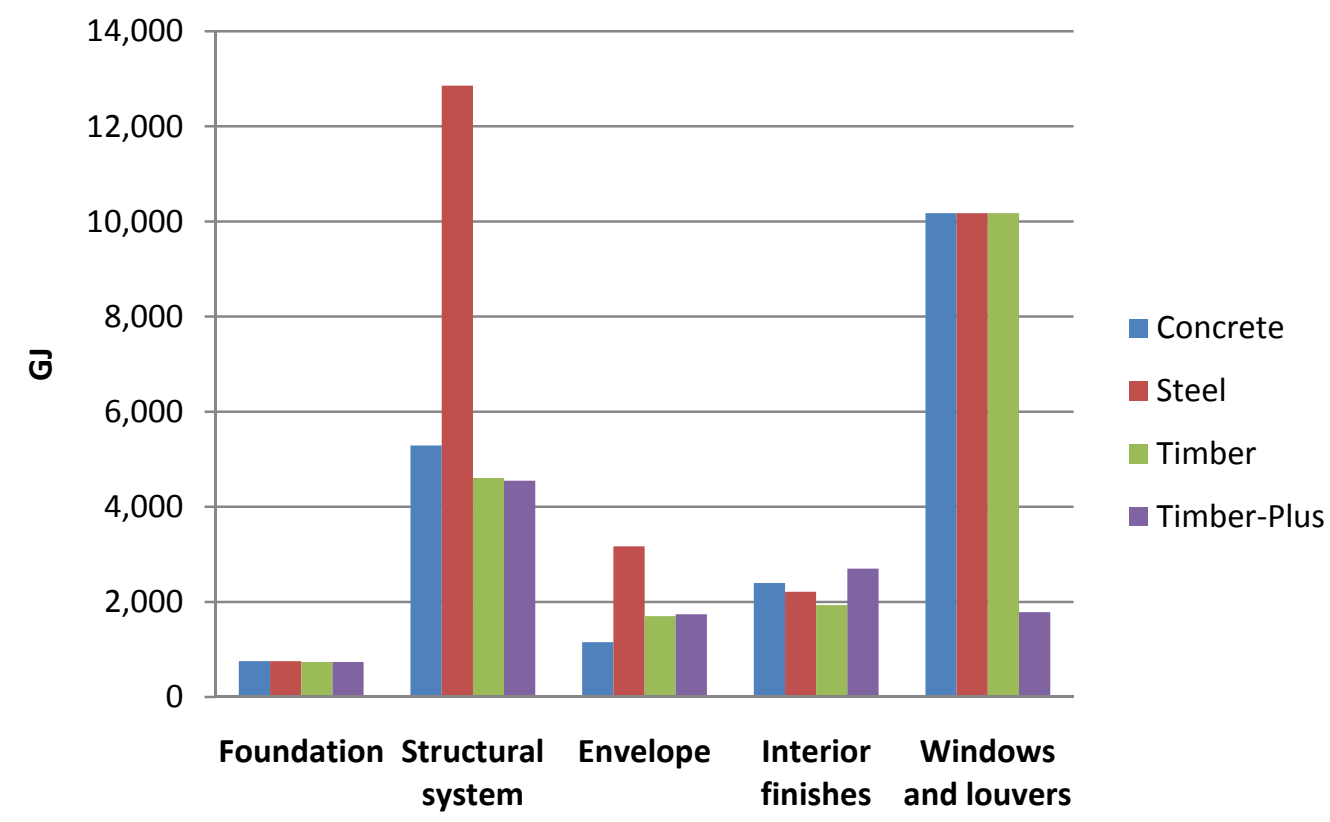

Figure 5-3: Total embodied energy segregated into five major building components for the concrete, steel, timber and timber-plus buildings (using the Alcorn database)

The highest total embodied energy contribution is from the windows and louvers, accounting for roughly $52 \%$ of the total embodied energy in the concrete and timber buildings, $35 \%$ in the steel building and only $16 \%$ in the timber-plus building (timber louvers and windows frame). The second most total embodied energy intensive component is the structural system. This is roughly $30 \%$ for the concrete, timber and timber-plus building but $44 \%$ in the steel building. Interior finishes account for roughly $10 \%$ in all cases, the envelope accounts for roughly $8 \%$ in the concrete and steel building but $12 \%$ in the timber and timber-plus buildings. Lastly foundations account for $3 \%$ to $5 \%$. 
Figure 5.4, shows the total embodied $\mathrm{CO}_{2}$ emissions subdivided into five buildings components. Embodied $\mathrm{CO}_{2}$ emissions calculations in this graph were produce using Alcorn coefficients.

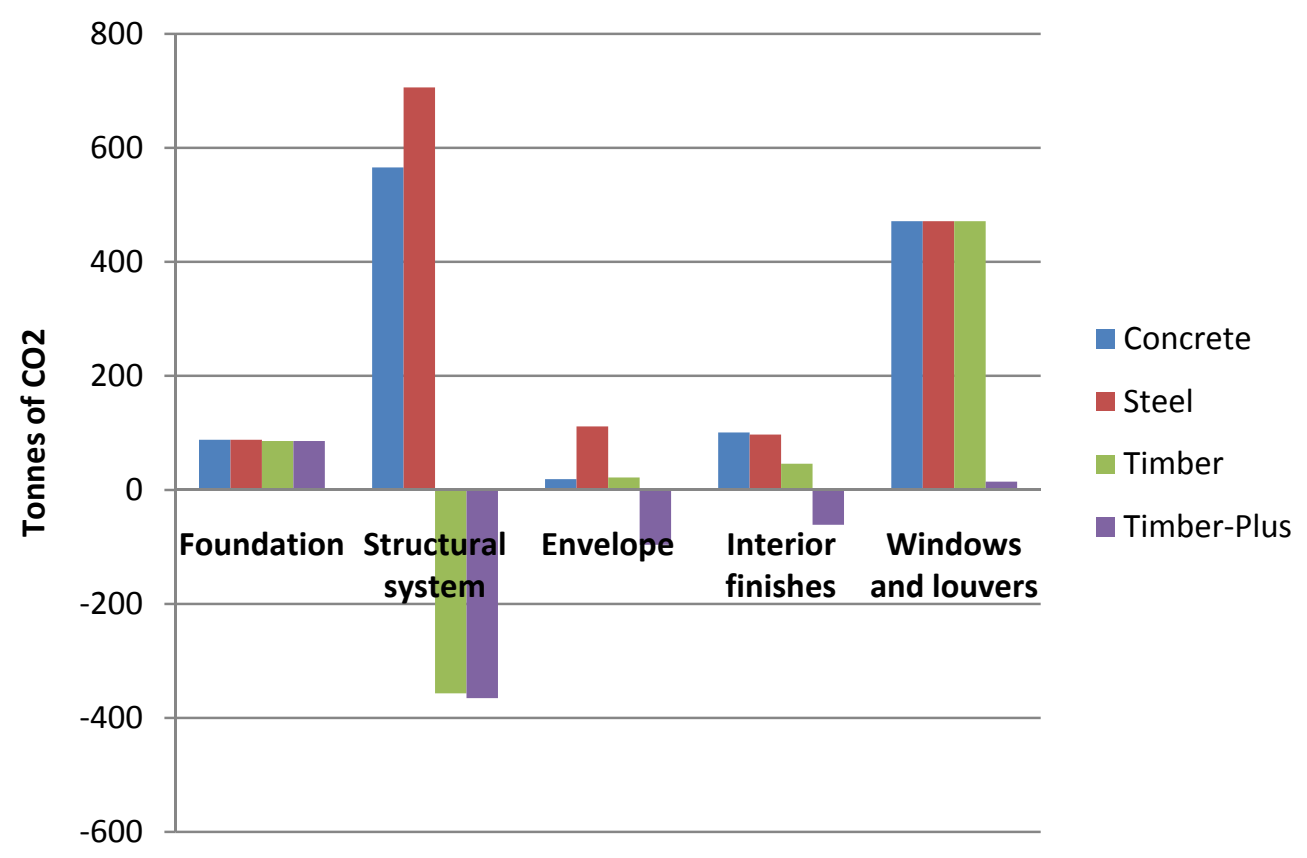

Figure 5-4: Total embodied $\mathrm{CO}_{2}$ segregated into five major building components for the concrete, steel, timber and timber-plus buildings (using Alcorn coefficients)

When looking at $\mathrm{CO}_{2}$ emissions, the structural system embodied the highest $\mathrm{CO}_{2}$ emissions of all buildings components, accounting for roughly $47 \%$ of the total embodied energy in the concrete and steel building, and $32 \%$ in the timber and timber-plus building. Both the timber and timber-plus buildings use the same structural systems, accounting for the highest embodied 'negative' emissions, being -343 and $-347 \mathrm{CO}_{2}$ tonnes respectively.

Windows and louvers is the building component responsible for the second largest initial embodied $\mathrm{CO}_{2}$ emissions representing roughly $35 \%$ of the total embodied energy for the concrete, steel and timber building. On the other hand, in the timber-plus building, the timber louvers and window frames offset almost all $\mathrm{CO}_{2}$ in that particular component, accounting for a $1 \%$ contribution to the total embodied $\mathrm{CO}_{2}$ emissions. The third largest initial $\mathrm{CO}_{2}$ emissions are for interior finishes, ranging from $4 \%$ to $8 \%$ of the total embodied energy of the four buildings, but the results are negative in the timber-plus building.

The envelope is responsible for the lowest total embodied $\mathrm{CO}_{2}$ emissions in the concrete and timber building (2\%), and $8 \%$ in the steel building,due to steel cladding and studs. The envelope accounts for $9 \%$ of the emissions of the timber-plus building, but these are negative emissions that reduce the final net total embodied $\mathrm{CO}_{2}$ emissions. Lastly foundations present no variation in all four building, representing $7 \%$ of the total embodied $\mathrm{CO}_{2}$ emissions. 


\subsubsection{Change in building components to reduce the total embodied energy and $\mathrm{CO}_{2}$}

The following section investigates a method of reducing the total embodied energy and $\mathrm{CO}_{2}$ emissions by replacing some of the buildings components used in the concrete and steel building with those used in the timber-plus building. As can be seen in Figure 5.3 and 5.4, in the timber-plus building some components (timber intensive) embodied both low energy and large negative $\mathrm{CO}_{2}$ emissions. On the other hand, some components in the concrete and steel building embodied high energy and $\mathrm{CO}_{2}$ emissions.

Since many of the buildings components are not part of the structural system, the exercise of assessing whether a potential reduction in the total embodied energy and embodied $\mathrm{CO}_{2}$, by replacing non structural related components, is possible. The assessment will take place in the concrete and steel building, by replacing some building components with those in the timber-plus building.

However, it is important to mention that the results produced by this exercise do not have the level of accuracy of the results produced in the initial study of the concrete, steel, timber and timber-plus buildings. In that initial group of buildings, changes were produced in architectural design and drawings were analysed by a quantity surveyor to calculate the amount of materials involved. Finally in that initial group of buildings, the timber-plus building was an 'improvement' of the timber building. Because of being an improvement design, in the following exercise, the timber-plus building will be compared against a concrete-timber-plus and a steel-timber-plus building.

Table 5.4 shows, for the concrete, steel and timber-plus buildings, each of the five buildings components. It is specified for each building, which components will remain as the original and which will be replaced by the components of the timber-plus building.

\begin{tabular}{|l|c|c|c|}
\multicolumn{1}{c}{ Concrete building } & Steel building & \multicolumn{1}{c|}{ Timber-Plus building } \\
\hline Foundation & Concrete & Steel & Timber \\
\hline Structure & Concrete & Steel & Timber \\
\hline Envelope & Concrete & Timber + & Timber + \\
\hline Interior finishes & Timber + & Timber + & Timber + \\
\hline $\begin{array}{l}\text { Windows } \\
\text { and louvres }\end{array}$ & Timber + & Timber + & Timber + \\
\hline
\end{tabular}

Table 5.4: Shows for the concrete, steel and timber-plus buildings, the buildings components that remain original and those that will be replaced by timber-plus building components.

In the concrete building, only windows and louvres and interior finishes were replaced. This is because all East and West façades are concrete shear walls, which are part of the structural system. Therefore a replacement of the envelope is not possible without a major transformation of the structural system. Structure will remain untouched in all cases as well as foundations. In the steel building, the structural system allows replacement of the envelope, interior finishes and the windows and louvers. 
Figure 5.5 shows the results of embodied energy produced by the replacement of buildings components suggested in Table 5.4. After the replacements, the concrete building is recognised as the concrete (timberplus) building and the steel building as steel (timber-plus). The timber-plus building replaces the timber building.

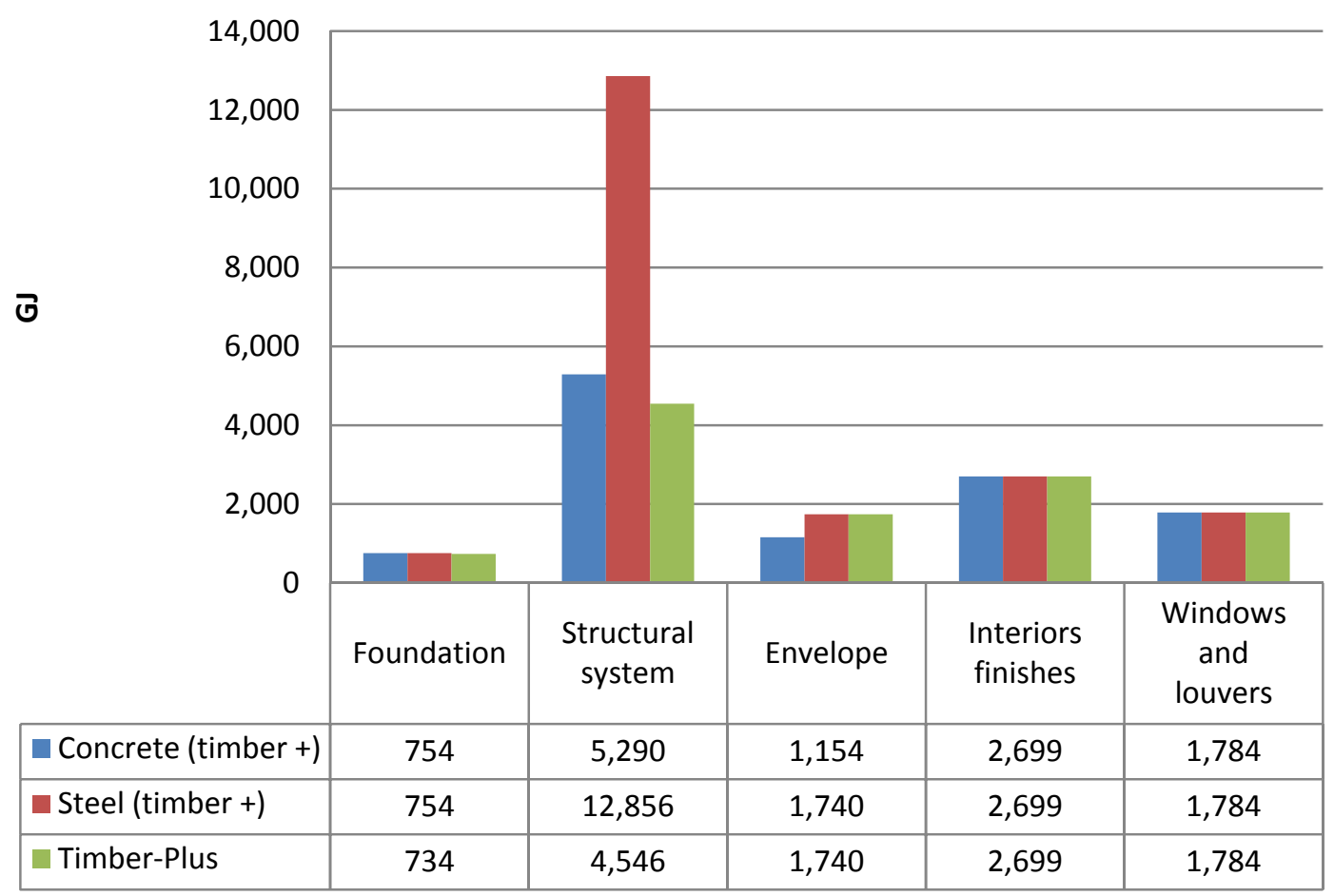

Figure 5-5: Concrete, steel and timber buildings using timber components total embodied energy (Alcorn coefficients)

It can be seen that the highest embodied energy is in the structural system, ranging from $4,546 \mathrm{GJ}$ to 12,856 GJ of the total initial embodied energy in the timber-plus and steel building respectively. Interior finishes are the second highest embodied energy building component and is 2,699 $\mathrm{GJ}$ in all cases. Interior finishes in the initial buildings were 1,932 and 2,699 GJ in the timber and timber-plus building respectively. Timber-plus interior finishes do not decrease the total embodied energy of the concrete and steel building, as a matter of fact this component in the timber-plus building is the most energy intensive of all buildings.

Windows and louvres are no longer an energy crucial component and after replacement undertaken in this exercise these account for only 1,784 GJ in all cases. Specifically, this component added 10,174 GJ to the original buildings and is the second highest total embodied energy component for the concrete, steel and timber buildings. The replacement of aluminium windows and louvres with cedar louvres and composite aluminium-cedar windows saves about 8,390 GJ of embodied energy. Finally, the envelope now accounts for 1,154 and 1,740 GJ in the concrete and timber-plus buildings respectively. Due to the replacement of this component, important initial embodied energy reductions for the steel building are made, of about 1,428 GJ from the initial total of $3,168 \mathrm{GJ}$. 
Figure 5.6 shows the total embodied energy of the initial cases against the cases with component replacement. In other words, Figure 5.6 shows the total embodied energy of the concrete, steel and timber buildings compared against the total embodied energy of the concrete (timber-plus), the steel (timber-plus) and the timber-plus buildings.

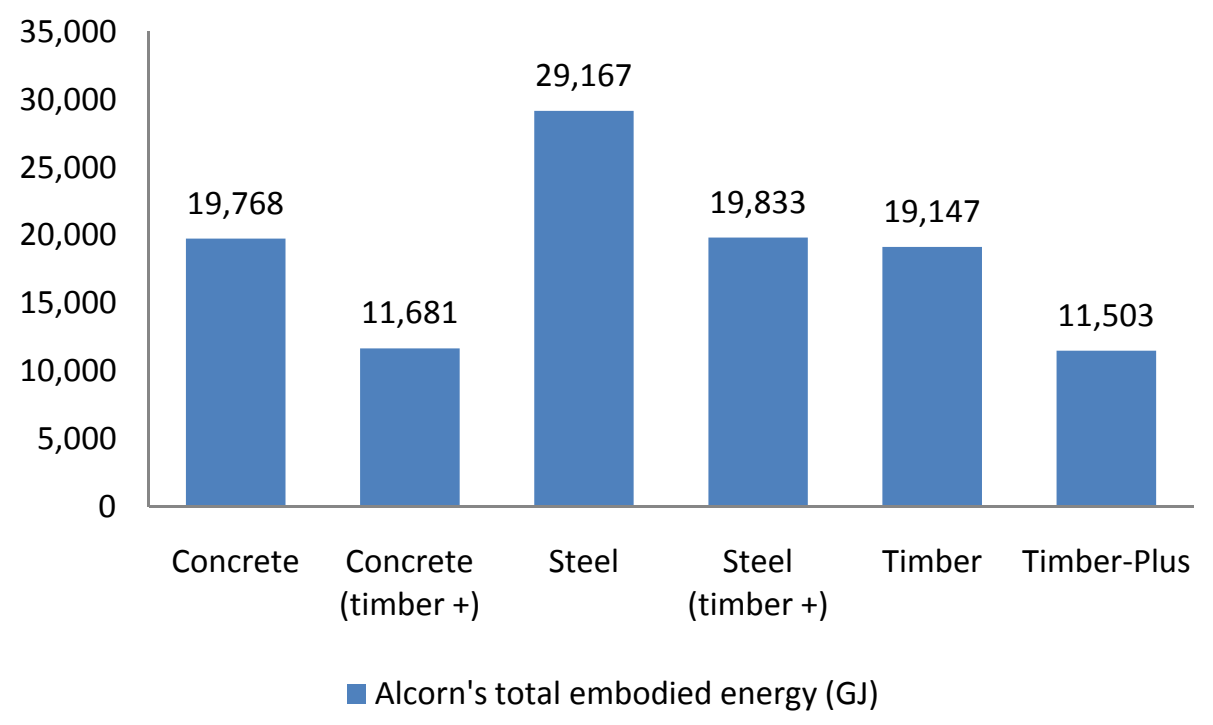

Figure 5-6: The total embodied energy of the initial cases compared against the total embodied energy of the cases with component replacement.

With the replacements mentioned in Table 5.4, the concrete building has a reduction of 8,087 GJ, which represents a $41 \%$ reduction of total embodied energy. The steel building has a reduction of $9,334 \mathrm{GJ}$, which is a $32 \%$ reduction and the timber building has a reduction of $7,644 \mathrm{GJ}$, which represents a $40 \%$ reduction. These major reductions are due to the replacement of all aluminium parts in the windows and louvers components with timber parts. There is an average $38 \%$ reduction in all cases due to the replacement of high embodied energy parts by timber parts. 
Figure 5.7 shows the results of embodied $\mathrm{CO}_{2}$ produced by the replacement of building components suggested in Table 5.4 .

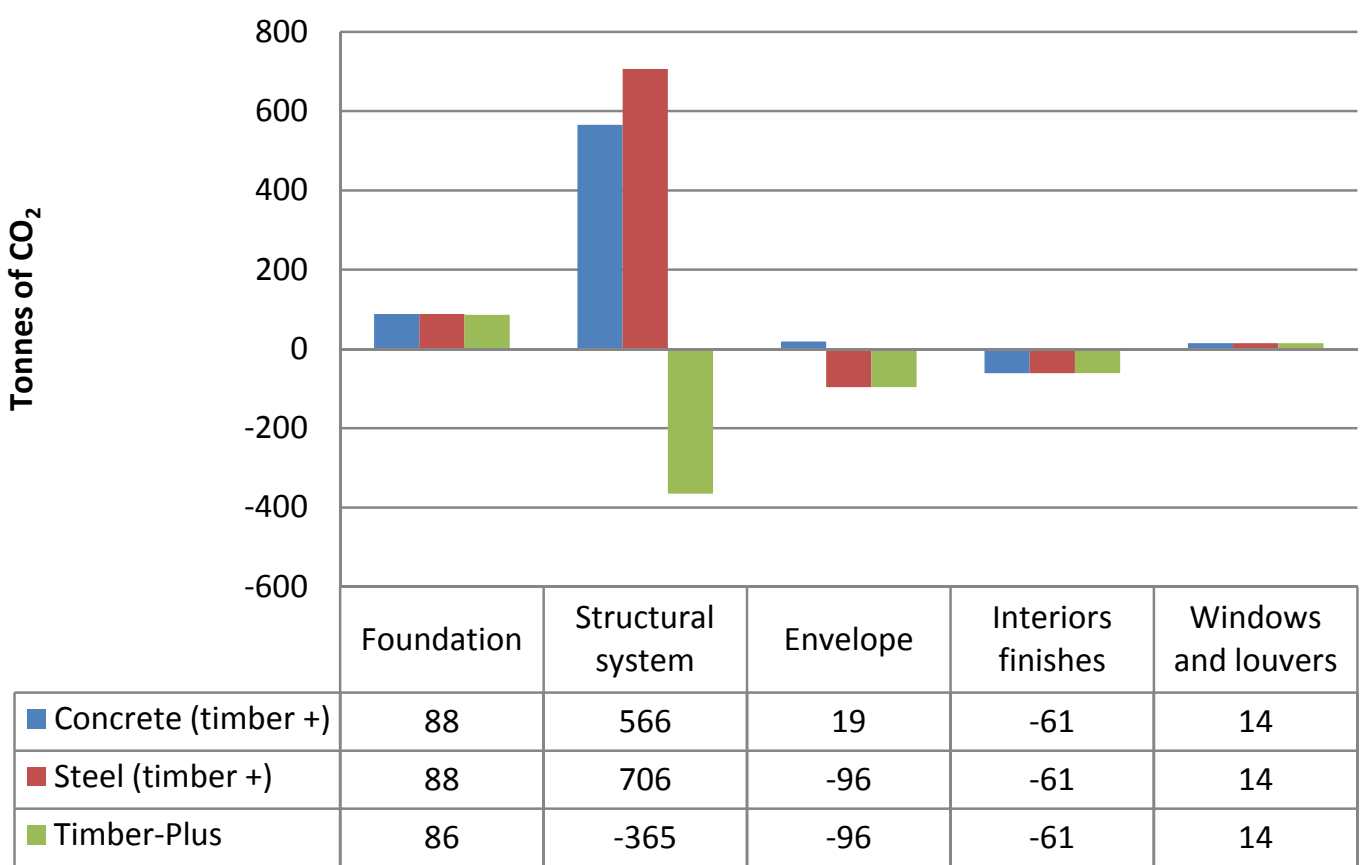

Figure 5-7: Total embodied $\mathrm{CO}_{2}$ of the concrete, steel and timber buildings that are using timber components (Alcorn coefficients).

It can be seen that the highest embodied $\mathrm{CO}_{2}$ emissions in the figure above is for the steel and concrete buildings' structural system, embodying 706 and $566 \mathrm{CO}_{2}$ tonnes respectively. The rest of the components embodied very low (maximum of $88 \mathrm{CO}_{2}$ tonnes) or even negative $\mathrm{CO}_{2}$ emissions. The timber building's structural system embodied a total of $-365 \mathrm{CO}_{2}$ tonnes. Compared with the concrete, steel and timber building interior finishes have now an embodied negative $\mathrm{CO}_{2}$ emission of -60 tonnes, where before, this component had embodied $\mathrm{CO}_{2}$ emissions of up to 100 tonnes in the initial concrete building, for example. The envelope remains the same for the concrete building but for the steel building this decreases from 111 tonnes of embodied $\mathrm{CO}_{2}$ emissions to -96 tonnes of $\mathrm{CO}_{2}$. Finally, the windows and louvres have negligible embodied emissions of $14 \mathrm{CO}_{2}$ tonnes. These components decrease significantly from $471 \mathrm{CO}_{2}$ tonnes in all original buildings. The embodied $\mathrm{CO}_{2}$ emissions remain the same for the foundations. 
Figure 5.8 shows the total embodied $\mathrm{CO}_{2}$ emissions of the concrete, steel and timber buildings compared against the total embodied $\mathrm{CO}_{2}$ emissions of the concrete (timber-plus), the steel (timber-plus) and the timber-plus buildings. Buildings are shown before and after their components are replaced.

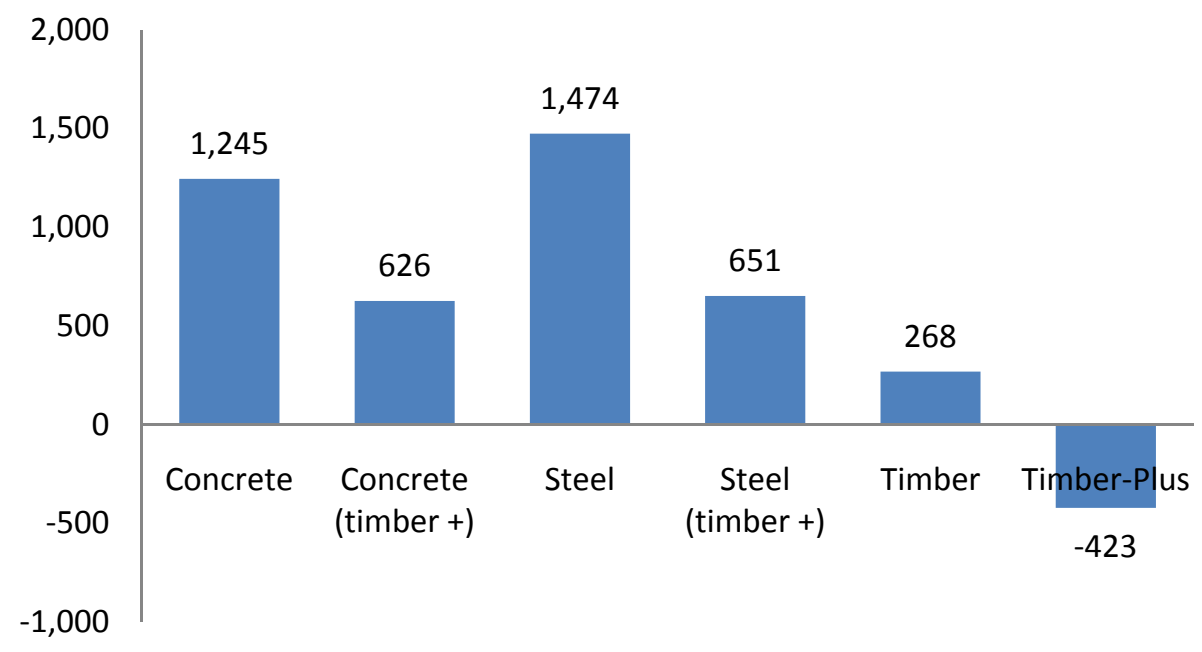

Alcorn's total embodied $\mathrm{CO} 2$ emissions (CO2 tonnes)

Figure 5-8: The total embodied $\mathrm{CO}_{2}$ emissions of the initial cases compared against the total embodied $\mathrm{CO}_{2}$ emissions of the cases with component replacement.

With the replacements mentioned in Table 5.4, the concrete building has a reduction of $619 \mathrm{CO}_{2}$ tonnes, which represents $50 \%$ of the total embodied energy reduction. The steel building has a reduction of $823 \mathrm{CO}_{2}$ tonnes, which is a 56\% reduction, and the timber building has a reduction of $691 \mathrm{CO}_{2}$ tonnes, which represents a $158 \%$ reduction. Similar to Figure 5.6, the major reductions are due to the replacement of all aluminium parts in the windows and louvres with timber parts. There is an average $53 \%$ reduction for the concrete and steel buildings, and a 158\% reduction in the timber building. An increase impact of replacement is due to large amount of $\mathrm{CO}_{2}$ sequestered in the timber components added to the building in replacement of components with high embodied $\mathrm{CO}_{2}$ emissions.

It was observed that the use of timber (when $\mathrm{CO}_{2}$ sequestration is accounted for) within a building's fabric helps to offset embodied $\mathrm{CO}_{2}$ emissions of other materials such as concrete or steel.

If in the concrete building, the windows and louvers and interior finishes and in the steel building, the envelope, interior finishes and windows and louvers were replaced by the same components used in the timber-plus building, then the concrete and steel buildings would potentially have a reduction of $41 \%$ and $32 \%$ of their total embodied energy respectively. When looking at $\mathrm{CO}_{2}$ emissions, replacing the items mentioned above, the concrete and steel buildings would potentially experience a reduction of $50 \%$ and $56 \%$ of their total embodied $\mathrm{CO}_{2}$ emissions respectively.

When designing a building, the decision to use a certain structural system, windows, frames or louver materials can radically determine the total embodied $\mathrm{CO}_{2}$ emissions of the building. The use of steel is likely to increase the embodied energy and $\mathrm{CO}_{2}$ emissions while the use of timber based materials create the 
opposite effect by offsetting $\mathrm{CO}_{2}$ emissions. Architectural components (not part of a buildings primary or secondary structure) can be responsible for a very high proportion of the embodied $\mathrm{CO}_{2}$ emissions. For example, the choice of windows and louvers can account for up to $38 \%$ of total embodied $\mathrm{CO}_{2}$ emissions, and the envelope can account for roughly $8 \%$ of total embodied $\mathrm{CO}_{2}$ emissions. 


\subsection{Total life-cycle energy consumption and $\mathrm{CO}_{2}$ emissions}

This section will discuss the total life-cycle energy consumption and $\mathrm{CO}_{2}$ emissions of each of the four buildings. Life-cycle energy consumption is calculated by adding the operating energy consumption to the total embodied energy. Life-cycle $\mathrm{CO}_{2}$ emissions are calculated by adding the operating $\mathrm{CO}_{2}$ emissions to the total embodied $\mathrm{CO}_{2}$ emissions. Embodied energy and embodied $\mathrm{CO}_{2}$ emissions are calculated using both the Alcorn and $\mathrm{GaBi}$ databases and this section is separated into the results produced by using each of the databases.

Figure 5.9 shows the total life-cycle energy consumption segregated into initial embodied energy, recurrent embodied energy and the operating energy for the concrete, steel, timber and timber-plus buildings. For each building, the results presented are produced using both the Alcorn and GaBi coefficients.

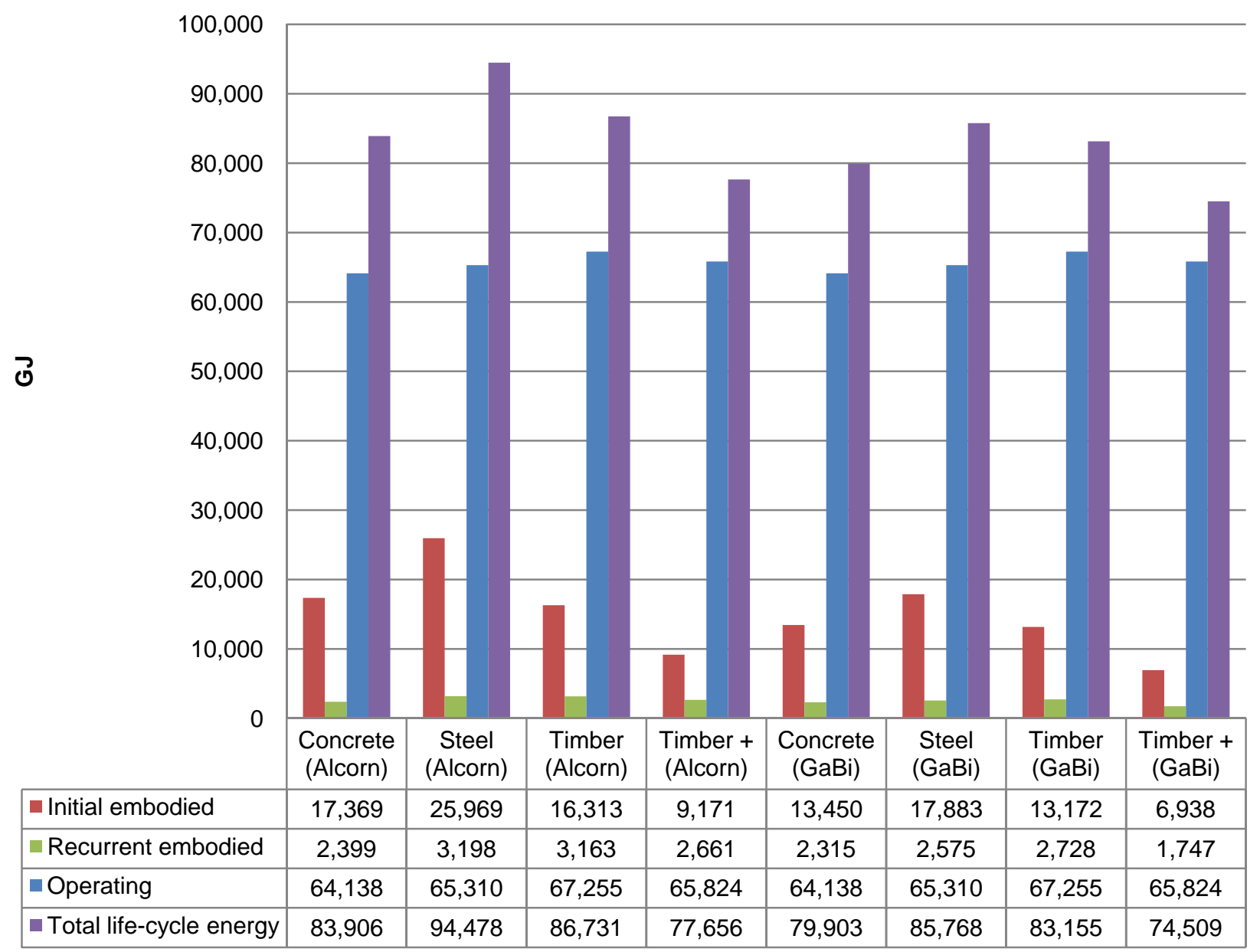

Figure 5-9: Summary of the life-cycle energy consumption of the four buildings using Alcorn and GaBi coefficients for the initial and recurrent embodied energy calculation. 
Figure 5.10 shows the total life-cycle $\mathrm{CO}_{2}$ emissions segregated into initial embodied $\mathrm{CO}_{2}$, recurrent embodied $\mathrm{CO}_{2}$ and the operating $\mathrm{CO}_{2}$ emissions. For each building, the results presented are produced using both the Alcorn and $\mathrm{GaBi}$ coefficients.

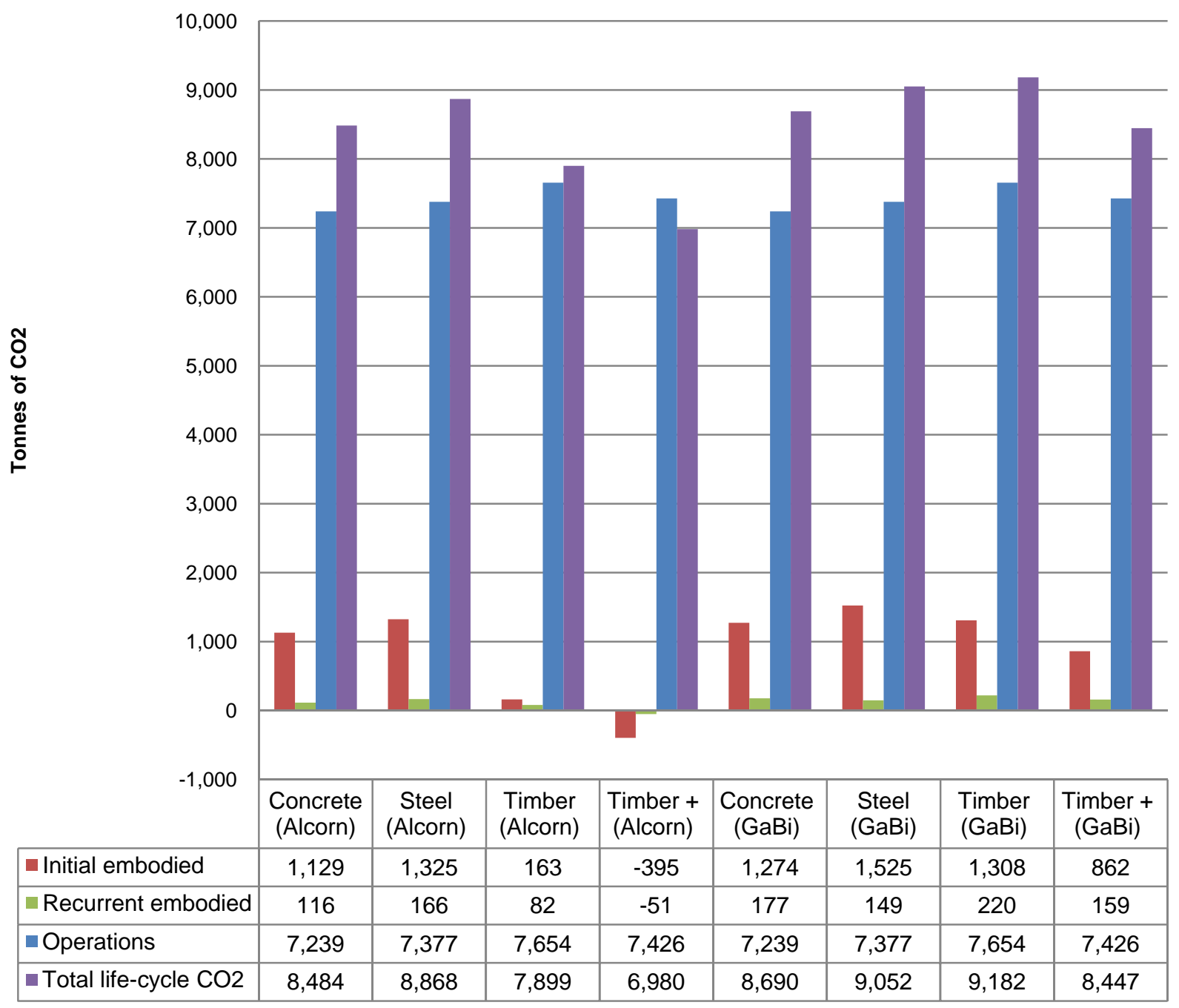

Figure 5-10: Summary of the life-cycle $\mathrm{CO}_{2}$ emissions of the four buildings using Alcorn and GaBi coefficients for initial and recurrent embodied $\mathrm{CO}_{2}$ calculation. 


\subsubsection{Alcorn life-cycle energy consumption and $\mathrm{CO}_{2}$ emissions}

When using the Alcorn database for the total embodied energy calculation, the 60 years of operating energy consumption ranges from $69 \%$ of the total life-cycle energy consumption in the steel building to $85 \%$ in the timber-plus building, with an average of $77 \%$ over the four buildings. The total embodied energy ranges from $15 \%$ in the timber-plus building to $31 \%$ in the steel building, averaging $23 \%$ over the four buildings.

When looking at life-cycle $\mathrm{CO}_{2}$ emissions, the 60 year operating $\mathrm{CO}_{2}$ emissions range from $83 \%$ for the steel building to $106 \%$ for the timber-plus building (due to negative embodied $\mathrm{CO}_{2}$ emissions) with an average of $93 \%$ over the four buildings. The total embodied $\mathrm{CO}_{2}$ emissions range from $-6 \%$ in the timber-plus building to $17 \%$ in the steel building, with an average of $7 \%$ over the four buildings.

The lowest life-cycle energy consumption is in the timber-plus building $\left(22.0 \mathrm{GJ} / \mathrm{m}^{2}\right)$, and the highest in the steel building $\left(26.7 \mathrm{GJ} / \mathrm{m}^{2}\right)$. The concrete building has the second best performance $\left(23.7 \mathrm{GJ} / \mathrm{m}^{2}\right)$ and the timber building the third $\left(24.5 \mathrm{GJ} / \mathrm{m}^{2}\right)$.

When looking at life-cycle $\mathrm{CO}_{2}$ emissions the trend changes when compared with life-cycle energy consumption. The timber-plus and steel buildings have the lowest $\left(1.97 \mathrm{t} / \mathrm{m}^{2}\right)$ and highest $\left(2.51 \mathrm{t} / \mathrm{m}^{2}\right)$ lifecycle $\mathrm{CO}_{2}$ emissions respectively. The change in the trend is because the timber building $\left(2.23 \mathrm{t} / \mathrm{m}^{2}\right)$ improves and is placed as the second lowest $\mathrm{CO}_{2}$ emitter and the concrete building $\left(2.4 \mathrm{t} / \mathrm{m}^{2}\right)$ is placed just after the timber building, in third place. The difference between the highest (steel building) and lowest (timber-plus building) life-cycle energy consumption and $\mathrm{CO}_{2}$ emissions represent a $22 \%$ and $27 \%$ increment between the highest and the lowest respectively (see Table D.1 and D.2 in appendix D.1).

\subsubsection{GaBi life-cycle energy consumption and $\mathrm{CO}_{2}$ emissions}

When $\mathrm{GaBi}$ coefficients are used for total embodied energy calculation, differences in the total life-cycle energy consumption of the four buildings are less significant than when Alcorn coefficients are used.

When using $\mathrm{GaBi}$ coefficients, the 60 year operating energy consumption ranges from $76 \%$ of the total lifecycle energy consumption in the steel building to $88 \%$ in the timber-plus building and averages $81 \%$ over the four buildings. The total embodied energy ranges from $12 \%$ in the timber-plus building to $24 \%$ in the steel building, averaging $19 \%$ over the four buildings.

When looking at life-cycle $\mathrm{CO}_{2}$ emissions, 60 year operating $\mathrm{CO}_{2}$ emissions range from $82 \%$ for the steel building to $88 \%$ for the timber-plus building with an average of $84 \%$ over the four buildings. The total embodied $\mathrm{CO}_{2}$ emissions range from $12 \%$ in the timber-plus building to $18 \%$ in the steel building with an average of $16 \%$ over the four buildings. 
The lowest life-cycle energy consumer is the timber-plus building $\left(21.1 \mathrm{GJ} / \mathrm{m}^{2}\right)$ and the highest is the steel building $\left(24.3 \mathrm{GJ} / \mathrm{m}^{2}\right)$. The concrete building $\left(22.6 \mathrm{GJ} / \mathrm{m}^{2}\right)$ has the second best performance and the timber building $\left(23.5 \mathrm{GJ} / \mathrm{m}^{2}\right)$ the third.

When looking at life-cycle $\mathrm{CO}_{2}$ emissions, the trend changes compared with life-cycle energy consumption. The timber-plus and timber buildings have the lowest $\left(2.39 \mathrm{t} / \mathrm{m}^{2}\right)$ and highest $\left(2.60 \mathrm{t} / \mathrm{m}^{2}\right)$ life-cycle $\mathrm{CO}_{2}$ emissions respectively. The concrete building $\left(2.46 \mathrm{t} / \mathrm{m}^{2}\right)$ is the second lowest life-cycle $\mathrm{CO}_{2}$ emitter and the steel building $\left(2.56 \mathrm{t} / \mathrm{m}^{2}\right)$ is placed just before the timber building (highest life-cycle $\mathrm{CO}_{2}$ emissions).

The difference between the lowest and the highest life-cycle energy consumption represents a $15 \%$ increment of the highest over the lowest. On the other hand the difference between the lowest and the highest life-cycle $\mathrm{CO}_{2}$ emissions represents a 9\% increment of the highest over the lowest (see Table D.1 and D.2 in appendix D.1).

\subsubsection{Summary of the life-cycle energy consumption and $\mathrm{CO}_{2}$ emissions}

The energy results of the thesis show that when using the Alcorn database, the total embodied energy averaged $23 \%$ and operating energy consumption averaged $77 \%$ of the total life-cycle energy consumption for the four buildings. Using the GaBi coefficients, total embodied energy averaged $19 \%$ and operating energy consumption averaged $81 \%$ of the total life-cycle energy consumption of the four buildings.

Using the Alcorn database, the difference between the highest (steel building) and lowest (timber-plus building) life-cycle energy consumption represents a 22\% increment between the two. Using the GaBi database, the difference between the highest (timber building) and the lowest (timber-plus building) life-cycle energy consumption represents a $15 \%$ increment between the two.

In the $\mathrm{CO}_{2}$ emissions results, when using the Alcorn coefficients, the total embodied $\mathrm{CO}_{2}$ emissions averaged $7 \%$ and operating $\mathrm{CO}_{2}$ emissions averaged $93 \%$. Using the $\mathrm{GaBi}$ coefficients, total embodied $\mathrm{CO}_{2}$ emissions averaged $16 \%$ and operating $\mathrm{CO}_{2}$ emissions average $84 \%$ of the life-cycle $\mathrm{CO}_{2}$ emissions of the four buildings.

Using the Alcorn coefficients, the difference between the highest (steel building) and lowest (timber-plus building) life-cycle $\mathrm{CO}_{2}$ emissions represents a $27 \%$ increment between the two. Using the GaBi coefficients, the difference between the highest (timber building) and the lowest (timber-plus building) life-cycle $\mathrm{CO}_{2}$ emissions represents a $9 \%$ increment between two.

As for the case of embodied energy, the Alcorn results averaged 32\% higher than the GaBi results and in the case of embodied $\mathrm{CO}_{2}$ the Alcorn results averaged $62 \%$ lower than the GaBi results. Embodied energy can significantly influence the life-cycle energy consumption and $\mathrm{CO}_{2}$ emissions of contemporary low energy buildings. Using the Alcorn database, the steel building embodied the equivalent of 27 years of operating energy consumption and 12 years of operating $\mathrm{CO}_{2}$ emissions. At the other end of the spectrum, the timber- 
Discussion

plus building embodied the equivalent of 11 years of operating energy consumption and has stored the equivalent of 3.6 years of operating $\mathrm{CO}_{2}$ emissions.

Using the $\mathrm{GaBi}$ database, the steel building embodied the equivalent of 19 years of operating energy consumption and 14 years of operating $\mathrm{CO}_{2}$ emissions, while the timber-plus building embodied the equivalent of 8 years of operating energy consumption and 8 years of operating $\mathrm{CO}_{2}$ emissions.

These findings are of significance in the assessment of the embodied energy and embodied $\mathrm{CO}_{2}$ components of building sustainability rating tools. 
Discussion 


\section{Conclusions}

This thesis describes the influence of construction materials on the life cycle energy use and carbon dioxide emissions of medium sized commercial buildings. When describing buildings by materials, there is a tendency to label according to the main material used, however, the vast majority of commercial buildings use a large number of materials. Hence it is not clear which materials or combinations of materials can achieve the best performance, in terms of life-cycle energy use and carbon dioxide emissions.

In order to develop a set of 'benchmarks', this research modelled the performance of three similar medium sized commercial buildings, located in the temperate climate of New Zealand, each designed using primarily concrete, steel or wood.

The model was based on an actual six-storey $4250 \mathrm{~m}^{2}$ floor area building, with a mixed-mode ventilation system, currently under construction at University of Canterbury in Christchurch. While the actual building is being constructed in concrete, two alternative versions have been designed in which the structures and finishes are predominantly steel and wood. These three are referred to as the concrete, steel and timber buildings, respectively. A fourth building design is the timber-plus building which has a timber structure and uses timber wherever possible in linings, window frames, louvres and cladding.

The analysis of each case study includes the calculation of embodied energy and embodied carbon dioxide. The whole life-cycle operational energy used and carbon dioxide emitted in the operation of the buildings was simulated using DesignBuilder software.

The embodied energy and $\mathrm{CO}_{2}$ emissions were obtained using two different methods, which were compared. In the "Alcorn" method, the quantities of materials in each building were multiplied by New Zealand embodied energy and embodied $\mathrm{CO}_{2}$ coefficients. In the "GaBi" method, the embodied energy and embodied $\mathrm{CO}_{2}$ emissions were obtained from the GaBi LCA software, largely based on European materials. As well as differences in the relevant coefficients, the two methods used different approaches in relation to the calculation of the $\mathrm{CO}_{2}$ sequestration of timber materials. 
The aim of this thesis was to determine the influence of construction materials on the life cycle energy use and $\mathrm{CO}_{2}$ emissions of medium sized commercial buildings, using the four different buildings designs. A secondary aim was to identify how the use of different sets of embodied energy and $\mathrm{CO}_{2}$ coefficients influences the outcome.

This thesis will answer the following questions:

1. Can concrete, steel, timber and timber-plus buildings be designed to have (similar) low operating energy consumption?

2. What is the influence of construction materials on operating $\mathrm{CO}_{2}$ emissions?

3. What is the influence of construction materials on the embodied energy in a building?

4. What is the influence of construction materials on embodied $\mathrm{CO}_{2}$ emissions?

5. What is the influence of construction materials on the relative proportion of embodied energy to total life-cycle energy consumption?

6. What is the influence of construction materials on the relative proportion of embodied $\mathrm{CO}_{2}$ emissions to total life-cycle $\mathrm{CO}_{2}$ emissions?

7. How does the choice of finishing materials affect the life-cycle energy use and $\mathrm{CO}_{2}$ emissions?

8. How does the use of different sets of embodied energy and embodied $\mathrm{CO}_{2}$ coefficients influence the answer to all previous questions?

The answers to the research questions are as follows: 


\section{Can concrete, steel, timber and timber-plus buildings be designed to have (similar) low operating energy consumption?}

The operating energy analysis in this thesis showed that concrete, steel, timber and timber-plus buildings can all be easily designed to have low operating energy consumption ( $85 \mathrm{kWh} / \mathrm{m}^{2} . \mathrm{yr}$ ). There were no major differences between the concrete, steel or timber buildings. Even lower operational energy consumption could be achieved by using increasing amounts of insulation and thermal mass and by better lighting design and better choice of office equipments in each of the buildings. Concrete is the traditional material used for thermal mass, but thermal mass can also be provided in the timber buildings or in the steel building by using exposed wood surfaces as thermal mass, or by using Phase Change Materials in the wall and ceiling linings.

Even though the total operational energy consumption is similar in all buildings, the relative amounts of energy used for heating and cooling can be very different, depending on the different thermal envelopes and the relative amount of thermal mass in each building.

In the actual case study buildings described in this thesis, the annual operating energy of each of the four case study buildings is within 5\% of each other. In other words, the concrete building uses 5\% (14,432 kWh) less annual operating energy than the timber building with the higher operating energy consumption. The annual operating energy consumption of the four case study buildings are presented in the table 6.1 below.

\begin{tabular}{|r|r|}
\hline \multicolumn{2}{|c|}{ Annual operating energy consumption } \\
\hline Concrete building & $296,935.0 \mathrm{kWh}$ \\
\hline Steel building & $302,363.1 \mathrm{kWh}$ \\
\hline Timber building & $311,367.0 \mathrm{kWh}$ \\
\hline Timber-Plus building & $304,740.3 \mathrm{kWh}$ \\
\hline
\end{tabular}

Table 6.1: Case study buildings, annual operating energy.

For all of the low energy buildings described in this thesis, only $25 \%$ of the energy consumption is for heating and cooling while $75 \%$ is for lighting, room electricity, system miscellaneous energy and domestic hot water. 


\section{What is the influence of construction materials on operating $\mathrm{CO}_{2}$ emissions?}

The trends for operating energy consumption are also reflected in the operating $\mathrm{CO}_{2}$ emissions. The actual numbers are slightly different because the conversion from energy to $\mathrm{CO}_{2}$ emissions depends on the energy mix, and the manufacturing of some materials results in chemical emissions of $\mathrm{CO}_{2}$ which are not directly related to energy use. In the operating energy analysis, for example, energy for cooling is electricity and energy for heating is LPG, consequently different $\mathrm{CO}_{2}$ coefficients are applied so that the energy and $\mathrm{CO}_{2}$ analyses give slightly different answers. If the annual operating energy consumption of each of the four case study buildings is within $5 \%$ of each other, the operating $\mathrm{CO}_{2}$ emissions is $6 \%$ of each other.

The annual operating $\mathrm{CO}_{2}$ emissions of the four case study buildings are presented in the table 6.2 below.

\begin{tabular}{|r|r|}
\hline Annual operating $\mathrm{CO}_{\mathbf{2}}$ emissions \\
\hline Concrete building & $120.7 \mathrm{t} \mathrm{CO}_{2}$ \\
\hline Steel building & $123.0 \mathrm{t} \mathrm{CO}_{2}$ \\
\hline Timber building & $127.6 \mathrm{t} \mathrm{CO}_{2}$ \\
\hline Timber-Plus building & $123.8 \mathrm{t} \mathrm{CO}_{2}$ \\
\hline
\end{tabular}

Table 6.2: Case study buildings, annual operating $\mathrm{CO}_{2}$ emissions.

\section{What is the influence of construction materials on embodied energy in buildings?}

The total embodied energy is about equal in the concrete and timber buildings, it is $20 \%$ to $30 \%$ more in the steel building (depending on the data used), $40 \%$ lower in the timber-plus building due to the much larger amount of wood in that building. The embodied energy of the four case study buildings are presented in the table 6.3 below.

\begin{tabular}{|r|l|r|}
\hline Total embodied energy & Alcorn & GaBi \\
\hline Concrete building & $19,768.3 \mathrm{kWh}$ & $15,764.9 \mathrm{kWh}$ \\
\hline Steel building & $29,167.2 \mathrm{kWh}$ & $20,457.5 \mathrm{kWh}$ \\
\hline Timber building & $19,475.7 \mathrm{kWh}$ & $15,899.9 \mathrm{kWh}$ \\
\hline Timber-Plus building & $11,832.4 \mathrm{kWh}$ & $8,685.3 \mathrm{kWh}$ \\
\hline
\end{tabular}

Table 6.3: Case study buildings, total embodied energy.

It was also observed that in most cases the recurrent embodied energy (energy for maintenance) is $15 \%$ to $20 \%$ of the total embodied energy (recurrent + initial). 


\section{What is the influence of construction materials on embodied $\mathrm{CO}_{2}$ emissions in buildings?}

If we allow for the effect of carbon sequestration (Alcorn data), the influence of construction materials on the embodied $\mathrm{CO}_{2}$ emissions of the steel building are $20 \%$ more than those from the concrete building. The embodied $\mathrm{CO}_{2}$ emissions from the timber building are only $15 \%$ of those from the concrete building, or $7 \%$ of the steel building, because of the large amount of sequestered carbon in the wood components of the timber building. The embodied $\mathrm{CO}_{2}$ emissions of the four case study buildings are presented in the table 6.4 below.

\begin{tabular}{|r|r|r|}
\hline Total embodied $\mathrm{CO}_{2}$ emissions & \multicolumn{1}{|c|}{ Alcorn } & $\mathbf{G a B i}$ \\
\hline Concrete building & $1,244.6 \mathrm{t} \mathrm{CO}_{2}$ & $1,451.1 \mathrm{t} \mathrm{CO}_{2}$ \\
\hline Steel building & $1,491.0 \mathrm{t} \mathrm{CO}_{2}$ & $1,674.2 \mathrm{t} \mathrm{CO}_{2}$ \\
\hline Timber building & $244.7 \mathrm{t} \mathrm{CO}_{2}$ & $1,528.1 \mathrm{t} \mathrm{CO}_{2}$ \\
\hline Timber-Plus building & $-445.9 \mathrm{t} \mathrm{CO}_{2}$ & $1,020.6 \mathrm{t} \mathrm{CO}_{2}$ \\
\hline
\end{tabular}

Table 6.4: Case study buildings, total embodied $\mathrm{CO}_{2}$ emissions.

The embodied $\mathrm{CO}_{2}$ emissions from construction of the timber-plus building (-446 $\mathrm{t} \mathrm{CO}_{2}$ ) are negative because the carbon sequestered in the wood components of the timber-plus building greatly exceed all the carbon emitted in the manufacturing of all the other materials in the building.

The difference of embodied $\mathrm{CO}_{2}$ emissions between the four buildings is much less using the $\mathrm{GaBi}$ data because no carbon sequestration is taken into account in that database.

5. What is the influence of construction materials on the relative proportion of embodied energy to total life-cycle energy consumption?

The main influence of construction materials on the relative proportion of embodied energy to total life-cycle energy consumption is represented by the relative proportion of total embodied energy to total life-cycle energy consumption. For the concrete, steel and timber buildings, the total embodied energy is $20 \%$ to $30 \%$ of the total life-cycle energy consumption. For the timber-plus building, the total embodied energy is only $12 \%$ to $15 \%$ of the total life-cycle energy consumption. The actual differences depend on the database used for embodied energy calculations. The embodied energy will become a much larger percentage of the total life-cycle energy consumption if the building is re-designed in the future for much lower operational energy use. The embodied energy (EE) and the total life-cycle energy consumption (Total energy) are compared in table 6.5 below.

\begin{tabular}{|r|c|c|c|c|c|c|c|c|}
\hline & \multicolumn{3}{|l|}{ Concrete } & \multicolumn{2}{c|}{ Steel } & Timber & \multicolumn{2}{c|}{ Timber-Plus } \\
\cline { 2 - 10 } & Alcorn & GaBi & Alcorn & GaBi & Alcorn & GaBi & Alcorn & GaBi \\
\hline EE (GJ) & 19,768 & 15,765 & 29,167 & 20,457 & 19,476 & 15,900 & 11,832 & 8,685 \\
\hline Total energy (GJ) & 83,906 & 79,903 & 94,478 & 85,768 & 86,731 & 83,155 & 77,656 & 74,509 \\
\hline EE (\%) & 24 & 20 & 31 & 24 & 22 & 19 & 15 & 12 \\
\hline
\end{tabular}

Table 6.5: Comparison of embodied energy and life-cycle energy consumption 
6. What is the influence of construction materials on the relative proportion of embodied $\mathrm{CO}_{2}$ emissions $\left(\mathrm{ECO}_{2}\right)$ to total life-cycle $\mathrm{CO}_{2}$ emissions?

The main influence of construction materials on the relative proportion of embodied $\mathrm{CO}_{2}$ emissions to total life-cycle $\mathrm{CO}_{2}$ emissions is represented by the relative proportion of total embodied $\mathrm{CO}_{2}$ emissions to total life-cycle $\mathrm{CO}_{2}$ emissions. Using the Alcorn database, the total embodied $\mathrm{CO}_{2}$ emissions for the concrete and steel buildings are $15 \%$ to $17 \%$ of the total life-cycle $\mathrm{CO}_{2}$ emissions. For the timber building, the total embodied $\mathrm{CO}_{2}$ emissions are only $3 \%$ of the total life-cycle $\mathrm{CO}_{2}$ emissions. This number is very low because the large amount of sequestered carbon in the wood components of the timber building almost balances the carbon emitted from manufacture of other materials. The embodied $\mathrm{CO}_{2}\left(\mathrm{ECO}_{2}\right)$ and the total life-cycle $\mathrm{CO}_{2}$ emissions (Total $\mathrm{CO}_{2}$ ) are compared in table 6.6 below.

\begin{tabular}{|r|c|c|c|c|r|r|r|r|}
\hline & \multicolumn{3}{|l|}{ Concrete } & \multicolumn{2}{l|}{ Steel } & \multicolumn{2}{l|}{ Timber } & \multicolumn{2}{c|}{ Timber-Plus } \\
\cline { 2 - 10 } & Alcorn & GaBi & Alcorn & GaBi & Alcorn & GaBi & Alcorn & GaBi \\
\hline $\mathrm{ECO}_{2}\left(\mathrm{t} \mathrm{CO}_{2}\right)$ & 1,245 & 1,451 & 1,491 & 1,674 & 245 & 1,528 & -446 & 1,021 \\
\hline${\text { Total } \mathrm{CO}_{2}\left(\mathrm{t} \mathrm{CO}_{2}\right)}$ & 8,484 & 8,690 & 8,868 & 9,052 & 7,899 & 9,182 & 6,980 & 8,447 \\
\hline $\mathrm{ECO}_{2}(\%)$ & 15 & 17 & 17 & 18 & 3 & 17 & -6 & 12 \\
\hline
\end{tabular}

Table 6.6: Comparison of embodied $\mathrm{CO}_{2}$ and life-cycle $\mathrm{CO}_{2}$ emissions.

For the timber-plus building, the sequestered $\mathrm{CO}_{2}$ is greater than all the embodied $\mathrm{CO}_{2}$ emissions (as described in the answer to question 4).

\section{How does the choice of finishing materials affect the life-cycle energy use and $\mathrm{CO}_{2}$ emissions?}

We see in section 5.3.1 (Change in building components to reduce the total embodied energy and $\mathrm{CO}_{2}$ emissions) that a big reduction in embodied energy and embodied $\mathrm{CO}_{2}$ emissions can be achieved by maximising the amount of wood and wood products in the building envelope. The largest benefit comes from replacing aluminium with wood, the largest quantities being in the window frames and the sun louvres.

The same type of benefit would occur if a large amount of timber finishing materials was to be used in the concrete and steel buildings. 


\section{How does the use of different sets of embodied energy and embodied $\mathrm{CO}_{2}$ coefficients influence the answers to all previous questions?}

The thesis uses two sets of data, the GaBi and Alcorn database. The GaBi database is theoretically more accurate because it more completely considers the full integrated life cycle production of materials, whereas the Alcorn data is based mostly on energy analysis of single manufacturing plants. However, the GaBi data is based largely on manufacture of European materials and a typical European mix of energy supply, whereas Alcorn uses New Zealand manufacturing and energy data. The biggest differences between the databases relate to sequestered carbon, which is included in the Alcorn database but not in the $\mathrm{GaBi}$ database.

As a consequence of the different approaches taken by Alcorn and $\mathrm{GaBi}$, different results appear for all analyses in this thesis. This can be observed in table 6.5 and 6.6 above, and especially in the table 6.6 comparison of embodied $\mathrm{CO}_{2}$ and life-cycle $\mathrm{CO}_{2}$ emissions. Particularly in the timber and the timber-plus building it is possible to see how the sequestration of $\mathrm{CO}_{2}$ influences the results when Alcorn database is used; for example, using the Alcorn database, the timber-plus building embodied $-446 \mathrm{tCO}_{2}$ while using the $\mathrm{GaBi}$ database the same building embodied $1021 \mathrm{tCO}_{2}$.

\section{Summary and implications of conclusions:}

When looking at life-cycle energy consumption and life-cycle $\mathrm{CO}_{2}$ emissions, building materials can influence both the operating energy consumption and $\mathrm{CO}_{2}$ emissions, and the embodied energy and $\mathrm{CO}_{2}$ emissions of buildings.

From all operating energy end-uses in a low energy office building, the HVAC systems can be reduced to just $25 \%$ of a building's total annual operating energy consumption. The remaining $75 \%$ is consumed by enduses related with the use of the building involving equipment, lifts, lighting, etc.

This thesis concludes that buildings materials have influence mainly in the energy consumed to condition the buildings (HVAC), with the remaining end-uses influenced mainly by the building envelope design and use (activity) of the buildings. The annual 25\% HVAC operating energy consumption of all four case study buildings is equivalent to roughly $19 \%$ of their total 60 year life-cycle energy consumption. By the same token embodied energy represents roughly $23 \%$ of the 60 year life-cycle energy consumption of the four case study buildings.

The former comparison helps us to understand that for low energy office buildings in New Zealand, the influence of reducing embodied energy has an equivalent impact into the life-cycle energy consumption as the influence of materials in the reduction of operating energy consumption. Thus special focus should be given to other broader design considerations to reduce energy consumption, such as lighting (40\% of operating energy consumption).

This research also found that in low energy office buildings, finishing components (not part of a building's primary or secondary structure) can be responsible for a very high proportion of the embodied energy and 


\section{Conclusions}

embodied $\mathrm{CO}_{2}$ emissions. For example, the aluminium sun louvres, although placed to reduce the heat gains inside the offices so as to reduce the use of energy for cooling, actually add large amounts of embodied energy to the buildings. This has the effect of increasing the overall life-cycle energy consumption for the building.

Finally, accounting for the $\mathrm{CO}_{2}$ sequestration of timber (Alcorn) was shown to be highly significant, especially when the case study buildings made extensive use of timber. The most significant benefit came from replacing aluminium with wood, the largest quantities of aluminium being in the window frames and the sun louvres.

Furthermore, technological implications of materials that normally determine material selection were not taken into account in this research. For example the extrusion of aluminium in different shapes allows the production of effective systems used in windows frames and louvres. Future research should be aimed at developing various appropriate 'strategies' for different structural materials. These strategies should be articulated in terms of particular structural advantages against the environmental advantages for the materials concerned. In other words the strategy of steel might be different from the strategy of concrete buildings. Questions about how the structural flexibility of steel helps to achieve sustainable buildings points to one such area for further research.

The following section introduces the most significant areas of further research. 


\subsection{Future research}

- Further research is necessary to compare the concrete, steel, timber and timber-plus buildings individually designed to achieve the best possible energy consumption performance. The study should determine how energy efficient the light weight buildings (steel, timber, and timber-plus) can be compared with an energy efficient design of the concrete building. It would be interesting to evaluate the potential and cost of Phase Change Materials for use in the light weight buildings.

- Further study is required to compare the cost implication of the above exercise, and see the cost evaluation of a highly efficient light weight building against a highly efficient concrete building.

- Another important project is to study the use of waste wood from the timber buildings for biomass energy in lieu of fossil fuel. The waste wood to be considered should include forest harvesting waste, sawmill waste, construction site waste, and demolition waste.

- Other factors not included in this study, which need to be investigated, include the energy and $\mathrm{CO}_{2}$ costs of transportation of building materials, different maintenance and refurbishment schedules, energy required for construction and demolition of buildings.

- It would be very useful to develop a simple energy and carbon calculator to allow building owners or designers to assess the environmental impacts of alternative building systems.

- All of these topics need to be expanded to cover a much larger number of buildings of different types and sizes in different locations. 
Conclusions 


\section{References}

Alcorn, A. (1998). Embodied energy coefficients of building materials. Centre for Building Performance Research, Victoria University of Wellington, New Zealand.

Alcorn, A. (2003). Embodied energy and $\mathrm{CO}_{2}$ coefficients for $\mathrm{NZ}$ building materials. Centre for Building Performance Research, VUW.

Alcorn, A. (2008). Global Sustainability and the New Zealand House. Unpublished PhD thesis. Victoria University of Wellington.

ASHRAE American Society of Heating, R. a. A.-C. E. (2005). 2005 ASHRAE handbook : fundamentals. Atlanta, GA.: ASHRAE.

Aye, L., Bamford, N., Charters, B., \& Robinson, J. (1999). Optimising embodied energy in commercial office development. RICS Foundation, 217-223.

Baird, G., \& Chan, S. A. (1983). Energy costs of houses and light construction buildings and remodelling of existing houses (No. 76). Auckland: New Zealand Energy Research and Development Committee, University of Auckland.

Baird, G., \& Newsam, G. (1986). Estimation of energy consumption in the New Zealand commercial buildings sector. Auckland: New Zealand Energy Research and Development Committee, University of Auckland.

Bellamy, L., \& Mackenzie, D. (2007). Simulation analysis of the energy performance and humidity of solid wood and light timber frame houses. Pine Manufacturers Association Solid Wood Building Initiative.

Bernstein, L., Peter, B., Canziani, O., \& Huq, Z. (2007). IPCC Summary of policymakers. Intergovernamental panel on climate change - fourth assessment report.

Bishop, R. (1992). Energy Use Indices. Wellington.

Borjesson, P., \& Gustavsson , L. (2000). Greenhouse gas balances in building construction: wood versus concrete from life-cycle and forest land-use perspectives. Energy policy, 28, 577-588.

Buchanan, A. (2006). Can timber buildings help reduce global $\mathrm{CO}_{2}$ emissions? Proceedings of the world conference in timber engineering, Portland, USA.

Buchanan, A., Deam, B. L., Fragiacomo, M., Pampanin, S., \& Palermo, A. (2008). Multi-Storey Prestressed Timber Buildings in New Zealand. Structural Engineering International, Journal of the International Association for Bridge and Structural Engineering (IABSE).

Buchanan, A., \& Honey, B. G. (1994). Energy and carbon dioxide implications of building construction. ENERGY AND BUILDINGS, 20(3), 205.

CIBSE, T. C. I. o. B. S. e. L. (2006). Energy efficiency in buildings.

Cole, R. J., \& Kernan, P. C. (1996). Life-cycle energy use in office buildings. Building and Environment, 31(4), 307-317(311). 
CTC Composite technologies corporation. (2008). Thermomass system overview brochure.

DesignBuilder Software. (2008). DesignBuilder user interface for EnergyPlus,. Retrieved from: http://www.designbuilder.co.uk/

Donn, M. (2001). Design comfortable homes. Wellington: Victoria University of Wellington,

Cement and Concrete Association of NZ.

Eaton, K. J., \& Amato, A. (1998). A comparative life cycle assessment of steel and concrete framed office buildings. Journal of constructional steel research, 46(1-3).

Fullbrook, D., \& Jackson, Q. (2005). Value Case for Sustainable Building in New Zealand. Wellington: New Zealand, Ministry of the Environment.

Gustavsson, L., Pingoud, K., \& Sathre, R. (2006). Carbon dioxide balance of wood substitution: comparing concrete- and wood- framed buildings. Mitigation and Adaptation Strategies for Global Change, 11(3), 667-691.

Houghton, J. T., Filho, L. G. M., Callander, B. A., Harris, N., Kattenberg, A., \& Maskell, K. (1998). Climate change 1995 -- The science of climate change. Quarterly journal of the Royal Meteorological Society., 124(549), 1777.

IFIAS. (1974). Energy analysis workshop on methodology and convention, Workshop Report No. 6 Stockholm: International Federation of Institutes for Advanced Study.

Lippke, B., Wilson, J., Perez-Garcia, J., Bowyer, J., \& Meil, J. (2004). CORRIM: Life-Cycle Environmental Performance of Renewable Building Materials. Forest Products Journal, 54(6), 8-19.

Micales, J. A., \& Skog, K. E. (1997). The decomposition of forest products in landfills. International Biodeterioration and Biodegradation, 39(2-3), 145-158.

Mithraratne, N., \& Vale, B. (2004). Life cycle analysis model for New Zealand houses Building and Environment, 39(4), 483-492.

Nebel, B. (2007). Is it valid to use international data in New Zealand LCA studies? Paper presented at the Sustainable building 2007.

Nebel, B., \& Love, S. (2008). Maximising wood plan. Forest research.

New Zealand Business Council for Sustainable Development. (2008). Climate Change: How to Calculate and Report GHG Emissions. Retrieved from: http://www.nzbcsd.org.nz/climatechange/content.asp?id=17

New Zealand Energy Efficiency and Conservation Authority and the Ministry for the Environment. (2006). National Energy Efficiency and Conservation Strategy: Towards a Sustainable Energy Future.

NZ Green Building Council. (2007). Green Star NZ - Office Design v1: Technical Manual.

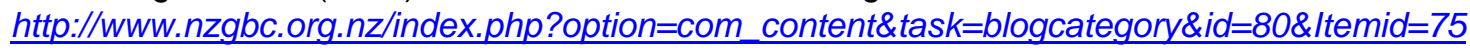

NZ Green Building Council. (2008). Green Star NZ - Office Design v1. http://www.nzgbc.org. $n z / i n d e x . p h p ? o p t i o n=c o m$ content\&task=blogcategory\&id=80\&/temid $=75$ 
NZS. (1996). NZS 4243: 1996 ENERGY EFFICIENCY - LARGE BUILDINGS: Standards New Zealand.

Oppenheim, D., \& Treloar, G. (1995). Embodied energy and office buildings - A case study. Proceedings of the 33rd Australian and New Zealand Solar Energy Society Conference 1, 349 - 354.

Ortiz, O., Castells, F., \& Sonnemann, G. (2007). Sustainability in the construction industry: A review of recent developments based on LCA. Construcccion and building materials.

Page, I. (2006). E408 Timber in Government buildings - cost and evironmental impact analysis (No. QC5018). Porirua: BRANZ Limited.

Paleremo, A., Pampanin, S., Fragiacomo, M., Buchanan, A. H., \& Deam, B. L. (2006). Innovative Seismic Solution for Multi-Storey LVL Timber Buildings. Proceedings, World Conference on Timber Engineering, Portland, USA, August 2006.

Papadopoulos, A. M., \& Giama, E. (2007). Environmental performance evaluation of thermal insulation materials and its impact on the building. Building and environment., 42(5), 2178-2187.

Property Council of New Zealand. (2000). Energy consumption benchmarks : an analysis of the energy expenses incurred by New Zealand CBD office buildings. Auckland, N.Z.: Property Council of New Zealand.

Sartori, I., \& Hestnes, A. G. (2007). Energy use in the life cycle of conventional and low-energy buildings: A review article Energy and buildings, 39, 249-257.

Smith, T., Pampanin, S., Fragiacomo, M., \& Buchanan, A. H. (2008). Design and Construction of Prestressed Timber Buildings for Seismic Areas. Proceedings, World Conference on Timber Engineering, Miyazaki, Japan, June 2008.

Standards Association of New, Z. (1985). Code of practice for interior lighting design. Wellington: The Association.

Standards New Zealand. (1982). Code of practice for energy conservation in non-residential buildings. Wellington: SANZ.

Standards New Zealand. (1997). Energy efficiency : large buildings. Wellington [N.Z.]: Standards New Zealand.

Stein, R. G., Stein, C., Buckley, M., \& Green, M. (1980). Handbook of energy use for building construction (No. DOE/CS/20220-1). Washington, D.C.: Department of energy.

Suzuki, M., \& Oka, T. (1998). Estimation of life cycle energy consumption and CO2 emission of office buildings in Japan. Energy and Buildings 28(1), 33-41.

Szalay, Z., \& Nebel, B. (2006). Analysis of currently available environmental profiles of building products. Reprt TE200. Prepared for BeaconPathway Limited.

Thornton, S., \& New Zealand Ministry for the Environment. (2001). Our clean green image : what's it worth? Wellington, N.Z.: Ministry for the Environment. 


\section{References}

Treloar, G. J., Fay, R., llozor, B., \& Love, P. E. D. (2001). An analysis of the embodied energy of office buildings by height. Facilities, 19(5-6), 204-214(211).

World Green Building Council. (2006). Retrieved from: http://www.worldgbc.org/ 
References 


\section{APPENDIXES:}

\section{A. Background}

\section{A.1 Initial embodied energy and $\mathrm{CO}_{2}$ emissions}

\begin{tabular}{|l|r|r|r|r|r|}
\hline & 3 storeys & \multicolumn{1}{c}{$\mathbf{7}$ storeys } & \multicolumn{1}{c}{15 storeys 42 storeys 52 Storeys } \\
\hline Groos Floor Area (m2) & 6,480 & 27,350 & 47,000 & 99,350 & 129,950 \\
\hline Total embodied energy (Gj) & 69,622 & 326,766 & 754,537 & $1,787,073$ & $2,388,535$ \\
\hline EE (GJ/m2) & 10.7 & 11.9 & 16.1 & 18.0 & 18.4 \\
\hline
\end{tabular}

Table A.1: Case study final embodied energy by square meter (Treloar, Fay, llozor, \& Love, 2001).

Analysed office buildings

\begin{tabular}{|c|c|c|c|c|c|c|c|c|c|c|}
\hline & A & B & C & D & E & $\mathbf{F}$ & G & $\mathbf{H}$ & I & $\mathbf{J}$ \\
\hline Completion & 1976 & 1979 & 1986 & 1987 & 1987 & 1988 & 1989 & 1989 & 1989 & 1987 \\
\hline Floor area $\left(\mathrm{m}^{2}\right)$ & 1879 & 1404 & 1857 & 1340 & 1328 & 1253 & 1358 & 1358 & 8458 & 22982 \\
\hline Stories & F7-B1 & F7 & F7-B1 & F7 & F7 & F7-B1 & F7 & F7 & F9-B1 & F8-B2 \\
\hline Structure & $\mathrm{RC}$ & $\mathrm{RC}$ & $\mathrm{RC}$ & $\mathrm{RC}$ & $\mathrm{RC}$ & $\mathrm{RC}$ & $\mathrm{RC} / \mathrm{S}$ & $\mathrm{RC} / \mathrm{S}$ & SRC & S \\
\hline
\end{tabular}

Table A.2: Case study for quantities analysis (Suzuki \& Oka, 1998).

Energy intensity of construction (MJ / 1000 yen)

Temporoary works
Structure
Finishing
Equipment
General expenditure
Average

\begin{tabular}{l} 
A \\
\hline B
\end{tabular}

$\mathrm{CO}_{2}$ intensity of construction ( $\mathrm{kg} / 1000$ yen )

\begin{tabular}{|c|c|c|c|c|c|c|c|c|c|c|c|}
\hline \multirow{6}{*}{$\begin{array}{l}\text { Temporoary works } \\
\text { Structure } \\
\text { Finishing } \\
\text { Equipment } \\
\text { General expenditure } \\
\text { Average }\end{array}$} & 1.8 & 2.1 & 2.1 & 2.3 & 2.2 & 2.1 & 2.4 & 2.4 & 7.0 & 2.2 & 2.7 \\
\hline & 7.5 & 6.2 & 5.5 & 4.9 & 5.2 & 4.7 & 5.1 & 5.1 & 7.1 & 9.3 & 6.1 \\
\hline & 2.1 & 3.0 & 2.8 & 3.3 & 3.2 & 3.0 & 3.2 & 7.5 & 5.7 & 4.7 & 3.8 \\
\hline & 2.6 & 2.6 & 2.2 & 2.5 & 2.5 & 2.4 & 2.5 & 2.5 & 2.3 & 2.5 & 2.5 \\
\hline & 0.4 & 0.4 & 0.5 & 0.4 & 0.5 & 0.4 & 0.4 & 0.4 & 1.0 & 1.1 & 0.6 \\
\hline & 3.2 & 3.2 & 3.0 & 3.3 & 3.1 & 3.0 & 3.2 & 3.9 & 4.3 & 4.4 & 3.6 \\
\hline
\end{tabular}

Table A.3: Energy intensity of construction (MJ / 1000 yen) and $\mathrm{CO}_{2}$ intensity of construction (kg I 1000 yen) (Suzuki \& Oka, 1998). 


\section{A.2 Total initial embodied energy subdivided by components:}

\begin{tabular}{l} 
Component \\
\hline With underground parking \\
Site work \\
Structure \\
Envelope \\
Finishes \\
Services \\
Construction \\
Total \\
$\mathbf{G J} / \mathbf{m}^{2}$
\end{tabular}

\begin{tabular}{cccccc}
\hline Wood & \multicolumn{2}{c}{ Steel } & \multicolumn{3}{c}{ Concrete } \\
\hline GJ & $\%$ & GJ & $\%$ & GJ & $\%$ \\
\hline
\end{tabular}

No underground parking

Site work

Structure

Envelope

Finishes

Services

Construction

Total

\begin{tabular}{|r|r|r|r|r|r|}
\hline $1,246.00$ & 5.9 & $1,246.00$ & 5.3 & $1,246.00$ & 5.6 \\
\hline $4,268.00$ & 20.3 & $6,836.00$ & 28.9 & $5,398.00$ & 24.4 \\
\hline $5,935.00$ & 28.3 & $5,964.00$ & 25.2 & $5,822.00$ & 26.3 \\
\hline $2,900.00$ & 13.8 & $2,825.00$ & 11.9 & $2,945.00$ & 13.3 \\
\hline $5,263.00$ & 25.1 & $5,263.00$ & 22.2 & $5,263.00$ & 23.8 \\
\hline $1,373.00$ & 6.5 & $1,549.00$ & 6.5 & $1,447.00$ & 6.5 \\
\hline $\mathbf{2 0 , 9 8 5 . 0 0}$ & $\mathbf{1 0 0}$ & $\mathbf{2 3 , 6 8 3 . 0 0}$ & $\mathbf{1 0 0}$ & $\mathbf{2 2 , 1 2 1 . 0 0}$ & $\mathbf{1 0 0}$ \\
$\mathbf{4 . 5 4}$ & & $\mathbf{5 . 1 3}$ & & $\mathbf{4 . 7 9}$ & \\
& & & & & \\
\end{tabular}

$\mathrm{GJ} / \mathrm{m}^{2}$

\begin{tabular}{|r|r|r|r|r|r|}
\hline $1,344.00$ & 6.8 & $1,344.00$ & 6 & $1,344.00$ & 6.4 \\
\hline $3,088.00$ & 15.7 & $5,650.00$ & 25.2 & $4,303.00$ & 20.6 \\
\hline $5,935.00$ & 30.1 & $6,062.00$ & 27 & $5,822.00$ & 27.9 \\
\hline $2,935.00$ & 14.9 & $2,799.00$ & 12.5 & $2,920.00$ & 14 \\
\hline $5,110.00$ & 25.9 & $5,110.00$ & 22.8 & $5,110.00$ & 24.5 \\
\hline $1,289.00$ & 6.5 & $1,468.00$ & 6.5 & $1,365.00$ & 6.5 \\
\hline $\mathbf{1 9 , 7 0 1 . 0 0}$ & $\mathbf{1 0 0}$ & $\mathbf{2 2 , 4 3 3 . 0 0}$ & $\mathbf{1 0 0}$ & $\mathbf{2 0 , 8 6 4 . 0 0}$ & $\mathbf{1 0 0}$ \\
\hline
\end{tabular}

Difference of u/g parking (\%)

$\begin{array}{lll}4.26 & 4.86 & 4.52\end{array}$

6.50

5.6

6

Table A.4: Summary of total initial embodied energy (Cole \& Kernana, 1996).

\begin{tabular}{|c|c|c|c|}
\hline With underground parking & Timber & Steel & Concrete \\
\hline \multirow{2}{*}{$\begin{array}{l}\text { Total GJ } \\
\mathrm{GJ} / \mathrm{m}^{2}\end{array}$} & 4,268 & 6,836 & 5,398 \\
\hline & 0.92 & 1.48 & 1.17 \\
\hline No underground parking & Timber & Steel & Concrete \\
\hline Total GJ & 3,088 & 5,650 & 4,303 \\
\hline $\mathrm{GJ} / \mathrm{m}^{2}$ & 0.67 & 1.22 & 0.93 \\
\hline Difference of u/g parking (\%) & 38.2 & 21 & 25.4 \\
\hline
\end{tabular}

Table A. A.1: Initial embodied energy of structural system (Cole \& Kernana, 1996).

\begin{tabular}{|l|r|r|r|r|r|}
\multicolumn{1}{c}{ 日EM } & B storeys & \multicolumn{1}{c}{$\mathbf{7}$ storeys } & \multicolumn{1}{c}{ 15 storeys } & 42 storeys & 52 Storeys \\
\hline Substructure & $6,006.0$ & $10,398.0$ & $54,812.0$ & $52,463.0$ & $90,183.0$ \\
\hline Columns & $3,981.0$ & $13,241.0$ & $51,669.0$ & $318,475.0$ & $179,145.0$ \\
\hline Upper floors & $20,133.0$ & $146,444.0$ & $213,099.0$ & $649,146.0$ & $942,500.0$ \\
\hline Staircases & 716.0 & $1,261.0$ & $6,236.0$ & $9,947.0$ & $5,226.0$ \\
\hline Roof & $6,241.0$ & $21,929.0$ & $4,604.0$ & $22,344.0$ & $48,397.0$ \\
\hline External ealls & $5,085.0$ & $17,988.0$ & $138,421.0$ & $79,698.0$ & $167,373.0$ \\
\hline Window s & $2,189.0$ & $5,354.0$ & 0.0 & $23,638.0$ & $11,637.0$ \\
\hline Internall w alls & $2,799.0$ & $11,834.0$ & $55,335.0$ & $102,298.0$ & $210,428.0$ \\
\hline Wall finishes & 270.0 & $4,445.0$ & $5,866.0$ & $5,446.0$ & $9,452.0$ \\
\hline Floor finishes & $2,726.0$ & $2,701.0$ & $12,739.0$ & $32,820.0$ & $40,228.0$ \\
\hline Ceiling finishes & 570.0 & $2,438.0$ & $6,856.0$ & $5,511.0$ & $35,347.0$ \\
\hline Direct energy & $5,678.0$ & $6,313.0$ & $8,482.0$ & $9,504.0$ & $9,712.0$ \\
\hline Other items & $13,229.0$ & $14,709.0$ & $19,763.0$ & $22,144.0$ & $22,629.0$ \\
\hline Total & $\mathbf{6 9 , 6 2 2}$ & $\mathbf{3 2 6 , 7 6 6}$ & $\mathbf{7 5 4 , 5 3 7}$ & $\mathbf{1 , 7 8 7 , 0 7 3}$ & $\mathbf{2 , 3 8 8 , 5 3 5}$ \\
\hline GJ/m 2 & $\mathbf{1 0 . 7}$ & $\mathbf{1 2 . 0}$ & $\mathbf{1 6 . 1}$ & $\mathbf{1 8 . 0}$ & $\mathbf{1 8 . 4}$ \\
\hline
\end{tabular}

Table A.5: Case study building embodied energy results (GJ), by elements (Treloar, Fay, llozor, \& Love, 2001). 


\section{A.3 Recurring embodied energy and $\mathrm{CO}_{2}$}

Buildings life

\begin{tabular}{|c|c|c|c|c|c|c|}
\hline & \multicolumn{2}{|l|}{25 years } & \multicolumn{2}{|l|}{50 years } & \multicolumn{2}{|l|}{100 years } \\
\hline & Energy (GJ) & Increase (\%) & Energy (GJ) & Increase (\%) & Energy (GJ) & Increase (\%) \\
\hline \multicolumn{7}{|c|}{ With underground parking } \\
\hline Site work & $\begin{array}{r}65.0 \\
\end{array}$ & 5.2 & 357.0 & 28.6 & 0.0 & 0 \\
\hline Structure & 0.0 & 0 & 0.0 & 0 & 0.0 & 0 \\
\hline Envelope & 3873.0 & 65.3 & 150.7 & 150.7 & 20060.0 & 338 \\
\hline Finishes & 3869.0 & 133.4 & 322.0 & 322 & 21046.0 & 725.7 \\
\hline Services & 3369.0 & 64 & 188.5 & 188.5 & 23093.0 & 438.8 \\
\hline Construction & 671.0 & 48.9 & 124.8 & 124.8 & 3911.0 & 284.9 \\
\hline Total & 11847.0 & 56.5 & 1143.0 & 144.3 & 68110.0 & 324.6 \\
\hline GJ/m2 & 2.56 & & 5.13 & & 14.74 & \\
\hline
\end{tabular}

No underground parking

Site work

Structure

Envelope

Finishes

Services

Construction

Total

\begin{tabular}{|r|r|}
\hline 65.0 & 4.9 \\
\hline 0.0 & 0 \\
\hline 3873.0 & 65.3 \\
\hline 3696.0 & 125.9 \\
\hline 3338.0 & 65.3 \\
\hline 658.0 & 51.1 \\
\hline $\mathbf{1 1 6 3 0 . 0}$ & $\mathbf{5 9}$ \\
\hline
\end{tabular}

\begin{tabular}{|r|r|}
\hline 358.0 & 26.7 \\
\hline 0.0 & 0 \\
\hline 8943.0 & 150 \\
\hline 8397.0 & 286.2 \\
\hline 9859.0 & 192.9 \\
\hline 1653.0 & 128.3 \\
\hline $\mathbf{2 9 2 1 0 . 0}$ & 148.3 \\
\hline
\end{tabular}

\begin{tabular}{|r|r|}
\hline 1001.0 & 74.5 \\
\hline 0.0 & 0 \\
\hline 20060.0 & 338 \\
\hline 18936.0 & 645.3 \\
\hline 22955.0 & 449.2 \\
\hline 3777.0 & 293.1 \\
\hline 66729.0 & 338.7 \\
\hline
\end{tabular}

GJ/m2

2.52

6.32

14.44

Table A.6: Summary of recurring embodied energy (wood structure) (Cole \& Kernana, 1996). 


\section{B. Methodology}

\section{B.1 Operating energy}

Wall construction

1 Concrete building

East and West facades: Concrete / Thermomass

South facades: Concrete / Thermomass

Light weight envelope wall / cavity

Light weight envelope wall / structure

North Façade: Glassing Courtain wall

Roof: Concrete / roof Floor (ceiling incl)

Internal floor: Concrete / Internal Floor (ceiling incl)

Ground floor: Concrete / Ground Floor

2 Steel Building

East and West facades: Light weight envelope wall / cavity

Light weight envelope wall / structure

South facades: Light weight, south wall / cavity

Light weight, south wall / structure

North Façade: Glassing Courtain wall

Roof: Steel / Roof slab (ceiling incl)

Internal floor: Steel / Internal floor (ceiling incl)

Ground floor: Concrete / Ground Floor

\section{Timber Building}

East / West / south facades: LVL Shear Wall

Light weight envelope wall / cavity

Light weight envelope wall / structure

South facades: Light weight envelope wall / cavity

Light weight envelope wall / structure

North Façade: Glassing Courtain wall

Roof: Timber / Roof slab (ceiling incl)

Internal floor: Timber / Internal Floor (ceiling incl)

Ground floor: Concrete / Ground Floor

4 Timber Plus Building

East and West facades: LVL Shear Wall

Light weight envelope wall / cavity

Light weight envelope wall / structure

South facades: Chimney, south wall / cavity

Chimney, south wall / structure

North Façade: Light weight envelope wall

Glassing Courtain wall

Roof: Timber / Roof slab

Internal floor: Timber / Internal Floor

Ground floor: Concrete / Ground Floor
Thicknees

R/Value \% in wall

\begin{tabular}{|c|c|c|}
\hline $310 \mathrm{~mm}$ & 2.02 & $100 \%$ \\
\hline $310 \mathrm{~mm}$ & 2.02 & $22 \%$ \\
\hline $137 \mathrm{~mm}$ & 2.68 & $73 \%$ \\
\hline $137 \mathrm{~mm}$ & 1.50 & $6 \%$ \\
\hline $50 \mathrm{~mm}$ & 0.56 & $100 \%$ \\
\hline $814.5 \mathrm{~mm}$ & 2.59 & $100 \%$ \\
\hline $814.5 \mathrm{~mm}$ & 0.79 & $100 \%$ \\
\hline $1327 \mathrm{~mm}$ & 2.80 & $100 \%$ \\
\hline
\end{tabular}

\begin{tabular}{|r|}
\hline $138.5 \mathrm{~mm}$ \\
\hline $138.5 \mathrm{~mm}$ \\
\hline $147 \mathrm{~mm}$ \\
\hline $147 \mathrm{~mm}$ \\
\hline $25 \mathrm{~mm}$ \\
\hline $814.5 \mathrm{~mm}$ \\
\hline $814.5 \mathrm{~mm}$ \\
\hline $1327 \mathrm{~mm}$ \\
\hline
\end{tabular}

\begin{tabular}{|l|}
\hline 2.65 \\
\hline 0.23 \\
\hline 2.68 \\
\hline 0.25 \\
\hline 0.56 \\
\hline 2.47 \\
\hline 0.67 \\
\hline 2.80 \\
\hline
\end{tabular}

\begin{tabular}{|r|}
\hline $97 \%$ \\
\hline $3 \%$ \\
\hline $97 \%$ \\
\hline $3 \%$ \\
\hline $100 \%$ \\
\hline $100 \%$ \\
\hline $100 \%$ \\
\hline $100 \%$ \\
\hline
\end{tabular}

\begin{tabular}{|r|}
\hline $286 \mathrm{~mm}$ \\
\hline $137 \mathrm{~mm}$ \\
\hline $135 \mathrm{~mm}$ \\
\hline $137 \mathrm{~mm}$ \\
\hline $135 \mathrm{~mm}$ \\
\hline $25 \mathrm{~mm}$ \\
\hline $864.5 \mathrm{~mm}$ \\
\hline $814.5 \mathrm{~mm}$ \\
\hline $1327 \mathrm{~mm}$ \\
\hline
\end{tabular}

\begin{tabular}{|l|}
\hline 2.06 \\
\hline 2.68 \\
\hline 1.50 \\
\hline 2.68 \\
\hline 1.50 \\
\hline 0.56 \\
\hline 2.58 \\
\hline 0.78 \\
\hline 2.80 \\
\hline
\end{tabular}

\begin{tabular}{|r|}
\hline $72 \%$ \\
\hline $27 \%$ \\
\hline $1 \%$ \\
\hline $90 \%$ \\
\hline $10 \%$ \\
\hline $100 \%$ \\
\hline $100 \%$ \\
\hline $100 \%$ \\
\hline $100 \%$ \\
\hline
\end{tabular}

\begin{tabular}{|r|}
\hline $331 \mathrm{~mm}$ \\
\hline $144 \mathrm{~mm}$ \\
\hline $144 \mathrm{~mm}$ \\
\hline $149 \mathrm{~mm}$ \\
\hline $149 \mathrm{~mm}$ \\
\hline $144 \mathrm{~mm}$ \\
\hline $25 \mathrm{~mm}$ \\
\hline $864 \mathrm{~mm}$ \\
\hline $814.5 \mathrm{~mm}$ \\
\hline $1327 \mathrm{~mm}$ \\
\hline
\end{tabular}

\begin{tabular}{|l|}
\hline 2.42 \\
\hline 2.81 \\
\hline 1.23 \\
\hline 2.84 \\
\hline 1.23 \\
\hline 2.84 \\
\hline 0.56 \\
\hline 2.58 \\
\hline 0.78 \\
\hline 2.80 \\
\hline
\end{tabular}

\begin{tabular}{|r|}
\hline $72 \%$ \\
\hline $27 \%$ \\
\hline $1 \%$ \\
\hline $90 \%$ \\
\hline $10 \%$ \\
\hline $30 \%$ \\
\hline $70 \%$ \\
\hline $100 \%$ \\
\hline $100 \%$ \\
\hline $100 \%$ \\
\hline
\end{tabular}


Table B.1: Shows the office areas envelope walls configuration including thickness and R/values of the concrete, steel, timber and timber-plus buildings.

\section{B.2 Recurrent energy}

From: Life Cycle Costing for Design Professionals

Material

Useful Life

\begin{tabular}{|l|r|}
\hline Balustrading (glass) ("Balcony Walls and Handrails - Glass Panels") & 40 \\
\hline Precast Concrete Stairs & 50 \\
\hline Steel stairs & 40 \\
\hline Cedar/Redwood siding (cladding) & 40 \\
\hline Plywood Siding & 30 \\
\hline Corrugated Metal Deck (comflor) & 30 \\
\hline Metal soffits & 40 \\
\hline Cast iron roof drains & 40 \\
\hline Exterior metal panels & $30+$ \\
\hline Acoustic Ceiling Tile, Fibre Cement & 20 \\
\hline
\end{tabular}

From: Princeton University Design Standards Manual

Material

Useful life

\begin{tabular}{|l|r|}
\hline Aluminium Louves & 60 \\
\hline Wood Handrails (used for balustrading) & 10 \\
\hline Plywood Panelling (plywood roofs/floors) & 40 \\
\hline Plywood siding (ext walls) & 30 \\
\hline "Acoustic tile" (Plasterboard) & 20 \\
\hline Stairs - pressure treated lumber & 15 \\
\hline Wood finish carpentry/millwork (interior wood cladding) & $60-80$ \\
\hline
\end{tabular}

From: Life Cycle Assessment of a New Zealand house All foundations/floor framing/wall framing/piles

Building Life

\begin{tabular}{|l|r|}
\hline Fibre Cement Walls & 50 \\
\hline Weatherboard/wooden panelling & 40 \\
\hline Plasterboard lining & 40 \\
\hline Plasterboard ceiling lining and battens & 40 \\
\hline Steel roofing, battens, insulation & 40 \\
\hline Interior paint & 8 \\
\hline Exterior paint & 8 \\
\hline Window frames and glazing & 40 \\
\hline External doors, frames & 40 \\
\hline Internal doors & 40 \\
\hline
\end{tabular}

Table B.2: Shows the schedule of buildings materials life spans organized by three sources. 


\section{B.3 Embodied energy}

\begin{tabular}{|rl|}
\hline Material in QS schedule & \multicolumn{1}{c|}{ Alternatives in Alcorn 2003 report } \\
\hline Concrete: & - Concrete: $17.5 \mathrm{MPa}$ \\
& - Concrete: $30 \mathrm{MPa}$ \\
\hline Reinforcing Steel: & - Recycled, reinf, sections \\
\hline Structural Steel: & - Steel, virgin, structural \\
\hline Other Steel: & - Zincalume, 0.55mm steel \\
& - Galvanised, $0.55 \mathrm{~mm}$ steel \\
\hline Glass: & - Glass: toughened \\
& - Glass, float/tint \\
\hline Timber: & - Timber, pine, kiln dried, dressed, treated \\
& - Plywood \\
\hline Aluminium: & - Aluminium extruded, anodized \\
\hline Plasterboard: & - plaster board \\
\hline Paint: & - Paint, outside on Fibre cement \\
& - Paint, inside \\
\hline Particleboard/fibreboard: & - Cement fibre board \\
\hline Insulation: & - Insulation, fibreglass \\
& - Polystyrene, extruded \\
\hline
\end{tabular}

Table B.3: Concrete building schedule of building materials suggested by the Quantitative Surveyor and then the specific alternative assigned from Alcorn (2003). 


\begin{tabular}{|c|c|c|c|c|c|c|c|c|c|}
\hline \multirow[t]{2}{*}{ Database } & \multicolumn{2}{|c|}{ Alcorn } & \multicolumn{5}{|c|}{ GaBi } & \multicolumn{2}{|c|}{$\begin{array}{c}\text { Alcorn as a } \\
\text { percentage of } \mathrm{GaBi}\end{array}$} \\
\hline & $\begin{array}{l}\text { Embodied } \\
\text { energy } \\
(\mathrm{MJ} / \mathrm{kg})\end{array}$ & $\begin{array}{l}\mathrm{CO}_{2} \\
\text { emissions } \\
(\mathrm{kg} / \mathrm{kg})\end{array}$ & $\begin{array}{l}\text { Energy non- } \\
\text { renewable } \\
(\mathrm{MJ} / \mathrm{kg})\end{array}$ & $\begin{array}{l}\text { Energy } \\
\text { renewable } \\
(\mathrm{MJ} / \mathrm{kg})\end{array}$ & $\begin{array}{l}\text { Total } \\
\text { energy } \\
(\mathrm{MJ} / \mathrm{kg})\end{array}$ & $\begin{array}{l}\text { GWP } \\
\left(\mathrm{CO}_{2} \mathrm{eq}\right)\end{array}$ & $\begin{array}{l}\mathrm{CO}_{2} \\
\text { emissions } \\
(\mathrm{kg} / \mathrm{kg})\end{array}$ & $\begin{array}{c}\text { Embodied } \\
\text { energy } \\
(\%)\end{array}$ & $\begin{array}{c}\mathrm{CO}_{2} \\
\text { emissions } \\
\quad(\%)\end{array}$ \\
\hline Agregate, general & 0.04 & 0.002 & 0.30 & 0.00 & 0.03 & 0.002 & 0.002 & 127 & 114 \\
\hline Aluminium, virgin & 191.55 & 8.000 & 199.31 & 28.50 & 227.81 & 16.821 & 12.741 & 84 & 63 \\
\hline Alu, virgin, extrude & 201.74 & 8.354 & 206.72 & 33.06 & 239.78 & 17.389 & 13.182 & 84 & 63 \\
\hline Alu, virgin, extrude, anodised & 226.38 & 9.359 & 333.89 & 40.75 & 374.64 & 25.542 & 20.546 & 60 & 46 \\
\hline Alu, recicled, extrude, anodised & 23.83 & 0.886 & 146.04 & 10.79 & 156.83 & 9.361 & 8.386 & 15 & 11 \\
\hline Alu, recicled, extrude & 14.56 & 0.721 & 20.16 & 3.41 & 23.57 & 1.554 & 1.021 & 62 & 71 \\
\hline Bitumen, feedstock & 2.40 & 0.171 & 45.63 & 0.01 & 45.64 & 0.373 & 0.305 & 5 & 56 \\
\hline Brick & 2.70 & 0.138 & 2.99 & 0.02 & 3.01 & 0.189 & 0.178 & 90 & 77 \\
\hline Cement, average & 6.16 & 0.994 & 4.32 & 0.12 & 4.43 & 0.722 & 0.710 & 139 & 140 \\
\hline Concrete ready mix, $17.5 \mathrm{MPa}$ & 0.86 & 0.114 & 0.73 & 0.01 & 0.74 & 0.107 & 0.106 & 115 & 108 \\
\hline Concrete ready mix, 30MPa & 1.17 & 0.159 & 0.84 & 0.02 & 0.86 & 0.136 & 0.133 & 136 & 119 \\
\hline Concrete roofing tile & 0.81 & & 1.28 & 0.03 & 1.31 & 0.186 & 0.179 & 62 & \\
\hline Copper, virgin, sheet & 97.64 & 7.738 & 45.23 & 4.90 & 50.13 & 3.211 & 3.019 & 195 & 256 \\
\hline Fibre cement board & 9.36 & 0.629 & 15.77 & 0.12 & 15.88 & 1.258 & 1.207 & 59 & 52 \\
\hline Glass, float, tint & 15.89 & 1.735 & 13.35 & 0.05 & 13.40 & 1.355 & 1.286 & 119 & 135 \\
\hline Gypsum plasterboard & 7.37 & 0.421 & 3.89 & 0.29 & 4.18 & 0.176 & 0.167 & 176 & 252 \\
\hline Insulation, polystyrene & 58.36 & 2.495 & 92.51 & 0.17 & 92.68 & 2.863 & 2.668 & 63 & 94 \\
\hline Insulation, fiberglass & 32.07 & 0.770 & 39.32 & 2.22 & 41.55 & 2.396 & 2.255 & 77 & 34 \\
\hline Plastic, HDPE & 50.97 & 3.447 & 73.97 & 0.39 & 74.36 & 1.278 & 0.940 & 69 & 267 \\
\hline Plastic, LDPE & 50.97 & 3.539 & 80.80 & 0.54 & 81.34 & 1.588 & 1.250 & 63 & 283 \\
\hline Plastic, PVC, extruded & 60.86 & 4.349 & 58.90 & 0.35 & 59.25 & 2.332 & 2.177 & 103 & 200 \\
\hline Sand & 0.10 & 0.007 & 0.03 & 0.00 & 0.03 & 0.002 & 0.002 & 293 & 334 \\
\hline Steel, virgin, general & 31.31 & 1.242 & 22.52 & 0.39 & 22.91 & 1.457 & 1.312 & 137 & 95 \\
\hline Steel, stainless, average & 74.82 & 5.457 & 53.79 & 6.29 & 60.08 & 4.838 & 4.624 & 125 & 118 \\
\hline Timber, air dried, roughsawn, untreated & 2.81 & -1.665 & 0.53 & 17.22 & 17.75 & 0.034 & -1.802 & 16 & 92 \\
\hline Timber, Kiln dried, gas fired, dressed & 9.52 & -1.349 & 1.35 & 21.14 & 22.49 & 0.509 & -1.329 & 42 & 102 \\
\hline Timber glulam & 13.64 & -1.141 & 7.85 & 30.42 & 38.27 & 1.802 & -0.053 & 36 & 2,160 \\
\hline
\end{tabular}

Table B.4: Comparison of the Alcorn and the GaBi data on embodied energy and embodied $\mathrm{CO}_{2}$ emissions of 27 buildings materials. 


\section{Results}

\section{C.1 Operating energy consumption}

Energy consumption in Operation

End-uses kWh.yr

$\mathrm{kWh} / \mathrm{m}^{2} \cdot \mathrm{yr}$

GJ

1 Concrete building

\begin{tabular}{|l|r|}
\hline Cooling & $31,831 \mathrm{kWh}$ \\
\hline Heating & $42,437 \mathrm{kWh}$ \\
\hline DHW & $14,146 \mathrm{kWh}$ \\
\hline System Misc (lift) & $12,509 \mathrm{kWh}$ \\
\hline Lighting & $120,403 \mathrm{kWh}$ \\
\hline Room Electricity & $\mathbf{7 5 , 6 1 0 \mathrm { kWh }}$ \\
\hline Total: & $\mathbf{2 9 6 , 9 3 5} \mathbf{~ k W h}$ \\
\hline
\end{tabular}

\begin{tabular}{|r|}
\hline $9 \mathrm{kWh} / \mathrm{m}^{2}$ \\
\hline $12 \mathrm{kWh} / \mathrm{m}^{2}$ \\
\hline $4 \mathrm{kWh} / \mathrm{m}^{2}$ \\
\hline $4 \mathrm{kWh} / \mathrm{m}^{2}$ \\
\hline $34 \mathrm{kWh} / \mathrm{m}^{2}$ \\
\hline $21 \mathrm{kWh} / \mathrm{m}^{2}$ \\
\hline $\mathbf{8 4} \mathrm{kWh} / \mathrm{m}^{2}$ \\
\hline
\end{tabular}

\begin{tabular}{|r|}
\hline $115 \mathrm{GJ}$ \\
\hline $153 \mathrm{GJ}$ \\
\hline $51 \mathrm{GJ}$ \\
\hline $45 \mathrm{GJ}$ \\
\hline $433 \mathrm{GJ}$ \\
\hline $272 \mathrm{GJ}$ \\
\hline $\mathbf{1 , 0 6 9} \mathbf{~ G J}$ \\
\hline
\end{tabular}

2 Steel building

\begin{tabular}{|c|c|}
\hline Cooling & $39,176 \mathrm{kWh}$ \\
\hline Heating & $43,037 \mathrm{kWh}$ \\
\hline DHW & $14,146 \mathrm{kWh}$ \\
\hline System Misc (lift) & $12,509 \mathrm{kWh}$ \\
\hline Lighting & $120,403 \mathrm{kWh}$ \\
\hline Room electricity & $73,092 \mathrm{kWh}$ \\
\hline
\end{tabular}

\begin{tabular}{|c|}
\hline $11 \mathrm{kWh} / \mathrm{m}^{2}$ \\
\hline $12 \mathrm{kWh} / \mathrm{m}^{2}$ \\
\hline $4 \mathrm{kWh} / \mathrm{m}^{2}$ \\
\hline $4 \mathrm{kWh} / \mathrm{m}^{2}$ \\
\hline $34 \mathrm{kWh} / \mathrm{m}^{2}$ \\
\hline $21 \mathrm{kWh} / \mathrm{m}^{2}$ \\
\hline $\mathbf{8 6} \mathrm{kWh} / \mathrm{m}^{2}$ \\
\hline
\end{tabular}

\begin{tabular}{|r|}
\hline $141 \mathrm{GJ}$ \\
\hline $155 \mathrm{GJ}$ \\
\hline $51 \mathrm{GJ}$ \\
\hline $45 \mathrm{GJ}$ \\
\hline $433 \mathrm{GJ}$ \\
\hline $263 \mathrm{GJ}$ \\
\hline $\mathbf{1 , 0 8 9} \mathbf{~ G J}$ \\
\hline
\end{tabular}

3

\begin{tabular}{|l|r|}
\hline Cooling & $47,304 \mathrm{kWh}$ \\
\hline Heating & $40,607 \mathrm{kWh}$ \\
\hline DHW & $14,146 \mathrm{kWh}$ \\
\hline System Misc (lift) & $12,509 \mathrm{kWh}$ \\
\hline Lighting & $120,403 \mathrm{kWh}$ \\
\hline Room electricity & $76,399 \mathrm{kWh}$ \\
\hline Total: & $\mathbf{3 1 1 , 3 6 7} \mathbf{~ k W h}$ \\
\hline
\end{tabular}

\begin{tabular}{|c|}
\hline $13 \mathrm{kWh} / \mathrm{m}^{2}$ \\
\hline $11 \mathrm{kWh} / \mathrm{m}^{2}$ \\
\hline $4 \mathrm{kWh} / \mathrm{m}^{2}$ \\
\hline $4 \mathrm{kWh} / \mathrm{m}^{2}$ \\
\hline $34 \mathrm{kWh} / \mathrm{m}^{2}$ \\
\hline $22 \mathrm{kWh} / \mathrm{m}^{2}$ \\
\hline $\mathbf{8 8} \mathrm{kWh} / \mathrm{m}^{2}$ \\
\hline
\end{tabular}

\begin{tabular}{|c|}
\hline $170 \mathrm{GJ}$ \\
\hline $146 \mathrm{GJ}$ \\
\hline $51 \mathrm{GJ}$ \\
\hline $45 \mathrm{GJ}$ \\
\hline $433 \mathrm{GJ}$ \\
\hline $275 \mathrm{GJ}$ \\
\hline $\mathbf{1 , 1 2 1} \mathbf{~ G J}$ \\
\hline
\end{tabular}

4 Timber-Plus building

\begin{tabular}{|l|r|}
\hline Cooling & $37,141 \mathrm{kWh}$ \\
\hline Heating & $44,142 \mathrm{kWh}$ \\
\hline DHW & $14,146 \mathrm{kWh}$ \\
\hline System Misc (lift) & $12,509 \mathrm{kWh}$ \\
\hline Lighting & $120,403 \mathrm{kWh}$ \\
\hline Room electricity & $76,399 \mathrm{kWh}$ \\
\hline Total: & $\mathbf{3 0 4 , 7 4 0} \mathbf{~ k W h}$ \\
\hline
\end{tabular}

\begin{tabular}{|c|}
\hline $11 \mathrm{kWh} / \mathrm{m}^{2}$ \\
\hline $12 \mathrm{kWh} / \mathrm{m}^{2}$ \\
\hline $4 \mathrm{kWh} / \mathrm{m}^{2}$ \\
\hline $4 \mathrm{kWh} / \mathrm{m}^{2}$ \\
\hline $34 \mathrm{kWh} / \mathrm{m}^{2}$ \\
\hline $22 \mathrm{kWh} / \mathrm{m}^{2}$ \\
\hline $\mathbf{8 6} \mathrm{kWh} / \mathrm{m}^{2}$ \\
\hline
\end{tabular}

\begin{tabular}{|c|}
\hline $134 \mathrm{GJ}$ \\
\hline $159 \mathrm{GJ}$ \\
\hline $51 \mathrm{GJ}$ \\
\hline $45 \mathrm{GJ}$ \\
\hline $433 \mathrm{GJ}$ \\
\hline $275 \mathrm{GJ}$ \\
\hline $\mathbf{1 , 0 9 7} \mathbf{G J}$ \\
\hline
\end{tabular}

Net Usable Area:

$3,536 \mathrm{~m}^{2}$

Table C.1: Operational energy segregated in consumption components. 


\section{C.2 Comparison between the concrete and timber buildings as examples of a high and low thermal mass buildings respectively}

Graphs compare the internal operative temperature of the concrete building and the outside Dry-Bulb temperature in Figure C.1 and C.3. The concrete building is then compared with the timber building in figure C.2 and C.4. Inside operative temperature is the average between the internal radiant temperature and the internal air temperature. For the concrete and the timber buildings, their operative temperature was taken from the building's fourth level offices zone.

Figure C.1 shows, for an average summer week, both the inside operative temperature (average between the radiant and the air temperatures) of the concrete building, and the summer outside dry-bulb temperature in Christchurch. Graph's gridlines are placed each $5^{\circ} \mathrm{C}$ within a range of temperatures that vary from $0^{\circ} \mathrm{C}$ to $35^{\circ} \mathrm{C}$. It can be seen that outside temperature varies significantly (up to $20^{\circ} \mathrm{C}$ variation) between day and night.

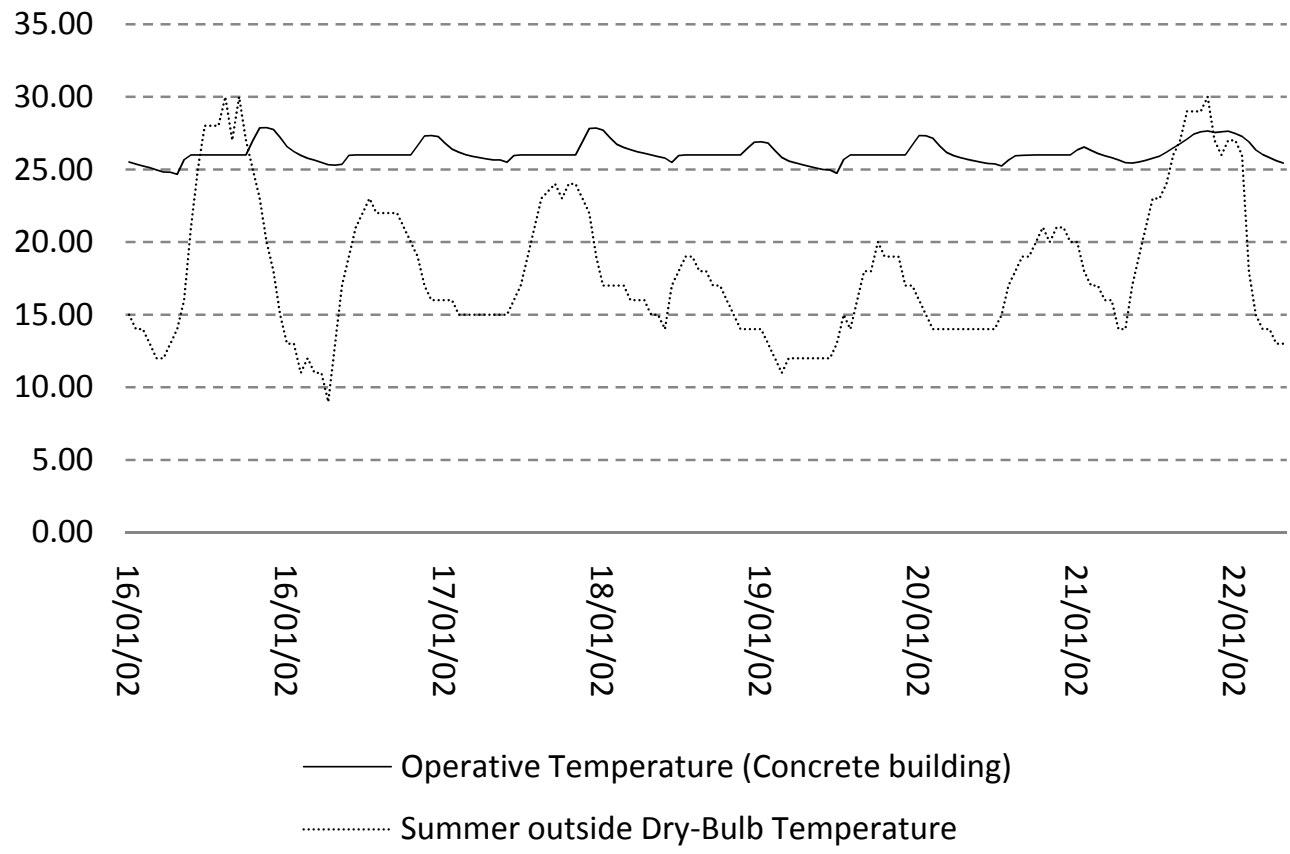

Figure C.1: Summer average week operative temperature of the concrete, steel and timber building (averaged) compared with outside Dry-Bulb temperature.

The highest temperature during the week was $30^{\circ} \mathrm{C}$ at $2 \mathrm{pm}$ on the $16^{\text {th }}$ of January and the lowest temperature was $9^{\circ} \mathrm{C}$ at $5 \mathrm{am}$ on the $17^{\text {th }}$ of January. The operative temperature inside the buildings remains stable within roughly $2^{\circ} \mathrm{C}$, with an average maximum of $27.5^{\circ} \mathrm{C}$ and minimum of $25.3^{\circ} \mathrm{C}$. 


\section{Appendixes}

Figure $\mathrm{C} .2$ shows, on a larger scale (each $0.5^{\circ} \mathrm{C}$ ), the summer internal operative temperature fluctuation between the concrete and timber buildings. Buildings internal temperatures in this graph are controlled by the HVAC-naturally ventilated system during office hours.

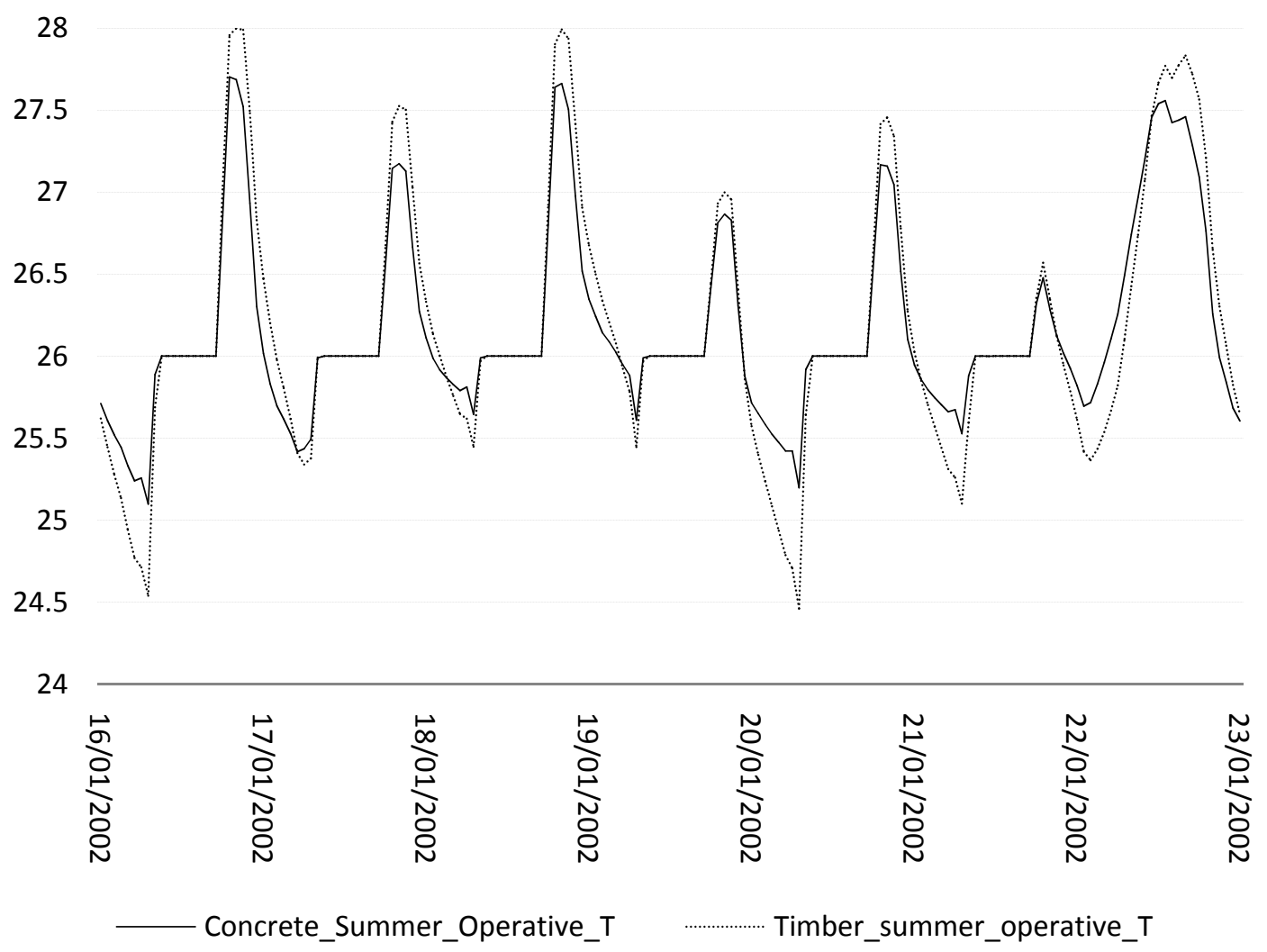

Figure C.2: Summer average week operative temperature in the concrete and timber building. 


\section{Appendixes}

Figure C. 3 shows, for average weeks in winter, both the inside operative temperature of the concrete building and the outside dry-bulb temperature in Christchurch.

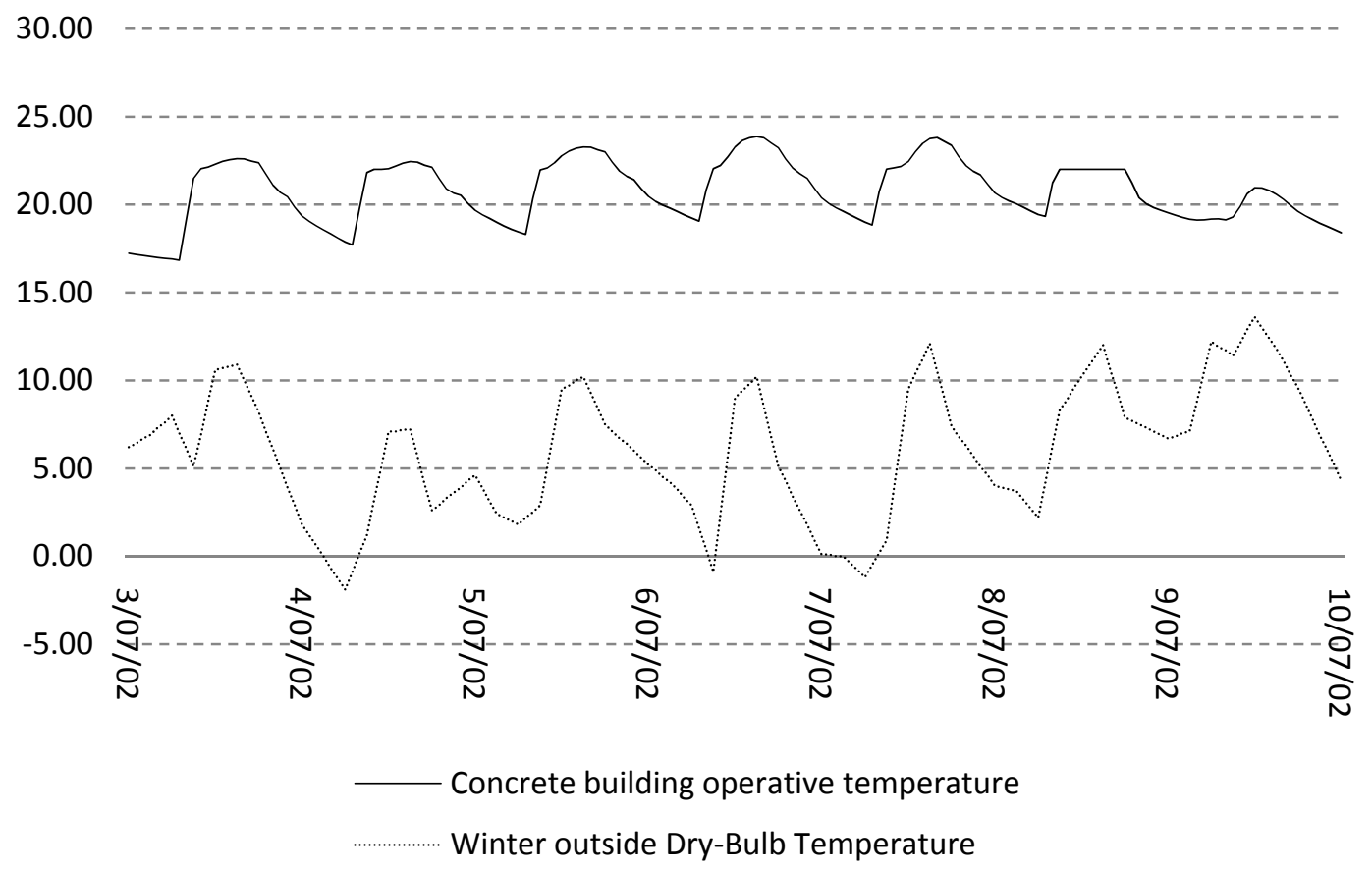

Figure C.3: Winter average week inside operative temperature of the concrete building compared with outside temperature.

It can be seen that outside temperatures vary up to $13^{\circ} \mathrm{C}$ between day and night. The highest temperature during the week was $14^{\circ} \mathrm{C}$ at midday on the $9^{\text {th }}$ of July and the lowest temperature was $-1.9^{\circ} \mathrm{C}$ at 6 am on the $4^{\text {th }}$ of July. The operative temperature inside the buildings remains stable, within roughly $5^{\circ} \mathrm{C}$, from an average maximum of $22.7^{\circ} \mathrm{C}$ and a minimum of $17.6^{\circ} \mathrm{C}$. 


\section{Appendixes}

Figure C. 4 shows, on a larger scale (each $0.5^{\circ} \mathrm{C}$ ), the winter internal operative temperature fluctuation between the concrete and the timber buildings. Offices' internal temperature in this graph is controlled by a heating system during office hours.

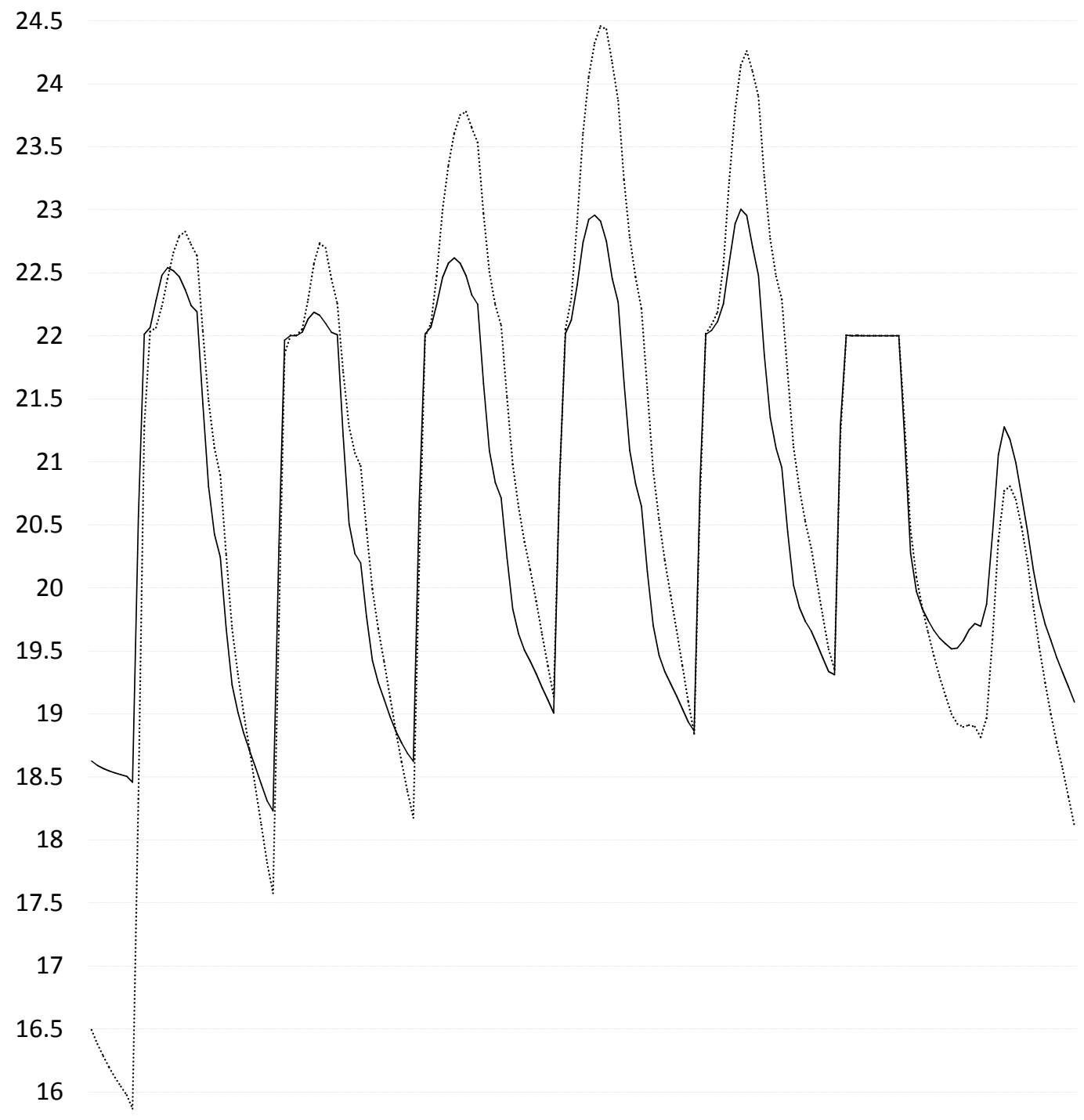

15.5

15

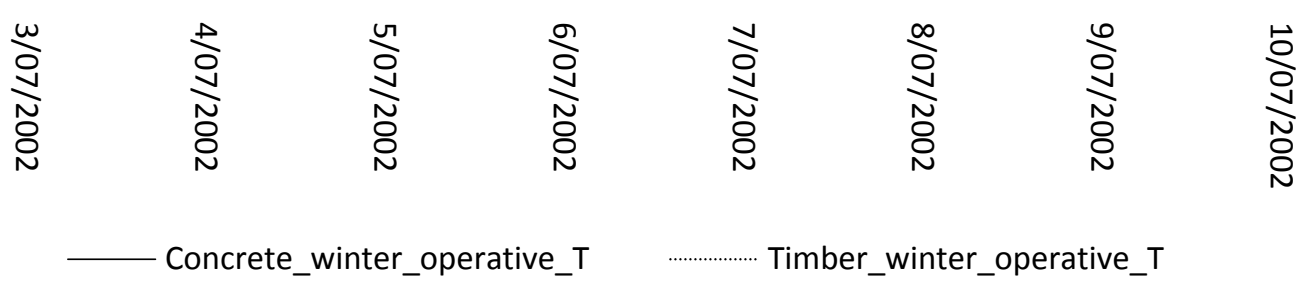

Figure C.4: Winter average week operative temperature in the concrete and timber buildings. 


\section{C.3 Operating $\mathrm{CO}_{2}$ emissions}

Total energy in Operation

$\mathrm{CO}_{2}$ emitted in operation

GJ

Tonnes / year

1 Concrete building

Total energy used, segregated in component

\begin{tabular}{|l|r|}
\hline Cooling & $115 \mathrm{GJ}$ \\
\hline Heating & $153 \mathrm{GJ}$ \\
\hline DHW & $51 \mathrm{GJ}$ \\
\hline System Misc (lift) & $45 \mathrm{GJ}$ \\
\hline Lighting & $433 \mathrm{GJ}$ \\
\hline Room Electricity & $272 \mathrm{GJ}$ \\
\hline Total: & $\mathbf{1 , 0 6 9} \mathbf{~ G J}$ \\
\hline
\end{tabular}

\begin{tabular}{|c|}
\hline 14 Tonnes/yr \\
\hline 9 Tonnes/yr \\
\hline 3 Tonnes/yr \\
\hline 6 Tonnes/yr \\
\hline 54 Tonnes/yr \\
\hline 34 Tonnes/yr \\
\hline 120 Tonnes/yr \\
\hline
\end{tabular}

2 Steel building

Total energy used, segregated in component

\begin{tabular}{|l|r|}
\hline Cooling & $141 \mathrm{GJ}$ \\
\hline Heating & $155 \mathrm{GJ}$ \\
\hline DHW & $51 \mathrm{GJ}$ \\
\hline System Misc (lift) & $45 \mathrm{GJ}$ \\
\hline Lighting & $433 \mathrm{GJ}$ \\
\hline Room electricity & $263 \mathrm{GJ}$ \\
\hline Total: & $\mathbf{1 , 0 8 9} \mathbf{~ G J}$ \\
\hline
\end{tabular}

\begin{tabular}{|c|}
\hline 18 Tonnes/yr \\
\hline 9 Tonnes/yr \\
\hline 3 Tonnes/yr \\
\hline 6 Tonnes/yr \\
\hline 54 Tonnes/yr \\
\hline 33 Tonnes/yr \\
\hline 123 Tonnes/yr \\
\hline
\end{tabular}

4 Timber building

Total energy used, segregated in component

\begin{tabular}{|l|r|}
\hline Cooling & 170 GJ \\
\hline Heating & 146 GJ \\
DHW & 51 GJ \\
\hline System Misc (lift) & 45 GJ \\
\hline Lighting & 433 GJ \\
\hline Room electricity & 275 GJ \\
\hline Total: & $\mathbf{1 , 1 2 1 ~ G J}$ \\
\hline
\end{tabular}

\begin{tabular}{|c|}
\hline 21 Tonnes/yr \\
\hline 9 Tonnes/yr \\
\hline 3 Tonnes/yr \\
\hline 6 Tonnes/yr \\
\hline 54 Tonnes/yr \\
\hline 34 Tonnes/yr \\
\hline 127 Tonnes/yr \\
\hline
\end{tabular}

3 Timber-Plus building

Total energy used, segregated in component

\begin{tabular}{|l|r|}
\hline Cooling & $134 \mathrm{GJ}$ \\
\hline Heating & $159 \mathrm{GJ}$ \\
\hline DHW & $51 \mathrm{GJ}$ \\
\hline System Misc (lift) & $45 \mathrm{GJ}$ \\
\hline Lighting & $433 \mathrm{GJ}$ \\
\hline Room electricity & $275 \mathrm{GJ}$ \\
\hline Total: & $\mathbf{1 , 0 9 7}$ GJ \\
\hline
\end{tabular}

\begin{tabular}{|c|}
\hline 17 Tonnes/yr \\
\hline 10 Tonnes/yr \\
\hline 3 Tonnes/yr \\
\hline 6 Tonnes/yr \\
\hline 54 Tonnes/yr \\
\hline 34 Tonnes/yr \\
\hline 124 Tonnes/yr \\
\hline
\end{tabular}

Table C.2: Operating $\mathrm{CO}_{2}$ emissions segregated into end-uses 


\section{Discussion}

\section{D.1 Total Life-Cycle Energy Consumption and $\mathrm{CO}_{2}$ emissions}

Table D.1 shows for the concrete, steel, timber and timber-plus buildings the 60 year life-cycle energy consumption and $\mathrm{CO}_{2}$ emissions. Results for embodied energy and $\mathrm{CO}_{2}$ emissions in table D.1 were produced using Alcorn coefficients.

\begin{tabular}{|c|c|c|c|c|c|c|}
\hline \multicolumn{3}{|c|}{$\begin{array}{l}\text { Operational energy } \\
\text { consumptio and } \\
\mathrm{CO}_{2} \text { emissions } \\
60 \text { years operations }\end{array}$} & \multicolumn{2}{|l|}{ EE and ECO2 } & \multicolumn{2}{|c|}{$\begin{array}{l}\text { Life-cycle energy } \\
\text { consumption and } \\
\mathrm{CO}_{2} \text { emissions }\end{array}$} \\
\hline \multicolumn{7}{|c|}{1 Concrete building } \\
\hline \multirow[t]{2}{*}{ Energy } & $64,138 \mathrm{GJ}$ & $76 \%$ & $19,768 \mathrm{GJ}$ & \multirow[t]{2}{*}{$24 \%$} & 83,906 GJ & $100 \%$ \\
\hline & $18.1 \mathrm{GJ} / \mathrm{m}^{2}$ & & $5.6 \mathrm{GJ} / \mathrm{m}^{2}$ & & $23.7 \mathrm{GJ} / \mathrm{m}^{2}$ & $8 \%$ \\
\hline \multirow[t]{2}{*}{$\mathrm{CO}_{2}$} & 7,239 Tonnes & \multirow[t]{2}{*}{$85 \%$} & 1,245 Tonnes & \multirow[t]{2}{*}{$15 \%$} & 8,484 Tonnes & $100 \%$ \\
\hline & $2.05 \mathrm{t} / \mathrm{m}^{2}$ & & $0.35 \mathrm{t} / \mathrm{m}^{2}$ & & $2.40 \mathrm{t} / \mathrm{m}^{2}$ & $22 \%$ \\
\hline \multicolumn{7}{|c|}{2 Steel building } \\
\hline \multirow[t]{2}{*}{ Energy } & $65,310 \mathrm{GJ}$ & \multirow[t]{2}{*}{$69 \%$} & $29,167 \mathrm{GJ}$ & \multirow[t]{2}{*}{$31 \%$} & $94,478 \mathrm{GJ}$ & $100 \%$ \\
\hline & $18.5 \mathrm{GJ} / \mathrm{m}^{2}$ & & $8.2 \mathrm{GJ} / \mathrm{m}^{2}$ & & $26.7 \mathrm{GJ} / \mathrm{m}^{2}$ & $22 \%$ \\
\hline \multirow[t]{2}{*}{$\mathrm{CO}_{2}$} & 7,377 Tonnes & \multirow[t]{2}{*}{$83 \%$} & 1,491 Tonnes & \multirow[t]{2}{*}{$17 \%$} & 8,868 Tonnes & $100 \%$ \\
\hline & $2.09 \mathrm{t} / \mathrm{m}^{2}$ & & $0.42 \mathrm{t} / \mathrm{m}^{2}$ & & $2.51 \mathrm{t} / \mathrm{m}^{2}$ & $27 \%$ \\
\hline \multicolumn{7}{|c|}{3 Timber building } \\
\hline \multirow[t]{2}{*}{ Energy } & $67,255 \mathrm{GJ}$ & \multirow[t]{2}{*}{$78 \%$} & 19,476 GJ & \multirow[t]{2}{*}{$22 \%$} & 86,731 GJ & $100 \%$ \\
\hline & $19.0 \mathrm{GJ} / \mathrm{m}^{2}$ & & $5.5 \mathrm{GJ} / \mathrm{m}^{2}$ & & $24.5 \mathrm{GJ} / \mathrm{m}^{2}$ & $12 \%$ \\
\hline \multirow[t]{2}{*}{$\mathrm{CO}_{2}$} & 7,654 Tonnes & \multirow[t]{2}{*}{$97 \%$} & 245 Tonnes & \multirow[t]{2}{*}{$3 \%$} & 7,899 Tonnes & $100 \%$ \\
\hline & $2.16 \mathrm{t} / \mathrm{m}^{2}$ & & $0.07 \mathrm{t} / \mathrm{m}^{2}$ & & $2.23 \mathrm{t} / \mathrm{m}^{2}$ & $13 \%$ \\
\hline \multicolumn{7}{|c|}{4 Timber-Plus building } \\
\hline \multirow[t]{2}{*}{ Energy } & $65,824 \mathrm{GJ}$ & \multirow[t]{2}{*}{$85 \%$} & $11,832 \mathrm{GJ}$ & \multirow[t]{2}{*}{$15 \%$} & $77,656 \mathrm{GJ}$ & $100 \%$ \\
\hline & $18.6 \mathrm{GJ} / \mathrm{m}^{2}$ & & $3.3 \mathrm{GJ} / \mathrm{m}^{2}$ & & $22.0 \mathrm{GJ} / \mathrm{m}^{2}$ & $0 \%$ \\
\hline \multirow[t]{2}{*}{$\mathrm{CO}_{2}$} & 7,426 Tonnes & \multirow[t]{2}{*}{$106 \%$} & -446 Tonnes & \multirow[t]{2}{*}{$-6 \%$} & 6,980 Tonnes & $100 \%$ \\
\hline & $2.10 \mathrm{t} / \mathrm{m}^{2}$ & & $-0.13 \mathrm{t} / \mathrm{m}^{2}$ & & $1.97 \mathrm{t} / \mathrm{m}^{2}$ & \\
\hline \multicolumn{5}{|c|}{ Coefficents used for Embodied energy and CO2 calculations: } & \multicolumn{2}{|c|}{ Alcorn $(1998,2003)$} \\
\hline Net letta & le area: & & & & 3,536 & $\mathrm{~m}^{2}$ \\
\hline
\end{tabular}

Table D.1: Life-cycle energy consumption and $\mathrm{CO}_{2}$ emissions using Alcorn coefficients 


\section{Appendixes}

Table D.2 shows for the concrete, steel, timber and timber-plus buildings the 60 year life-cycle energy consumption and $\mathrm{CO}_{2}$ emissions. Results for embodied energy and $\mathrm{CO}_{2}$ emissions in Table D.2 were produced using GaBi coefficients.

\section{Operational energy consumption and \\ CO2 emissions}

60 years operations
EE and ECO2

Initial $\mathrm{EE}$ and $\mathrm{ECO}_{2}$ plus

recurrent $\mathrm{EE}$ and $\mathrm{ECO}_{2}$

\section{Life-cycle energy consumption and \\ $\mathrm{CO}_{2}$ emissions}

Operational $\mathrm{E}$ and $\mathrm{CO}_{2}$ plus total $\mathrm{EE}$ and $\mathrm{ECO}_{2}$

1 Concrete building

\begin{tabular}{|c|c|c|c|c|c|c|}
\hline \multirow[t]{2}{*}{ Energy } & $64,138 \mathrm{GJ}$ & \multirow[t]{2}{*}{$80 \%$} & $15,765 \mathrm{GJ}$ & \multirow[t]{2}{*}{$20 \%$} & $79,903 \mathrm{GJ}$ & \multirow{2}{*}{$\begin{array}{r}100 \% \\
7 \%\end{array}$} \\
\hline & $18.1 \mathrm{GJ} / \mathrm{m}^{2}$ & & $4.5 \mathrm{GJ} / \mathrm{m}^{2}$ & & $22.6 \mathrm{GJ} / \mathrm{m}^{2}$ & \\
\hline \multirow[t]{2}{*}{$\mathrm{CO}_{2}$} & 7,239 Tonnes & \multirow[t]{2}{*}{$83 \%$} & 1,451 Tonnes & \multirow[t]{2}{*}{$17 \%$} & 8,690 Tonnes & 100 \\
\hline & $2.05 \mathrm{t} / \mathrm{m}^{2}$ & & $0.41 \mathrm{t} / \mathrm{m}^{2}$ & & $2.46 \mathrm{t} / \mathrm{m}^{2}$ & \\
\hline
\end{tabular}

2 Steel building

\begin{tabular}{|c|c|c|c|c|c|c|}
\hline \multirow[t]{2}{*}{ Energy } & $65,310 \mathrm{GJ}$ & \multirow[t]{2}{*}{$76 \%$} & $20,457 \mathrm{GJ}$ & \multirow[t]{2}{*}{$24 \%$} & 85,768 GJ & \multirow{2}{*}{$\begin{array}{r}100 \% \\
15 \%\end{array}$} \\
\hline & $18.5 \mathrm{GJ} / \mathrm{m}^{2}$ & & $5.8 \mathrm{GJ} / \mathrm{m}^{2}$ & & $24.3 \mathrm{GJ} / \mathrm{m}^{2}$ & \\
\hline \multirow[t]{2}{*}{$\mathrm{CO}_{2}$} & 7,377 Tonnes & \multirow[t]{2}{*}{$82 \%$} & 1,674 Tonnes & \multirow[t]{2}{*}{$18 \%$} & 9,052 Tonnes & \multirow{2}{*}{$\begin{array}{r}100 \% \\
7 \%\end{array}$} \\
\hline & $2.09 \mathrm{t} / \mathrm{m}^{2}$ & & $0.47 \mathrm{t} / \mathrm{m}^{2}$ & & $2.56 \mathrm{t} / \mathrm{m}^{2}$ & \\
\hline
\end{tabular}

3 Timber building

\begin{tabular}{|c|c|c|c|c|c|c|}
\hline \multirow[t]{2}{*}{ Energy } & $67,255 \mathrm{GJ}$ & \multirow[t]{2}{*}{$81 \%$} & $15,900 \mathrm{GJ}$ & \multirow[t]{2}{*}{$19 \%$} & $83,155 \mathrm{GJ}$ & \multirow{2}{*}{$\begin{array}{r}100 \% \\
12 \%\end{array}$} \\
\hline & $19.0 \mathrm{GJ} / \mathrm{m}^{2}$ & & $4.5 \mathrm{GJ} / \mathrm{m}^{2}$ & & $23.5 \mathrm{GJ} / \mathrm{m}^{2}$ & \\
\hline \multirow[t]{2}{*}{$\mathrm{CO}_{2}$} & 7,654 Tonnes & \multirow[t]{2}{*}{$83 \%$} & 1,528 Tonnes & \multirow[t]{2}{*}{$17 \%$} & 9,182 Tonnes & \multirow{2}{*}{$\begin{array}{r}100 \% \\
9 \%\end{array}$} \\
\hline & $2.16 \mathrm{t} / \mathrm{m}^{2}$ & & $0.43 \mathrm{t} / \mathrm{m}^{2}$ & & $2.60 \mathrm{t} / \mathrm{m}^{2}$ & \\
\hline
\end{tabular}

4 Timber-Plus building

\begin{tabular}{|c|c|c|c|c|c|c|}
\hline \multirow{2}{*}{ Energy } & 65,824 GJ & \multirow[t]{2}{*}{$88 \%$} & $8,685 \mathrm{GJ}$ & \multirow[t]{2}{*}{$12 \%$} & 74,509 GJ & \multirow{2}{*}{$\begin{array}{r}100 \% \\
0 \%\end{array}$} \\
\hline & $18.6 \mathrm{GJ} / \mathrm{m}^{2}$ & & $2.5 \mathrm{GJ} / \mathrm{m}^{2}$ & & $21.1 \mathrm{GJ} / \mathrm{m}^{2}$ & \\
\hline \multirow[t]{2}{*}{$\mathrm{CO}_{2}$} & 7,426 Tonnes & \multirow[t]{2}{*}{$88 \%$} & 1,021 Tonnes & \multirow[t]{2}{*}{$12 \%$} & 8,447 Tonnes & $100 \%$ \\
\hline & $2.10 \mathrm{t} / \mathrm{m}^{2}$ & & $0.29 \mathrm{t} / \mathrm{m}^{2}$ & & $2.39 \mathrm{t} / \mathrm{m}^{2}$ & $0 \%$ \\
\hline
\end{tabular}

Coefficents used for Embodied energy and $\mathrm{CO}_{2}$ calculations:

GaBi

Net usable area: $3,536 \mathrm{~m}^{2}$

Table D.2: Life-cycle energy consumption and $\mathrm{CO}_{2}$ emissions using $\mathrm{GaBi}$ coefficients 
Appendixes 